\title{
Analysis, Design and Rehabilitation of Structural Members with Timber and FRP
}

Venkat Dheeraj Gadi Reddy

Follow this and additional works at: https://researchrepository.wvu.edu/etd

\section{Recommended Citation}

Gadi Reddy, Venkat Dheeraj, "Analysis, Design and Rehabilitation of Structural Members with Timber and FRP" (2016). Graduate Theses, Dissertations, and Problem Reports. 5637.

https://researchrepository.wvu.edu/etd/5637

This Thesis is protected by copyright and/or related rights. It has been brought to you by the The Research Repository @ WVU with permission from the rights-holder(s). You are free to use this Thesis in any way that is permitted by the copyright and related rights legislation that applies to your use. For other uses you must obtain permission from the rights-holder(s) directly, unless additional rights are indicated by a Creative Commons license in the record and/ or on the work itself. This Thesis has been accepted for inclusion in WVU Graduate Theses, Dissertations, and Problem Reports collection by an authorized administrator of The Research Repository @ WVU. For more information, please contact researchrepository@mail.wvu.edu. 


\title{
Analysis, Design and Rehabilitation of Structural Members with Timber and FRP
}

\author{
Venkat Dheeraj Gadi Reddy \\ Thesis submitted to the \\ Benjamin M. Statler College of Engineering and Mineral Resource \\ at West Virginia University \\ in partial fulfillment of the requirements \\ for the degree of
}

\section{Master of Science \\ in \\ Civil Engineering}

\author{
P. V. Vijay, Ph.D., Chair \\ David B. DeVallance, Ph.D. \\ Hema J. Siriwardane, Ph.D. \\ Omar I. Abdul-Aziz, Ph.D. \\ Department of Civil and Environmental Engineering \\ Morgantown, West Virginia \\ 2016
}

Keywords: Timber, FRP, Pedestrian Bridge, Wrapping, Timber Piles, Timber Beams, Glued Timber Beams, FRP Deck, FEM Analysis, Resin Filler

Copyright Gadi Reddy Venkat Dheeraj 2016 


\begin{abstract}
Analysis and Design of a Pedestrian Bridge with Timber and FRP Structural Elements

\author{
Venkat Dheeraj Gadi Reddy \\ Department of Civil and Environmental Engineering, West Virginia University
}

Bridges have been an integral feature of the mountainous West Virginia landscape, carrying roads railways, and pedestrian traffic over creeks and rivers from early 1860 . The state of West Virginia has always been a home for well reputed timber bridges in the last two centuries including several pedestrian bridges. This research focuses on designing a covered pedestrian bridge by using a combination of traditional and advanced materials such as timber, steel, and FRP for a length of 104.0' over three spans. Following the design process, structurally feasible and an economical choice of deck and stringer sections will be selected. This research also evaluates the effectiveness of using carbon fiber and glass fiber reinforced polymers to reinforce the timber beams/stringers and piles used for bridge structural elements. Specimens representing an FRP bridge deck (48.0”x10.25"x3.5”) and glued timber stringers (4”x10"x12' and 4"x12"x16') are tested under four-point bending. For timber elements, feasibility of using circular timber pile sections strengthened with FRP wraps are also investigated. Experimental results of decks, stringers, and pile elements are compared with theoretical and FE values and a good correlation is observed.
\end{abstract}




\section{ACKNOWLEDGEMENTS}

Firstly, I would like to express my gratitude to my academic advisor Dr. P. V. Vijay for giving me an opportunity to pursue Master of Science in Civil Engineering and for guiding me through complications of research.

I would also like to thank Dr. Hema J. Siriwardane, Dr. David B. DeVallance and Omar I. Abdul-Aziz, for agreeing to serve on my thesis committee.

Furthermore, I would also thank Jerry Nestor for helping me setup and conduct experiments, helping me get familiar with the lab equipment.

I would also like to thank Praveen and Piyush for their valuable suggestions and support right from the beginning. I would also thank my friends John Harper, Anudeep, Venkatesh, Krishna Tulasi, Kaushik, Pavan, Bhanoday, Praneeth, Anvesh, Vikram who have helped me with the experimental work when ever needed.

I also take this opportunity to thank my parents and family for being with me and encouraging me throughout. Without their encouragement this would not be possible. 


\section{Table of Contents}

\section{Contents}

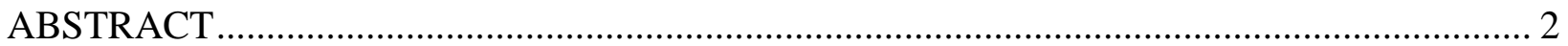

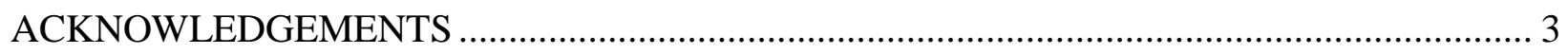

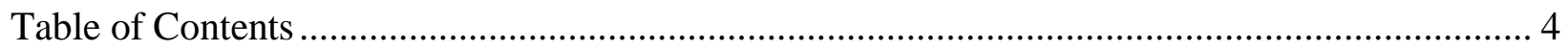

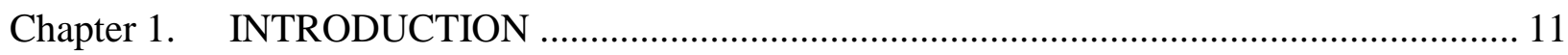

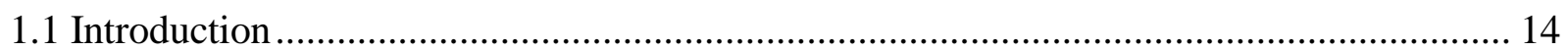

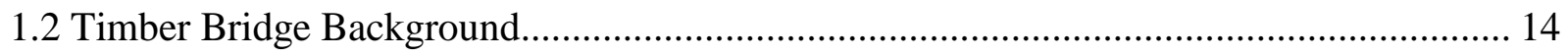

1.3 FRP Bridge Background …………………………................................................. 16

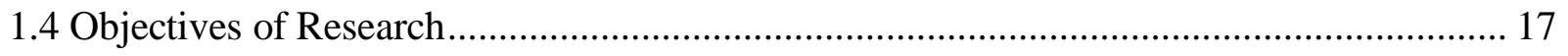

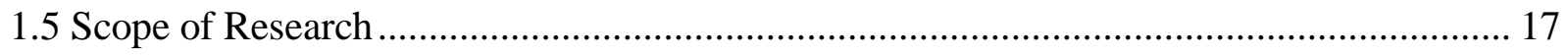

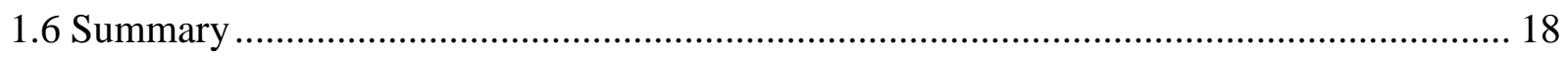

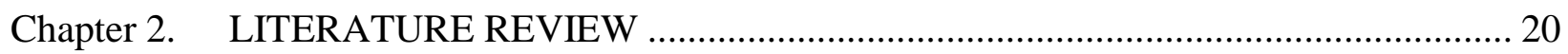

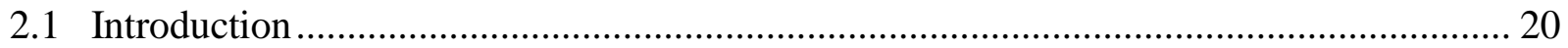

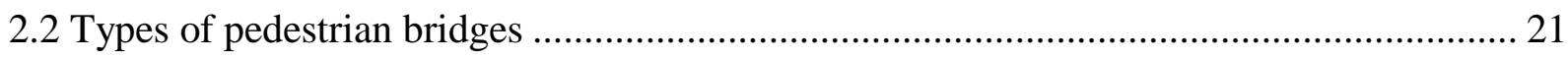

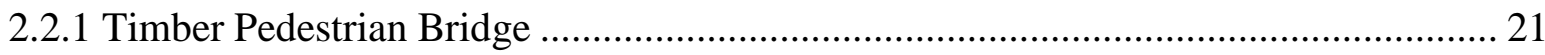

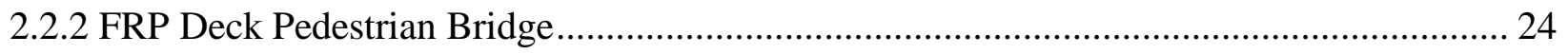

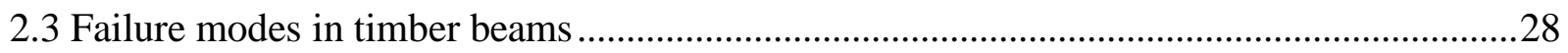

2.6 Timber beams strengthened with FRP in flexure and shear............................................. 32

2.5 Confinement effect of FRP on timber poles.................................................................... 36 


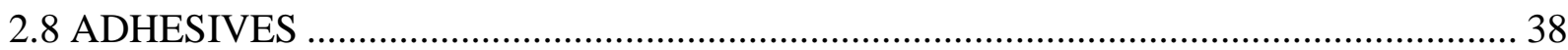

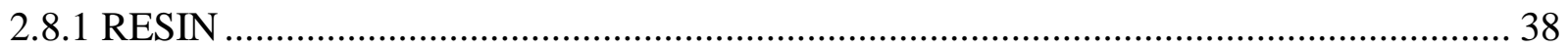

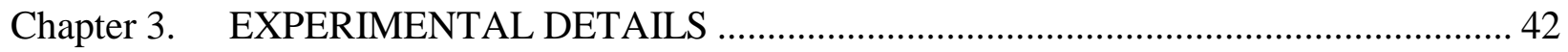

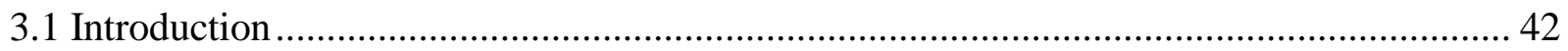

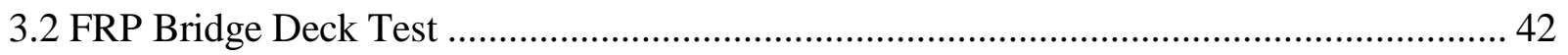

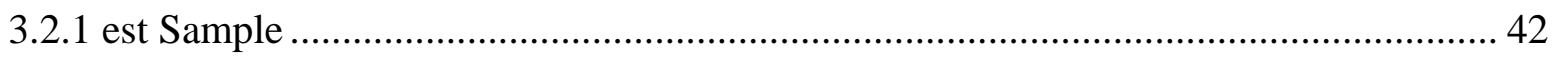

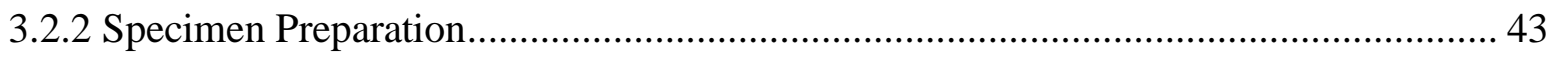

3.2.3 Test Set-up and Test Procedure............................................................................ 43

3.3 Coupon Tension Test ……………………………................................................. 44

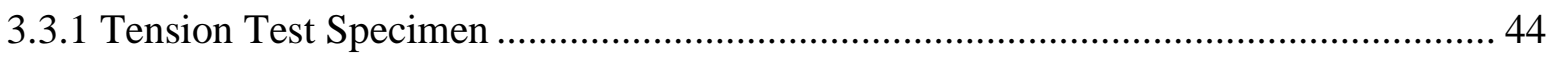

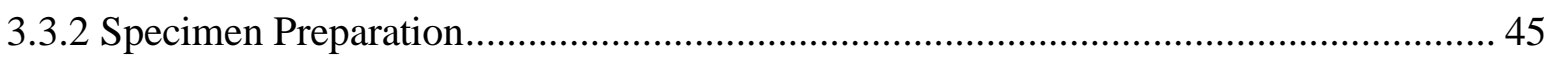

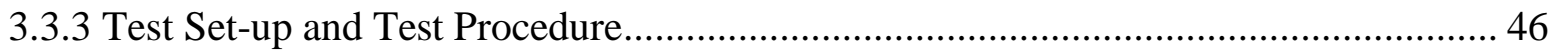

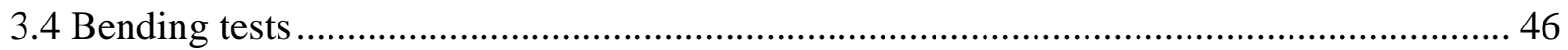

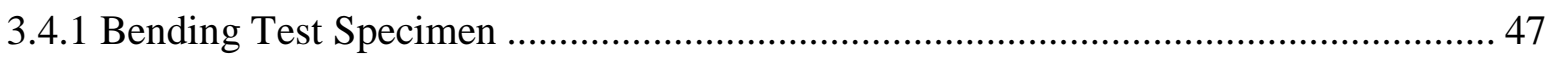

3.4.2 Coupon and Deck0 Bending Specimen Preparation. .................................................... 47

3.4.3 Coupon Bending Test Set-up and Test Procedure .................................................... 48

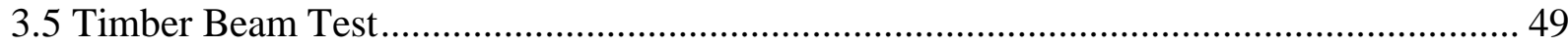

3.5.1 Beam Test Specimen.............................................................................................. 49

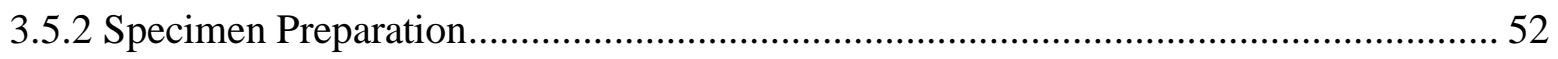


3.5.3 Test Set-up and Test procedure.

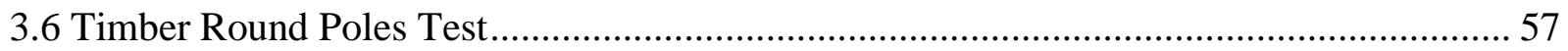

3.6.1 Test Sample

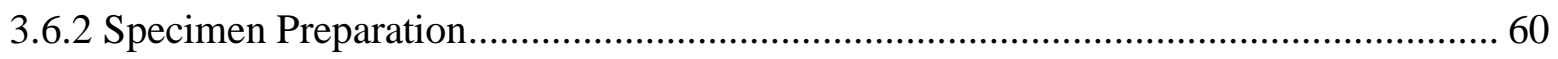

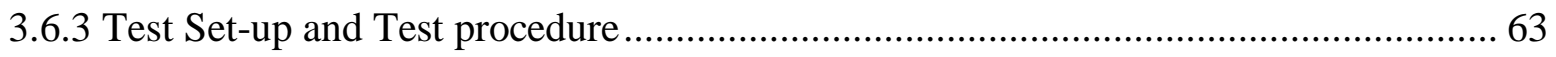

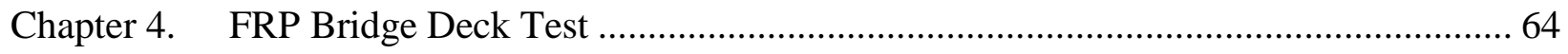

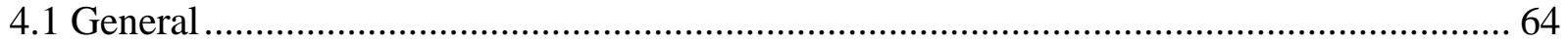

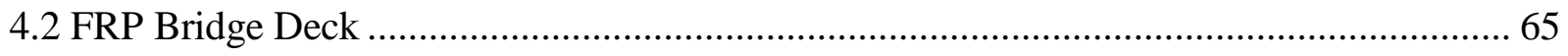

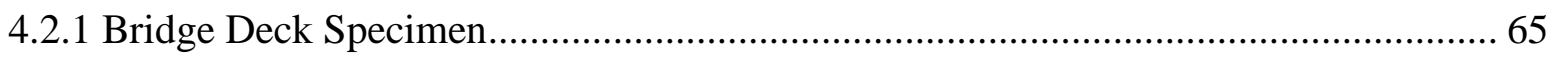

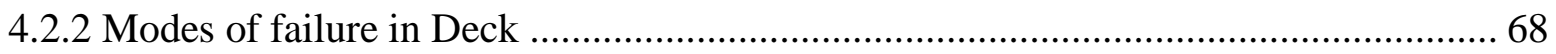

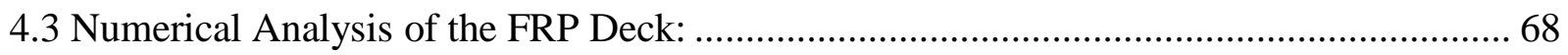

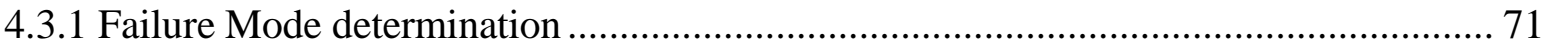

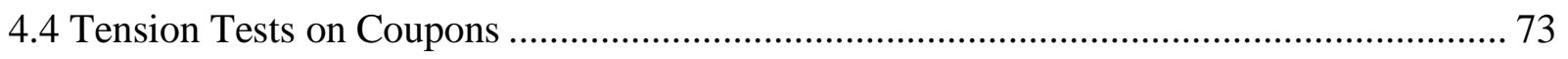

4.4.1 Longitudinal Coupons ............................................................................................... 73

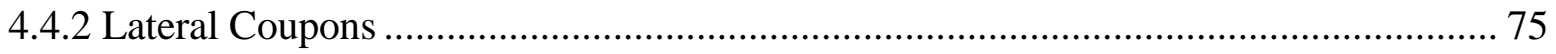

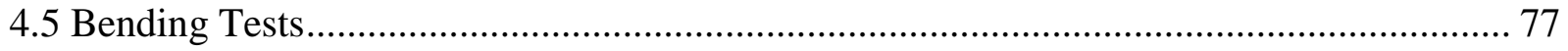

4.5.1 Bending Tests on Cross-Section Sample of Bridge Deck ............................................ 78

Chapter 5. AXIAL COMPRESSION TESTING OF FRP STRENGTHENED TIMBER CYLINDERS 80

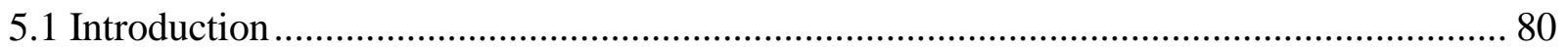


5.2.1 Effect of No. of CFRP Wrap Layers on Compression of Solid Timber Specimens..... 80

5.2.2 Effect of Section Loss on Compressive Strength of Timber Samples. 83

5.2.3 ffect of Wrap Layers on 2.0-inch Core-Filled Timber Specimens ............................ 85

5.2.4 Effect of Wrap Layers on Compression of 3.0-inch Core-Filled Cylinders ................ 87

5.2.5 Effect of FRP Wrapping on Solid and Core-filled Cylinders ................................. 90

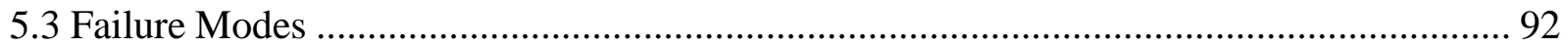

5.3.1 Non Wrapped Timber Cylinders ................................................................. 92

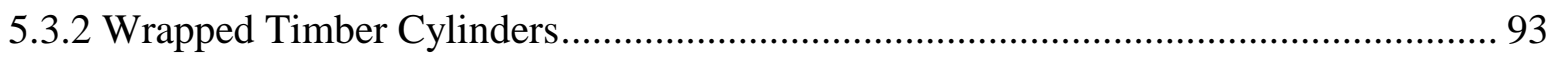

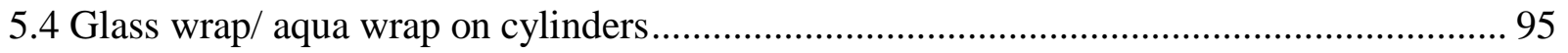

5.4.1 Effect of GFRP Wrap Layers on Compressive Strength of Solid Timber Specimens 95

5.4.2 Effect of GFRP Wrap Layers on 2.0” Hollow and Core Filled Timber Specimens.... 96

5.4.3 Effect of GFRP Wrap Layers on Compressive Strength of 2.0" Hollow Timber

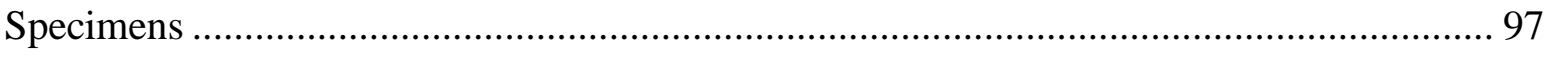

5.4.4 Effect of GFRP Wrap Layers on Compressive Strength of Solid, 2.0" Filled Timber

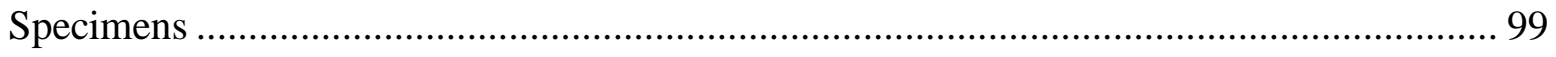

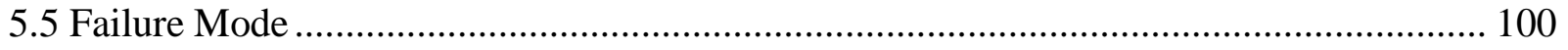

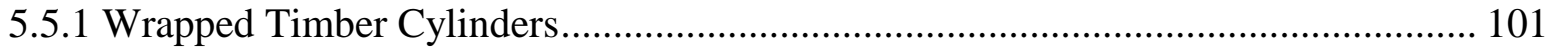

5.6 Comparison of CFRP Vs GFRP.................................................................. 102 
5.6.1 Effect of CFRP \& GFRP Wrap (2 layers) on Compressive Strength of Solid Timber Cylinders 102

5.6.2 Effect of CFRP \& GFRP Wrap (2 layers) on 2.0" Core Filled Timber Cylinders ..... 103

5.7 Theoretical Analysis of Confinement for Timber Cylinders.............................................. 104

Chapter 6. FLEXURAL TESTING OF FRP STRENGTHENED TIMBER BEAMS 107

6.1 Introduction 107

6.2 Results of Non-Glued and Glued Timber Beam Tests 107

6.2.1 Flexural Testing of Board B- 2 x 10 107

6.2.2 Flexural Testing of Glued B -2, 2 x 10 Beam With and Without FRP. 110

6.2.3 Flexural testing of glued B $-3,2 \times 10$ beam with and without FRP 113

6.2.4 Flexural testing of glued $\mathrm{B}-2,2 \times 12$ beam with and without FRP 115

6.3 Results on solid timber beams .116

6.3.1 Flexural testing of Solid beams with and without FRP 117

6.3.2 Flexural testing of Solid $6 \times 6$ beam with and without FRP 120

6.4 Analytical Models for strength of timber. 124

Chapter 7. Timber Bridge Design with Steel Girders 130

7.1 Introduction 130

7.2 Design Problem 131

7.2.1 Specification(s) 131

7.2.2 Materials 131 


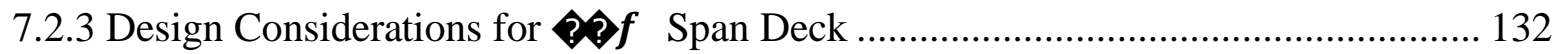

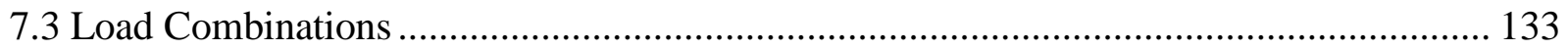

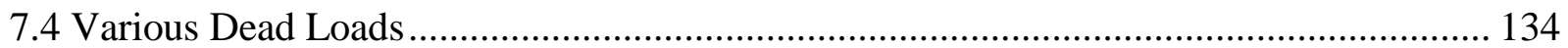

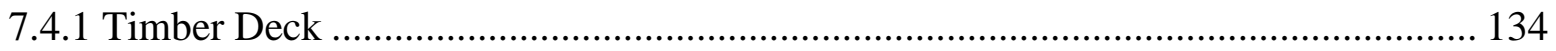

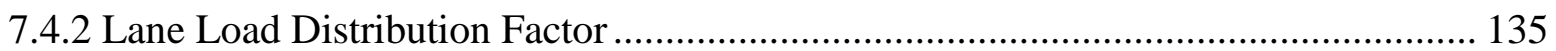

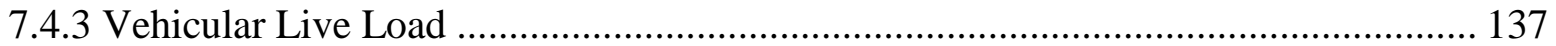

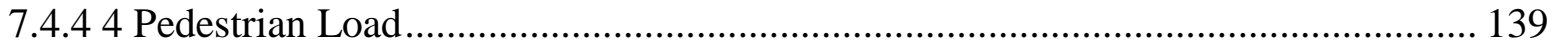

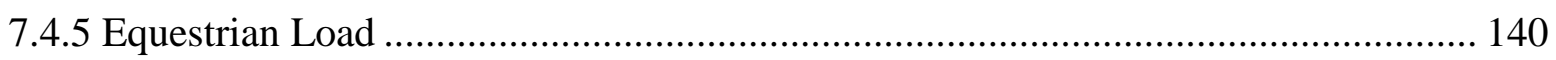

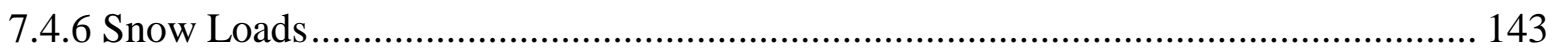

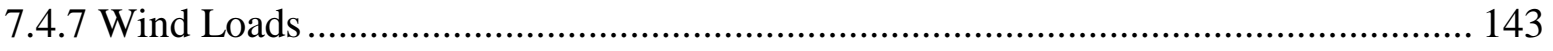

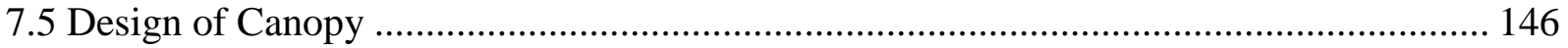

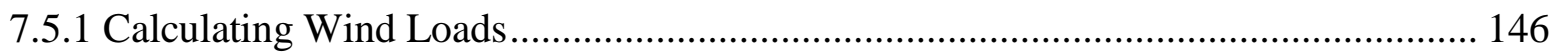

7.5.2 Wind and Snow Load on the Canopy .................................................................. 147

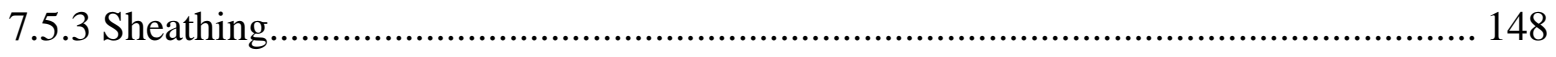

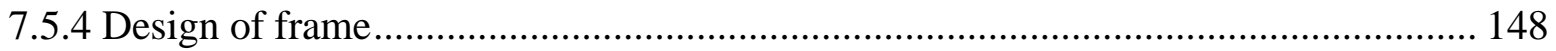

7.5.5 Design Posts ...................................................................................................... 149

7.5.6 Check for Load bearing Capacity of the Deck …………......................................... 151

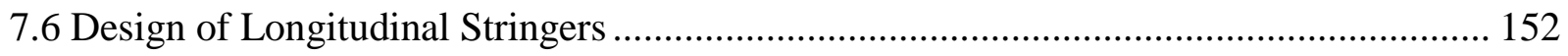

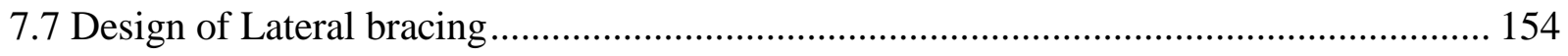

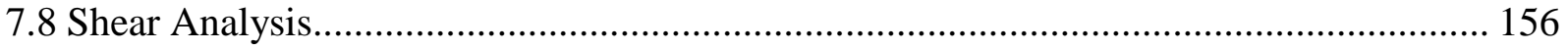


7.9 Serviceability Check on the Bridge Deck

7.10 Alternate Design of Timber/Glulam Stringers for Steel Stringers .............................. 161

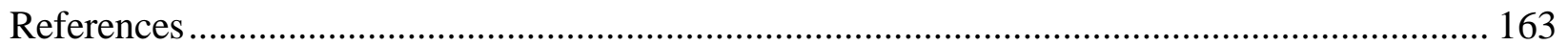




\section{Table of Contents}

\section{List of Figures}

Figure 1.2: Tension Parallel to grain and perpendicular to grain (Ritter, 1990)

23

Figure 2.6: Tensile Stress-Strain Behavior of Reinforcing Fibers as Compared With Steel and

Various Construction Materials (Gerriste, 1986) (Ambrose, 1993) ......................................... 25

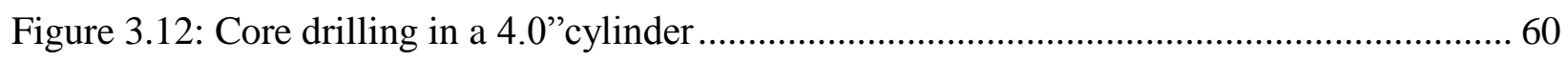

Figure 3.13: On left is a mixture of Hetron-D, MEKP, Cobalt Napthenate and left is a mixed resin

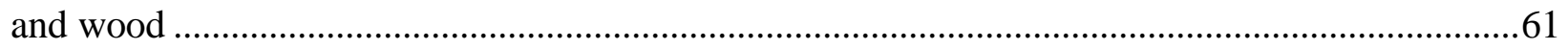

Figure 4.15: Wrapping of timber cylinders with Carbon and Glass FRP ....................................63

Figure 4.1: Load Vs Deflection plot for FRP bridge deck test in 3 point bending ...................... 66

Figure 1.17: Failure modes in timber cylinders with GFRP wrap and various configurations 101 


\section{List of Tables}

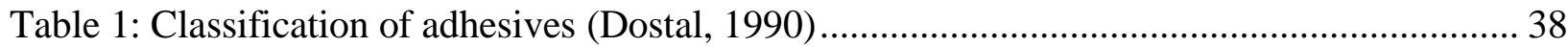

Table 2: Thermoplastic resins with advantages and disadvantages (Dostal, 1990).................... 39

Table 3: Thermosetting resins with advantages and disadvantages (Dostal, 1990) .................... 39

Table 3.1: Detailed dimensions of the FRP deck sample ................................................... 42

Table 3.2: Details of coupons tested in tension (ASTM D 3039/D 3039M) ............................ 46 


\section{Chapter 1. INTRODUCTION}

\subsection{Introduction}

The evolution of bridge technology in United States begins with colonial carpenters and masons building mostly short-span bridges of timber or stone. During 18th century, long span wood truss bridges (trestle bridges) often covered with siding and a roof to protect the load-carrying trusses were built (Ritter, 1990). The beginning of Industrial revolution in $19^{\text {th }}$ century required the construction of transportation infrastructure and an increase in usage of timber as a primary construction material. Wood design methodologies, lamination, preservative treatments, etc. are some of the major technological advances related to timber usage in the 20th century (Ritter, 1990). This research work deals with the use of timber and fiber reinforced polymer (FRP) for design and construction of bridges including repair of bridge column and beam elements. Specifically, a pedestrian bridge has been designed to be built at Jackson Mill, West Virginia using timber, FRP, and steel materials.

\subsection{Timber Bridge Background}

Bridge is a structure which serves a connection or passage over a gap without blocking the opening or passage way beneath. Timber Bridges have been the major mode of transport across streams, rivers, creeks and valleys, roads and railways for decades before getting replaced by present day materials like steel, reinforced concrete, and FRPs. The concept of bridges initiated with the use of timber as the construction material as it was the only predominant naturally available and renewable material readily available during those times when steel and concrete were non-existent or slowly coming into existence. Powder Point Bridge in Duxbury, Massachusetts holds its name in Guinness book of world records for being the oldest and longest timber bridge. Bridges are 
constructed over oceans, connecting various islands and one such example is Lake Pontchartrain Causeway (126,122 ft.) in New Orleans, Louisiana.

Bridges can be classified based on various criteria such as types of deck or beam, support conditions, span, prestress and materials. Some of the truss type bridges are Deck type, through type, Pony type, King post, Queen post, Howe truss, Burr arch truss, Pratt truss, Camel back, and Warren truss etc. ASCE (American Society of Civil Engineers, 2013) survey report declared that there are 607,380 bridges in United States and 1 out of 9 are structurally deficient. The average life of each bridge is calibrated to be about 42 years.

Timber's wide spread availability since ancient times and the resilience acquired from its orthotropic nature (anisotropic) to certain types of loading and atmospheric exposure gives it an edge over certain other materials. Historically, timber has been the primary material for bridges, but slowly replaced by iron, steel, and concrete in the late 19th and early 20th centuries. However, timber has continued to stand up to the challenges in constructing buildings and bridges on secondary and low-volume roads.

The state of West Virginia is full of roads and railways over creeks and rivers. In the highway system alone there are more than 6,300 bridges, and there are many private pedestrian and auto bridges, as well as railroad bridges. The oldest bridge in West Virginia is the Elk Grove Stone Arch Bridge, constructed in 1817 and also known as the Monument Place Bridge. Most familiar are the covered bridges, which were roofed and sided as protection against the weather. The covered bridge era spanned between 19 th and early $20^{\text {th }}$ century in West Virginia. The most famous of all of West Virginia's historic bridges is the 1849, Wheeling Suspension Bridge and West Virginia's best-known bridge of modern times is the steel arch New River Gorge Bridge (1977) on U.S. 19 in Fayette County. 


\subsection{FRP Bridge Background}

A fiber reinforced polymer (FRP) composite consists of a combination of polymer matrix (thermoplastic or thermosetting resin) and reinforcing element such as glass, carbon, basalt, and aramid (Ehlen, 1999). The use of FRP in pedestrian and vehicular bridges in USA has been the subject of increasing research and development since the late 1980's. However, aircraft and aerospace industries have been extensively utilizing the FRPs since 1960's. Encouraged by growing acceptance of advanced composite materials in the sporting industries and the potential for corrosion resistance, the Federal Highway Administration (FWHA) and the National Science Foundation (NSF) in late 1980's began increasing funding to enable research on FRP materials for infrastructure applications. Much of the focus was on bridges as highway bridge deterioration in the USA in the mid-1980s was regarded as a pressing national concern (Bank, 2006).

In 1986, the world's first highway bridge using composite reinforcing tendons was built in Germany (Sahirman S. C., 2003). The first, all composites pedestrian bridge was installed in 1992 in Aberfeldy, Scotland (Sahirman S. C., 2003). In the U.S., the first FRP reinforced concrete bridge deck was built in 1996 at McKinleyVille, WV followed by the first all-composite vehicular bridge deck in Russell, KS (Sahirman S. C., 2003).

FRP is been extensively used and grabbed the attention of the bridge and construction (rehabilitation) industry due to several of its advantageous properties. Some of the advantages of FRPs include high specific-strength, specific-stiffness, high resistance to corrosion, ability to withstand extreme temperatures and exposure conditions (Sahirman, Creese, GangaRao, \& Brown, 2003). Other advantages in the use of composites include the ease of manufacturing, fabrication, handling, and erection, which can result in short project delivery and completion time. 


\subsection{Objectives of Research}

The following objectives will be met through this research work:

1. Designing of a timber pedestrian bridge in Jackson Mill, West Virginia.

2. Understanding the behavior of FRP composite deck system used in lieu of timber decks for pedestrian bridges.

3. To study the use of FRP composite wraps in the rehabilitation and strengthening of timber structural elements with FRP wraps for enhancing axial and bending strengths.

\subsection{Scope of Research}

- A pedestrian timber bridge is designed in accordance with AASHTO 2012

- Alternative FRP decking evaluated in the lab.

- Timber cylinders with various configurations i.e. (solid, core drilled, core filled, wrapped with 1, 2 and 3 layers) are tested in axial compression.

- Effect of FRP wrap confinement on regular and repaired timber cylinders with section loss are evaluated.

- Glued timber boards bonding and solid timber beams are evaluated with and without FRP fabric. 


\subsection{Summary}

Chapter 1: This chapter covers introduction on bridges, background on timber and FRP bridges, objectives in this research and scope

Chapter 2: This chapter deals with various literature review by other researchers on timber and FRP structural elements in a bridge.

Chapter 3: Describes experimental test set-up and materials used in this work for testing FRP bridge deck, FRP wrapped cylinders and beams.

Chapter 4: Describes the testing of FRP bridge deck specimen and its elements and its structural behavior.

Chapter 5: This chapter deals with timber cylinders and strengthening of cylinders using CFRP Chapter 6: Describes the flexural behavior of solid and glued timber beams in 4 point bending with and without CFRP.

Chapter 7: This chapter contains design of a covered pedestrian timber bridge with steel and timber stringers

Concrete bridge decks were replaced by FRP decks in mid-1980s and FRP girder came into existence in mid-1990s. FRP bridge components have been typically designed for HS20-44 highway loads according to the AASHTO Standard Specification for Highway Bridges (Bank, 2006). The standard truck weight of this loading is 36 Ton with an allowable deflection limit of L/800 for both girder and deck (AASHTO, AASHTO LRFD Bridge Design Specifications, 2012). In 1996 Kansas Structural Composites developed a molded sandwich panel with a honeycomb FRP core which is installed in a 7.0 meter long slab-bridge (no girders) in Russell County, Kansas (Bank, 2006). The same system was also used in 8.0-meter-long bridge in Missouri in 2000 (The St. James bridge). In 2004, a very-large, double-layer, glass-vinyl ester FRP grid reinforcing 
system was used in a $40 \mathrm{~m}$ long ( $2 \mathrm{~m}$ girder spacing) pre-stressed concrete girder bridge on State Highway 151 in Fond du Lac, Wisconsin (Bank, 2006). In 2001, a hybrid carbon shell (tube) girder developed at the University of California San Diego in the mid-1990s was used to support two 10 m long spans (2.4 m girder spacing) of the Kings Storms water Channel Bridge on State Route 86 in Riverside County, California (Bank, 2006). 


\section{Chapter 2. LITERATURE REVIEW}

\subsection{Introduction}

Pedestrian bridges facilitate the crossing of streams, valleys or creeks by humans. Pedestrian bridges are predominantly intended for human usage but in remote places like forests and woods, they are also used by wildlife and small vehicles. Load Resistance Factor Design (LRFD) specifications highly recommend and emphasize on consideration of Equestrian loads on pedestrian bridges irrespective of the location of the bridge.

Many early forms of pedestrian bridges were provided to cross limited-access highways in areas that were built up and lacked intersection. Cities such as Las Vegas, Nevada have installed pedestrian bridges at major intersections along the Las Vegas strip, to reduce traffic congestions and improve pedestrian safety.

A covered bridge is a timber-truss bridge with a roof and siding which, in most covered bridges, create an almost complete enclosure. The purpose of covering is to protect wooden structural members from adverse weather as compared to some of the uncovered bridges in history having a life span of only 10 to 15 years. As many as 12,000 covered bridges existed in the United States during early $20^{\text {th }}$ century but later on dropped to under 1500 by 1950's. Philippi covered bridge on Tygart Valley River by far is the longest covered bridge within the state of West Virginia with a length of $285 \mathrm{ft}(87 \mathrm{~m})$ which is also a main local land mark and historical icon.

Replacing the conventional constructional materials, FRP has started new era in the history of bridges and construction industry. There are over 300 FRP-pedestrian bridges and 50 highway bridges with FRP decks or girders in the USA (Bank, 2006). In addition, there are handful of hybrid FRP and concrete bridges that have been built over the years. FRP wraps have been extensively used for rehabilitation of concrete bridges by late 1990's and early 2000's. West Virginia 
University have worked extensively in developing models to evaluate FRP decks under Shear loads, predict fatigue life of hybrid composites, and long term creep behavior of polymers. Similarly, other academic institutions such as the University of Missouri-Rolla have installed the first fully composite bridge in Missouri was installed on their campus.

\subsection{Types of pedestrian bridges}

Pedestrian bridges comprising of timber, concrete, and FRP decks are reviewed in this section.

\subsubsection{Timber Pedestrian Bridge}

Timber bridges have several basic types namely (1) Trestle, (2) longitudinal deck, (3) longitudinal stress laminated, (4) girder, (5) truss, and (6) arch.

Timber bridges have glue-laminated timber or lumber as deck material and several structural properties like stress, strain and deflection depend on direction of applied load being parallel or perpendicular to the grain. Natural growth characteristics such as knots, slope of grain, and shakes might have adverse effect on the structural functioning and properties of wood.

Moisture content and shrinkage are few properties which mainly control the structural performance of the member. Shrinkage of wood is the highest in a direction tangent to the annual rings, followed by radial and longitudinal directions.

Glulam decks are strong, exhibit high stiffness, and act watertight because of the homogenous bond between laminations and dispersion of strength reducing characteristics. Its improved stiffness allows it to provide a firm base for asphalt pavement, which is mostly used as a wearing surface. 


\subsubsection{Modes of failure}

Compression: Timber used as a deck material can be subjected to compression parallel to grain, perpendicular to grain or at an angle. When compression is applied parallel to grain direction, stress deforms the wood cells along their longitudinal axis. At ultimate loads, large deformations occur due to internal crushing of cellular structure. Likewise, compression perpendicular to grain produces strain that deforms cells perpendicular to their length. It is evident that wood cells tend to fail at relative low stress levels in the latter case resulting in loss in utility way before failure.

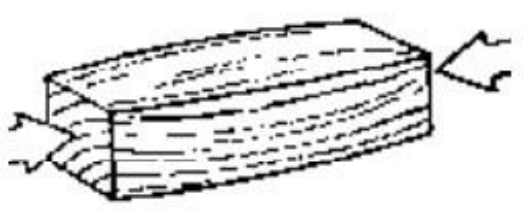

Compression parallel to grain

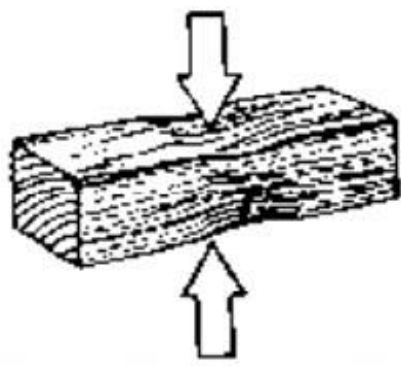

Compression perpendicular to grain

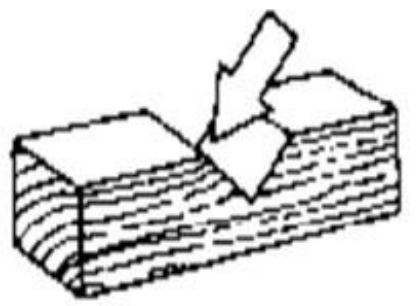

Compression at an angle

Figure 2.1: Compression in wood members (Ritter, 1990)

Tension: Wood is relatively strong in tension when loaded parallel to grain. Failure in this case occurs by combined effect of two modes i.e. cell to cell slippage and cell wall failure (rupture with in the cell wall) and there is very little or no visible deformation prior to complete deformation. In contrast, wood is weak in tension perpendicular to grain and causes splitting and cleavage along the grain that significantly affects the structural integrity. 

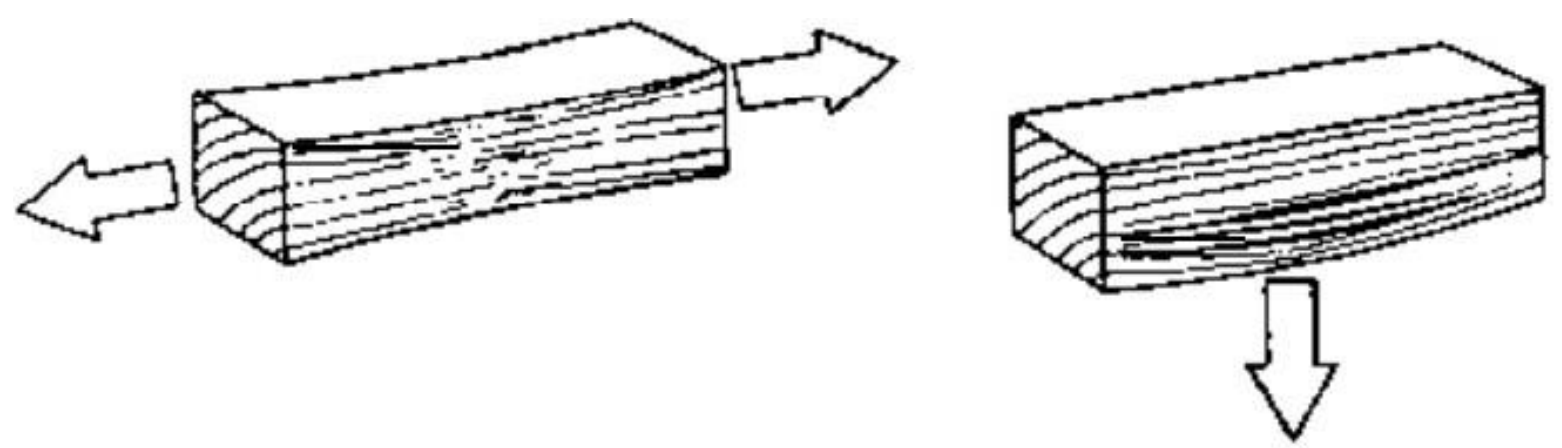

Figure 1.2: Tension Parallel to grain and perpendicular to grain (Ritter, 1990)

Shear: There are 3 types of shear namely vertical, horizontal and rolling. Among these, horizontal is more predominant. Vertical shear is dominated by failures like compression perpendicular to grain. In horizontal shear, the upper portion slides over the underneath ones by breaking intercellular bonds and deforming the wood cell structure.

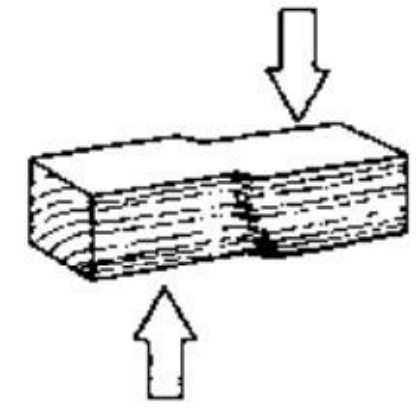

Vertical

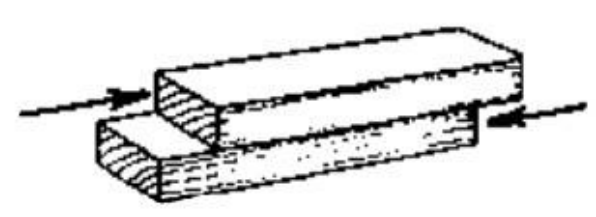

Horizontal

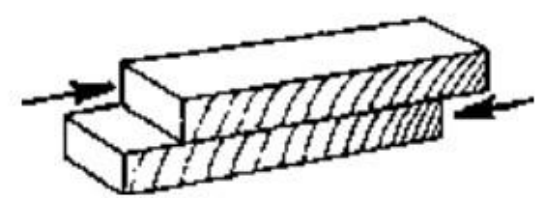

Rolling

Figure 2.3: Shear in wood members (Ritter, 1990)

Rolling shear is caused by loads acting perpendicular to the cell length in a plane parallel with the grain. Wood has low resistance to rolling shear and the failure is usually preceded by large deformations in the cross sections of cell.

Bending: Bending in wood failure modes are show in the Fig. 2.4. 


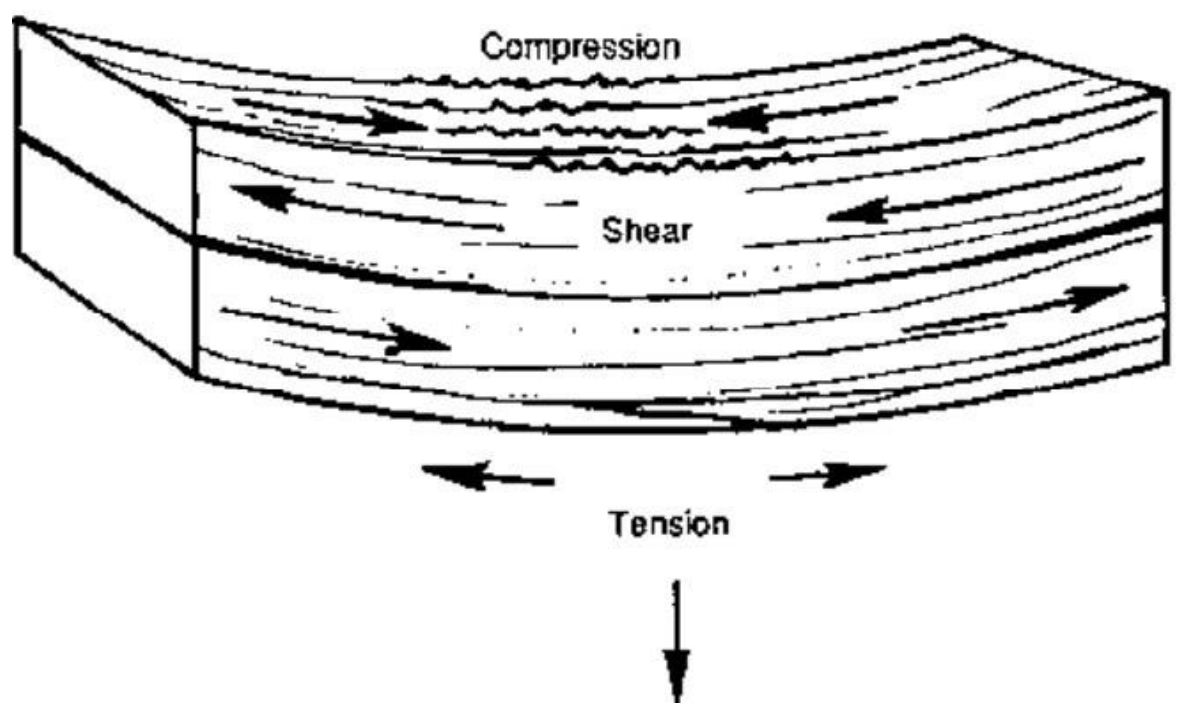

Figure 2.4: Bending in wood produces tension and compression in the extreme fibers, horizontal shear and vertical deflection (Ritter, 1990)

Torsion: Very little literature is available on mechanical properties of wood in torsion and is not a major factor in timber design.

Shock Resistance: Timber quickly absorbs and dissipates the energy by deformations. Wood is highly resilient to shocks and best preferred in such conditions.

\subsubsection{FRP Deck Pedestrian Bridge:}

Fiber reinforced polymers (FRP) can be used along with other traditional materials in the construction of bridge decks. Mechanical properties of the composites depend on many variables such as fiber types, fiber orientations, fiber-volume fraction, and fiber/fabric architecture. The fiber is the critical constituent which carries most of the load in composites, and occupies 30-70\% of the composite matrix volume.

Deterioration of concrete decks is one of the most common problems in composite (steel-concrete) bridges which can be effectively resisted by FRP wrapping. 
Concrete bridge decks reinforced with FRP bars have also been implemented in the US, Canada and other countries during last two decades. Unlike steel, tensile strength of FRP bars is a function of diameter. Shear lag causes outer diameter fibers to experience more stress than fibers on the inside of the cross-section which infers that FRP is an orthotropic material and exhibit high tensile strength in the primary direction of fibers.
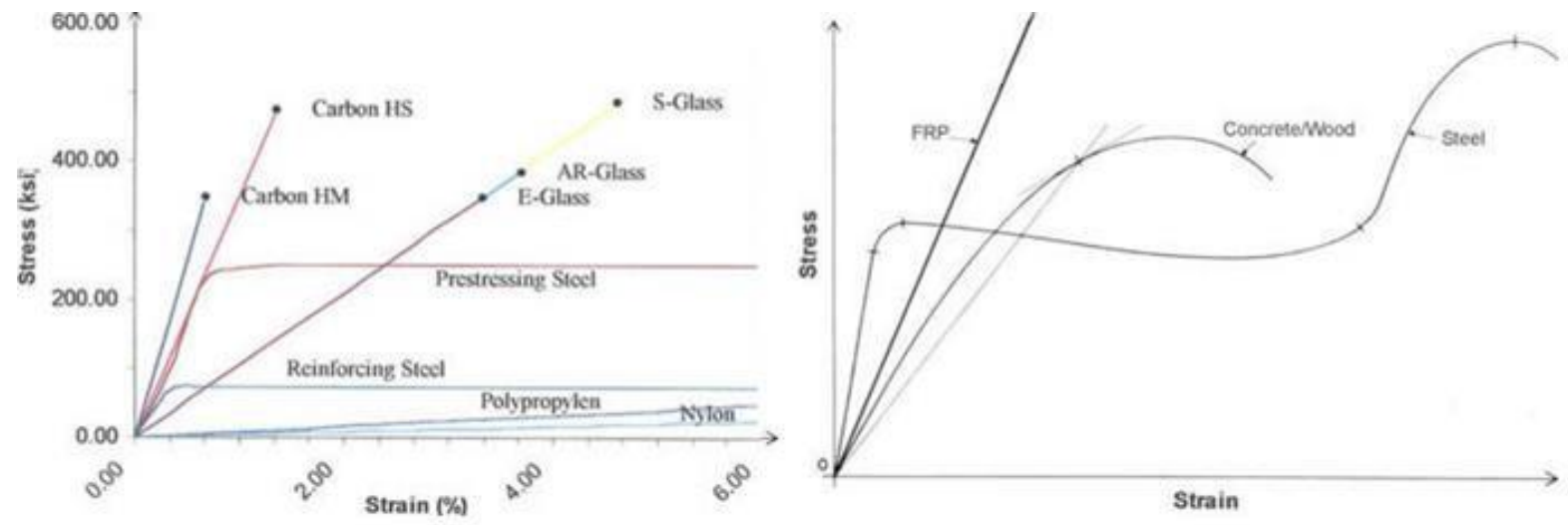

Figure 2.6: Tensile Stress-Strain Behavior of Reinforcing Fibers as Compared With Steel and Various Construction Materials (Gerriste, 1986) (Ambrose, 1993)
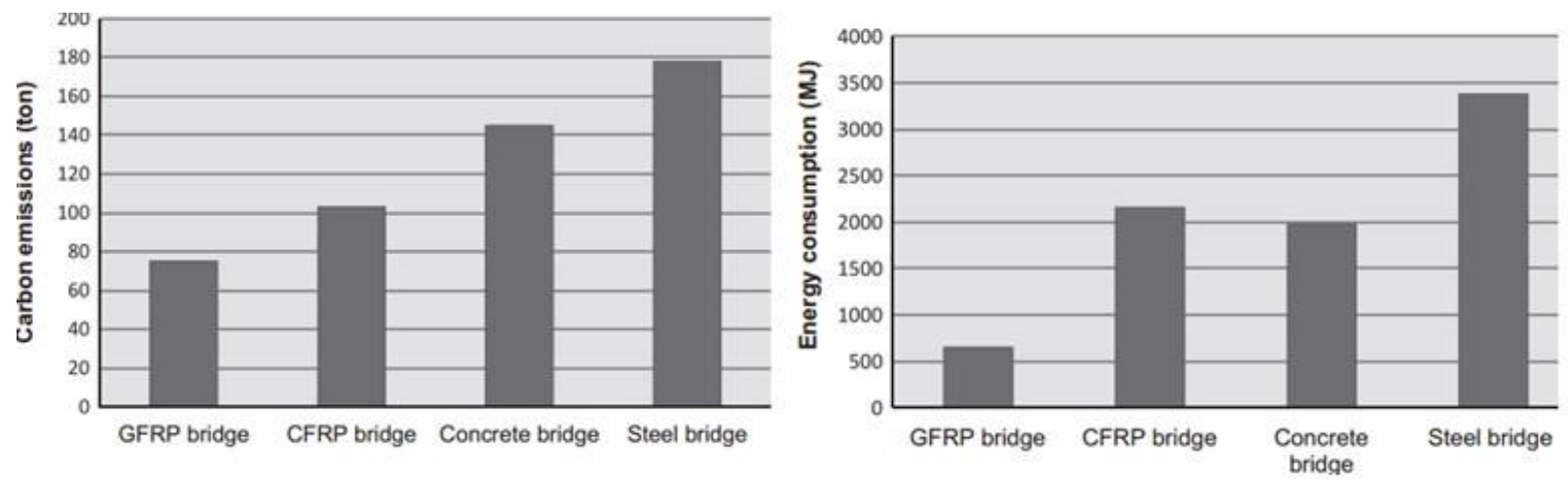

Figure 2.5: Comparison of Carbon emission and Energy consumption for various bridges (Valbona \& Reza, 2014)

The decrease in energy consumption for composite bridges is also attributed to the material savings in the concrete substructure owing to the light weight of FRP materials. 


\subsubsection{Modes of failure}

In unidirectional FRP laminate, failure modes are fiber rupture in tension and buckling in compression, for loading along the fiber axis. For loading away from fiber axis, shear failure is caused for intermediate angles, and transverse tensile and compressive failures are caused for large deviations from the fiber axis. Despite several favorable features the brittle failure of FRP is of utmost concern. FRP mainly fails in shear/flexure, buckling of fibers, and delamination/debonding

Failures in compression members: Use of FRP composites for additional reinforcement and/or confinement in compression members has been a very effective and cost-efficient tool in structural engineering. FRP composite plates or fabrics are bonded or fiber strands are wound in the shear reinforcement direction to enhance shear strength and confinement of steel reinforced concrete members. The wrapped or wound FRP reinforcement confines the concrete to improve the concrete compressive strength as well as the ductility. The lateral confining pressure depends on the thickness and orientation of the FRP reinforcement and the corresponding failure stress as discussed in later chapters.

Failure in tension members: FRP reinforcement for steel becomes effective in the inelastic deformation stage during which steel yields under constant stress while FRPs continue their linearly elastic deformation behavior until failure. Fatigue cracks can develop in tension members or in the tension regions of flexural members and their repair using FRP's is mechanically and economically justified as it improves fatigue resistance as well increases its service life. It also reduces the stress field in the vicinity of the crack, leading to improvement in fatigue life.

Failure in Flexural members: The flexural and shear failure modes are very similar to those encountered in reinforced concrete flexural members. It is observed that concrete member fails by 
crushing whereas the strengthened beams failed by plate rupture or de-bonding (Mohammad, 2008). The de-bonding failure modes, which cannot be characterized by ultimate strength analysis, were of particular concern due to their premature and brittle nature. In case of tubular deck, compression tests on FRP resulted in visible cracks at the corners due to high stress concentrations followed by web buckling (Zhenhua Wu., 2009). This web buckling is likely to initiate flexural crack from at mid-height due to excessive bending or an oblique shear crack in the web (Zhenhua Wu., 2009).Hence proper consideration of all failure modes is necessary otherwise strengthening becomes ineffective as it might turn the ductile member to fail in brittle.

Some experiments conducted by researchers proved FRP de-bonding can be avoided by limiting the FRP force at the last crack equal to tensile strength of concrete $\left(\mathrm{f}_{\mathrm{ct}}\right)$ and a strain limitation of 0.008 is recommended to prevent de-bonding at flexural cracks (Mohammad, 2008). High stiffness was observed in multiple tube deck as the adjacent decks confined each other against lateral buckling (Zhenhua Wu., 2009).

In case of multiple web the interior webs are more susceptible to damage or sometimes be the source for crack initiation/development (Zhenhua Wu., 2009). The interior webs try to buckle outward thereby forcing exterior webs away which reduces the load shared to the exteriors and affects the performance of the interior webs as they have to take additional load which they are not designed to.

Span of the FRP girder played a significant role in influencing the response and mode of failure. It also characterizes short spanned decks tend to local buckling of the flanges whereas the others predominantly failed in tension (Zhenhua Wu., 2009). 


\subsection{Failure modes in timber beams}

Timber failure modes are usually categorized based on the mode they fail in tension, compression and horizontal shear. It is understood from various coupon tests that direct tensile strength is three times as high as compressive strength. So timber beams (green or moist) are probably expected to fail due to crushing in compression zone followed by failure in tension region. On the contrary, dry one's exhibit first visible failure in tension region which makes it clear that timber behaves quite different in axial and bending formats and the stress results from axial tests are not inferable to other tests.

There various other factors like toughness or the brittleness, grain direction, defects (knots, cups, rots, bow, and split etc.) that dictate the disparity in failure criteria. In (Samuel, 1914) six common forms of failure for timber beams without any strengthening reinforcement are mentioned:

1. Simple tension: Tension side of the beam due to stress parallel to grain triggers pulling of timber in opposite direction. Seasoned or dried timber mostly experience this kind of failure.

2. Cross-grained tension: Tensile force acting at some angle to the grain cause this failure. This is most common when beam has spiral, diagonal grain pattern.

3. Splintering tension: A number of failures in tension are induced under the load and are common in tough timbers and surface of fracture is fibrous.

4. Brittle tension: this failure is sudden without prior indication and fails all across the depth of the beam. This kind of fracture is described as brash.

5. Compression failure: Common in green or moisture timber and failure appears at various heights from the neutral axis of the beam. Compressive load parallel to the grain buckles or bends them just as in compression in edgewise testing. This failure initiates in the top 
fibers after it reaches elastic limit and sometimes reaches the neutral axis before complete failure occurs. Hence the failure in the dry beam is different from the moist as drying enhances the stiffness of the fibers to offer high resistance to crushing, whereas it exhibits less effect on the tensile strength.

6. Horizontal shear failure: here both upper and lower portions of the beam slide along each one another for certain length from one or at both ends. It is quite common in air dry timber, green material where the span to depth ratio is very nominal. 


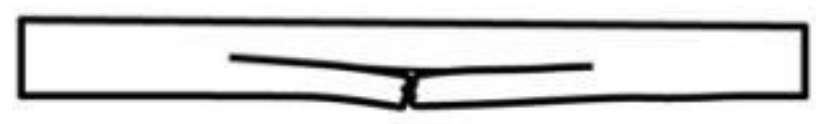

(a) Simple Tension.

(Side View)

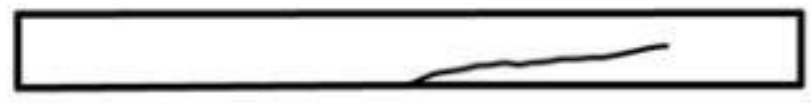

(b) Cross-Grain Tension.*

(Side View)

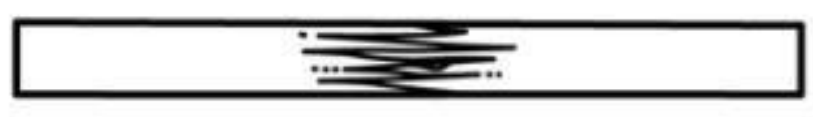

(c) Splintering Tension.

(View of Tension Surface)

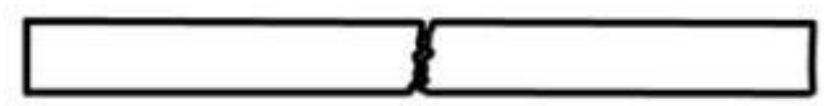

(d) Brash Tension.

(View of Tension Surface)

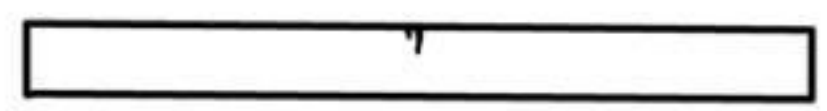

(e) Compression.

(Side View)

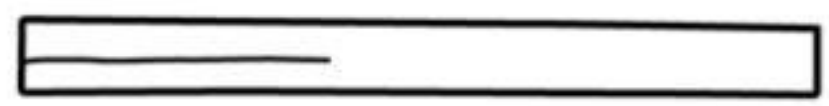

(f) Horizontal Shear.

Figure 2.12: Flexural failure modes in timber beams (Samuel, 1914)

\subsection{Failure modes in Timber-FRP interface:}

Similar to FRP with concrete, failure in timber-FRP interface is caused due to de-bonding or delamination. De-bonding may be due to separation between FRP laminate and adhesive or between timber and the adhesive. Delamination causes separation between adjacent layers within the laminate. In hybrid system such as glue laminated timber beams with FRP strips bonded with 
adhesives are the reason for loss of face to face local adhesion is the main cause of delamination at the interface (Bonacci, 1996). Initiation of delamination may be due to manufacturing defects, bond deterioration or damage due to local impact.

De-bonding and anchorage failures in FRP are most common for concrete beams in flexure but in case of timber ones it is clear from previous research that delamination occurred in very few cases. This proves that timber would be one such material that can be repaired using FRP. However timber-FRP adhesion doesn't pose a problem but the adaptability of resin to adverse environmental conditions (like fully exposed conditions in all weather conditions, long term durability) is of high concern.

Bond between materials is a medium to transfer the load between timber and FRP and enhances the load carrying capacity of the timber beam. It is important that bond strength between timber and FRP has to be greater than individual strengths of timber and FRP, as this ensures the beam to fail after utilizing the ultimate capacity of FRP.

To conclude there hasn't been much research done on bonding performance between FRP and timber but however, FRP-concrete bond behavior can be improved by mainly two categories namely deformation of outer surface and surface treatments. Results from (Pellegrino, Tinazzi, \& Modena, 2008) show that stiffness and bond strength are responsible for controlling the mode of failure but the failure are more or less brittle.

Timber beams strengthened using FRP experience de-bonding failure in laminates or bonding agent may be classified as following: 


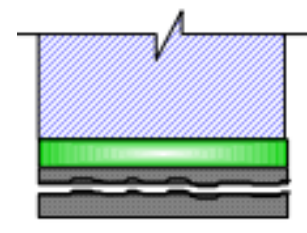

(a)De-bonding in the

FRP

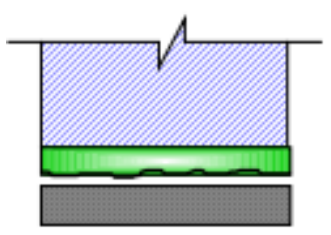

(b) De-bonding FRP and agent

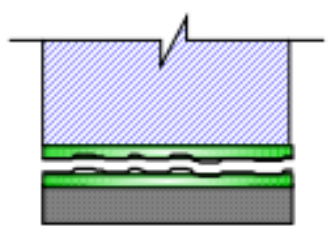

(c) De-bonding in the bonding agent

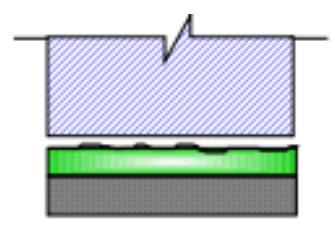

(d) De-bonding between timber and bonding agent

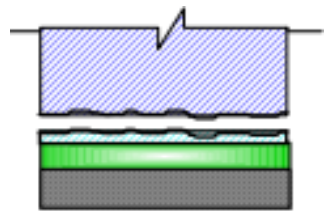

(e) De-bonding in the timber substrata

Figure 2.13: Failure modes of FRP and bonding agent for strengthened beam (Ahmad, 2010)

Peeling off is either one of the failures shown in the Figure 2.13 above but occur at the end of the FRP plate. In fact, peeling off is a common failure mode to most of the RC beams externally bonded using FRP plate. However, this failure is not expected to occur to the timber beams strengthened using FRP with sufficient bonding length (Ahmad, 2010).

\subsection{Timber beams strengthened with FRP in flexure and shear}

Wood is a unique construction material. Although wood had played a significant role in construction industry over decades but the reputation of impermanence and limited application has always been there. A new form of wood construction with external bonded fiber reinforced plastics 
(FRP) on the tension zones of wood using epoxy is an effective strengthening technique not only for new construction but also in rehabilitating already existing structures that stood for decades and over time have shown reduction in performance.

Wood members have been reinforced using many techniques like using steel reinforcement in glulam beams, steel and aluminum plates are used between laminations in horizontal and vertical directions, high strength steel wire embedded in an epoxy matrix has been used to replace tension laminations, glulam has been pre-stressed using stranded cable. None of the techniques reached full commercialization and some are time consuming.

A new method in [6] involves external bonding of thin FRP sheets on tension side of wood structures using epoxy and yields members with enhanced strength, stiffness and ductility linearly with the area ratio (area of FRP to area of timber) independent of the reinforcing material. The failure is governed by wood compressive yield followed by rupture of composite sheet, in turn produces tensile fracture of wood in tension face.

Extremely thin FRP sheets on the tension side offers several advantages, increasing strength, ductility and stiffness characteristics of the members is clearly understood and experimentally verified by tests on beams and beam-columns reinforced with unidirectional carbon/epoxy FRP sheets (Triantafillou., 1992).

In (Thanasis C. Triantafillou., 1992 ) a novel technique is introduced in timber beams by strengthening with pre-stressed FRP externally on the tension zone and verified with tests on carbon/epoxy pre-stressed wood beams. Pre-stressing increases the ultimate bending capacity of the member to a significant level, provided for certain level of FRP area fractions (low) the initial pre-stress is not too high. This technique had dual benefits of strengthening the wood and 
reinforcing it at the same time. Analytical model is also developed for prediction of maximum FRP pretension, so that failure of wood beam doesn't occur upon release of pre-stress.

In (Alann, 2009) it has been shown that it is possible to increase the flexural, shear properties or both together depending on strengthening device and pattern. Tensile failure in timber is brittle so the aim is to achieve a ductile failure in compression followed by tensile fracture so FRP layers are bonded in tension side. Use of FRP to reinforce wood in shear have been investigated although studies have been limited since shear is a rare failure mode for timber beams.

It is understood that modulus of elasticity of composites can be increased by about three times by using reinforcing fibers such as Kevlar or Graphite (Hamid Saadatmanesh., November, 1991).

In (K.U. Schober., 2005) load deflection is seen to be linear elastic up to local failures due to knots and cracks etc. Wood yielding produced a non-linear response terminated by sudden CFRP rupture followed by wood fracture in tension zone resulting in beam collapse. The wood beams reinforced with CFRP lamellas revealed more ductile behavior and arrests crack opening, confines local rupture and bridges local defects in the timber resulting higher load capacity.

Strengthening schemes are investigated in load carrying capacity of timber in shear and flexure. GFRP dowels in the center of the cross-section along the length provides shear strengthening and near surface mounted GFRP bars add flexural strength thereby increasing the ultimate strength and reduces its variability.

Dowel spaced equal to depth of section is more cost effective option with $33 \%$ MOR increase and beams reinforced with both kinds of reinforcement experienced more than $47 \%$ increase in MOR where supposed tensional brittle failure is replaced by compressive failure accompanied by large deflections. Steel dowels had a 25\% increase in MOR but didn't perform well with epoxy as it experienced de-bonding at the interface thereby concluding to use GFRP for any future necessities. 
Horizontal shear cracks are also arrested with dowel shear reinforcement and tension failure are eliminated by flexural reinforcement in the tension zone (D. Svecova., 2004).

Composite sandwich beams in edge wise position failed with $25 \%$ higher bending strength but have $7 \%$ lower bending stiffness than beams in flatwise position. Specimen in edgewise failed with great ductility due to the fiber composite skins, whereas the flatwise position failed in a brittle manner due to de-bonding between skin and core (A.C. Manalo. T. A., 2010).

Load deflection behavior of composite sandwich beam summarized reduction in stiffness of the beam due to tensile cracking in the core part but sustains from immediate failure due to presence of fiber composite skins. The results conclude, bending strength in flat wise position is not influenced by interrupting the number of laminations contrarily, it increases bending strength and prolonged stability in edgewise (A.C. Manalo. T. A., 2010).

Sandwich when tested in edge wise position failed at higher load than in flatwise position and the shear capacity increases with increase in laminations and is experimentally verified when alteration in laminations improved shear strength by over $200 \%$. It is understood that beam in flatwise position is governed by shear strength of the core while in edge wise by shear strength of the skin and is justified when edge wise skin carries $60 \%$ of load but only $20 \%$ on flatwise (A.C. Manalo. T. A., 2013).

In flatwise position with the number of laminations being increased, shear strength of glued sandwiched beams is almost constant or slightly decreasing contrarily, in edge wise position increasing laminations resulted in increase of shear strength.

Flatwise positioned failure is sudden and catastrophic as the core material fails in shear. Edge wise positioning led shear crack in core but the presence of vertical fiber skin impeded the shear crack propagation (A.C. Manalo. T. A., 2013). 
In (Thansis., May 1997) mechanical behavior of wood either reinforced or strengthened with composite materials in the form of laminates or fabrics bonded to the shear critical zones. Shear capacity increases with increase of area ratio or modular ratio and decrease of $h_{\text {frp }} / h$. Decrease of $\mathrm{h}_{\text {frp }} / \mathrm{h}$ never means it should be very low, as shear failure of wood outside unreinforced part will occur prior to reinforced part. In this study it is understood that a little FRP reinforcement can go a long way toward relieving shear stress in timber structures.

\subsection{Confinement effect of FRP on timber poles}

Timber poles, piles, posts have been being used for decades as structural and construction infrastructure elements. Timber unlike its counterparts is more susceptible to damage due to change in temperatures, moisture content, weathering and fungi attacks and are in definite need of repair. Fiber reinforced polymers are considered to be effective in improving strength, ductility, durability and resisting chemical and insect attack.

FRP fabric confinement increases strength, ductility and stiffness, reduces the variability in timber column behavior under axial load and increases toughness in compression. Confinement enhances reliability of FRP timber members and allows for higher resistance factor in design. Full fiber or fabric wrap confinement is more effective than spirals or hoops but results from several studies also suggest that this effectiveness will become less pronounced as the fiber content keeps increasing (Husam Najm., 2007).

A study on the compressive behavior and failure modes of timber columns with longitudinal cracks by using FRP sheets is carried out by (Weiping Zhang., 2012). Replacing the damaged regions, injecting resin into cracks and weaker zones are some techniques that are employed, but the amount of strength recovery that could be achieved is difficult to quantify as per the authors. They have also investigated the effectiveness of metallic confinement and report that there are compatibility 
issues and rusting. FRP wrapping of cracked timber columns in their study increase the loadcarrying capacity by up to $20 \%$.

Load carrying capacity of the timber column decreases with the increase in the length and width of the crack as wider cracks reduce the flexural stiffness EI. Load carrying capacity decreases at a rate of third order of the increase in crack width and a rate of second order with respect to increased length despite the influence of local defects (Weiping Zhang., 2012).

Accelerated aging induces significant deterioration in un-retrofitted timber piles but the effects are relatively minor in the FRP wrapped specimens the peak stress and ductility increase even after extreme degradation (Kim 2016).

When subjected to axial loading, timber piles without FRP wrap exhibit splitting of grains followed by crushing and buckling of fibers. In case of FRP retrofitted piles, localized FRP rupture .... timber crushing/buckling. Accelerated aging causes excessive splitting and reduction of strength in wood. Aging led to a reduction of $31 \%$ of peak stress and $17 \%$ in elastic modulus of the unwrapped specimen but with FRP peak stress went up by 10\%, and stiffness was unaffected (Kun Ho Eugene Kim., 2016).

In a study by (SONG Xiaobin1., 2010) on timber cylinders, crushing wrinkles of wood at the midheight of cylinder were noted when loaded till $80 \%$ of maximum load. Wrinkles become more apparent with the load increase. Some failures had composite sheets splitting with $70 \%$ to $80 \%$ of maximum load and show compressive wrinkles at the mid height finally laterally deflecting. Other set of samples experienced failure at the ends of the cylinder, predominantly crushing deformation. 


\subsection{ADHESIVES}

An adhesive is material used for holding two surfaces together. An adhesive is a polymer mixture or polymerizable material in a liquid or semiliquid state that adheres substrates together (Petrie, 2000).

The various components of an adhesive formulation include the following: primary resins, solvents, fillers, plasticizers, reinforcements, thickeners and thixotropic agents, film formers, antioxidants, antifungal agents, emulsifiers, and wetting agents (Petrie, 2000). All resins are adhesives but all adhesives need not necessarily be resins.

Adhesives are classified by many methods such as dispensing method, application, and primary resins.

Table 1: Classification of adhesives (Dostal, 1990)

\begin{tabular}{|l|l|}
\hline Classification & Primary resins \\
\hline Anaerobic adhesive & Polyester, urethane, epoxy, silicone, acrylate \\
\hline Elastic adhesive & Silicone, urethane, polysulfide \\
\hline Conductive adhesive & $\begin{array}{l}\text { Epoxy, acrylate, polyimide, silicone, EVA, } \\
\text { phenol }\end{array}$ \\
\hline Flame-retardant adhesive & $\begin{array}{l}\text { Polybenzimidazole, polyquinoxazoline, } \\
\text { epoxy }\end{array}$ \\
\hline Damping adhesive & Silicone, polyvinylalcho \\
\hline
\end{tabular}

\subsubsection{RESIN}

Resins of adhesives and sealants are the principal component that provide wettability, adhesion strength, thermal property, chemical resistance, and environmental resistance. The word "resin" means a hydrocarbon secretion of many plants, particularly coniferous trees.

Resins are mainly classified as thermoplastics and thermosets: 
- Thermoplastics

- Thermosets

2.10.1.1Thermoplastic Resins: A thermoplastic resin is a polymer that can turn to a melting liquid when it is heated and returns to solid when it is cooled down (Dostal, 1990).

Table 2: Thermoplastic resins with advantages and disadvantages (Dostal, 1990)

\begin{tabular}{|l|l|l|}
\hline & Advantages & \multicolumn{1}{c|}{ Limitations } \\
\hline Acrylate & $\begin{array}{l}\text { Good UV resistance } \\
\text { Good solvent resistance } \\
\text { Good shear strength }\end{array}$ & $\begin{array}{l}\text { Poor creep resistance } \\
\text { Fair initial adhesion } \\
\text { Moderate cost }\end{array}$ \\
\hline Polyvinyl alcohol & $\begin{array}{l}\text { Water soluble resin } \\
\text { Good wettability to porous } \\
\text { substrate such as wood } \\
\text { Quick set }\end{array}$ & $\begin{array}{l}\text { Poor water resistance } \\
\text { Poor heat resistance } \\
\text { Poor creep resistance }\end{array}$ \\
\hline Ethylene vinyl acetate & $\begin{array}{l}\text { Application to hot-melt } \\
\text { Good wetting and adhesion } \\
\text { Good flexibility }\end{array}$ & $\begin{array}{l}\text { Poor heat resistance } \\
\text { Poor creep resistance }\end{array}$ \\
\hline
\end{tabular}

2.10.1.2 Thermosetting Resins: Thermosetting materials are generally stronger than thermoplastic materials due to 3-D network of bonds, and are also better suited to high-strength and hightemperature applications (Dostal, 1990).

Table 3: Thermosetting resins with advantages and disadvantages (Dostal, 1990)

\begin{tabular}{|l|l|l|}
\hline Epoxy & Advantages & \multicolumn{1}{|c|}{ Limitations } \\
\hline Polyurethanes & $\begin{array}{l}\text { High strength } \\
\text { Good solvent resistance } \\
\text { Good gap-filling capabilities } \\
\text { Relatively low cost }\end{array}$ & $\begin{array}{l}\text { Exothermic reaction } \\
\text { Exact proportions needed } \\
\text { for optimum properties } \\
\text { Short pot life }\end{array}$ \\
\hline Phenolic & $\begin{array}{l}\text { Various cure times } \\
\text { Tough } \\
\text { Excellent flexibility even at and cured } \\
\text { low temperature }\end{array}$ & $\begin{array}{l}\text { Both uncured and } \\
\text { are moisture sensitive } \\
\text { Poor heat resistance } \\
\text { Short pot life }\end{array}$ \\
\hline $\begin{array}{l}\text { Good heat resistance } \\
\text { Good dimensional stability } \\
\text { Inexpensive }\end{array}$ & $\begin{array}{l}\text { Brittle } \\
\text { Possibility of pollution } \\
\text { due to formaldehyde as } \\
\text { curing agent }\end{array}$ \\
\hline
\end{tabular}


Adhesion with wood is obtained with most adhesives when the moisture contents of about 6 to 17 percent, and with some glues well beyond this range (up to 25 pct. has been reported for resorcinol adhesives). Moisture is sometimes responsible for blisters (un-bonded areas caused due to steam at the joint when moisture content is too high) (Selbo., 1975).

The mechanical properties of fiber-reinforced polymer composites are highly dependent on good load transfer from the fibers to the matrix material, which in turn is significantly impacted by the interface between the fiber and matrix. Most fiber-reinforced polymer composites fail because of inadequate bonding at the interface between reinforcement and matrix resin (Williamson, 2002). Epoxy have great versatility, high mechanical properties, corrosion resistant. They cure slowly and are quite brittle after they are fully cured. Compared to polyester, epoxy resins shrink less and have high strength/stiffness at moderate temperature. Vinyl ester offers a transition in mechanical properties and offers less shrinkage and more chemically resistant. Phenolic resins are predominantly used adhesive system for wood composite industry. They have excellent physical and mechanical durability. Phenolic Resorcinol formaldehyde resins are popular as a resin matrix for FRP and as a binder in many other applications (Williamson, 2002).

Findings showed that with specific adhesives, cost-effective thin bond lines have the capacity to resist severe hygrothermal stresses imposed at the FRP-wood interface. Adhesive bonding is identified as the most efficient method of stress transferal between two materials as it avoids the stress concentrations that are associated with mechanical fasteners. Epoxy adhesives using a bond line thickness of approximately $0.5 \mathrm{~mm}$ can form strong durable bonds between wood and FRP. Significant improvements in the mean shear strength and mean adherend failure percentages of the moisture cycled specimens were also noted for particular adhesive/FRP combinations (Gary M. Raftery., 2009). 
Shear strength of Phenol resorcinol formaldehyde (PRF) bonded specimen is higher than polyvinyl acetate (PVA). A 25\% reduction in shear strength of PVAc bonded specimen under Phenol formaldehyde (PF) modified wood. Lowest penetration into porous network of interconnected cells, at $25 \% \mathrm{PF}$ concentration is noticed as it is dominated by flow through the vessels and limited to few cells near the bond line (Stergios Adamopoulos., 2012). It is also clearly understood that PVA adhesive must never be used with wood modified with PF as it offers zero shear bond strength and very little wood failure.

Shear strength is an interfacial stress between the samples is a reference parameter to compare the bond strength of various adhesives. So Polyvinyl acetate (PVA), Polyurethane (PU) and Urea formaldehyde (UF) adhesives shear strengths are determined in timber members. Errors during cutting effect the stability of the shear strength and some errors lead the applied load to move away from the bond line direction, which has negative effect on the results. It is evident from various tests that PU and PVAs adhesives exhibit higher strengths (Mohammad Derikvand., 2016).

In the evaluation of shear strength, the kind of adhesive, thickness of the joint has no significance effect on the shear capacity and fracture behavior. Annual ring orientation to the adhesion joint has a significant effect on shear strengths and is verified when radial orientation has $19.7 \%$ higher shear strength than tangential one. In case of shear tests on composite sections, high shear strengths can be achieved when shear stresses are transferred by an adhesion of timber material with the UHPC (Ultra high performance concrete) (Martin Schafers., 2010).

2.11 Summary: In this chapter, use of timber and FRP for construction and rehabilitation of bridge structures have been reviewed with respect to material properties, failure modes, research findings and few field installations. 


\section{Chapter 3. EXPERIMENTAL DETAILS}

\subsection{Introduction}

This chapter describes the procedures employed in testing the FRP bridge deck specimen, and coupons (tension and bending) derived from the deck specimen. The chapter also includes details on specimen preparation, test set up, experimental procedure and test results.

\subsection{FRP Bridge Deck Test}

FRP bridge deck specimen is tested in 3-point bending to evaluate its bending behavior, failure loads and, modes. Strains and deflections are recorded at different locations during the testing.

\subsubsection{Test Sample}

The FRP Bridge deck specimen consists of several webs and foam core sandwiched top and bottom flanges. The flanges consist of glass fiber fabrics and XXXX, whereas foam cure is made ofpolyurethane which serves as a filler material. The bridge deck with a dimension of 48.0 " $\mathrm{x}$ $10.25 " \times 3.5 "$ designated as Sample 1 and the dimensions are provided in table 3.1.

Table 3.4: Detailed dimensions of the FRP deck sample

\begin{tabular}{|c|c|c|c|c|c|c|}
\hline Sample No. & $\begin{array}{c}\text { Measurements } \\
(\mathrm{L} \mathrm{x} \mathrm{W} \mathrm{x} \mathrm{H)}\end{array}$ & $\begin{array}{c}\text { Span } \\
\text { (in.) }\end{array}$ & $\begin{array}{c}\text { Flange } \\
\text { Width } \\
\text { (in.) }\end{array}$ & $\begin{array}{c}\text { Flange } \\
\text { Thickness } \\
\text { (in.) }\end{array}$ & $\begin{array}{c}\text { Web } \\
\text { Height } \\
\text { (in.) }\end{array}$ & $\begin{array}{c}\text { Web } \\
\text { Thickness } \\
\text { (in.) }\end{array}$ \\
\hline 1. & $\begin{array}{c}48.0 " \times 10.25 ” \times \\
3.5 ”\end{array}$ & $40.0 ”$ & 10.25 & 0.313 & 2.874 & 0.098 \\
\hline
\end{tabular}



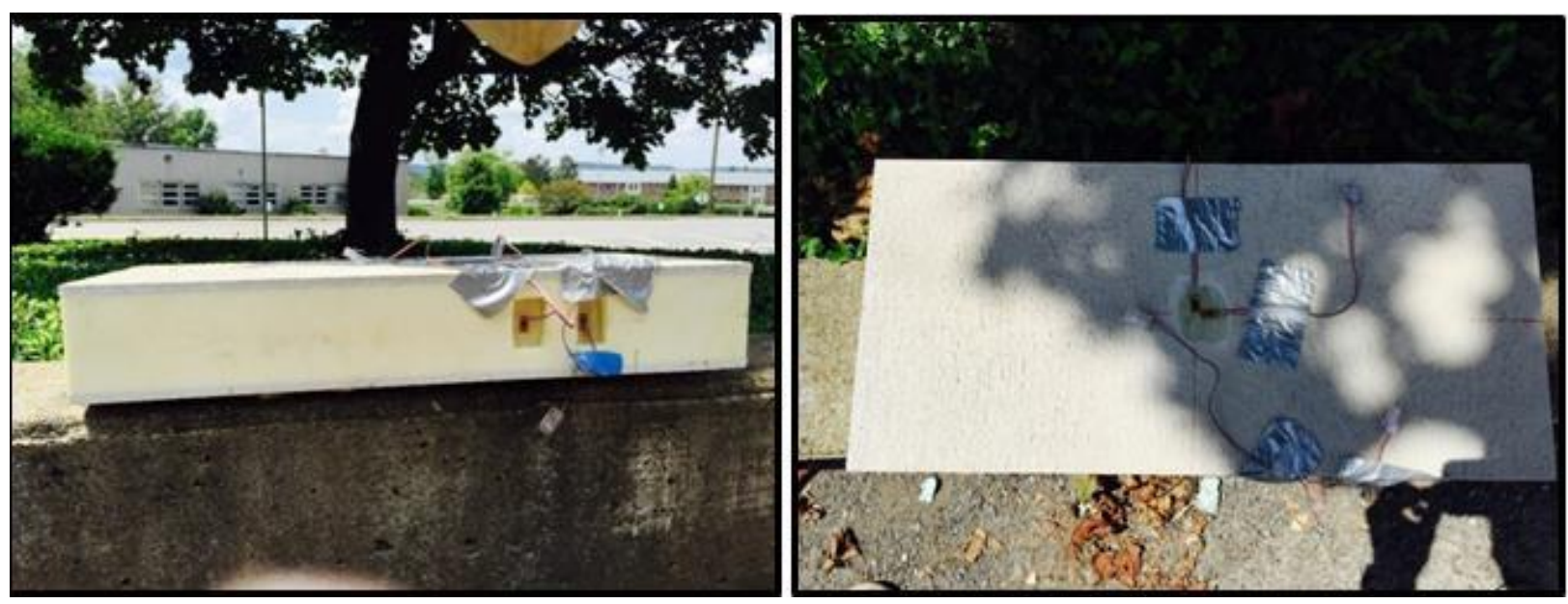

Figure 3.1: Strain gages attached FRP deck specimen1, for shear measurement (Left) and bending stress at center of the span (Right)

\subsubsection{Specimen Preparation}

Prior to the test, the FRP deck specimen is attached with strain gages on the flange and web surfaces which are prepared by careful grinding of the wearing surface course. Strain gages are attached at the center on both tension and compression flanges both in longitudinal and transverse directions and also on the web at a distance of " $\mathrm{d} / 2$ " from the face of the support.

\subsubsection{Test Set-up and Test Procedure}

The FRP deck specimen is tested under three-point bending load as shown in Figure 3.2. The load is applied manually and the capacity of the loading jack is 60 Tons. Strain-Smart data acquisition system is used to record the load, strains, and deflections until failure. 


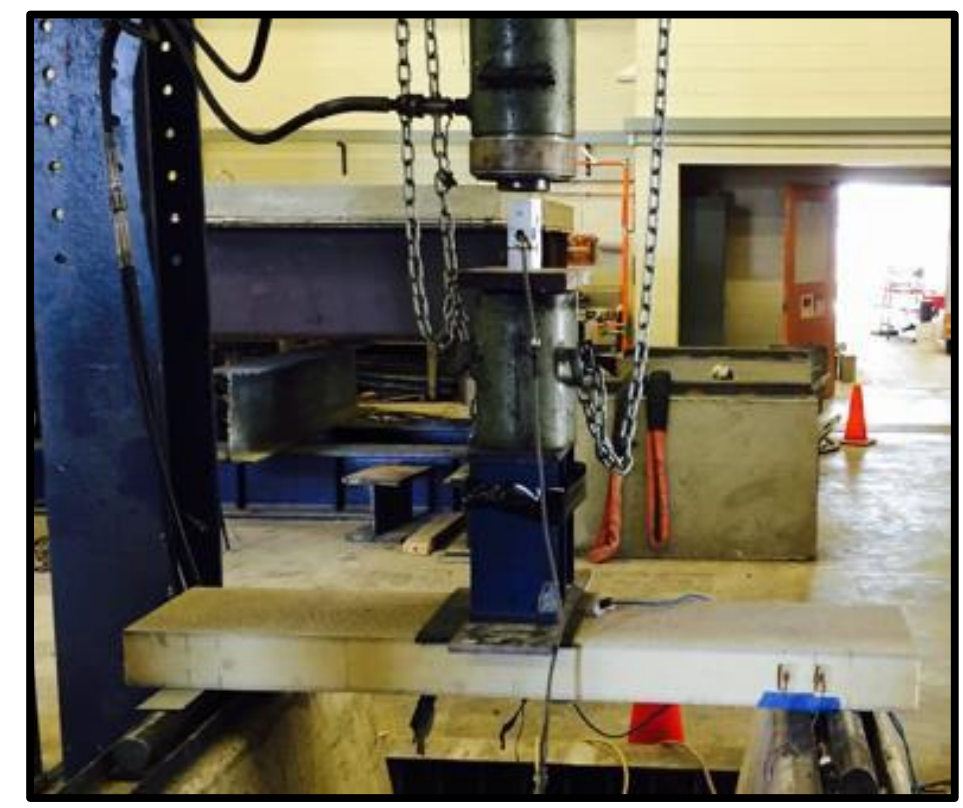

Figure 3.2: Sandwich Bridge deck FRP specimen tested in bending

\subsection{Coupon Tension Test}

Tension tests as per ASTM D 3039 are carried out on samples cut from the deck web and flange locations in order to assess the strength, stiffness, tensile modulus, and strain energies. . The first set of samples are cut from the flanges in longitudinal direction. The second set of samples are cut from the flanges in lateral direction. The third set of samples, are cut form the webs along the length of the deck and the fourth set corresponds to the height of the web. All the coupon specimens are tested in tension to evaluate tensile strength, stiffness, and elongation.

\subsubsection{Tension Test Specimen}

The longitudinal FRP coupon specimens are cut to a length of 14.0" with a cross-sectional dimension being 1.0 "x 0.313 ". Three specimens each of 14.0 " length are tested in tension as per ASTM D 3039. The samples derived from lateral direction are 10.0" in length and 1.0" x 0.313 " in cross-section. Similar to the longitudinal samples, three lateral samples are tested in tension as per ASTM D 3039. 

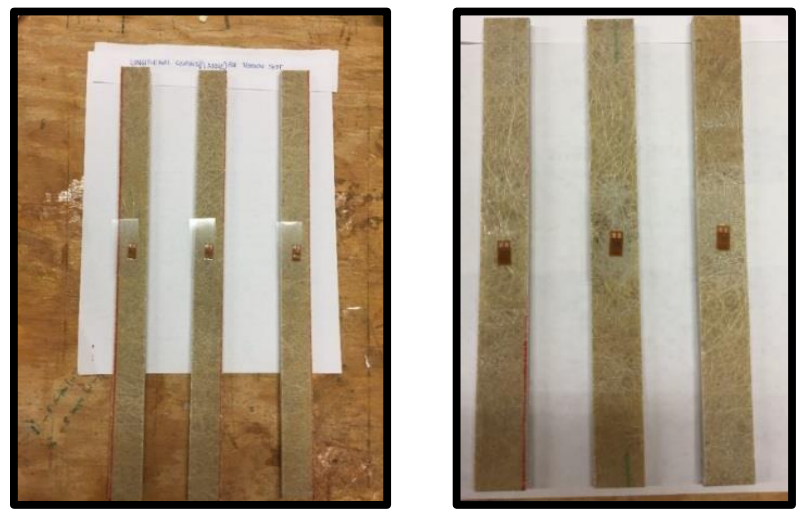

Figure 3.3: Longitudinal and lateral coupons with strain gages attached

\subsubsection{Specimen Preparation}

The specimens that are cut to required lengths of 14.0" and 10.0" in longitudinal and lateral directions are prepared for mounting the strain gages by removing the resin rich top layer with a coarse and fine sand papers. End tabs (grips) are usually provided, but according to 8.2.1.2 of ASTM D 3039 tabs are not always required provided the thickness of the sample is higher. The main motive of providing the tabs is to eliminate the eliminate the failure in grip zones and also create load uniformity in the specimen to prevent premature failure. ASTM D 3039 strongly insists on the coupon length to be substantially longer than the minimum requirement to avoid bending stresses caused by minor grip eccentricities. Cross-sectional dimensions and other specifications are shown in the Table 3.2 below. 
Table 3.5: Details of coupons tested in tension (ASTM D 3039/D 3039M)

\begin{tabular}{|c|c|c|c|c|c|}
\hline Sample & $\begin{array}{l}\text { No. of } \\
\text { samples }\end{array}$ & $\begin{array}{l}\text { Length of } \\
\text { the sample } \\
\text { (in.) }\end{array}$ & $\begin{array}{l}\text { Cross-sectional } \\
\text { dimensions (in. } \\
\mathrm{x} \text { in.) }\end{array}$ & $\begin{array}{l}\text { Gage } \\
\text { length } \\
\text { (in.) }\end{array}$ & $\begin{array}{l}\text { Grip/Tab } \\
\text { length } \\
\text { (in.) }\end{array}$ \\
\hline $\begin{array}{l}\text { Longitudinal } \\
\text { Flange }\end{array}$ & 3 & $14.0 ”$ & $1.0 " x$ x $0.313 "$ & $10.2 ”$ & $1.90 ”$ \\
\hline Lateral Flange & 3 & $10.0 "$ & $1.0 " x$ 0.313" & $10.2 "$ & $1.90 "$ \\
\hline Longitudinal Web & 3 & $14.0^{\prime \prime}$ & $1.0 " \times 0.098 "$ & $10.2 ”$ & $1.90 "$ \\
\hline Vertical Web & 3 & 2.656" & $0.375 "$ x $0.098 "$ & - & $1.90 ”$ \\
\hline
\end{tabular}
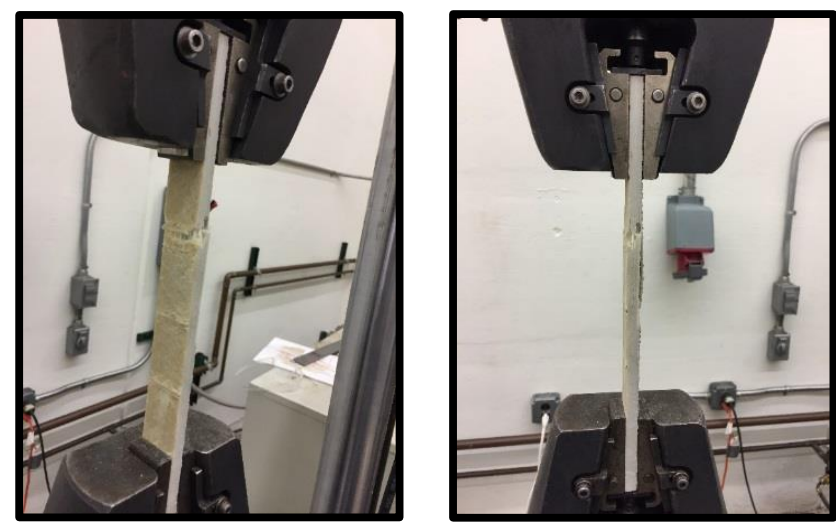

Figure 3.3: Tension tests on longitudinal and lateral coupons of the FRP deck material

\subsubsection{Test Set-up and Test Procedure}

The coupon specimens are tested using INSTRON (MTS 8500 Plus) testing machine as shown in Figure 3.3. Data acquisition system is used to record all the load and strain data. The specimen is tested until failure to evaluate the ultimate failure stress of the coupon.

\subsection{Bending tests}

Bending tests are carried out on a set of coupons and also on the cross-sectional sample of the bridge deck. Bending strength, stiffness and flexural modulus of the material can be determined from the coupon tests. All bending tests are conducted in compliance with ASTM D790. 


\subsubsection{Bending Test Specimen}

The bending test specimens are prepared as per ASTM 790D by cutting the FRP bridge deck specimen. Three bending coupon specimens each are obtained in the longitudinal and lateral direction (Table 3.3). A cross-sectional sample of the bridge deck measuring 1.0" is also cut from the deck and tested in bending (Table 3.4). All the specimens are tested in bending as per ASTM D790 standards.
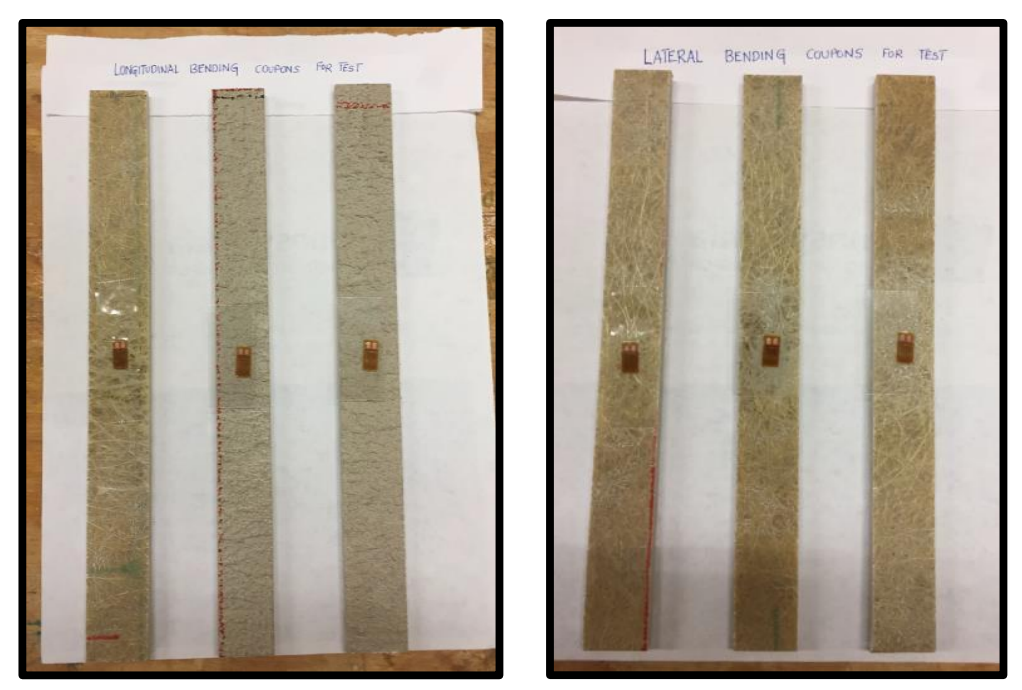

Figure 3.4: Longitudinal and lateral coupons to be tested for bending (ASTM D790)

\subsubsection{Coupon and Deck0 Bending Specimen Preparation.}

Specimen are cut from the available sample in both longitudinal and lateral direction each measuring 10.0 " in length. The surface of test specimen is prepared for mounting the strain gages on the tension side of the bending samples in order to determine required properties (bending strength, stiffness). 
Table 3.3: Dimensions of longitudinal and lateral samples tested in bending (ASTM D790)

\begin{tabular}{|c|c|c|c|c|c|}
\hline Sample & $\begin{array}{c}\text { No. of } \\
\text { samples }\end{array}$ & $\begin{array}{c}\text { Length of the } \\
\text { sample (in.) }\end{array}$ & $\begin{array}{c}\text { Cross- } \\
\text { sectional } \\
\text { dimensions } \\
\text { (in x in.) }\end{array}$ & $\begin{array}{c}\text { Gage } \\
\text { Length } \\
\text { (in.) }\end{array}$ & $\begin{array}{c}\text { Grip length on } \\
\text { either sides } \\
\text { (in.) }\end{array}$ \\
\hline $\begin{array}{c}\text { Longitudina } \\
1\end{array}$ & 3 & $10.0 "$ & $1.0 " \times 0.313 "$ & $6.2 ”$ & $1.90 "$ \\
\hline Lateral & 3 & $10.0 "$ & $1.0 " \times 0.313 "$ & $6.2 ”$ & $1.90 "$ \\
\hline
\end{tabular}

Table 6.4: Dimensions of C/S sample model of the deck

\begin{tabular}{|c|c|c|c|c|c|c|}
\hline Sample & $\begin{array}{c}\text { Measurements } \\
(\mathrm{L} \times \mathrm{W} \times \mathrm{H})\end{array}$ & $\begin{array}{c}\text { Span } \\
\text { (in.) }\end{array}$ & $\begin{array}{c}\text { Flang } \\
\mathrm{e} \\
\text { Widt } \\
\mathrm{h}\end{array}$ & $\begin{array}{c}\text { Flange } \\
\text { Thickne } \\
\mathrm{ss} \\
\text { (in.) }\end{array}$ & $\begin{array}{c}\text { Web } \\
\text { Heigh } \\
\mathrm{t} \\
\text { (in) }\end{array}$ & $\begin{array}{c}\text { Web } \\
\text { Thicknes } \\
\mathrm{s} \\
\text { (in.) }\end{array}$ \\
\hline $\begin{array}{c}\text { C/S of } \\
\text { Deck }\end{array}$ & $\begin{array}{c}10.25 ” \times 1.0 " \mathrm{x} \\
3.5\end{array}$ & $\begin{array}{c}7.87 \\
5\end{array}$ & 10.25 & 0.313 & 2.874 & 0.098 \\
\hline
\end{tabular}

\subsubsection{Coupon Bending Test Set-up and Test Procedure}

The coupons spans are to be perfectly centered between the supports and loading is adjusted exactly over the center of the coupon in an INSTRON (MTS 8500 Plus) testing machine as per ASTM D790. Three-point bending tests are carried out on the bending coupons and cross-sectional sample of the deck.

All the bending tests are position based i.e. rate of movement of loading head is $0.34 \mathrm{in} . / \mathrm{min}$. Data acquisition system is used to record all the data (load applied and strain induced) until specimen failure. 

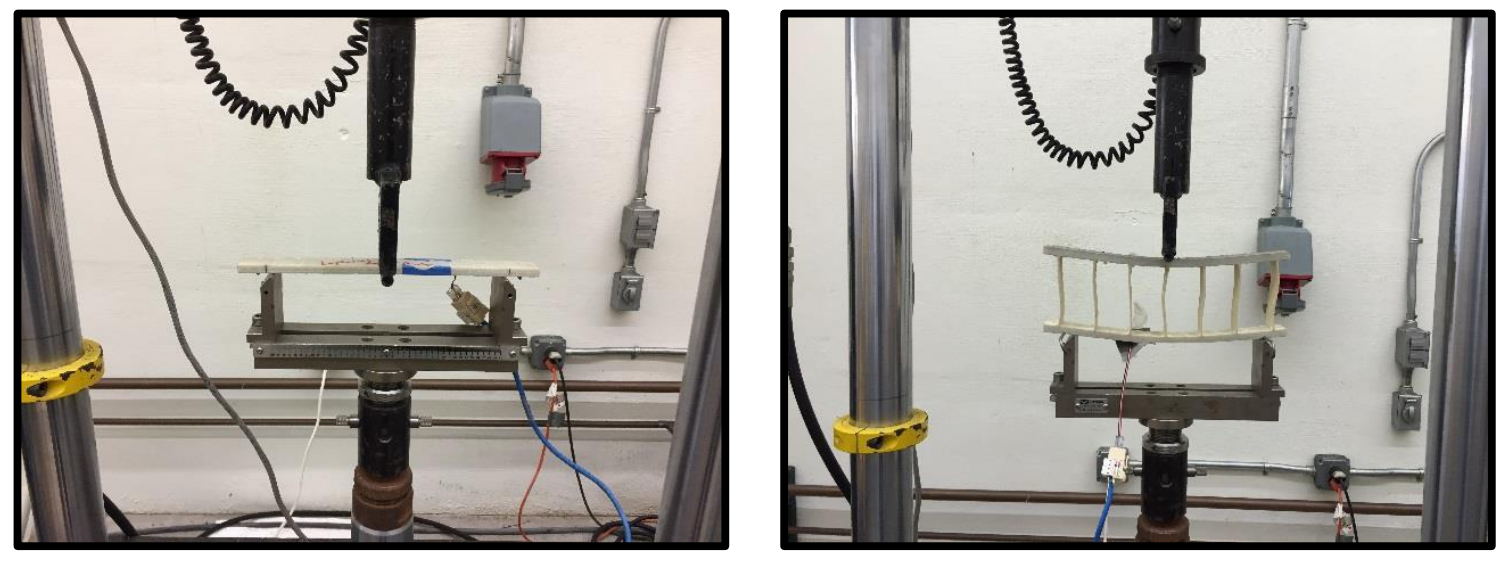

Figure 3.5: Bending Test set up (a) Coupon (left) (b) deck cross-section (right)

\subsection{Timber Beam Test}

Four types of timber beams are tested with different spans and loads with and without carbon FRP on the tension side. Thirteen (13) timber tests are carried out on the specimens under four-point bending. Maximum deflections, strains and failure loads are noted for each beam specimen.

\subsubsection{Beam Test Specimen}

All the timber specimens are Southern Yellow pine species except for one which is Douglas fir. Both treated and untreated specimens were tested. Some of these specimens were tested by gluing them together to increase the width of the specimen by gluing and bolting. Some of these specimen is tested until $40 \%$ of their failure load. and then the span is increased prior to application of loads to failure. Details of the test specimens are given in Table 3.5.

Table 3.4: Treated and un-treated samples with various dimensions and species

\begin{tabular}{|c|c|c|c|c|c|}
\hline S.No & $\begin{array}{c}\text { C/S } \\
\text { Dimensions }\end{array}$ & $\begin{array}{c}\text { Length } \\
\text { (in.) }\end{array}$ & $\begin{array}{c}\text { Number of } \\
\text { Specimens }\end{array}$ & Treatment & Species \\
\hline 1 & 6.0 " 6.0 " & 12.0 & 2 & Treated & Southern yellow pine \\
\hline 2 & 2.0 " $\times 10.0 "$ & 16.0 & 5 & Treated & Southern yellow pine \\
\hline 3 & 2.0 " $\times 12.0 "$ & 16.0 & 2 & Untreated & Southern yellow pine \\
\hline 4 & 4.0 " $\times 4.0$ " & 8.0 & 2 & Untreated & Douglas Fir \\
\hline
\end{tabular}




\subsubsection{Type 1: 2.0” x 10.0”}

2.0" x 10.0" specimens are $12.0 \mathrm{ft}$. length. Two out of five specimens mentioned in Table 3.6 are tested until load reaches a value $40 \%$ of its failure load for $7.0 \mathrm{ft}$. span and loaded to failure for $11.0 \mathrm{ft}$. spans.

These Specimens are also tested by gluing them together to achieve larger widths prior to bonding FRP fabrics (Table 3.6).

Table 3.6: Tests on 2.0" $\times 10.0^{\prime \prime}$ Specimens with and without FRP for different spans.

\begin{tabular}{|c|c|c|c|c|c|}
\hline Species & $\begin{array}{c}\text { Cut } \\
\text { Length }\end{array}$ & Specimen & Test span & Load Value & L/d \\
\hline & ft. & & & $\%$ of Failure & \\
\hline SYP & 12.0 & No FRP & $7.0 \mathrm{ft.}$ & $40 \%$ & 9.08 \\
\hline & & No FRP & $11.0 \mathrm{ft}$. & $40 \%$ & 14.3 \\
\hline SYP & 12.0 & No FRP & $7.0 \mathrm{ft}$. & $40 \%$ & 9.08 \\
\hline & & No FRP & $11.0 \mathrm{ft.}$ & $40 \%$ & 14.3 \\
\hline & & No FRP & $11.0 \mathrm{ft.}$ & $40 \%$ & 14.3 \\
\hline & & FRP & $7.0 \mathrm{ft}$. & $40 \%$ & 9.08 \\
\hline & & FRP & $11.0 \mathrm{ft}$. & $100 \%$ & 14.3 \\
\hline & & No FRP & $11.0 \mathrm{ft}$. & $40 \%$ & 14.3 \\
\hline & & FRP & $7.0 \mathrm{ft.}$ & $40 \%$ & 9.08 \\
\hline & & FRP & $11.0 \mathrm{ft}$. & $100 \%$ & 14.3 \\
\hline
\end{tabular}

\subsubsection{Type 2: 2.0" x 12.0"}

These 2.0 " x 12.0 " specimens are $16.0 \mathrm{ft}$. long and two of these are glued together and tested for various spans (Table 3.7). The beam specimen is tested at 7 and $9 \mathrm{ft}$. spans with and without FRP for a maximum of $40 \%$ its failure load and finally tested to failure at $14.0 \mathrm{ft}$. span with FRP on the tension side. 
Table 3.7: 2.0" X 12.0" Specimens with and without FRP for Different Test Spans

\begin{tabular}{|c|c|c|c|c|c|}
\hline $\begin{array}{c}\text { Specie } \\
\text { S }\end{array}$ & $\begin{array}{c}\text { Cut } \\
\text { Length } \\
\text { ft. }\end{array}$ & Specimen & $\begin{array}{c}\text { Test } \\
\text { span }\end{array}$ & $\begin{array}{c}\text { Load Value } \\
\text { \% of } \\
\text { Failure }\end{array}$ & L/d \\
\hline SYP & 15.0 & No FRP & $7.0 \mathrm{ft}$. & $40 \%$ & 7.47 \\
\hline & & No FRP & $9 \mathrm{ft}$. & $40 \%$ & 9.6 \\
\hline & & No FRP & $11.0 \mathrm{ft}$. & $40 \%$ & 11.74 \\
\hline & & FRP & $7.0 \mathrm{ft}$. & $40 \%$ & 7.47 \\
\hline & & FRP & $9 \mathrm{ft}$. & $40 \%$ & 9.6 \\
\hline & & FRP & $11.0 \mathrm{ft}$. & $40 \%$ & 11.74 \\
\hline
\end{tabular}

3.5.1.3

Type 3:

\section{0" x 6.0"}

These solid beams are $12.0 \mathrm{ft}$. long and tested in bending under four-point loading, these specimens are tested without FRP in the tension zone for two spans, i.e., $7.0 \mathrm{ft}$. (40\% of failure load) and 11.0 ft. (100\% of failure load). The other specimen is tested with similar spans and loading conditions but with a strip of FRP attached on the tension side of the beam before testing (Table 3.8).

Table 3.9: 6.0" $\times$ 6.0" beam test configuration with and without FRP at various loading and test span conditions

\begin{tabular}{|c|c|c|c|c|c|c|}
\hline $\begin{array}{c}\text { In } \\
\text { No. }\end{array}$ & Species & $\begin{array}{c}\text { Cut } \\
\text { Length } \\
(\mathbf{f t} .)\end{array}$ & Specimen & $\begin{array}{c}\text { Test } \\
\text { span }\end{array}$ & $\begin{array}{c}\text { Load } \\
\text { Value } \\
(\%) \\
\text { Failure) }\end{array}$ & L/d \\
\hline 1 & SYP & 12.0 & No FRP & $7.0 \mathrm{ft}$. & $40 \%$ & 15.3 \\
\hline & & & No FRP & $11.0 \mathrm{ft}$. & $100 \%$ & 24 \\
\hline 1 & SYP & 12.0 & FRP & $7 \mathrm{ft}$. & $40 \%$ & 15.3 \\
\hline & & & FRP & $11.0 \mathrm{ft}$. & $100 \%$ & 24 \\
\hline
\end{tabular}




\subsubsection{Type 4: 4.0" $x$ 4.0"}

These beams are tested for spans of $5.0 \mathrm{ft}$. and $7.0 \mathrm{ft}$. with loads $40 \%$ of failure and $100 \%$ failure loads respectively without FRP and other sample is tested with similar conditions but with an FRP strip on the tension side as shown in described in Table 3.10.

Table 3.10: 4.0" x 4.0" beam test configuration with and without FRP at various loading and test span conditions

\begin{tabular}{|c|c|c|c|c|c|c|}
\hline In No. & Species & $\begin{array}{c}\text { Cut } \\
\text { Length }\end{array}$ & Specimen & $\begin{array}{c}\text { Test } \\
\text { span }\end{array}$ & Load Value & L/d \\
\hline & & ft. & & & \% of Failure & \\
\hline 1 & DF & 8.0 & No FRP & $5.0 \mathrm{ft}$. & $40 \%$ & 17.1 \\
\hline & & & No FRP & $7.0 \mathrm{ft}$. & $100 \%$ & 24 \\
\hline 1 & DF & 8.0 & FRP & $5.0 \mathrm{ft}$. & $40 \%$ & 17.1 \\
\hline & & & FRP & $7.0 \mathrm{ft}$. & $100 \%$ & 24 \\
\hline
\end{tabular}

\subsubsection{Specimen Preparation}

The surface of the beams has to be planed so as to avoid bends due to warping in the boards before starting any procedure. The samples are glued together using Phenolic and the surface is prepared to attach strain gages on both tension, compression zones and also at shear dominant locations. Beam specimens are also bonded with FRP in the tension zone, and cured five days for the FRP to attain ultimate performance characters.

\section{Adhesive for Joining Boards:}

Cascophen is a liquid, phenol-resorcinol timber laminating resin. The setting of the material is obtained through reaction with a definite proportion of a dry powdered hardener, Cascoset. Ratio

of $100: 17$ by weight of Cascophen and Cascoset are mixed thoroughly for about five minutes in a fume hood before application.

\section{Application on the surface:}


A mixed glue line of $391 \mathrm{~g} / \mathrm{m}^{2}$ is evenly spread over the surface using rollers and the boards are joined together by applying a pressure of $800 \mathrm{psi}$ for four hours under the wood board presser. The time of pressure application depends on inner glue line temperature mentioned in the manufactures manual.

Table 3.11: Various clamp time for different glue line temperatures

\begin{tabular}{|c|c|}
\hline $\begin{array}{c}\text { Inner Glue Line } \\
\text { Temperature }\end{array}$ & Minimum Clamp Time \\
\hline $21-21$ & 9 hours \\
\hline $27-30$ & 4 hours \\
\hline $32-35$ & 1.5 hours \\
\hline
\end{tabular}
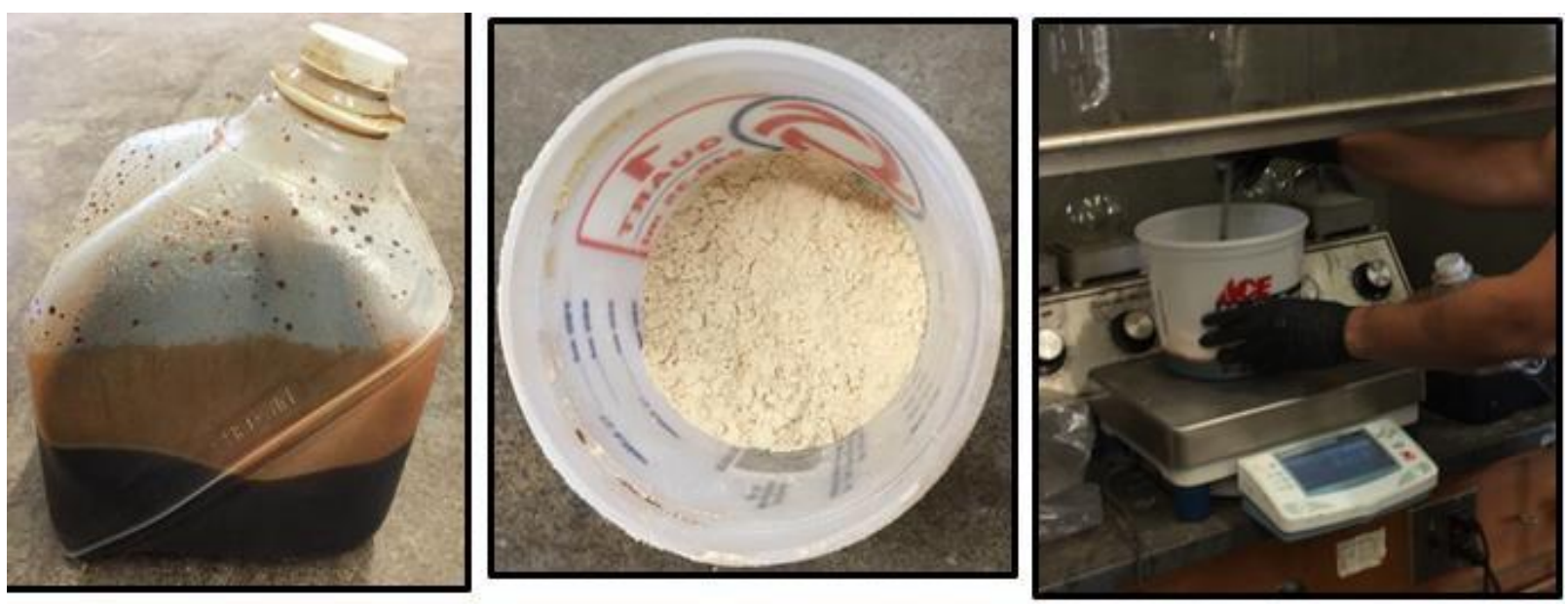

Figure 3.6: Shows the Cascophen and Cascoset and thorough mixing in fume hood 

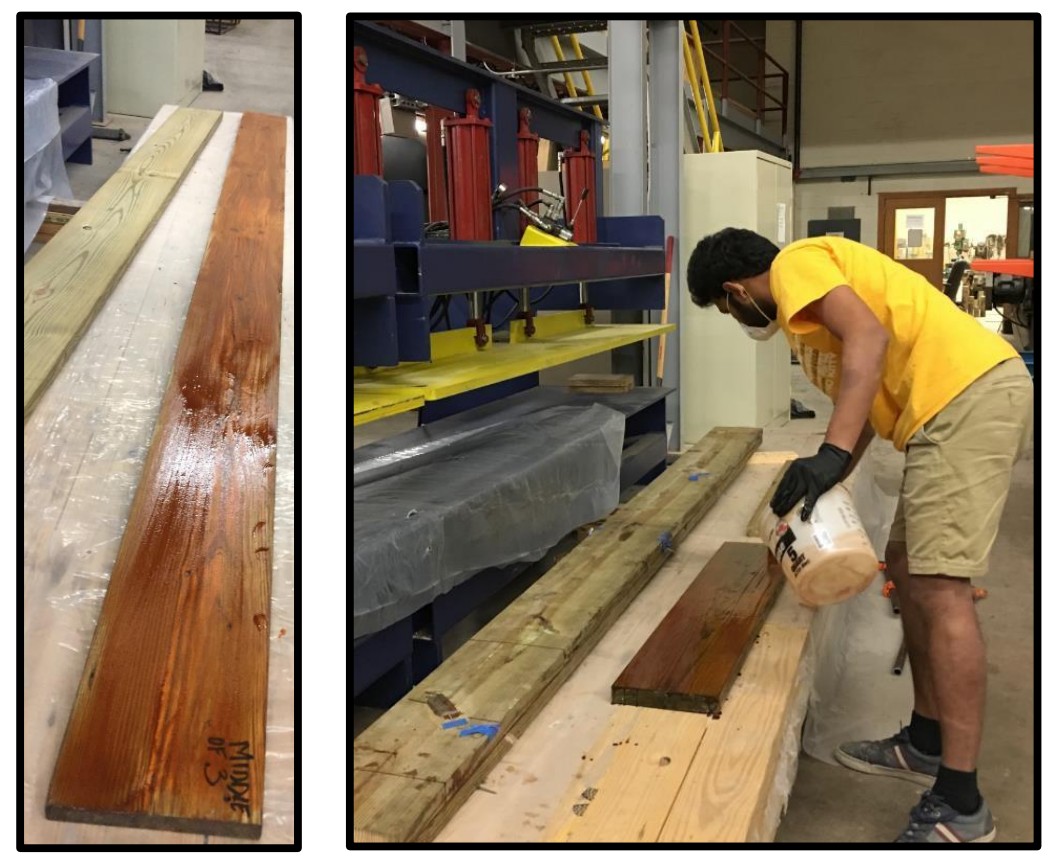

Figure 3.7: Gluing timber members together using Phenolic resin

\section{Bonding of CFRP on tension side:}

Carbon FRP used in this analysis is a pre-impregnated one, which means it needs no resin to be applied manually but instead already induced during manufacturing itself. A primer mixed in the

ratio of 100: 54.4 by weight is applied over the surface of beams before bonding the FRP. Precautionary measures are taken during bonding of FRP to ensure that no bubbles, undulations are generated between the surfaces.

The primer mentioned above is Sikadur-340, chemically called aliphatic urethane constitutes of Part A and B are shown in the Figure 3.7 below. The pre-impregnated FRP used on the tension side is also shown in the Figure 3.8. 

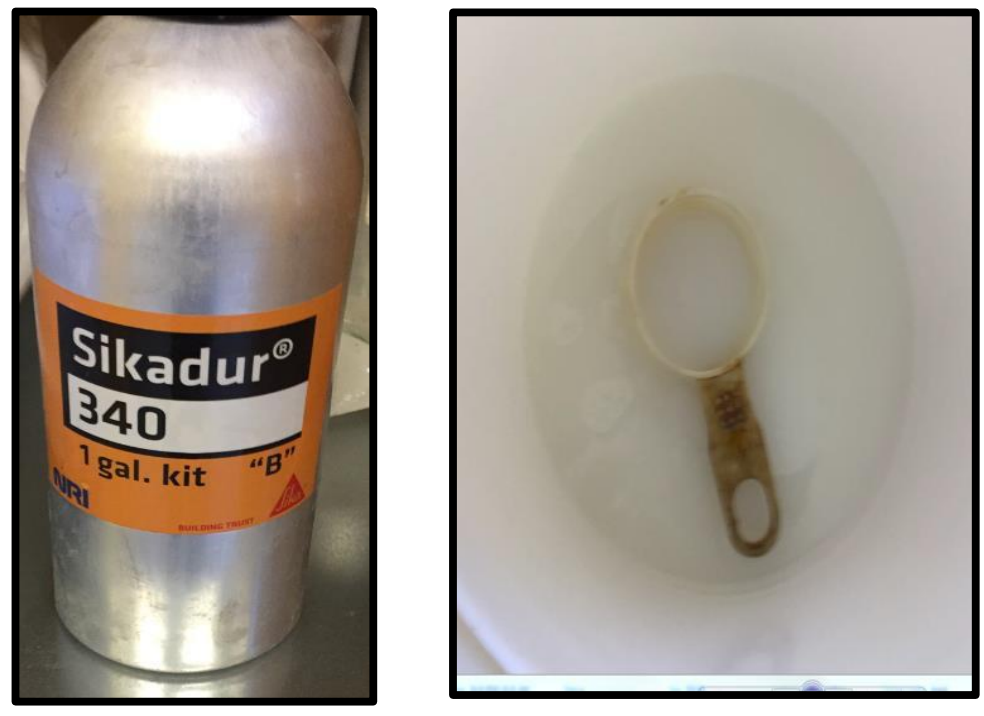

Figure 3.8: Sikadur-340 aliphatic urethane, Part A (left) and B (right)
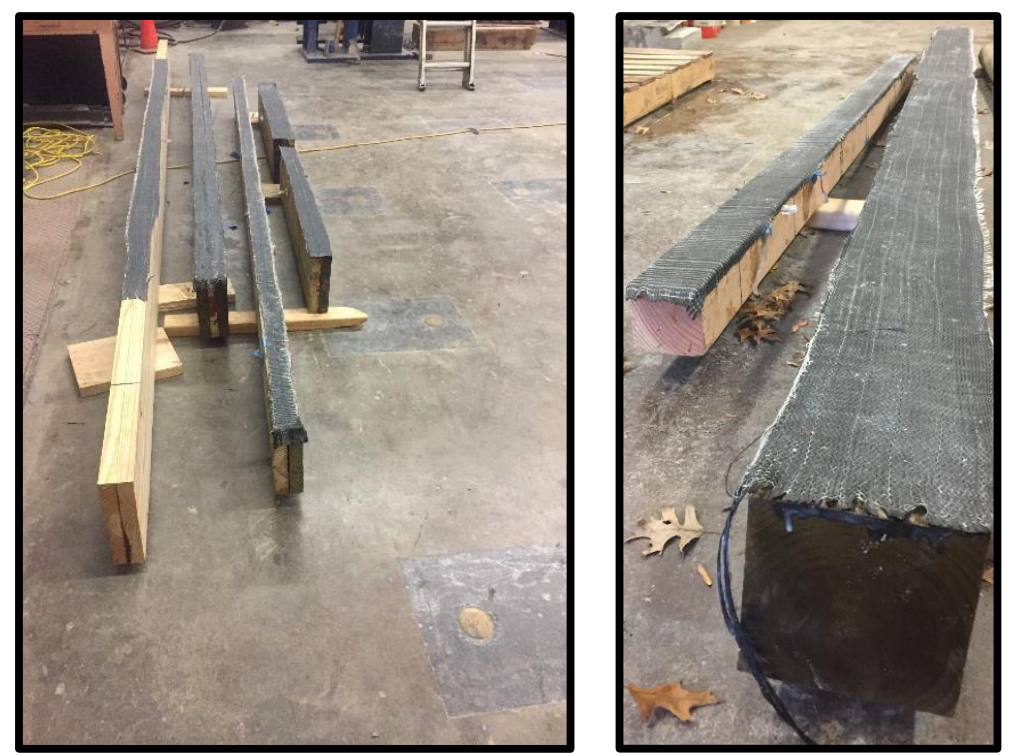

Figure 3.9: Figure showing adhering of FRP on tension side of wood beams

\subsubsection{Test Set-up and Test procedure}

Before the test strain gages, LVDT, Load cell must be checked for any improper functioning and the data acquisition has to be connected to obtain the results. 
The beams are tested in four-point bending as shown in Figure 3.9. The load is applied manually and the capacity of the loading jack is 60 Tons. Strain-Smart data acquisition is used to read the applied load and corresponding strains and deflections developed. As mentioned earlier loading jack is manually operated hence, the strains can't be recorded at constant load intervals. There are several configurations of loading on timber beams where some of them are loaded till $40 \%$ of ultimate load by varying the spans, with and without FRP and others tested for failure. Beam with depth-width ratio of three or greater are subjected to lateral instability during loading thus requires lateral support when tested in bending according to ASTM D198 as shown in Figure. These supports are provided at least at points located about half-way between the reaction and load point. These supports shall allow vertical movement without altering deflection and no frictional restraint. All the required data is obtained from data acquisition for further understanding and analyzing the phenomenon occurring at various scenarios.

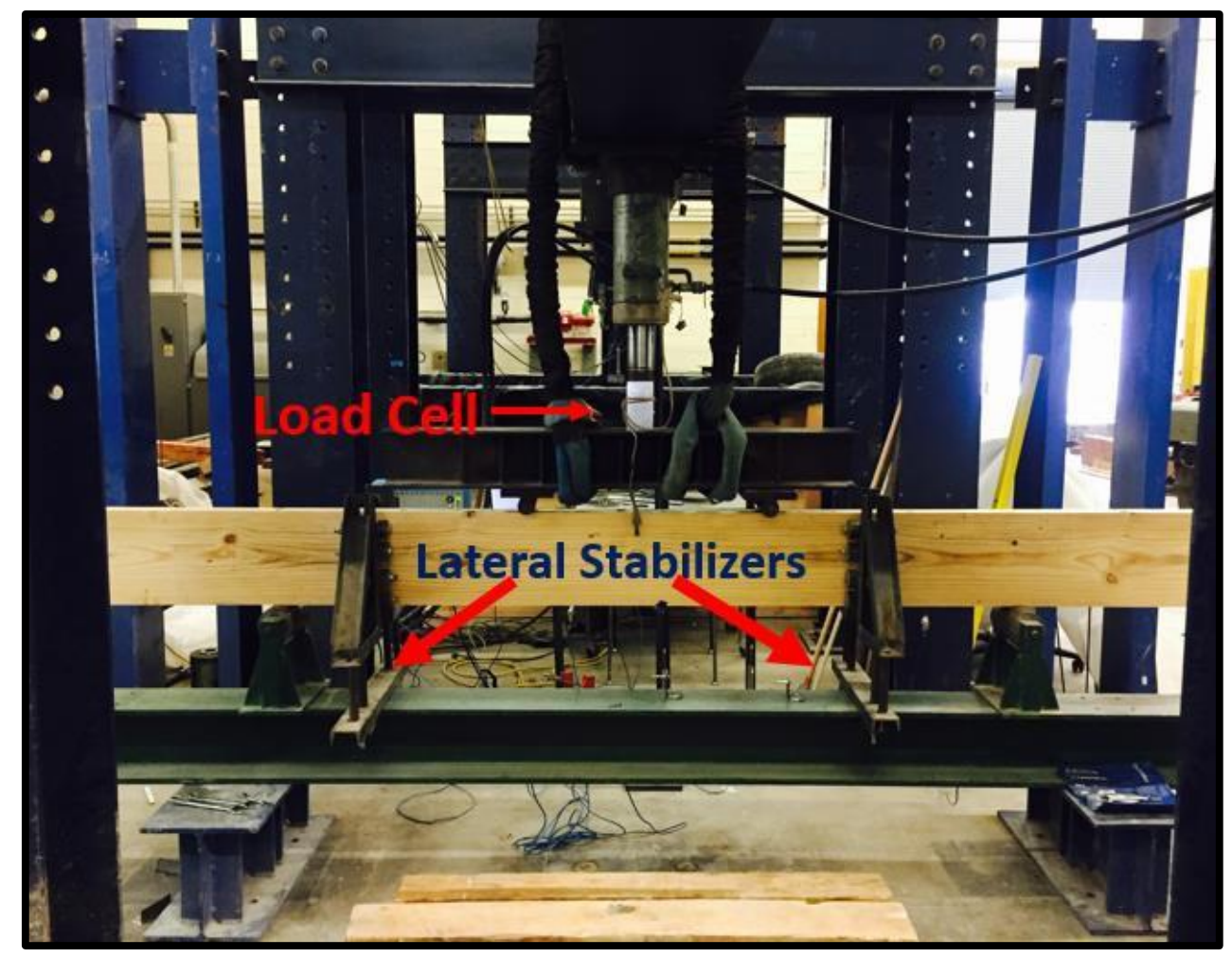




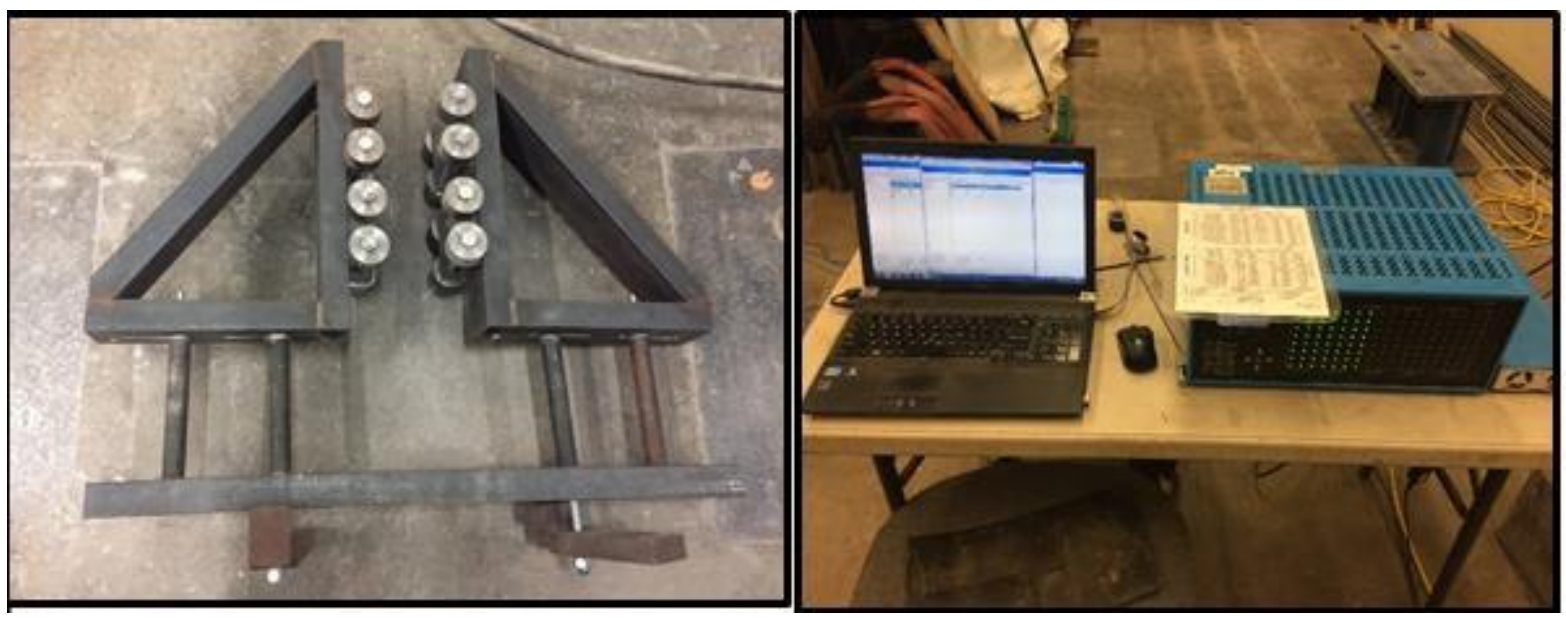

Figure 3.11: Lateral Stabilizers (left) according to ASTM D-198 and Data Acquisition (Right) used during the test

\subsection{Timber Round Poles Test}

Long poles eight feet in length of different diameters are brought and cut to required length. Timber poles each of twelve inch in length and varying diameters of four and six inch are tested in compression. Three samples of each type are tested under INSTRON testing machine. These test samples can be classified as short columns as their slenderness ratio $(\mathrm{L} / \mathrm{r})$ is less than 17.0.

\subsubsection{Test Sample}

The cylindrical samples each eight-inch-long with and without FRP on the circumferential area are tested in compression to examine the confinement effect and also determine the variations in strength. Carbon fiber polymer of one, two and three layers is used for wrapping timber cylinders of 4.0 inch diameter and one and three layers are used on six inch diameter cylinders, as mentioned in the Table 3.11. Glass aqua wrap is also used in one, two and three layers for 4.0 inch timber cylinders.

Table 3.12: Configuration and dimensions of wrapped and unwrapped cylinders 


\begin{tabular}{|c|c|c|}
\hline $\begin{array}{c}\text { Length } \\
\text { (in.) }\end{array}$ & $\begin{array}{c}\text { Diameter } \\
\text { (in.) }\end{array}$ & $\begin{array}{c}\text { Type of } \\
\text { Confinement/ No. } \\
\text { of layers }\end{array}$ \\
\hline 12.0 & 6.0 & No \\
\hline 12.0 & 6.0 & 1 \\
\hline 12.0 & 6.0 & 3 \\
\hline 8.0 & 4.0 & No \\
\hline 8.0 & 4.0 & 1 \\
\hline 8.0 & 4.0 & 2 \\
\hline 8.0 & 4.0 & 3 \\
\hline
\end{tabular}

There are set of other samples with both diameters (4.0 in. and 6.0 in.) drilled with various diameter holes all the way through the length. These core drilled samples are tested without wrap and with one, two and three-layer wrap in compression. The diameter of drilled holes is mentioned in the Tables 3.12 and 3.13 below and shown in Figure 3.11.

Table 3.13: Dimension and drilled core detailing of 6.0 inch and 4.0-inch diameter cylinders

\begin{tabular}{|c|c|c|c|c|c|c|}
\hline $\begin{array}{c}\text { Length of } \\
\text { the } \\
\text { sample } \\
\text { (in.) }\end{array}$ & $\begin{array}{c}\text { Diameter } \\
\text { of the } \\
\text { sample } \\
\text { (in.) }\end{array}$ & $\begin{array}{c}\text { Diameter } \\
\text { of the } \\
\text { core } \\
\text { (in.) }\end{array}$ & $\begin{array}{c}\text { Material } \\
\text { removed } \\
(\%)\end{array}$ & $\begin{array}{c}\text { Diameter } \\
\text { of the } \\
\text { core } \\
\text { (in.) }\end{array}$ & $\begin{array}{c}\text { Material } \\
\text { removed } \\
(\%)\end{array}$ & $\begin{array}{c}\text { Number } \\
\text { of wraps }\end{array}$ \\
\hline 12.0 & 6.0 & 3.625 & 36.5 & 3.0 & 25 & $\mathrm{No} / 1 / 13$ \\
\hline 8.0 & 4.0 & 3.0 & 56.25 & 2.0 & 25 & $\mathrm{No} / 1 / 2 / 2$ \\
\hline
\end{tabular}

Table 3.14: Description of 4.0 inch diameter cylinders with CFRP wrap

\begin{tabular}{|c|c|c|c|c|}
\hline Designation & \multicolumn{3}{|c|}{ Description } & No of \\
\hline Carbon FRP & $\begin{array}{l}\text { Diameter } \\
\text { (in.) }\end{array}$ & Core & $\begin{array}{l}\text { No. of FRP } \\
\text { Layers }\end{array}$ & \\
\hline $4-S-0$ & \multirow{4}{*}{4.0} & \multirow{4}{*}{ Solid } & 0 & 3 \\
\hline $4-S-C 1$ & & & 1 & 3 \\
\hline $4-\mathrm{S}-\mathrm{C} 2$ & & & 2 & 3 \\
\hline $4-S-C 3$ & & & 3 & 3 \\
\hline $4-\mathrm{H} 2-0$ & 4.0 & 2 inch hole & 0 & 3 \\
\hline
\end{tabular}




\begin{tabular}{|c|c|c|c|c|}
\hline $4-\mathrm{H} 3-0$ & 4.0 & 3 inch hole & 0 & 3 \\
\hline $4-\mathrm{H} 2 \mathrm{~F}-0$ & \multirow{4}{*}{4.0} & \multirow{4}{*}{$\begin{array}{l}2.0 \mathrm{inch} \\
\text { filled }\end{array}$} & 0 & 3 \\
\hline $4-\mathrm{H} 2 \mathrm{~F}-\mathrm{C} 1$ & & & 1 & 3 \\
\hline $4-\mathrm{H} 2 \mathrm{~F}-\mathrm{C} 2$ & & & 2 & 3 \\
\hline $\begin{array}{c}4-\mathrm{H} 2 \mathrm{~F}- \\
\mathrm{C} 3\end{array}$ & & & 3 & 3 \\
\hline $4-\mathrm{H} 3 \mathrm{~F}-0$ & \multirow{4}{*}{4.0} & \multirow{4}{*}{$\begin{array}{c}3.0 \text { inch } \\
\text { filled }\end{array}$} & 0 & 3 \\
\hline $\begin{array}{c}4-\mathrm{H} 3 \mathrm{~F}- \\
\mathrm{C} 1\end{array}$ & & & 1 & 3 \\
\hline $4-\mathrm{H} 3 \mathrm{~F}-\mathrm{C} 2$ & & & 2 & 3 \\
\hline $\begin{array}{c}4-\mathrm{H} 3 \mathrm{~F}- \\
\mathrm{C} 3\end{array}$ & & & 3 & 3 \\
\hline
\end{tabular}

Table 3.15: Description of 4.0-inch diameter cylinders with GFRP wrap

\begin{tabular}{|c|c|c|c|c|}
\hline Designation & \multicolumn{3}{|c|}{ Description } & No of \\
\hline Glass FRP & $\begin{array}{l}\text { Diameter } \\
\text { (in.) }\end{array}$ & Core & $\begin{array}{l}\text { No. of FRP } \\
\text { Layers }\end{array}$ & \\
\hline $4-\mathrm{S}-\mathrm{G} 2$ & \multirow[b]{2}{*}{4.0} & \multirow{2}{*}{ Solid } & 2 & 3 \\
\hline $4-\mathrm{S}-\mathrm{G} 3$ & & & 3 & 3 \\
\hline $4-\mathrm{H} 2-\mathrm{G} 1$ & \multirow{3}{*}{4.0} & \multirow{3}{*}{ 2-inch hole } & 1 & 3 \\
\hline $4-\mathrm{H} 2-\mathrm{G} 2$ & & & 2 & 3 \\
\hline $4-\mathrm{H} 2-\mathrm{G} 3$ & & & 3 & 3 \\
\hline $\begin{array}{c}4-\mathrm{H} 2 \mathrm{~F}- \\
\mathrm{C} 1\end{array}$ & \multirow[t]{3}{*}{4.0} & \multirow{3}{*}{$\begin{array}{l}2.0 \text { inch } \\
\text { filled }\end{array}$} & 1 & 3 \\
\hline $\begin{array}{c}4-\mathrm{H} 2 \mathrm{~F}- \\
\mathrm{C} 2\end{array}$ & & & 2 & 3 \\
\hline $4-\frac{\mathrm{H} 2 \mathrm{~F}}{\mathrm{C} 3}-$ & & & 3 & 3 \\
\hline
\end{tabular}



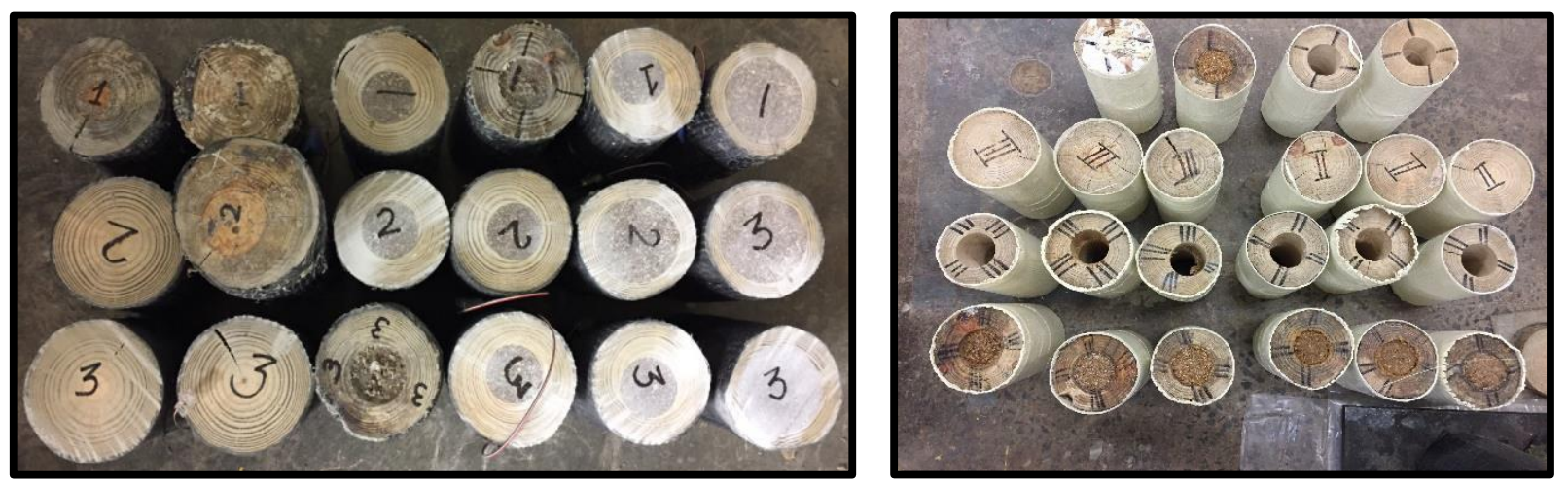

Figure 3.11: Carbon (left) and Glass (right) cylindrical samples ready for testing

\subsubsection{Specimen Preparation}

Cylindrical samples are cut to required length so making sure that both the top and bottom surface are flat so that they can be loaded uniform without any eccentricity. The circumferential surface of the cylinders must be cleaned in order to avoid any undulations or projections from the plane to make wrapping/ bonding easy. Core hole of required diameter is drilled in cylinders as shown in Figure 3.12. The wood flakes obtained during drilling are stored, to be mixed with the resin and filled back.

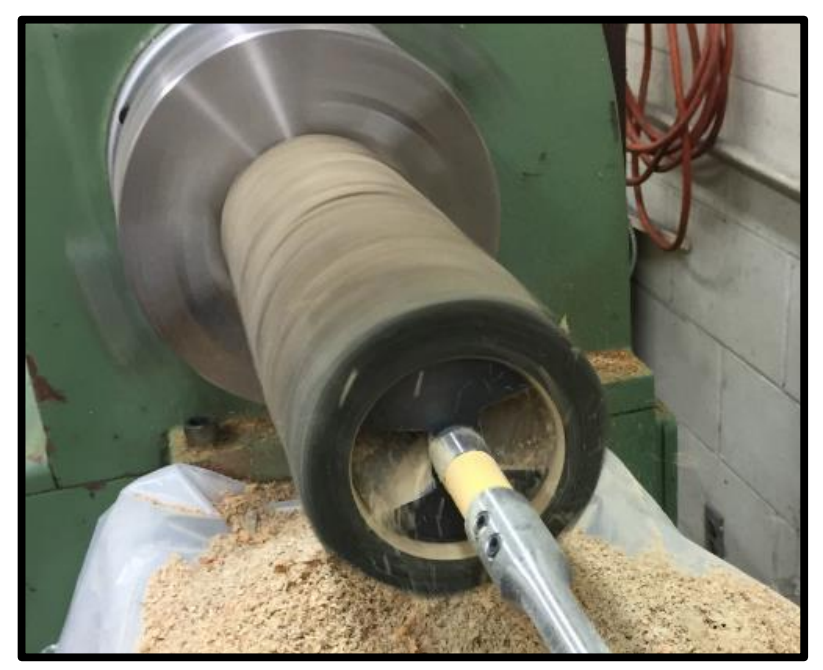

Figure 3.13: Core drilling in a 4.0"cylinder 


\section{Filler Material:}

Core in the cylinders is replenished with a filler material which is a combination of Vinyl ester resin and wood flakes in the ratio 1: 1 by volume. Adhesive is a combination of Hetron-D (highly cross-linked v Methyl Ethyl ketone peroxide (MEKP), Cobalt Naphthenate etc. in the ratio of

100: $0.75: 0.25$ by weight as shown in Figure 3.13 . The resin is mixed thoroughly with wood flakes to obtain a semi solid mixture to be filled in the core drilled cylinders. The bottom of the cylinders is packed with expanding foam so as to arrest any possible leak of resin from the filler material as shown in the Figure 3.14. It is observed that within an hour, an exothermic reaction starts by releasing heat and simultaneously hardens the filler material. Core filled cylinder samples are undisturbed and allowed to set for $24-48$ hours.
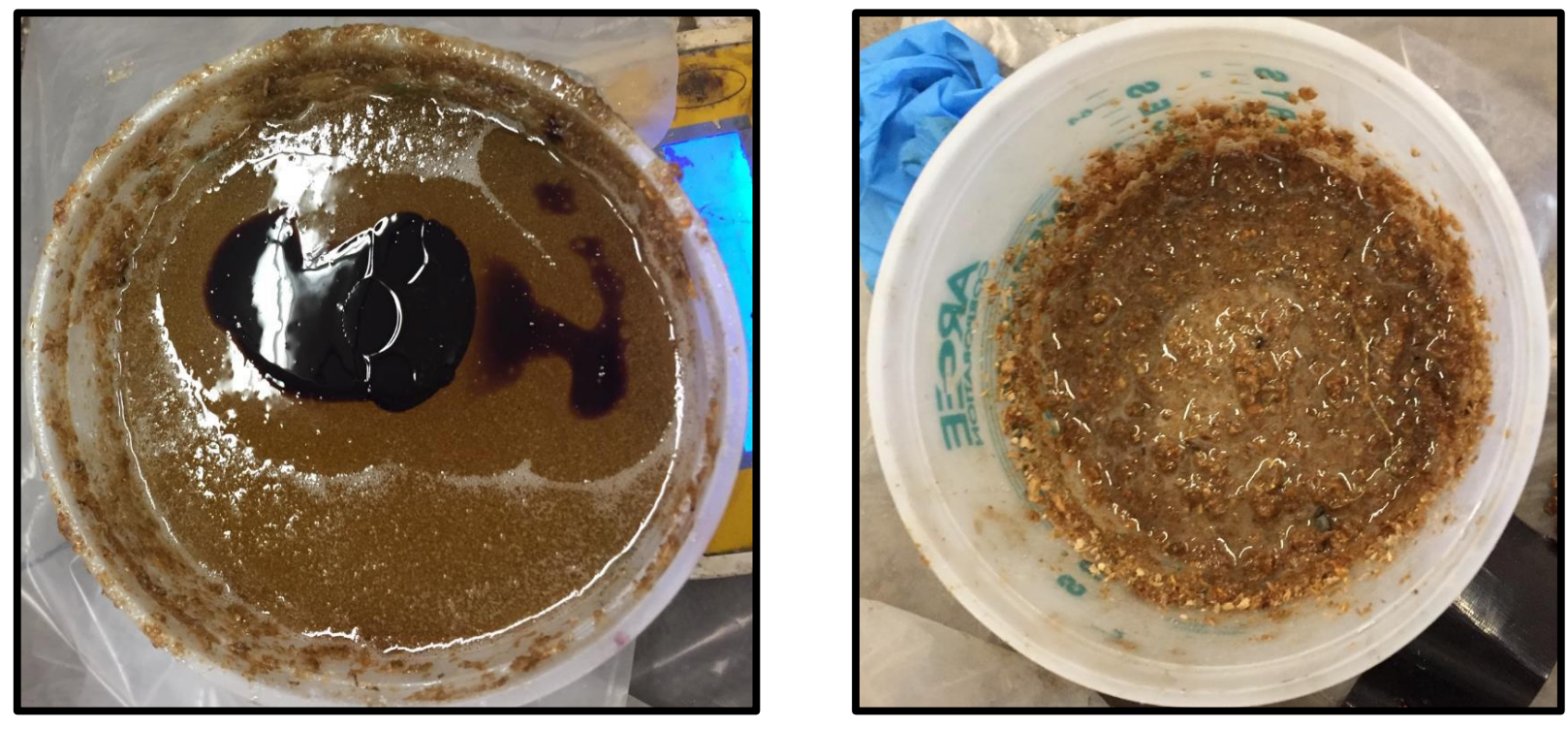

Figure 3.14: On left is a mixture of Hetron-D, MEKP, Cobalt Napthenate and left is a mixed resin and wood 

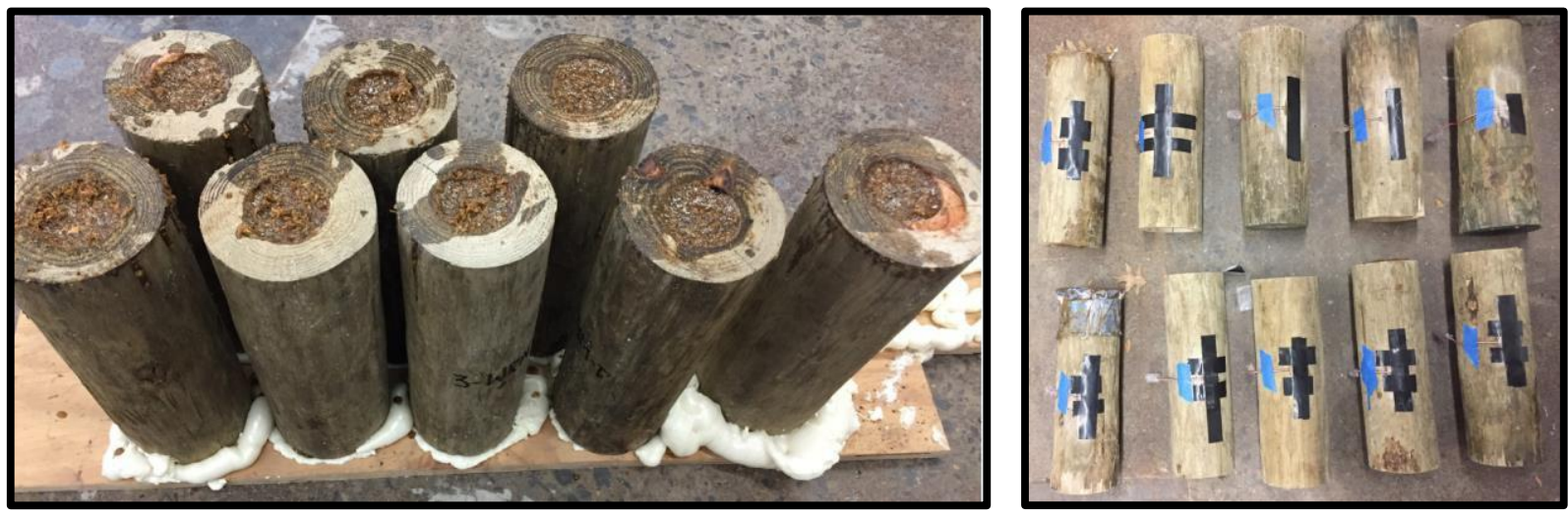

Figure 3.14: Resin filled cylinders along with strain gages attached

\section{Bonding FRP}

The CFRP wrap has a working life of two hours and is cut into required lengths depending on the number of layers and perimeter of the cylinder. Similar to bonding of FRP on beams is the wrapping of cylinders. Two part Sikadur-340 is mixed thoroughly according to manufacturer ratio and applied over the outer perimeter of the cylinders. The cut FRP is wrapped tight around the cylinders making sure that there are no voids, undulations over the surface such that complete

confinement is achieved by utilizing 100\% FRP's strength. An anchoring length/overlap of four inch is provided to attain a good overlapping bond which eliminates probable rip off FRP.

GFRP aqua wrap has a working life of 30-60 minutes and a shelf life of one year. This is a water activated wrap and requires no primer for bonding. Stricter banding wrapped around GFRP wrap helps it in confining and develops a good bond within GFRP. Strain gages are attached on the Timber and FRP materials along the axial and hoop directions to measure the variation in strains at the same instant of loading. The strain gage on the FRP allows to figure out its contribution in restraining the material before failure.

\section{Wrapping of cylinders:}



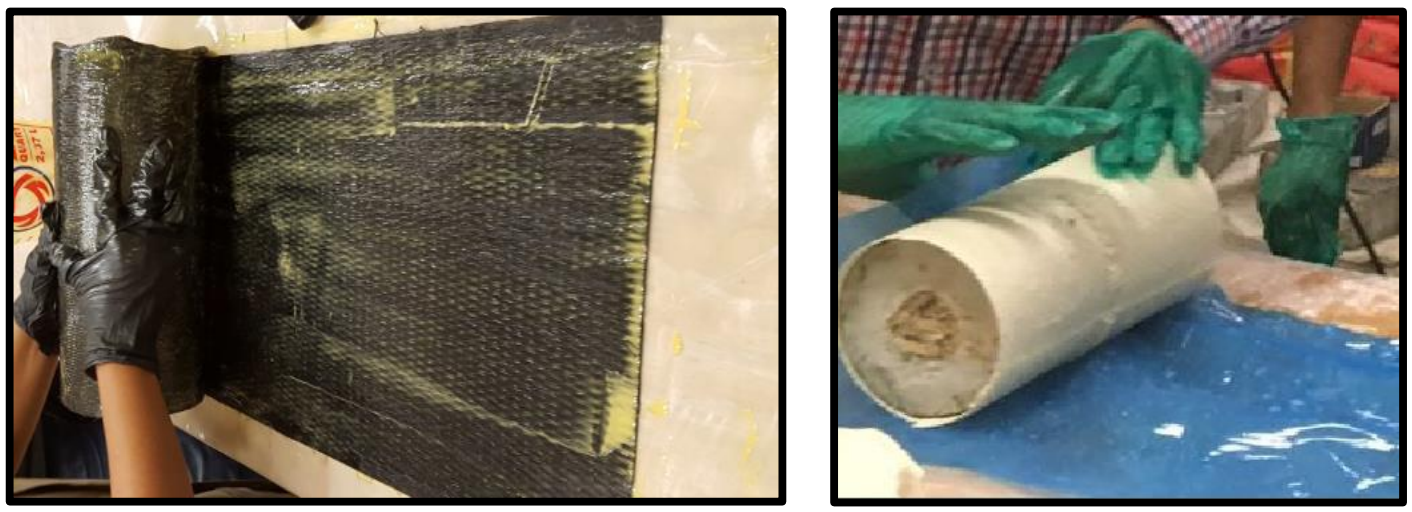

Figure 5.15: Wrapping of timber cylinders with Carbon and Glass FRP

\subsubsection{Test Set-up and Test procedure}

All the unwrapped and wrapped cylinders with strain gages at appropriate locations are tested in compression under INSTRON testing machine with a capacity of $224 \mathrm{kip}$. The loading is applied at a rate of kip/mm and the strains are documented at a constant load interval (stress controlled test). Load, deflection and strain are measured using data acquisition. The samples are loaded until failure to determine/understand the failure pattern, confinement effect and strength enhancement with number of layers.

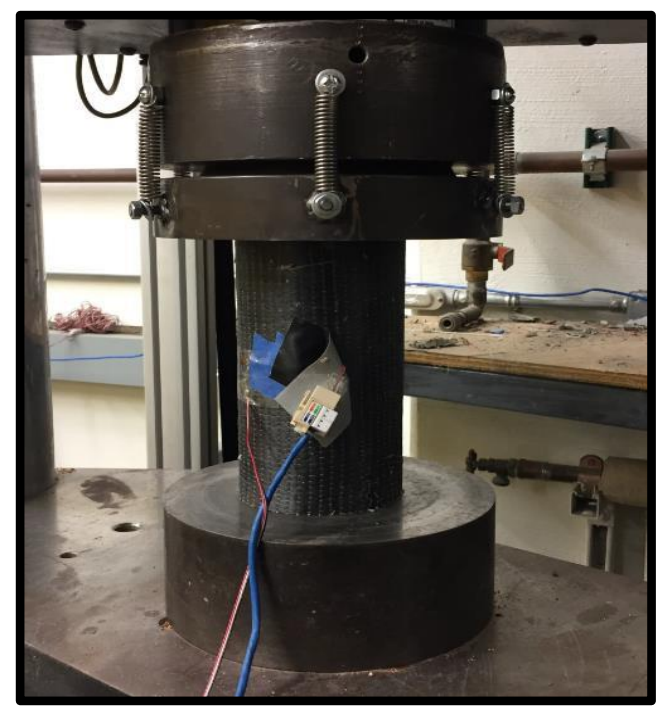

Figure 3.16: Test set up for compression testing of timber cylinders 


\section{Chapter 4. FRP Bridge Deck Test}

\subsection{General}

Bridge decks are designed to take vehicular, pedestrian, wind and snow loads, impact loads etc in general. Understanding the behavior of FRP bridge decks and its elements (coupons) experimentally and analyzing the results is the primary focus of this chapter. This chapter also comprises of several tabulated values, graphs, and necessary explanations relating to deck elements. Emphasis is on Load-Deflection curves and understanding the importance of stiffness of the components, strains at various locations, and type of failure is critical. Any additional findings deduced out of the available results are also clearly postulated.

Unlike steel, FRP is brittle and never exhibits any signs of yielding at ultimate loads. It failure is catastrophic and doesn't give any prior indications. FRP'S most common failures are delamination, de-bonding, buckling, fiber splitting, rupture and fiber pull out. Materials like FRP's which are a composition of Fibers and Resin and its strength being mainly governed by fibers alone, makes it difficult to predict the strength and ends up in over-designing or catastrophic failures. The table below comprises of all the summarized test data;

Table 4.1: Summary of various elements tested in an FRP deck

\begin{tabular}{|c|c|c|c|c|}
\hline Specimen & Type & Dimensions & $\begin{array}{c}\text { Maximum } \\
\text { Load } \\
\text { (lbs.) }\end{array}$ & Ultimate Stress/Strain \\
\hline FRP Bridge & Deck & $48.0 " x 10.25 " \times 3.5 "$ & 12571 & $3737.3 \mathrm{psi} / 4003$ ? \\
\hline \multirow{4}{*}{ Tension Test } & Longitudinal & 14.0"x1.0"x0.313" & 20261.89 & \\
\hline & & & & מים \\
\hline & Lateral & 10.0"x1.0"x0.313" & 1821.462 & \\
\hline & Web & 14.0"x1.0"x0.098" & 358.018 & - \\
\hline Bending Test & $(\mathrm{C} / \mathrm{S})$ & $10.25 " x 1.0 " \times 3.5 "$ & 330.029 & $98.11 \mathrm{psi} / 9679.8$ ?? \\
\hline
\end{tabular}




\subsection{FRP Bridge Deck}

\subsubsection{Bridge Deck Specimen}

The Bridge Deck Specimen is manufactured by Composite Advantage with dimensions 48.0" X 10.25" $\mathrm{x}$ 3.50". This simply supported deck with a span of 40.0 " is tested in three point bending to failure. This is a foam sandwiched beam with two flanges at top and bottom and webs joining both the flanges and run all the way through the length.

The experimental set up is similar to what is mentioned in the previous chapter. The load is applied until significant strains are developed and continued until the deck fails. The results obtained from data acquisition include load applied, strains developed and displacement occurred at the center of the span.

Table 4.2: Summary of the test result for FRP Bridge deck sample

\begin{tabular}{|l|c|}
\hline \multicolumn{1}{|c|}{ Description } & Values \\
\hline Dimension of the Deck & $\begin{array}{c}48.0 \text { "x10.25"x3.5 } \\
0 \text { ” }\end{array}$ \\
\hline Span of the Deck & 40.0 " \\
\hline Ultimate Load Capacity & $12571 \mathrm{lbs}$. \\
\hline Deflection at Maximum Load & 0.531 " \\
\hline Maximum Longitudinal Strain on Tension flange & $4003 \mathrm{in} / \mathrm{in}$. \\
\hline $\begin{array}{l}\text { Maximum Longitudinal Strain on Compression } \\
\text { Flange }\end{array}$ & $2607 \mathrm{in} / \mathrm{in}$. \\
\hline Maximum Lateral Strain on Tension Flange & $1034 \mathrm{in} / \mathrm{in}$. \\
\hline Maximum Lateral Strain on Compression Flange & $1072 \mathrm{in} / \mathrm{in}$. \\
\hline Shear Strain on the Web & $1418 \mathrm{in} / \mathrm{in}$. \\
\hline Shear stress in the Web & $4300 \mathrm{psi}$ \\
\hline
\end{tabular}

Figure 4.1 below shows a plot between Load and Deflection measured at mid-span for the FRP Bridge Deck Specimen. This graph is a measure of Flexural stiffness, and remains to be a straight line which indicates no loss of stiffness (constant) till the ultimate load of 12.571kips is reached. 
In case of FRP members, there is no characteristic post-peak behavior which indicates its brittleness and sudden catastrophic failure. The reduction in stiffness resulted due to web debonding at top and bottom flanges. The de-bonding is predominantly due to buckling of webs. The maximum deflection recorded at the mid span is 0.53 " at maximum load of 12.571 kips.

The specimen produced sound of fibers splitting and delamination of inner surface layers at both top and bottom flanges at 9.671 kips and deflection of 0.408 ". A loud popping sound is heard at maximum failure load.

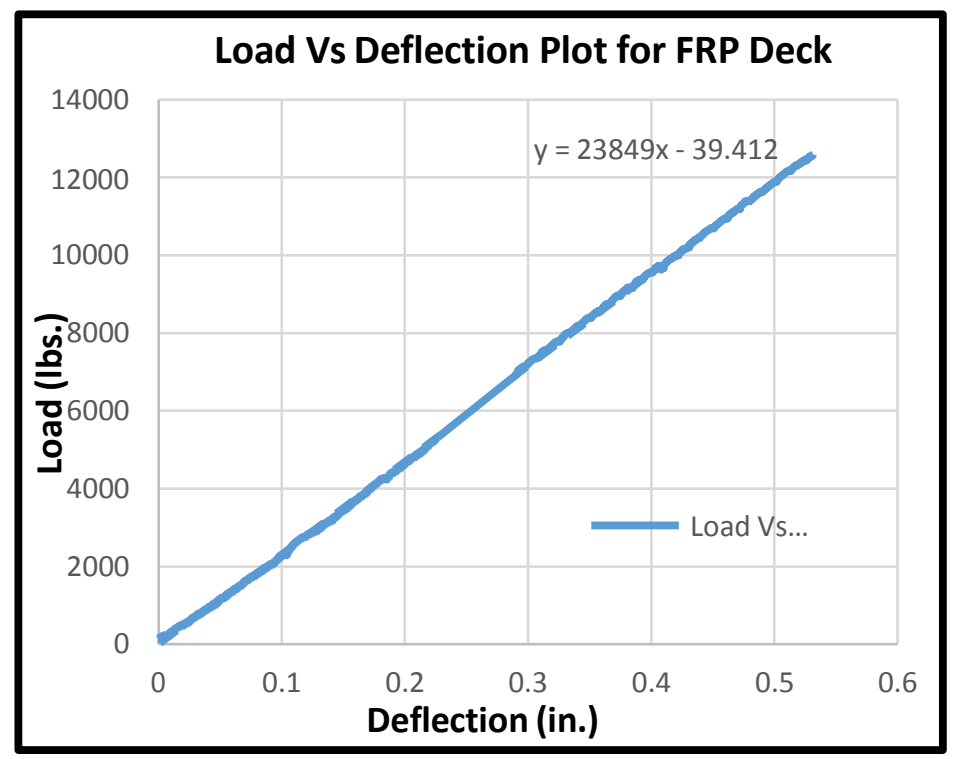

Figure 4.6: Load Vs Deflection plot for FRP bridge deck test in 3 point bending

The strains measured from both the top and bottom flanges at various loads are plotted in the graph below. The loads and strains are linear until the ultimate load. Strains on top and bottom flange are linear with the load till ultimate strains of 4003 in/in. (tension) and 2607 in/in. (compression) respectively. Once the capacity of the deck is reached, it can't brace no more load and the strains drop quick tending to zero.

Flexural stiffness (EI) for the FRP deck is determined to be $0.031 * 10^{9}-i^{2}$ from the deflection equation for 3 point bending mentioned below. 


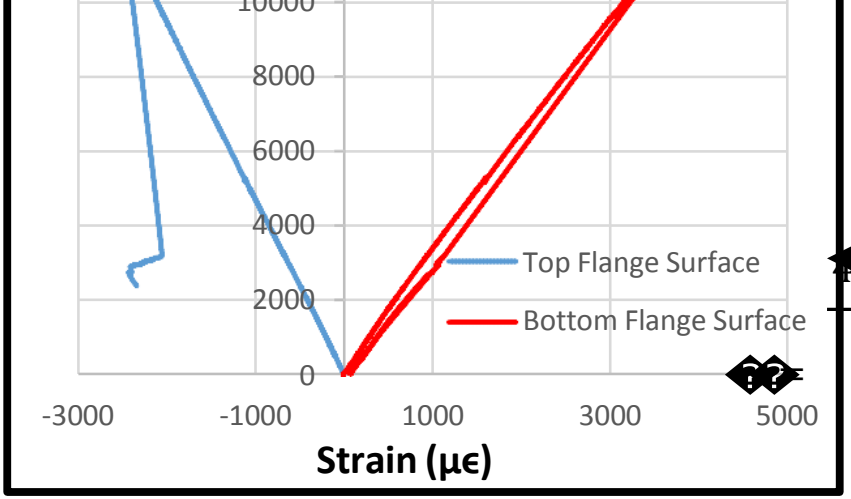

Figure 4.2: Load Vs Strain in top and bottom flange (le

Tlige (right) for FR $10^{6} \mathrm{psi}(7.86 \mathrm{GPa})$ for FRP Deck Sample. The Stress strain, till 3017.04 psi at a load of $12571 \mathrm{lbs}$. The st of load application.

Ton fright) for FRP

Tôn (right) for FRI beginning of rupture, splitting of fibers followed by delamination of few oyteratiay(rere) in the region

\section{FRP Deck}

3000

政

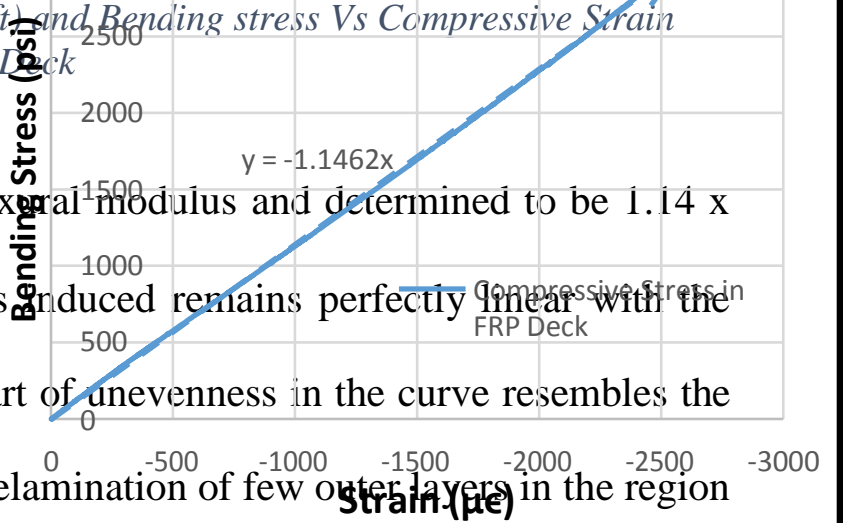
strain, till 3017.04 psi at a load of $12571 \mathrm{lbs}$. The start of anevenness in the curve resembles the 


\subsubsection{Modes of failure in Deck}

FRP Bridge Sample tested in three-point bending failed at $12571 \mathrm{lbs}$. with a loud popping sound. The predominant failure was web separation with local buckling near top and bottom Web-Flange junction. The foam in the sandwich deck is removed to understand the actual failure and it was clearly noticed that webs that connect the flanges buckled and separated from the flanges. In addition to this delamination between layers of flanges is clearly seen in the Figure 4.3 below.
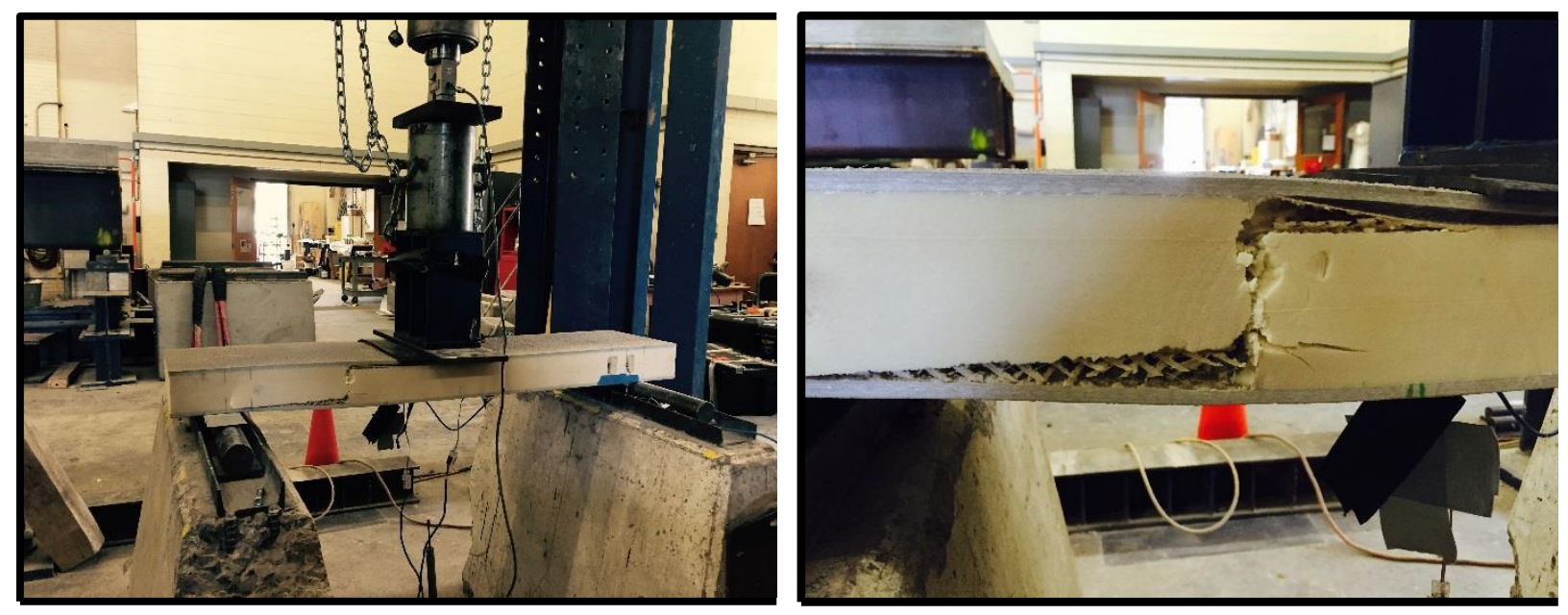

Figure 4.3: FRP Deck tested in 3 point bending (left) and close view of failure region in the deck (right)

\subsection{Numerical Analysis of the FRP Deck:}

Theoretically obtained values of deflection from the FRP deck are validated with the numerical results obtained from Finite Element Analysis. ANSYS APDL 16.0 is a linear, non-linear and dynamic structural analysis software used in modelling the FRP deck. 


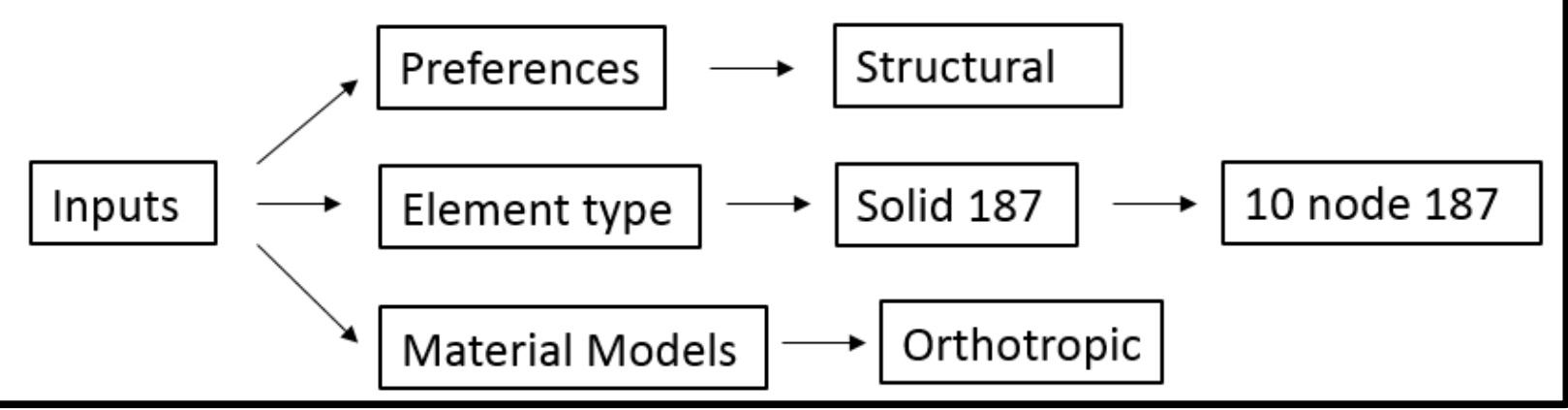

Figure 4.4: Flow chart describing various steps in modelling the deck
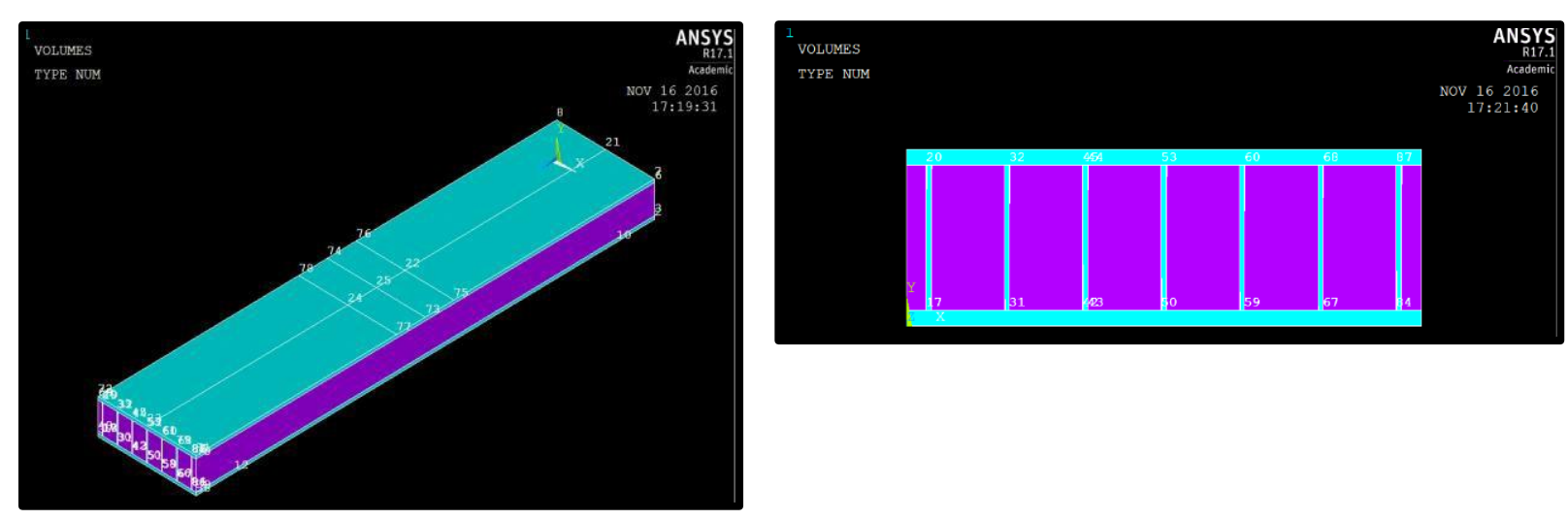

Figure 4.5: Elements and nodes of the model (left) and cross-sectional view of the model in ANSY

Table 4.3: Comparison of experimental and FE results for the FRP deck

\begin{tabular}{|c|c|c|}
\hline Parameter & Experimental & FE \\
\hline Load (lbs.) & 12571 & 12571 \\
\hline Deflection(in.) & 0.526 & 0.455 \\
\hline Compressive strain & 2607 & 2700 \\
$(\mu \epsilon)$ & & \\
\hline Tensile strain $(\mu \epsilon)$ & 4003 & 2806 \\
\hline
\end{tabular}




\begin{tabular}{|c|c|c|}
\hline Compressive stress & 13468.37 & 16572.6 \\
$(\mathrm{psi})$ & & \\
\hline
\end{tabular}

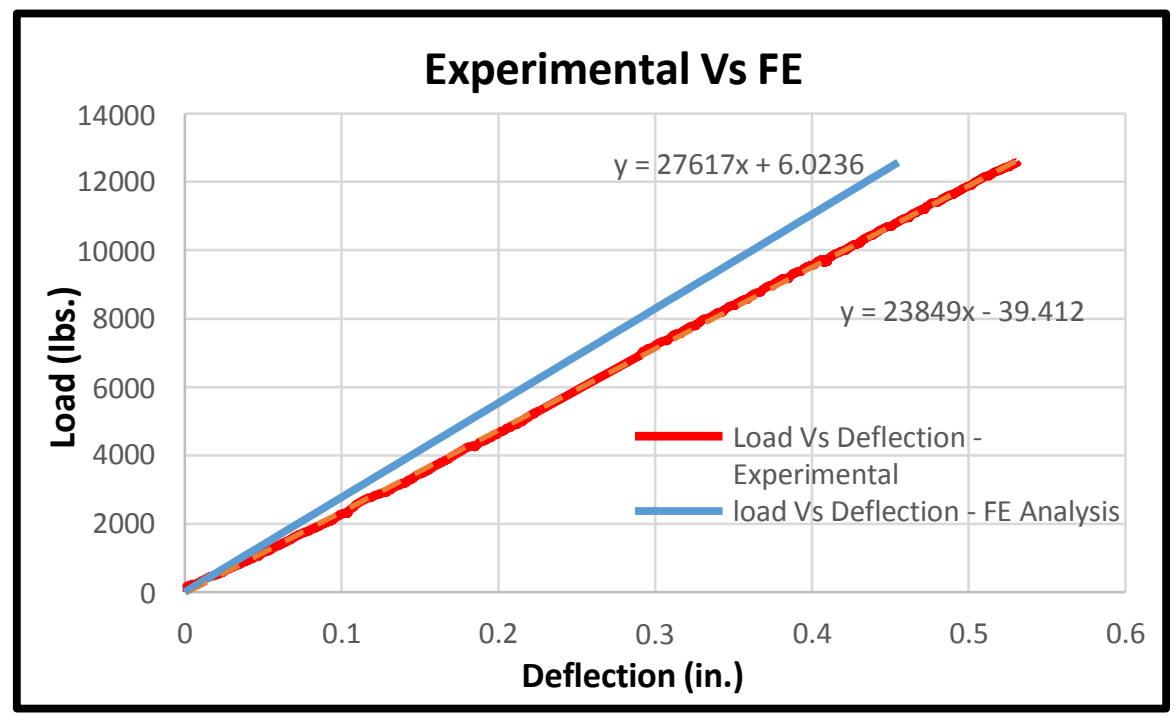

Figure 4.6: Load Vs Deflection plot for comparing experimental and FE results of FRP deck

From the graph it is clear that the experimental and theoretical deflections vary by $13 \%$ which means FE model is little stiff than the actual specimen. The $\mathrm{P} / \delta$ for the FE model is 27617 lbs. /in. and experimentally gave $23849 \mathrm{lbs}$. /in.

\section{Post processing results:}

Stress in tension is determined to be $16022.4 \mathrm{psi}$ and strain is determined to be 0.0028 micro strains
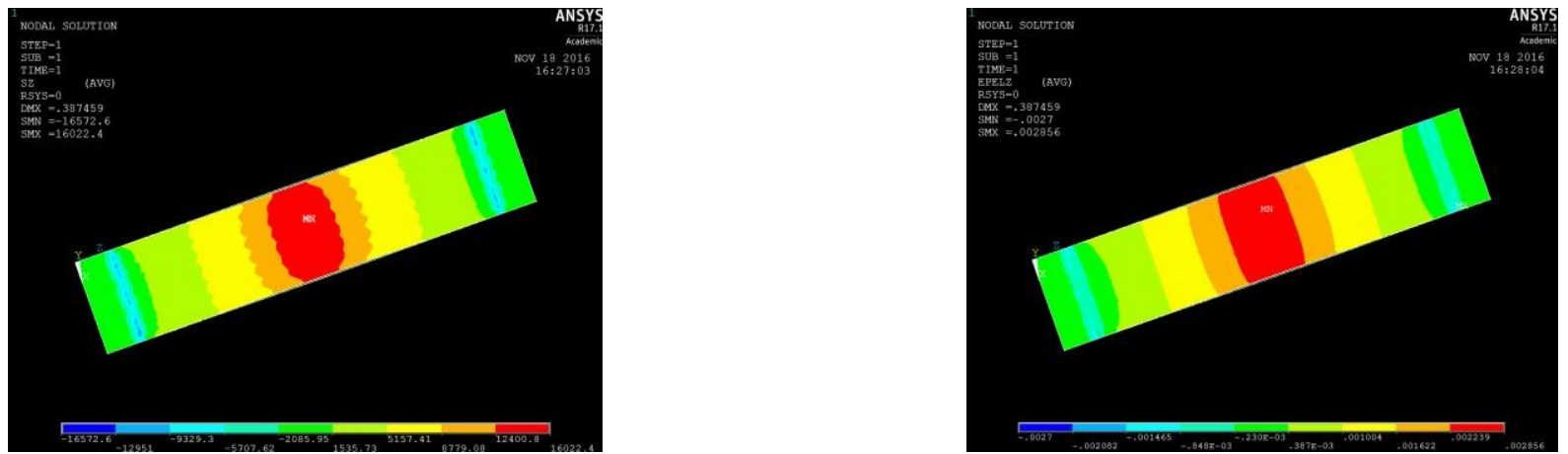

Figure 4.7: Stress and strain plot for FRP bridge deck in ANSYS 


\subsubsection{Failure Mode determination}

\section{Check for Bending Stress}

From theory of simple bending, a relationship between bending moment on a section of a beam and the normal stress developed in a particular layer of the beam is derived. IT also describes the flexural formula, a relationship between bending moment, normal stress and second moment of area. The equation is as follows;

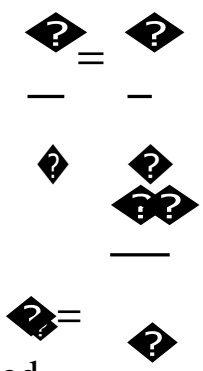

Where $\mathrm{M}$ is the maximum moment developed $\mathrm{y}$ is the half the depth of the sample

I is the moment of inertia of the sample

The maximum bending stress of the FRP deck is determined to be 3013.59 psi

Experimentally, bending stress to failure is determined by Elastic modulus * tensile strain of the coupon. The tensile strain of the coupon is obtained to be $14548.16 \mu \epsilon$. Bending failure stress of the FRP Deck is obtained by introducing knock down factor of 0.6 and a stress concentration factor of 0.6 which brings strain from $14548.16 \mu \epsilon$ to $5237.33 \mu \epsilon$. The stress required to fail the sample in bending is obtained to be $21.5 \mathrm{ksi}$.

\section{Check for Web Shear}

Shear stress in any beam can be obtained from the very basic equation which is:

For a rectangular section this takes a form;

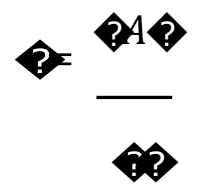




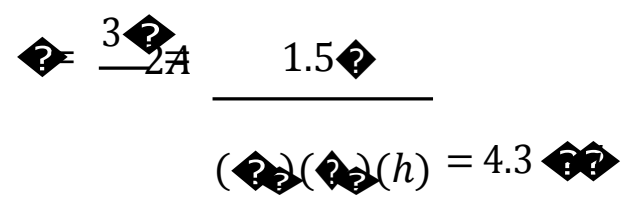

In case of $\mathrm{W}$ or $\mathrm{S}$ sections, the thickness of the flange is much higher than the web thickness, hence the effect of shear stress in flanges is neglected.

\section{Check for Web buckling}

Web buckling is one of the most frequently observed failure modes in the webs of wide flange sections, channel sections, C-sections etc. web buckling may be few types' namely local, distortion and Euler's buckling. In this work we only deal exclusively with Euler's buckling which is the reason for flexural buckling, flexural-torsional buckling, and lateral-torsional buckling.

The concept of slenderness comes into play when buckling of the web is considered. The more slender the beam is, the more is its susceptibility to local or global buckling failure. Local failure in the web is also called as web crippling. If the slenderness is too low, there is other failure mode called crushing which predominates.

The buckling load for the FRP deck is calculated by using the equation:

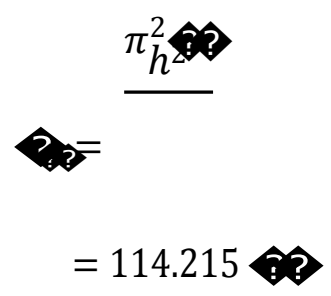

Where

$\mathrm{E}=$ Elastic modulus for web material

$\mathrm{I}=$ Moment of inertia for the web

$\mathrm{h}=$ height of the web from center of top flange to bottom flange 


\subsection{Tension Tests on Coupons}

\subsubsection{Longitudinal Coupons}

Tensile modulus or Elastic modulus of the composite under tensile load is analyzed from Stress Vs Strain plot. The Elastic modulus is deduced from the slope of linear part of the curve which is

\subsection{6 if this coupon.}

The Stress Vs Strain curve for composites under tensile loading may be bilinear (two slopes) or trilinear (three slopes). Thus the modulus is determined from these slopes and the point where the slope of the curve gets altered is called bifurcation point. There may be a couple of bifurcation points in any Stress- Strain curve that control the tensile modulus value.

Tensile Stress $(\mathrm{psi})=$ Tensile Load/Cross-sectional area

Where,

$\mathrm{P}=$ Tensile Load applied on either sides simultaneously (lbs.)

$\mathrm{T}=$ Thickness of the coupon (in.)

$\mathrm{W}=$ Width of the coupon (in.)

$\mathrm{E}_{1}=$ Elastic modulus of the composite till the first bifurcation point

$\mathrm{E}_{2}=$ Elastic modulus of the composite starting from first bifurcation till the second bifurcation point

Three coupons each of 14.0" in length and cross-sectional dimensions of 1.0" $0.313^{\prime \prime}$ are tested in longitudinal direction. A typical stress strain curve is plotted for the tested composite and the

values of maximum stress, strain and load are determined along with the tensile modulus and presented in the table below. It can be inferred from the plot that it is bi-linear and the maximum

stress measured 64.7 and the corresponding strain is read to be 14548 


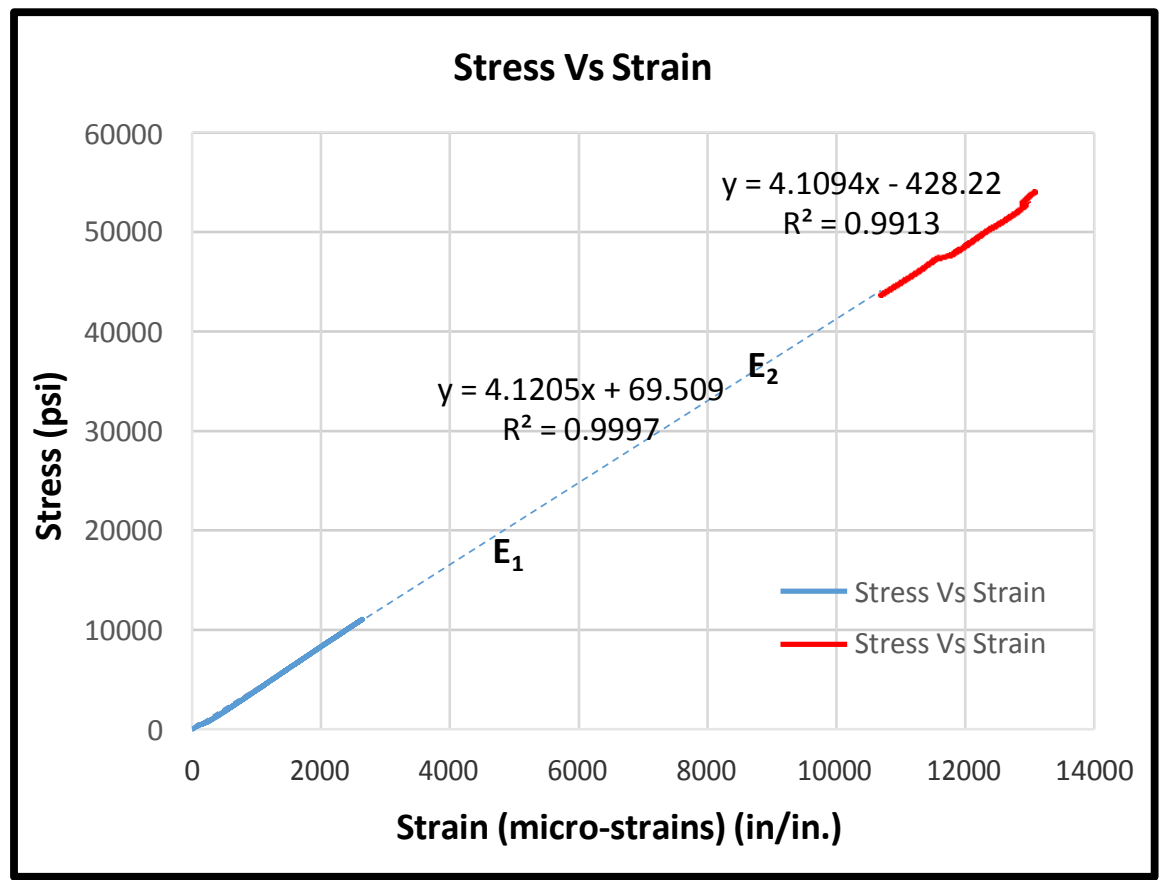

Figure 4.4: Stress Vs Strain plot for the longitudinal coupon tested in tension
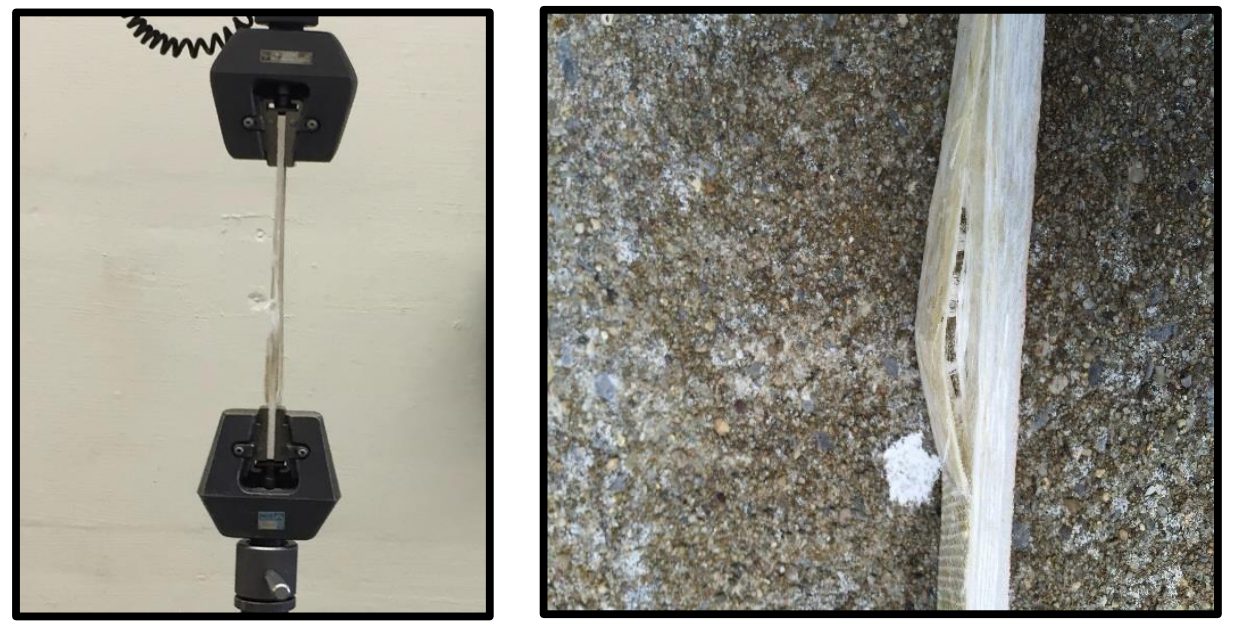

Figure 4.5: Tension coupon with failure at the middle third zone

Table 4.4: Tabulated results for the coupons tested in tension

\begin{tabular}{|c|c|c|c|c|c|c|c|c|c|}
\hline Sample & $\begin{array}{c}\text { Maximu } \\
\text { m Load } \\
\text { (lbs.) }\end{array}$ & $\begin{array}{l}\text { Stress at } \\
\text { Maximu } \\
\text { m Load } \\
\text { (psi) }\end{array}$ & $\begin{array}{l}\text { Strain at } \\
\text { Maximu } \\
\text { m Load } \\
(\mu \varepsilon)\end{array}$ & $\begin{array}{l}\text { Load at } \\
\text { Bifurcati } \\
\text { on Point } \\
\text { (lbs.) }\end{array}$ & $\begin{array}{l}\text { Stress at } \\
\text { Bifurcati } \\
\text { on Point } \\
\text { (psi) }\end{array}$ & $\begin{array}{l}\text { Strain at } \\
\text { Bifurcat } \\
\text { ion } \\
\text { Point } \\
(\mu \varepsilon)\end{array}$ & $\begin{array}{c}\mathbf{E}_{1} \\
(\mathrm{msi})\end{array}$ & $\begin{array}{c}\mathbf{E}_{2} \\
(\mathbf{m s i} \\
)\end{array}$ & $\begin{array}{c}\mathbf{E}_{1} / \mathbf{E} \\
2\end{array}$ \\
\hline $\begin{array}{l}\text { Longitudinal } \\
1\end{array}$ & 20261.89 & 64734.48 & 14548.16 & 13656.58 & 43631.26 & $\begin{array}{c}10690.2 \\
3\end{array}$ & 4.120 & $\begin{array}{c}4.10 \\
9\end{array}$ & $\begin{array}{c}1.00 \\
2\end{array}$ \\
\hline
\end{tabular}


The change of slope first occurred at about $67 \%$ of the ultimate stress and the ratio of change of

slopes is calibrated as 1.002. Alterations in Elastic modulus of the composite coupon tested in tension might may be due to initiation of fiber rupture or splitting, development of micro-cracks,

or matrix softening.

Finally, failure mode in the coupon can be concluded by visually comparing the sample to the standards mentioned in ASTM D 3039 as DGM which is Delamination Gauge Middle.

\subsubsection{Lateral Coupons}

Tensile modulus of 10.0 " long coupons with the cross-sectional dimensions of 1.0 " 20.313 " is determined. Similar to longitudinal coupons, Stress-Strain curve is plotted for Lateral coupons to

determine the Elastic modulus in transverse direction.

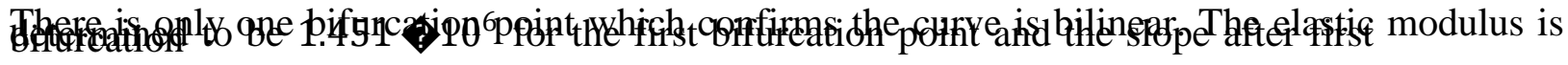
paint is $848.810^{6}$ The maximum stress is 5819.371 and corresponding strain is read to be
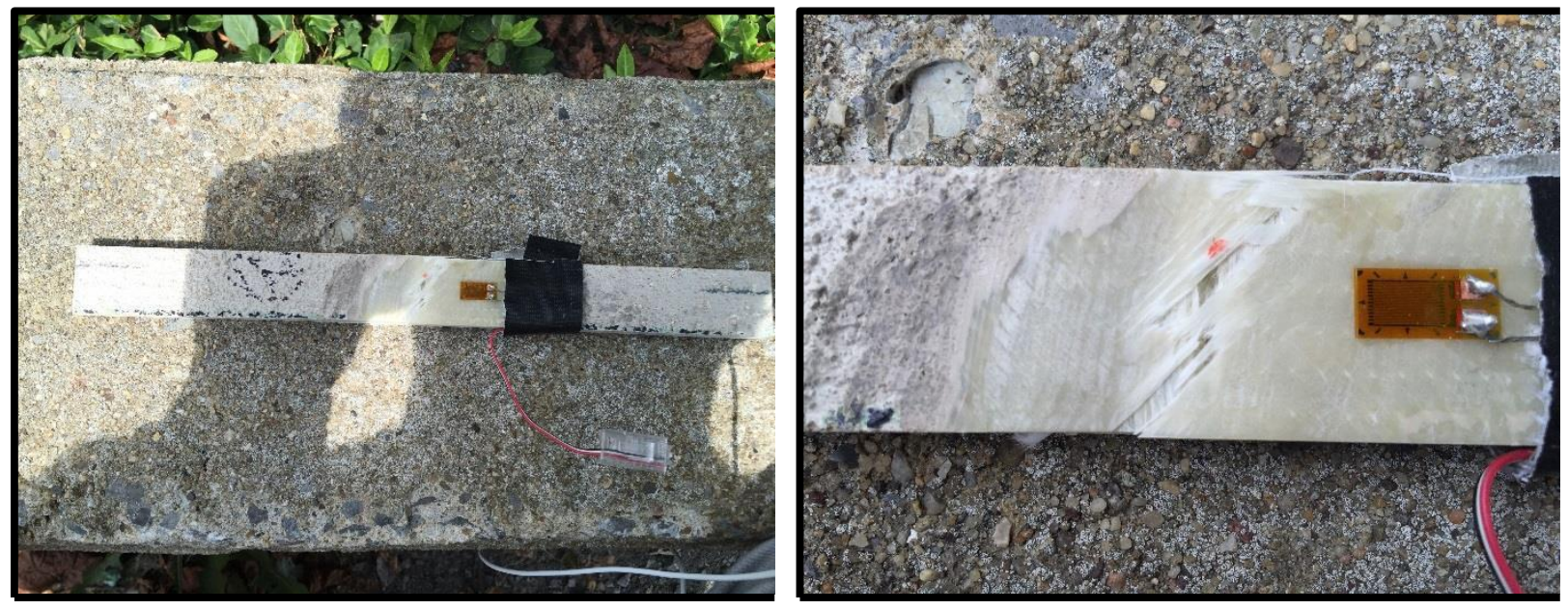

Figure 4.6: Tension tests on lateral coupon with failure in middle third zone 


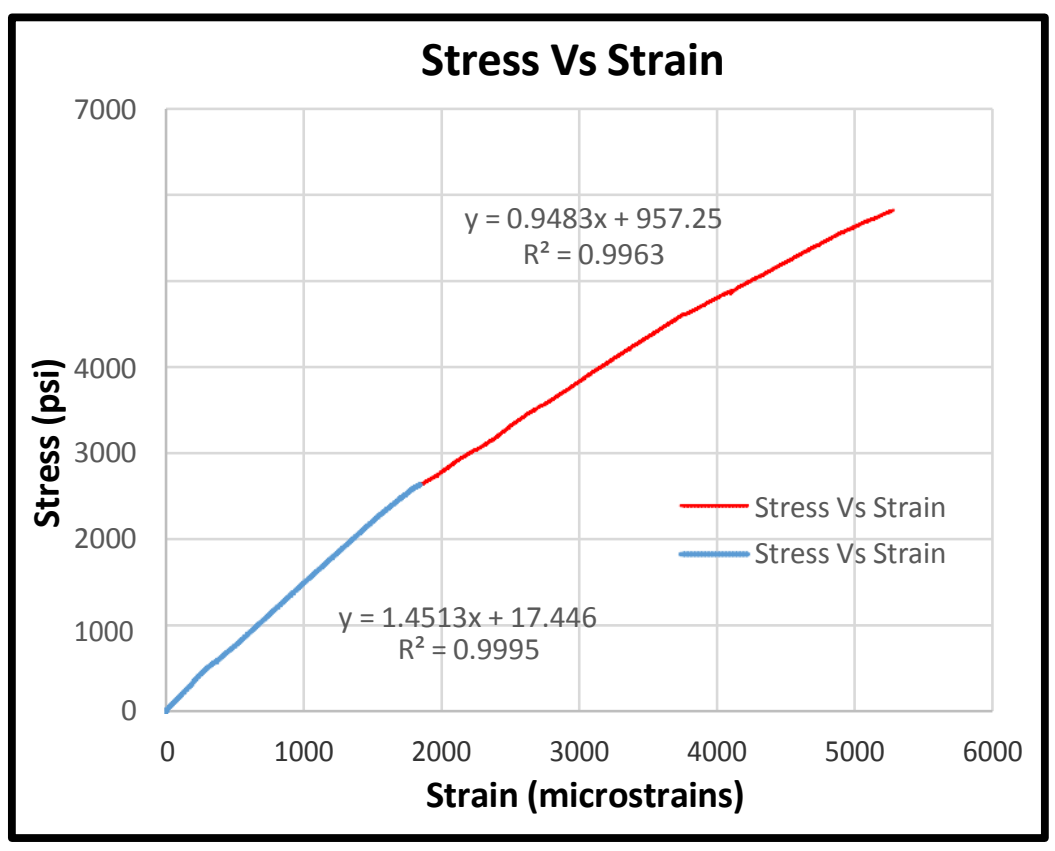

Figure 4.7: Stress Vs Strain plot for lateral coupon tested in tension

Table 4.5: Tabulated results for the lateral coupons tested in tension

\begin{tabular}{|c|c|c|c|c|c|c|c|c|c|}
\hline Sample & $\begin{array}{c}\text { Maximum } \\
\text { Load } \\
\text { (lbs.) }\end{array}$ & $\begin{array}{l}\text { Stress at } \\
\text { Maximum } \\
\text { Load (psi) }\end{array}$ & $\begin{array}{l}\text { Strain at } \\
\text { Maximum } \\
\text { Load }(\mu \varepsilon)\end{array}$ & $\begin{array}{l}\text { Load at } \\
\text { Bifurcation } \\
\text { Point (lbs.) }\end{array}$ & $\begin{array}{l}\text { Stress at } \\
\text { Bifurcation } \\
\text { Point (psi) }\end{array}$ & $\begin{array}{l}\text { Strain at } \\
\text { Bifurcation } \\
\text { Point }(\mu \varepsilon)\end{array}$ & $\begin{array}{c}\mathbf{E}_{1} \\
(\mathrm{msi})\end{array}$ & $\begin{array}{c}\mathbf{E}_{2} \\
\text { (msi) }\end{array}$ & $\begin{array}{l}\mathbf{E}_{1} / \\
\mathbf{E}_{2}\end{array}$ \\
\hline $\begin{array}{l}\text { Lateral } \\
1\end{array}$ & 1821.463 & 5819.371 & 5280.688 & 719.490 & 2628.821 & 1846.093 & 1.451 & 0.948 & 1.530 \\
\hline
\end{tabular}

The change of slope occurred at a value 45.1\% \%of the ultimate stress. and the ratio of change of reduction in stiffness values for lateral composite specimen leads to an understanding about the fiber architecture and direction of lay-up.

In this set of coupons, the fiber orientation is expected to be in a direction normal to the length. This can be supported by the fact that, fibers in a direction normal to the direction of load do not contribute for any strength and is substantiated when the experimental tests showed the coupon 
can resists only about 1821.463 ? 3 before failure which is very negligible. This concludes that composite fibers are all running in the longitudinal direction of the bridge deck and negligible

fibers in the lateral direction.

\subsection{Bending Tests}

Bending tests are carried out to determine the bending strength, bending stiffness, to have a little closer look at the bending failure mode and understand it in a little better way.

Bending Stress $\left(\mathrm{f}_{\mathrm{b}}\right)$ is theoretically calculated from the equation of Theory of Bending. It is as follows;

Bending stress is usually derived from:
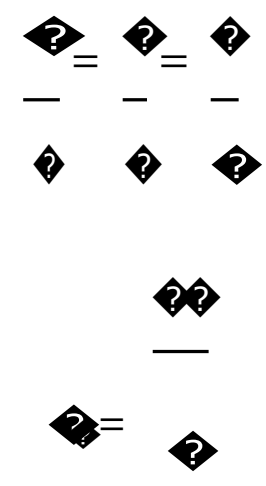

Where,

$\mathrm{M}=$ Bending Moment (kips-ft. or lbs.-in)

$\mathrm{c}=$ Distance of neutral axis from outer most fibers (in.)

$\mathrm{I}=$ Moment of Inertia $\left(\mathrm{in}^{4}\right)$

Bending modulus from four-point loading can be calculated based on slope from Stress- Strain curve. Theoretical value of bending modulus is calculated from

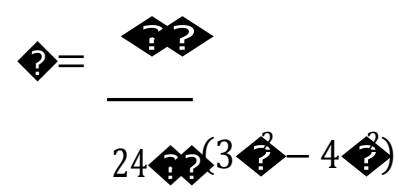

Based on three-point loading, theoretical bending modulus determined by using:

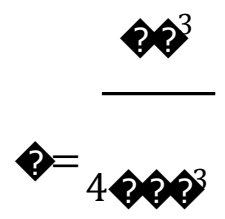


The bending strength is calculated as $\frac{P}{}$ for 4-point bending load and $\frac{3 P}{}$ for 3-point bending load.

$\mathrm{P}=$ Maximum Load (lbs.)

$\mathrm{L}=$ length of the span (in.)

$\mathrm{b}=$ width of specimen (in.) and $d=$ thickness of the specimen (in.)

\subsubsection{Bending Tests on Cross-Section Sample of Bridge Deck}

A cross-sectional sample cut from the deck with dimension 10.25 " 1.0 " $3.5^{\prime \prime}$ is loaded in 3 point bending to analyze the bending phenomenon, influence of buckling on the webs and

structural performance of the deck taking all the effects into account.

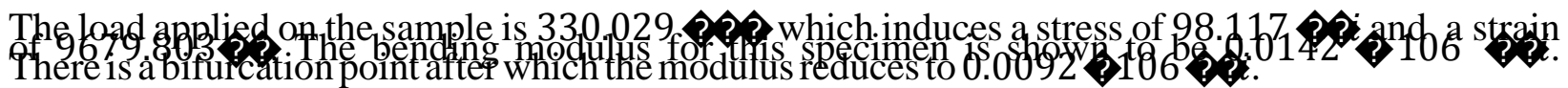

After application of load the webs tried to buckle and a stage occurred when the sample started

giving up and didn't take any more load to test it till failure. After test, when the sample is closely examined the buckling has an effect at the web-flange junction and also the webs buckled permanently and are seen to be out of plane.

Theoretically web is allowed to take a load of $114.21 ?$ and experimentally it takes a load of 330.029. So it has exceeded its capacity and hence can fail in by buckling. 


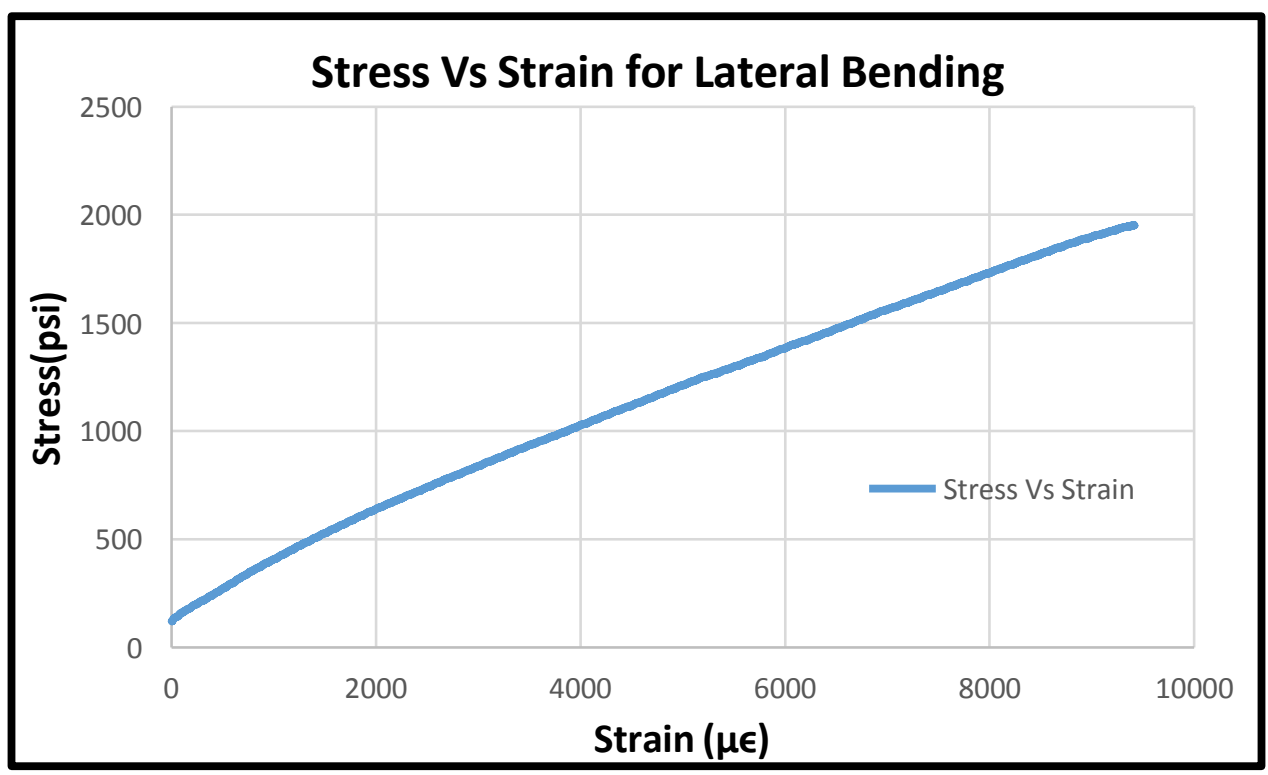

Figure 4.8: Stress Vs Strain plot for lateral bending of the section of the deck

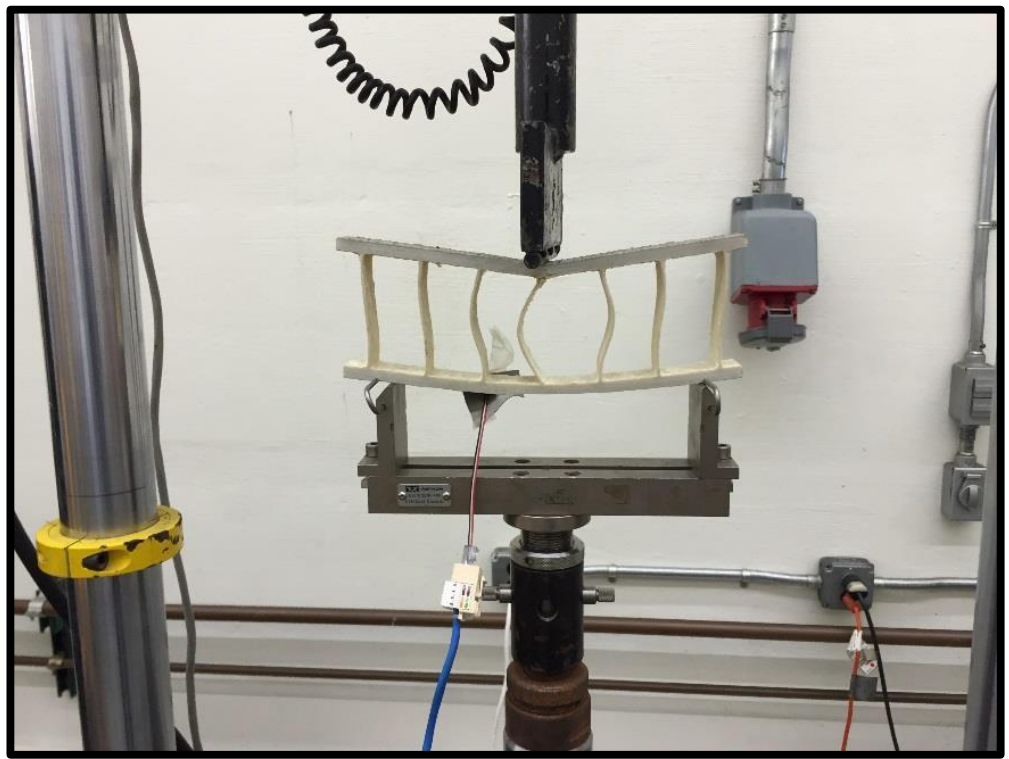

Figure4.9: Buckling of flanges in the cross-section element of the deck in 3-point loading 


\section{Chapter 5. AXIAL COMPRESSION TESTING OF FRP STRENGTHENED TIMBER CYLINDERS}

\subsection{Introduction}

Compression tests are conducted on Southern Pine timber cylinders of 4.0" x 8.0" with several variations like solid cylinders (control specimens), hollow (with different diameters), with a core drilled at the center, filler material at the center, wrapped with 1, 2 and 3 layers of unidirectional pre-impregnated Carbon fiber, Glass -Aqua wrap. Results of the compression tests on wrapped and no wrap cylinders are presented in this chapter. All the specimens are wrapped by hand and care is taken so that no damage or split of fiber occurs during handling and wrapping. The results from various configuration cylinders are tabulated in separate sections and conclusions are drawn at the end of this chapter.

\subsection{CFRP Cylinders}

\subsubsection{Effect of No. of CFRP Wrap Layers on Compression of Solid Timber Specimens}

Solid timber specimens with and without wrap are tested to understand the behavior of timber in axial compression and the strength enhancement provided by FRP in circumferential direction. The maximum axial load capacity and average stress for solid cylinders with and without wrap are reported in the Table 5.1 below. 
Table 5.1: Strength of wrapped and non-wrapped GFRP timber specimens in axial compression

\begin{tabular}{|c|c|c|c|c|c|}
\hline Specimen & $\begin{array}{l}\text { Max. axial } \\
\text { strength, } \\
\text { (kip) }\end{array}$ & $\begin{array}{l}\text { Avg. axial } \\
\text { strength, } \\
\text { (kip) }\end{array}$ & $\begin{array}{l}\text { Avg. increase in } \\
\text { strength per } \\
\text { layer } \\
\text { (kip) }\end{array}$ & $\begin{array}{l}\text { Avg. axial } \\
\text { stress, } \\
\text { (psi) }\end{array}$ & $\begin{array}{l}\text { Avg. \% } \\
\text { increase in } \\
\text { strength }\end{array}$ \\
\hline 4-S-0 & $\begin{array}{l}60.900 \\
72.768 \\
66.421 \\
\end{array}$ & 66.70 & - & 5055.91 & $\begin{array}{c}\text { Control } \\
\text { Specimen }\end{array}$ \\
\hline 4-S-C1 & $\begin{array}{c}- \\
77.75 \\
74.735\end{array}$ & 76.2 & 9.5 & 6706.202 & 14.25 \\
\hline 4-S-C2 & $\begin{array}{l}88.631 \\
75.749 \\
88.842\end{array}$ & 84.407 & 8.85 & 6716.922 & 26.5 \\
\hline 4-S-C3 & $\begin{array}{c}105.957 \\
91.029 \\
76.372 \\
\end{array}$ & 91.12 & 12.21 & 7241.497 & 36.6 \\
\hline
\end{tabular}

Solid timber cylinders wrapped with 1 layer of unidirectional carbon showed an average percentage increase in strength of $14.25 \%$ with respect to control specimen.

$>2$ and 3 layer wrapped timber specimens showed a percentage increase of $26.50 \%$ and $36.60 \%$ respectively, with respect to control specimen.

$>$ The average percentage increase in strength per layer for 1,2 and 3 layered specimens is $14.25 \%, 13.26 \%$ and $18.3 \%$ with respect to control specimen, respectively. Average percentage increase in strength for 1,2 and 3 layers of wrapping is shown in the Figure 5.1 below. 


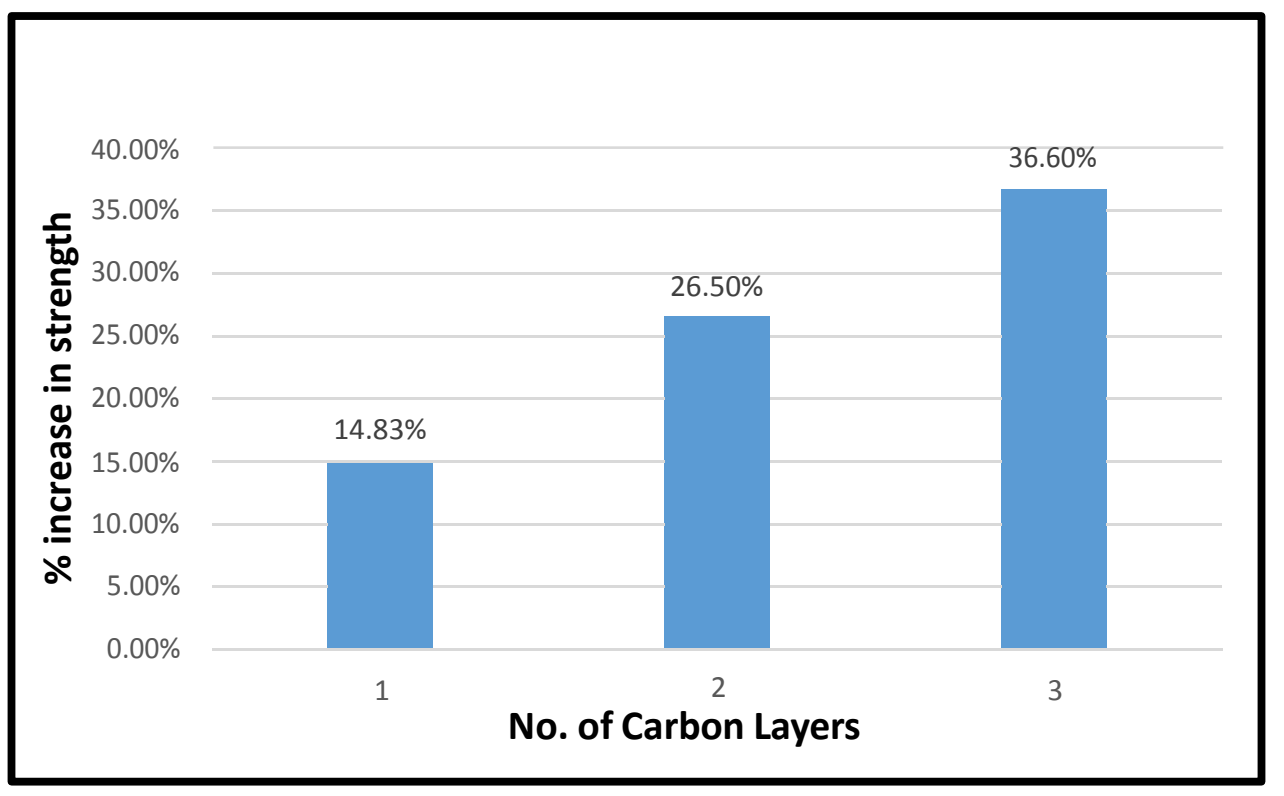

Figure 5.1: Average percentage increase in strength for 1,2 and 3 layered CFRP wrapped timber cylinders

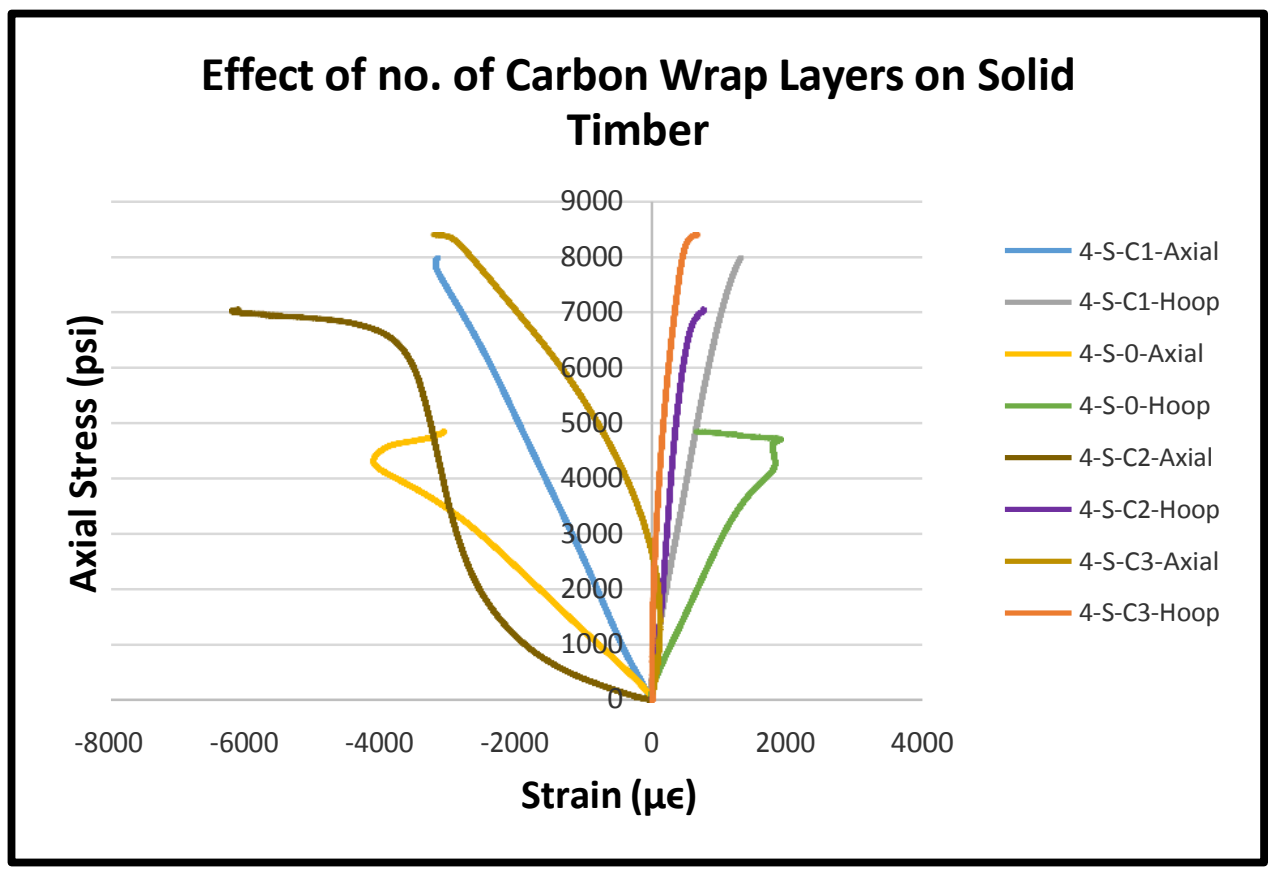

Figure 5.2: Comparison on effect of number of CFRP layers on timber cylinders 


\subsubsection{Effect of Section Loss on Compressive Strength of Timber Samples}

Timber specimens (4.0" x 8.0") are drilled at the center with core diameters 2.0 " and 3.0". A set of core drilled cylinders are filled back with a filler material (Chapter 3 explains details of specimen preparation). These set of samples are tested for maximum axial load capacity and stress for various configured without any wrap cylinders and are reported in the Table 5.2 below.

Table 5.2: Strength of core drilled and core filled timber cylinders tested in axial compression

\begin{tabular}{|c|c|c|c|c|}
\hline Specimen & $\begin{array}{l}\text { Max. axial } \\
\text { strength, } \\
\text { (Kip) }\end{array}$ & $\begin{array}{l}\text { Avg. axial } \\
\text { strength, } \\
\text { (Kip) }\end{array}$ & $\begin{array}{l}\text { Avg. axial } \\
\text { stress, } \\
\text { (Psi) }\end{array}$ & $\begin{array}{l}\text { Avg. \% } \\
\text { change in } \\
\text { strength }\end{array}$ \\
\hline 4-S-0 & $\begin{array}{l}60.9 \\
72.7 \\
66.4\end{array}$ & 66.7 & 5055.9 & $\begin{array}{c}\text { Control } \\
\text { Specimen }\end{array}$ \\
\hline $4-\mathrm{H} 2-0$ & $\begin{array}{l}50.912 \\
65.617 \\
58.533\end{array}$ & 58.354 & 6191.545 & -12.51 \\
\hline 4-H3-0 & $\begin{array}{l}40.706 \\
35.765 \\
41.983 \\
\end{array}$ & 39.484 & 7181.92 & -40.80 \\
\hline 4-H2F-0 & $\begin{array}{l}46.454 \\
57.859 \\
83.802 \\
\end{array}$ & 62.705 & 4989.905 & -5.99 \\
\hline 4-H3F-0 & $\begin{array}{l}60.815 \\
73.933 \\
71.446\end{array}$ & 68.731 & 5469.465 & +3.04 \\
\hline
\end{tabular}

Solid timber cylinders are compared with core drilled and filled specimens to understand their behavior under section loss.

Specimen with 2.0 " core has a $12.51 \%$ decrease in average compressive strength and a 3.0 " core has an average decrease of $40.80 \%$. 
2.0" core filled cylinders exhibit 5.99\% decrease in average axial strength and 3.0" cylinder shows $3.04 \%$ increase w.r.t to the solid cylinder.

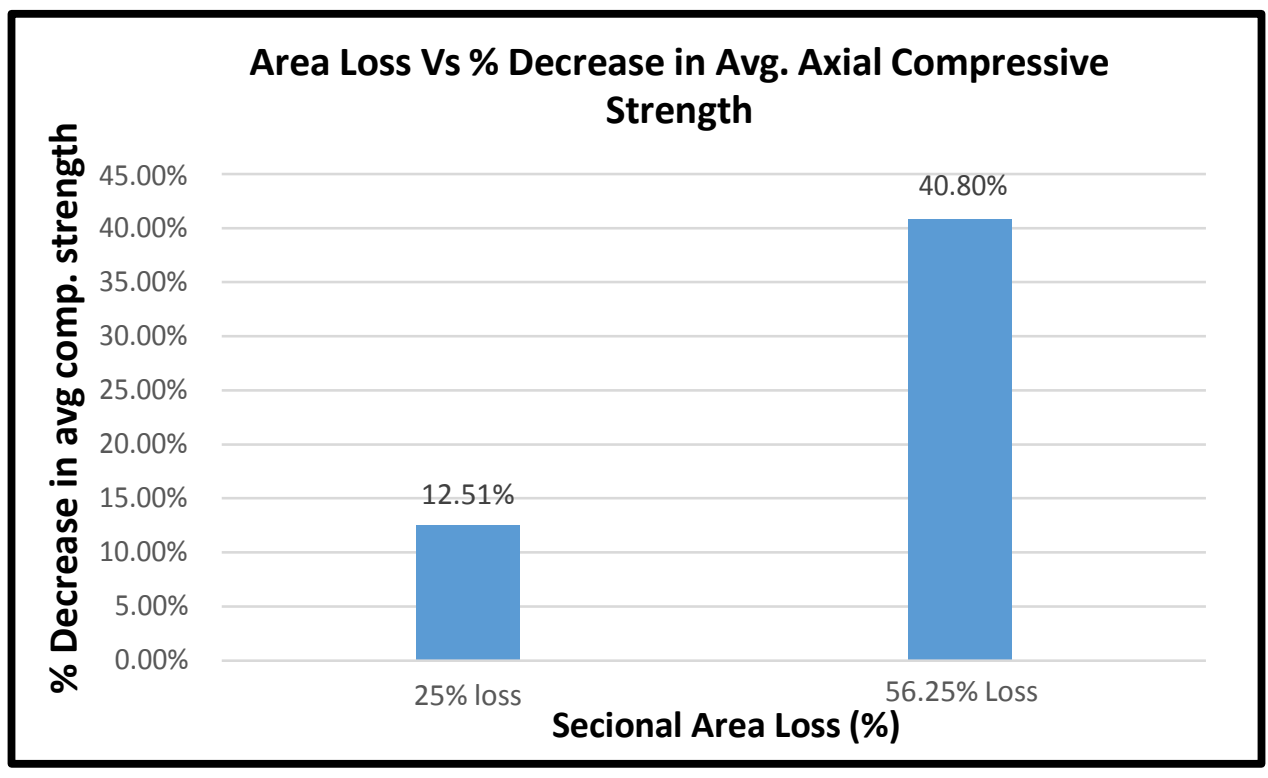

Figure 5.3: Comparison of section loss with \% decrease in average axial compressive strength

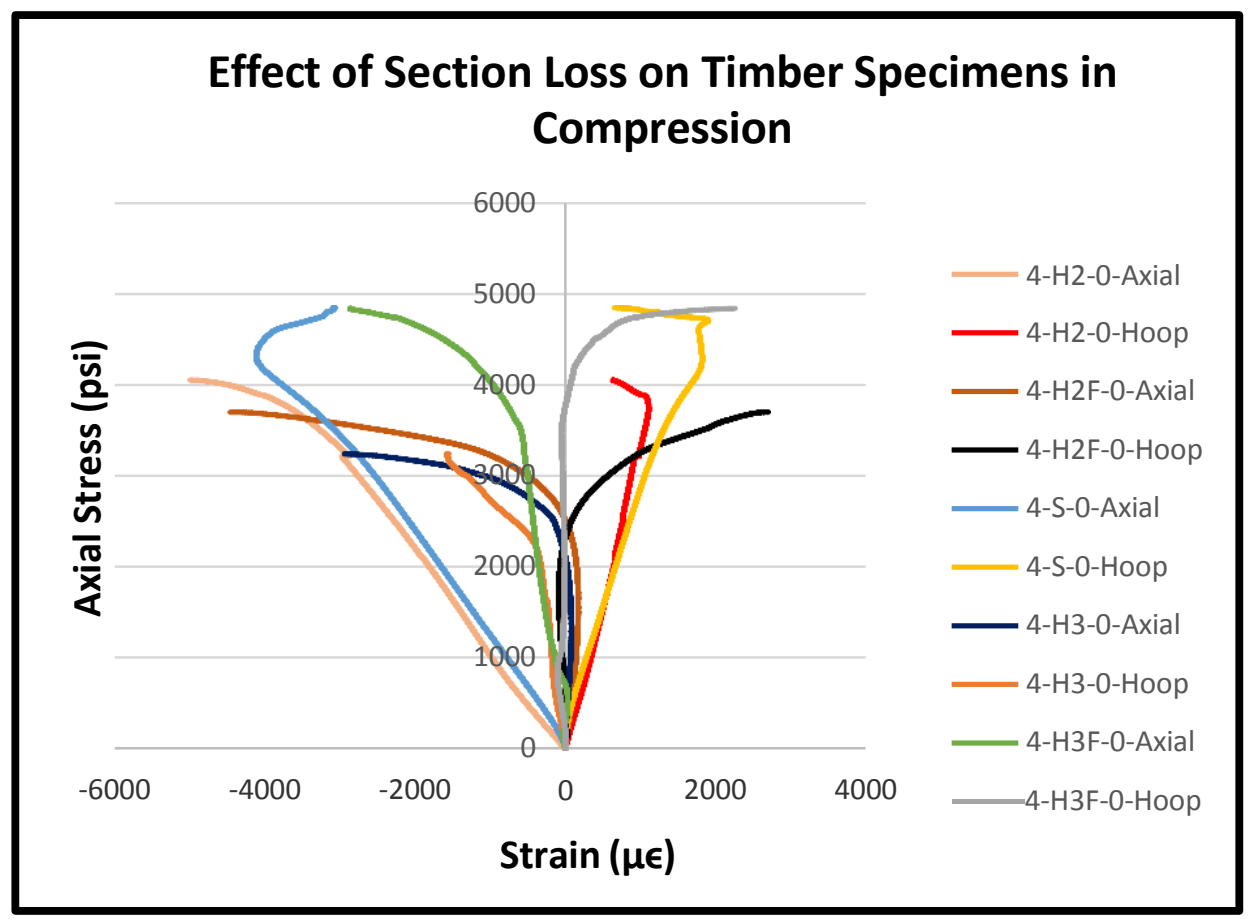

Figure 5.4: Variation of axial and hoop strains with axial compression load on timber cylinders 


\subsubsection{Effect of Wrap Layers on 2.0-inch Core-Filled Timber Specimens}

Timber specimens drilled and filled back with filler material are wrapped with 1,2 and 3 layers of Carbon fiber. Compressive behavior of timber cylinders with and without FRP is studied taking into consideration the contribution of filler material. These samples are tested and the results are tabulate in the Table 5.3

Table 5.3: Strength of hollow filled and wrapped 2.0" timber cylinders tested in axial compression

\begin{tabular}{|c|c|c|c|c|c|}
\hline Specimen & $\begin{array}{l}\text { Max. axial } \\
\text { strength, } \\
\text { (kip) }\end{array}$ & $\begin{array}{l}\text { Avg. axial } \\
\text { strength, } \\
\text { (kip) }\end{array}$ & $\begin{array}{c}\text { Avg. } \\
\text { increase in } \\
\text { strength per } \\
\text { layer (kip) }\end{array}$ & $\begin{array}{l}\text { Avg. axial } \\
\text { stress, } \\
\text { (psi) }\end{array}$ & $\begin{array}{l}\text { Avg. \% } \\
\text { Increase in } \\
\text { strength }\end{array}$ \\
\hline 4-H2F-0 & $\begin{array}{l}46.454 \\
57.859 \\
83.802\end{array}$ & 62.70 & - & 4989.905 & $\begin{array}{c}\text { Control } \\
\text { Specimen }\end{array}$ \\
\hline 4-H2F-C1 & $\begin{array}{l}99.358 \\
94.694 \\
96.551\end{array}$ & 96.87 & 34.16 & 7708.482 & 54.480 \\
\hline 4-H2F-C2 & $\begin{array}{c}94.651 \\
100.651 \\
89.280\end{array}$ & 94.86 & 16.08 & 7548.762 & 51.279 \\
\hline 4-H2F-C3 & $\begin{array}{c}109.841 \\
104.709 \\
109.65\end{array}$ & 108.06 & 15.12 & 8599.672 & 72.340 \\
\hline
\end{tabular}

Ratio of average increase in strength for 1,2 and 3 layers of wrapped cylinders to no wrap cylinders is determined to be $1.54,1.51$ and 1.72 respectively.

It is understood that one layer has better load carrying ability and confinement as compared to the two layer whereas the third layer has an increase of $32.8 \%$ in average strength over single layer and $72.340 \%$ increase over the unwrapped cylinders. 
The average percentage increase in strength per layer for 1, 2 and 3 layered specimens are $54.50 \%, 25.60 \%$ and $24.10 \%$ respectively.

Increase in number of wrap layers enhances axial strength and confinement, but here it is clear that with increase in number of layers, the response (i.e. \% increase) is not as significant as in for 1 layer.

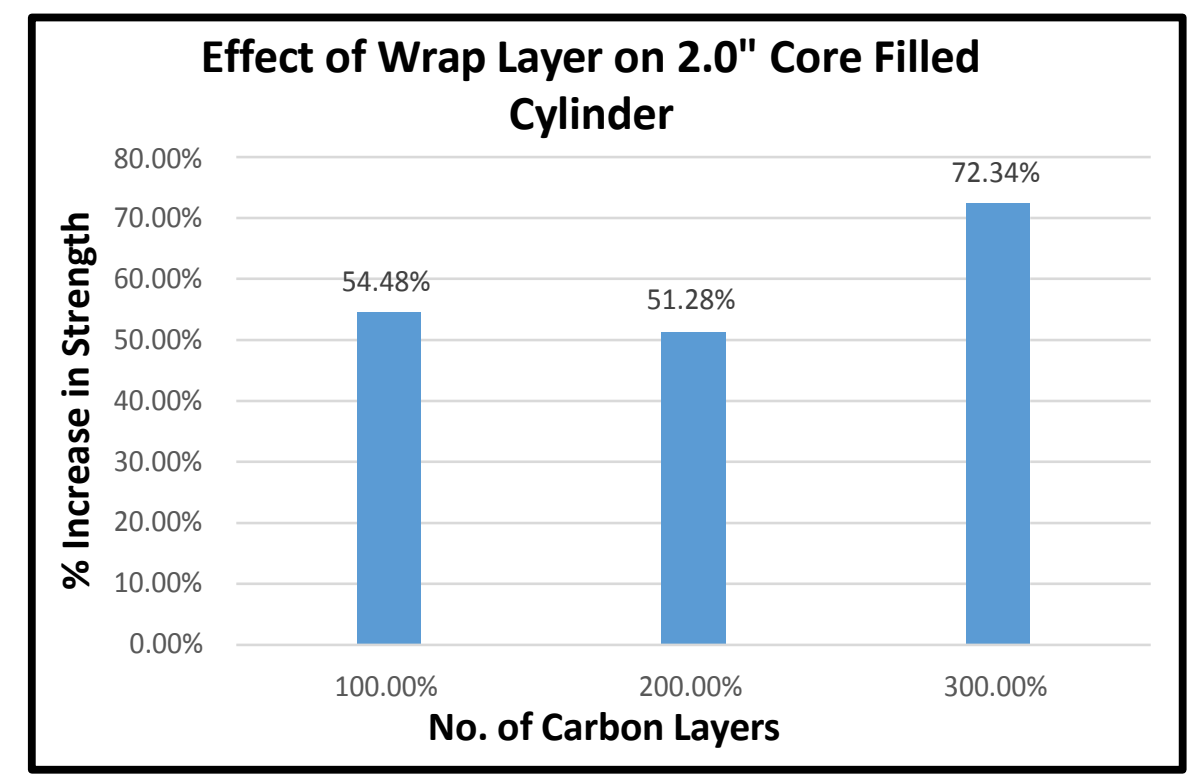

Figure 5.5: Average percentage increase in strength for CFRP wrapped core filled timber cylinders in axial compression 


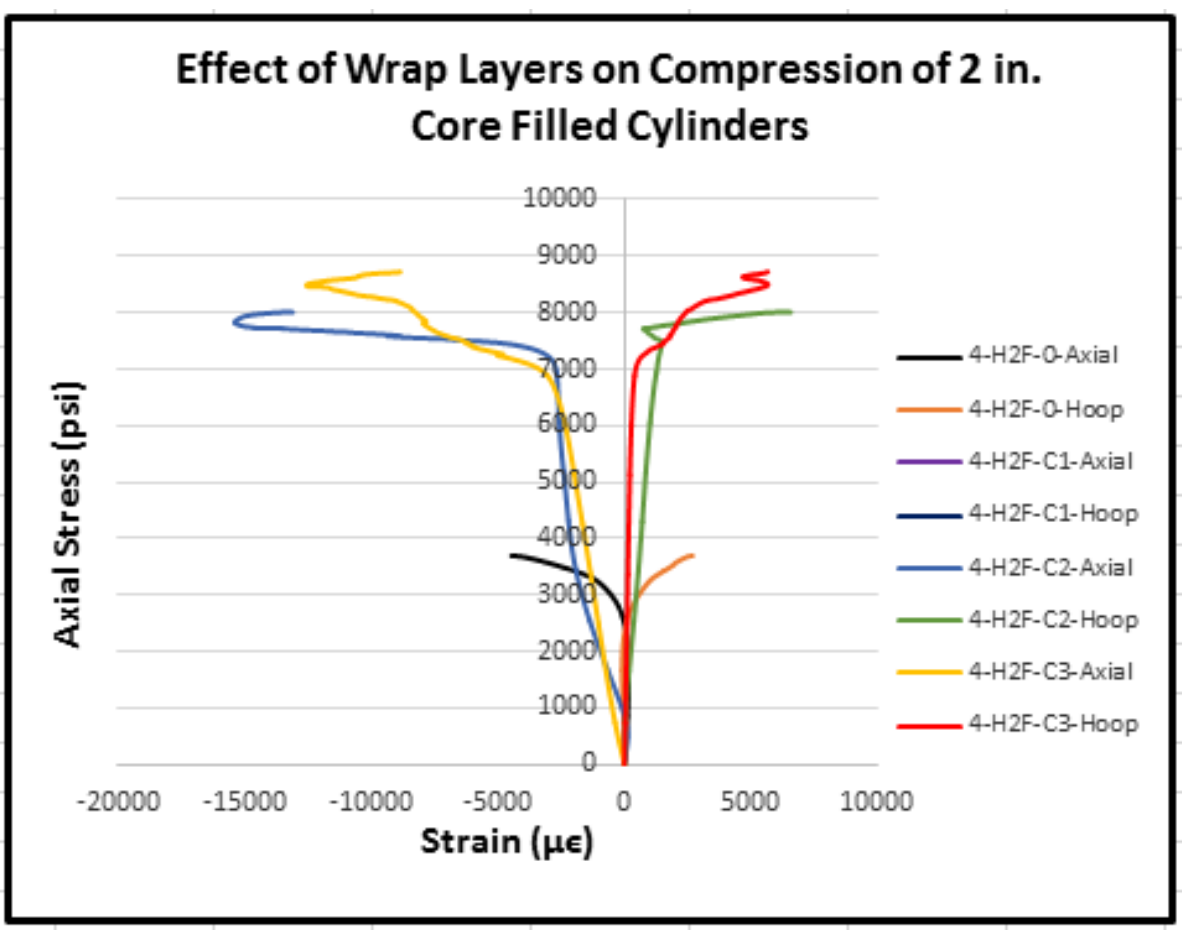

Figure 5.6: Variation in axial and hoop strains for 2.0" core filled cylinders with CFRP wrap

\subsubsection{Effect of Wrap Layers on Compression of 3.0-inch Core-Filled Cylinders}

3-inch core filled cylinders are wrapped with 1, 2 and 3 layers of CFRP and found that average increase in strength of 1,2 and 3 layered timber specimens w.r.t 3-inch core filled cylinder without FRP. Maximum axial compressive loads and stress are shown in the Table 5.4 below. 
Table 5.4: Strength of hollow filled and wrapped 3.0" timber cylinders tested in axial compression

\begin{tabular}{|c|c|c|c|c|c|}
\hline Specimen & $\begin{array}{l}\text { Max. axial } \\
\text { strength, } \\
\text { (Kip) }\end{array}$ & $\begin{array}{l}\text { Avg. axial } \\
\text { strength, } \\
\text { (Kip) }\end{array}$ & $\begin{array}{c}\text { Avg. } \\
\text { increase in } \\
\text { strength per } \\
\text { layer (Kip) }\end{array}$ & $\begin{array}{l}\text { Avg. axial } \\
\text { stress, } \\
\text { (Psi) }\end{array}$ & $\begin{array}{l}\text { Avg. \% Increase } \\
\text { in strength }\end{array}$ \\
\hline 4-H3F-0 & $\begin{array}{l}60.815 \\
73.933 \\
71.446\end{array}$ & 68.73 & - & 5469.46 & $\begin{array}{l}\text { Control } \\
\text { Specimen }\end{array}$ \\
\hline 4-H3F-C1 & $\begin{array}{l}123.296 \\
116.322 \\
119.414\end{array}$ & 119.41 & 50.68 & 9523.57 & 73.74 \\
\hline 4-H3F-C2 & $\begin{array}{l}106.161 \\
139.882 \\
100.768\end{array}$ & 115.60 & 23.44 & 9199.45 & 68.20 \\
\hline 4-H3F-C3 & $\begin{array}{c}106.22 \\
143.252 \\
61.588 *\end{array}$ & 124.73 & 18.67 & 8251.12 & 81.48 \\
\hline
\end{tabular}

$>$ The ratio of average increase in strengths are $1.74,1.68,1.81$ respectively for various cylindrical samples layered 1, 2 and 3.

$>$ Percentage increase in strength per layer for 1, 2 and 3 layers are determined to be $73.741 \%$, $34.10 \%$ and $27.16 \%$ respectively.

$>2.0$ " core filled cylinders with 2, 3-layer confinement have showed a decrease in average strength by $7.51 \%$ and an increase by $10.50 \%$ respectively in comparison with 1 layer cylinders. 


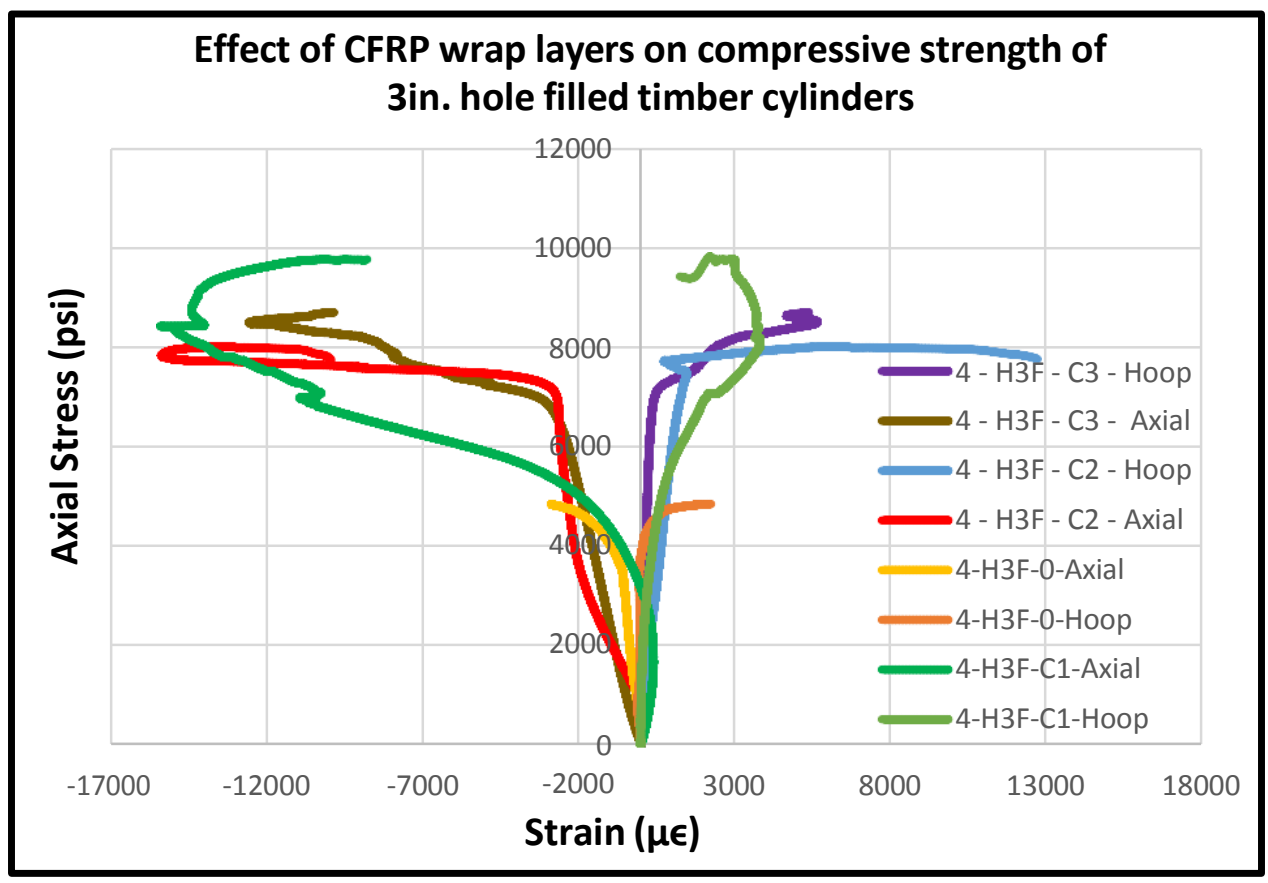

Figure 5.7: Stress Vs Strain plot for 3.0" core filled cylinders wrapped with CFRP

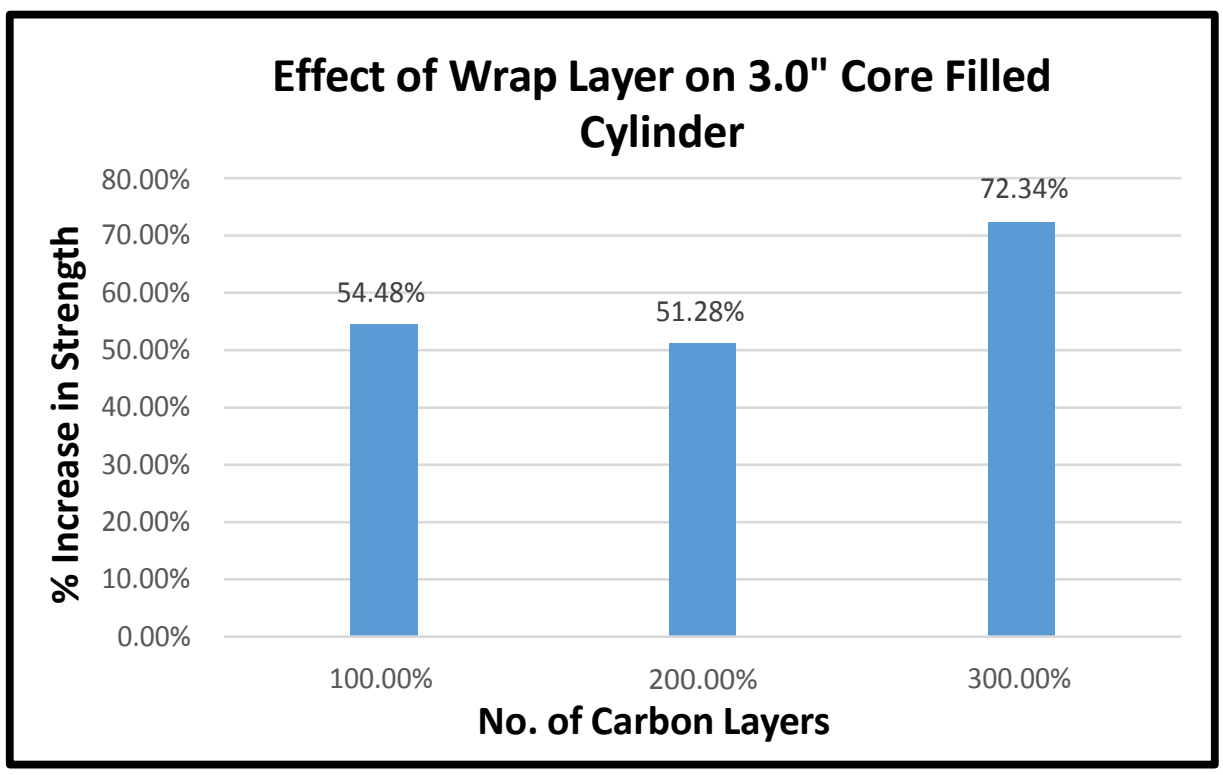

Figure 5.8: Average percentage increase in strength for CFRP wrapped 3.0" core filled timber cylinders in axial compression 


\subsubsection{Effect of FRP Wrapping on Solid and Core-filled Cylinders:}

Solid timber cylinders with 1 layer are compared with 2.0 inch and 3.0 inch filled hollow cylinders having 1-layer wrap. These specimens are wrapped with 1 layer of CFRP to determine the axial compressive strength along with the effect of confinement. The effect of wrap on various core filled timber samples is understood and the results for maximum strength and percentage increase are tabulated below in the Table 5.5.

Table 5.5: Comparison of axial strength of hollow filled cylinders with solid cylinder

\begin{tabular}{|c|c|c|c|c|}
\hline Specimen & $\begin{array}{l}\text { Max. axial } \\
\text { strength, } \\
\text { (Kip) }\end{array}$ & $\begin{array}{l}\text { Avg. axial } \\
\text { strength, } \\
\text { (Kip) }\end{array}$ & $\begin{array}{c}\text { Avg. axial } \\
\text { stress, } \\
\text { (Psi) }\end{array}$ & $\begin{array}{c}\text { Avg. \% } \\
\text { Increase in } \\
\text { strength }\end{array}$ \\
\hline 4-S-C1 & $\begin{array}{c}100.282 \\
77.75 \\
74.735\end{array}$ & 84.255 & 6706.202 & $\begin{array}{c}\text { Control } \\
\text { Specimen }\end{array}$ \\
\hline 4-H2F-C1 & $\begin{array}{l}99.358 \\
94.694 \\
96.551 \\
\end{array}$ & 96.867 & 7708.482 & 14.968 \\
\hline 4-H3F-C1 & $\begin{array}{l}123.296 \\
116.322 \\
119.414\end{array}$ & 119.414 & 9523.572 & 41.729 \\
\hline
\end{tabular}

Single wrap cylinders with 2 inch and 3-inch fill are tested which exhibits an increase in ultimate compression capacity by $14.97 \%$ and $41.73 \%$ respectively in reference to solid specimen with single wrap. 


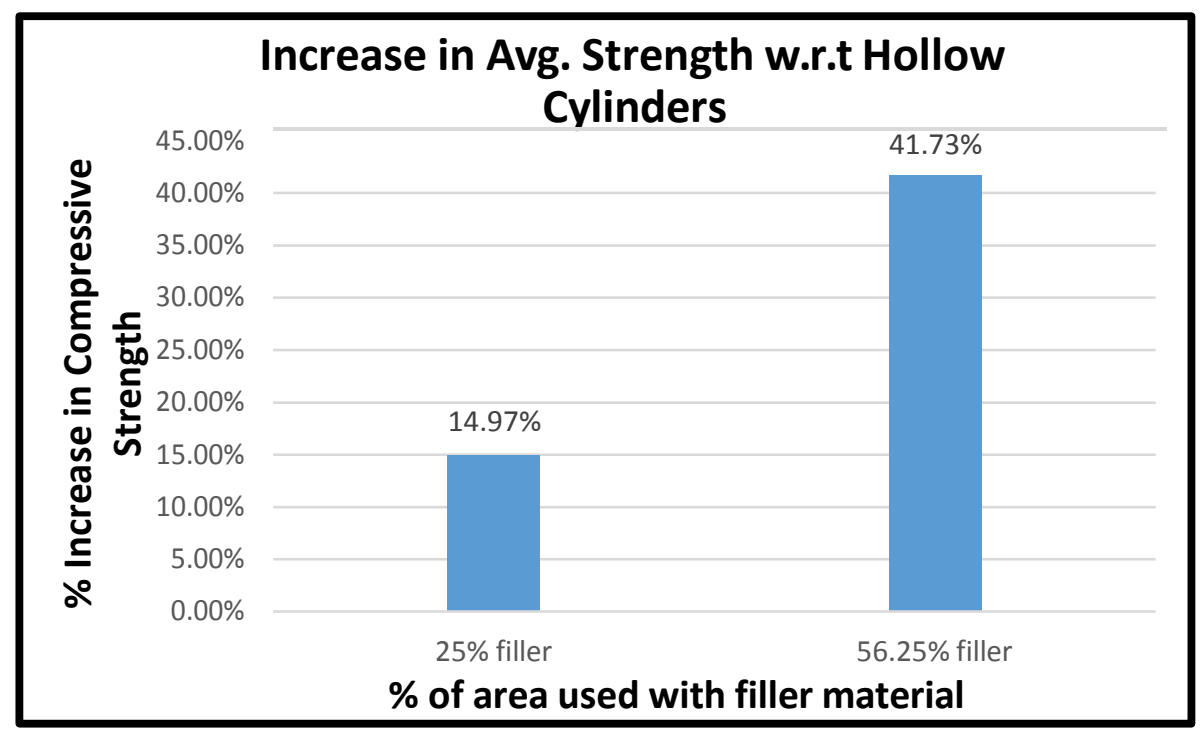

Figure 5.9: Average percentage increase in strength for CFRP wrapped 2.0" and 3.0" core filled timber cylinders

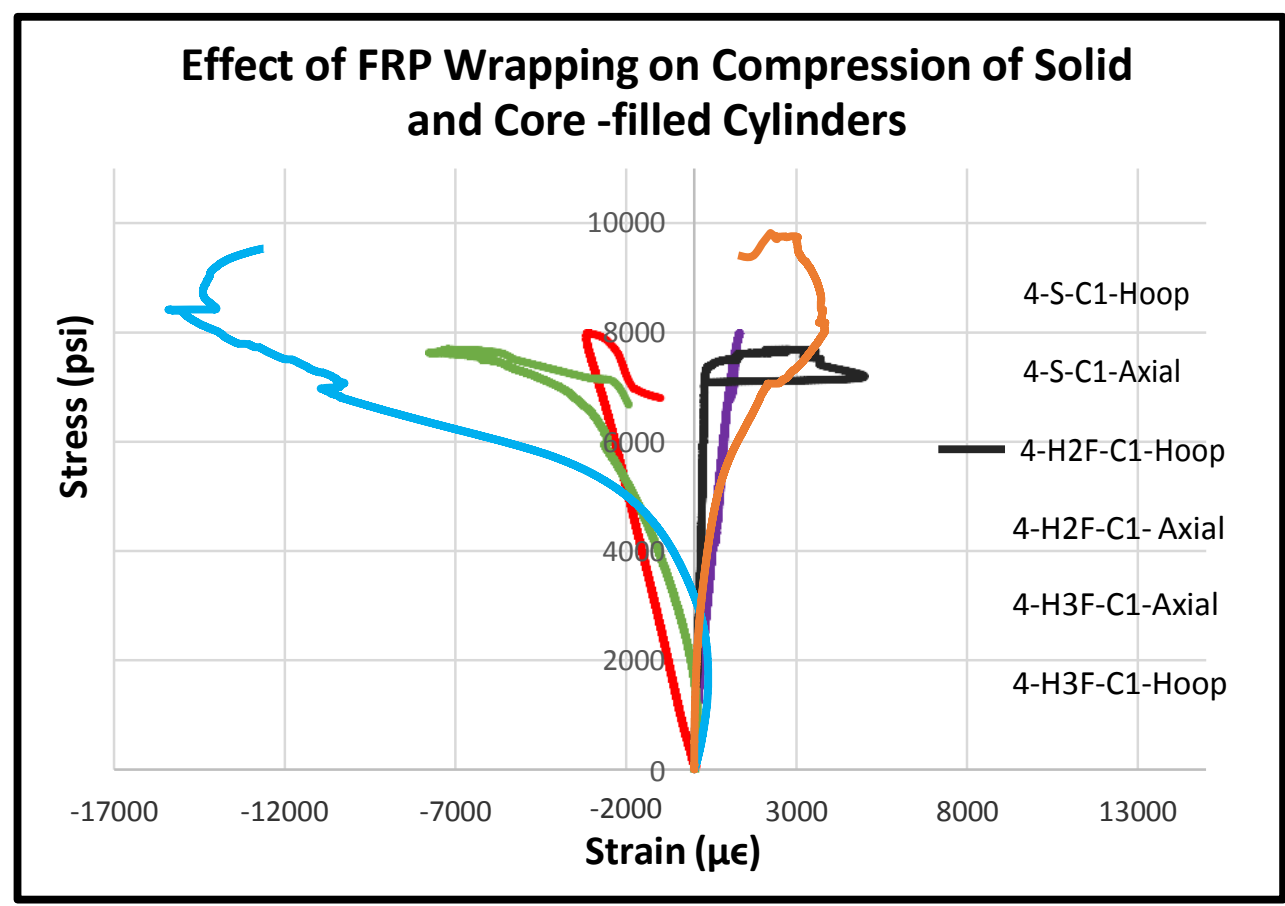

Figure 5.10: Comparison of axial strain to hoop strain for 2.0" and 3.0" core filled cylinders with wrap 


\subsection{Failure Modes}

Figure 5.12 and 5.13 show failure modes of timber cylinder specimens with and without carbon FRP tested in axial compression

\subsubsection{Non Wrapped Timber Cylinders}

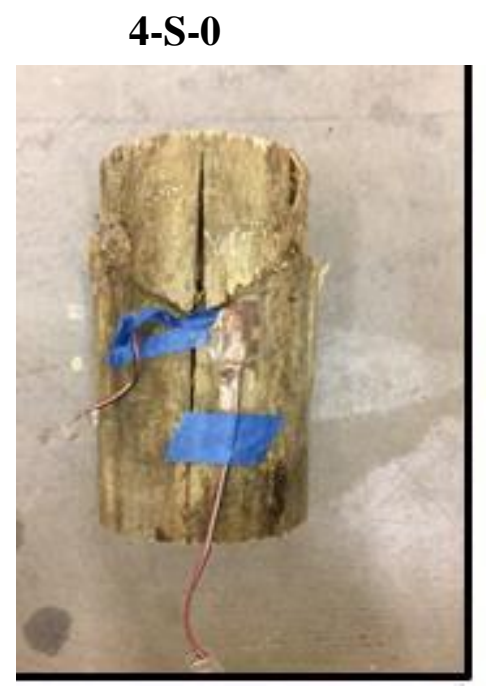

4-H2F-0

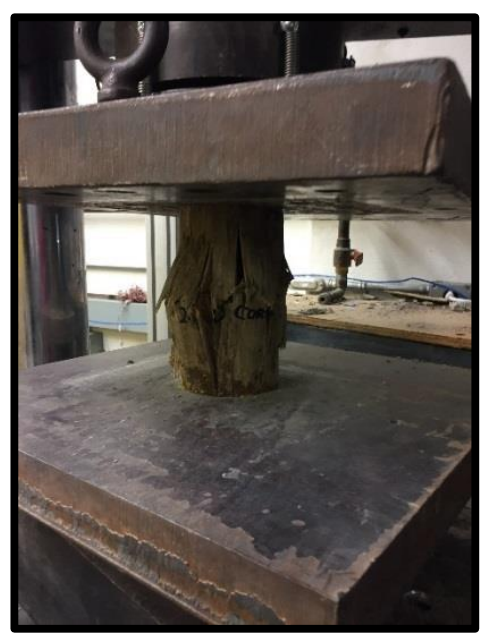

4-H2-0

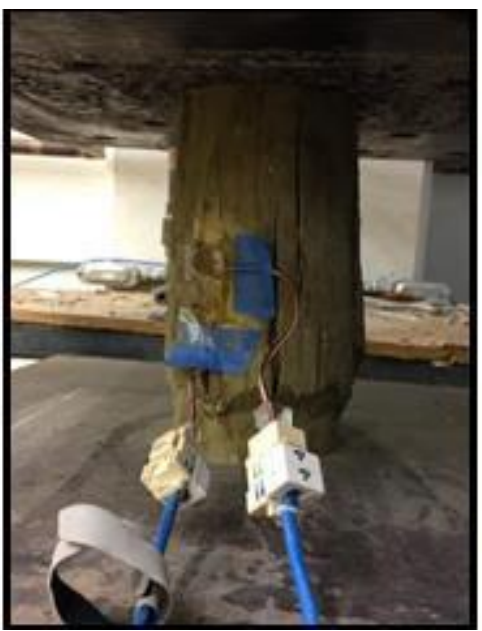

.

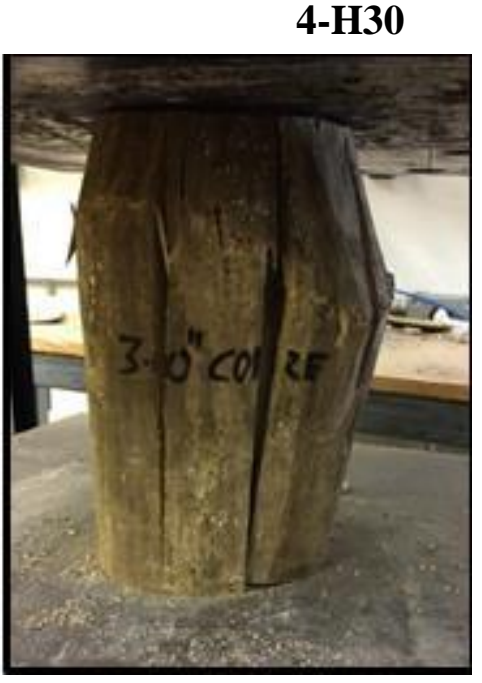

4-H3F-0

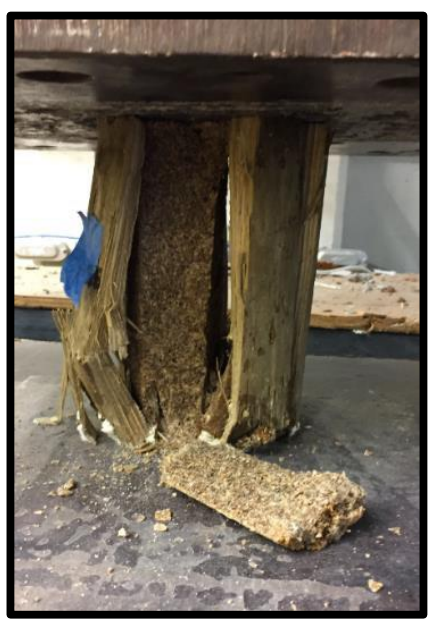

Figure 5.11: Timber cylinders without CFRP wrap and various configurations 


\subsubsection{Wrapped Timber Cylinders}

Cylinders wrapped with 1, 2 and 3 layers of unidirectional carbon are tested in axial compression and failure modes are understood
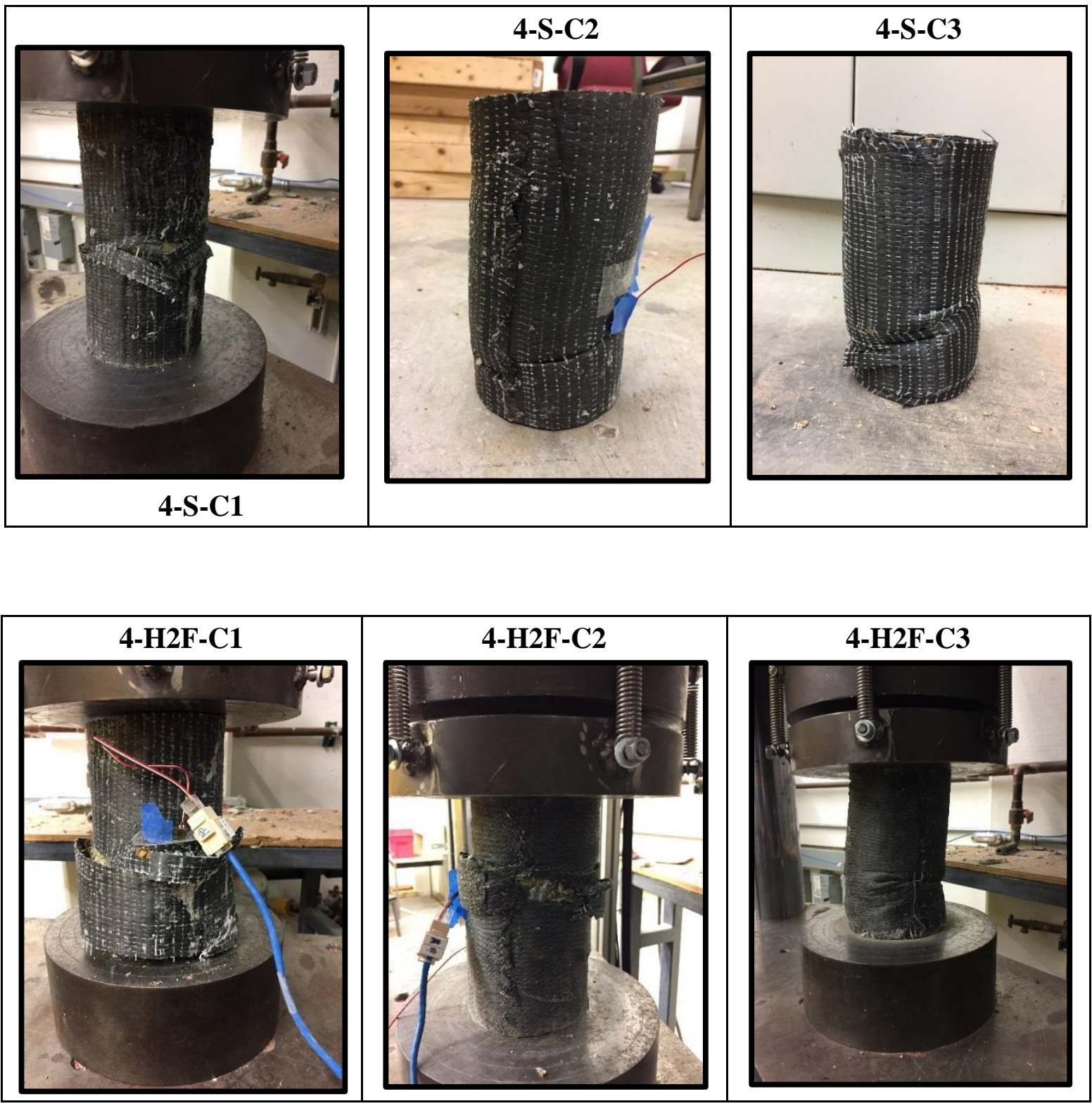
4-H3F-C1

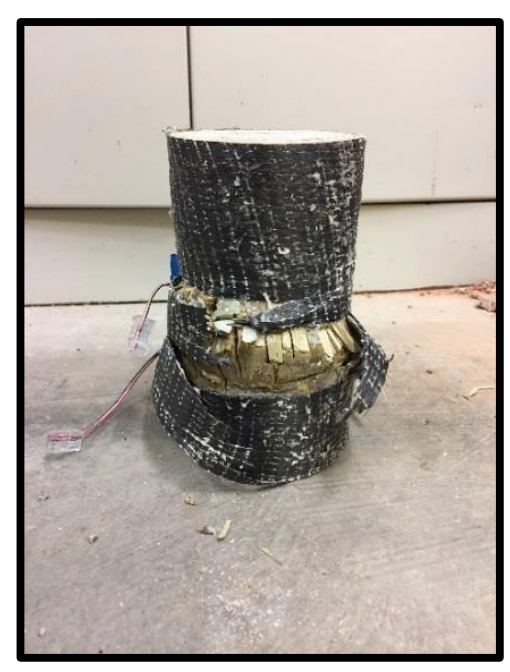

4-H3F-C

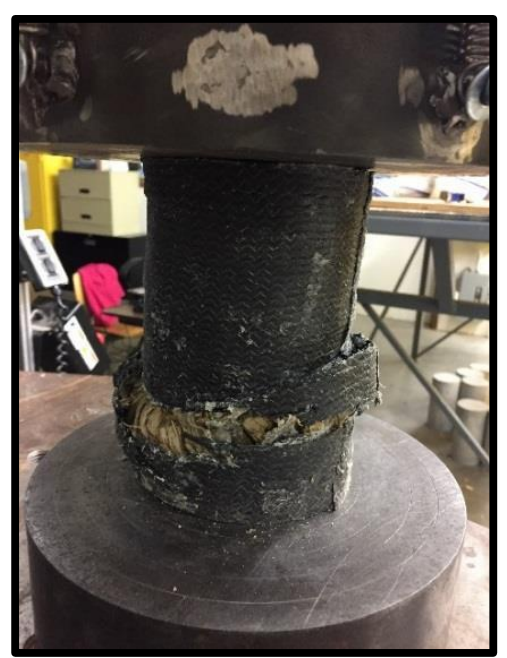

4-H3F-C3

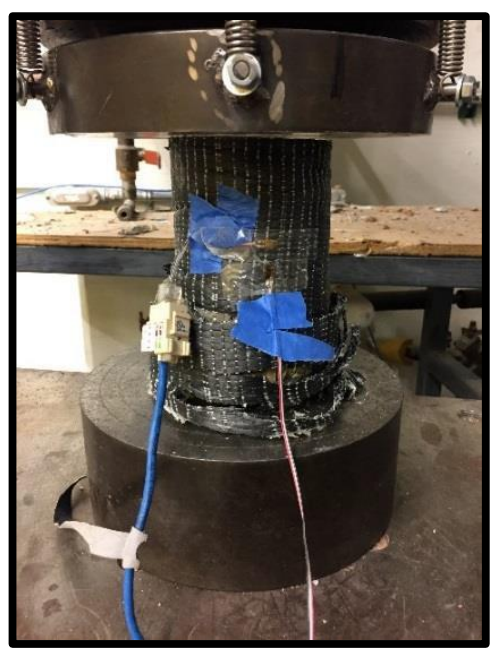

Figure 5.12: Timber cylinders with CFRP wrap and various configurations

Solid specimens with no wrap failed in crushing and shear dominated failure, whereas the hollow core sections failed due to buckling of woof fibers.

Solid Specimens with filled core failed due to outer fiber buckling and inner core crushing and splitting.

$>$ Solid timber cylinder wrapped with unidirectional carbon fabric failed due to crushing of wood and rupture in fabric.

$>2.0$ " core filled cylinders wrapped with 1 layer CFRP failed with buckling of wood fibers followed by failure in the wrap at the mid height at the position of maximum hoop strain, whereas the 3-layer cylinder failed due to crushing of wood.

3.0" core filled, wrapped cylinders failed in buckling of wood followed by rupture of fabric all around the circumference. 


\subsection{Glass wrap/ aqua wrap on cylinders}

Glass FRP is used to wrap 1, 2 and 3 layers on 8-inch-long timber specimens. GFRP aqua wrap is water activated pre-impregnated wrap and doesn't need any primer. Stricter banding is wrapped on the glass FRP to eliminate vacuum and also to make sure that all the layers are bonded together.

\subsubsection{Effect of GFRP Wrap Layers on Compressive Strength of Solid Timber Specimens}

Solid timber specimens with Glass fiber polymers are tested to understand the behavior of timber in axial compression and the strength enhancement by FRP in hoop direction. . The maximum axial load capacity and average stress for solid cylinders with and without wrap are reported in the Table 5.1 below.

Table 5.6: Strength of wrapped and non-wrapped GFRP timber specimens in axial compression

\begin{tabular}{|c|c|c|c|c|c|}
\hline Specimen & $\begin{array}{c}\text { Max. } \\
\text { axial } \\
\text { strength, } \\
\text { (kip) }\end{array}$ & $\begin{array}{c}\text { Avg. } \\
\text { axial } \\
\text { strength, } \\
\text { (kip) }\end{array}$ & $\begin{array}{c}\text { Avg. } \\
\text { increase in } \\
\text { strength per } \\
\text { layer } \\
\text { (kip) }\end{array}$ & $\begin{array}{l}\text { Avg. } \\
\text { axial } \\
\text { stress, } \\
\text { (psi) }\end{array}$ & $\begin{array}{c}\text { Avg. \% } \\
\text { increase } \\
\text { in } \\
\text { strength }\end{array}$ \\
\hline $4-S-0$ & $\begin{array}{l}60.9 \\
72.7 \\
66.4\end{array}$ & 66.7 & - & 5055.9 & $\begin{array}{c}\text { Control } \\
\text { Specimen }\end{array}$ \\
\hline $4-\mathrm{S}-\mathrm{G} 2$ & $\begin{array}{c}68.3 \\
102.9 * \\
83.0\end{array}$ & 84.76 & 9.03 & 6744.9 & 13.43 \\
\hline $4-\mathrm{S}-\mathrm{G} 3$ & $\begin{array}{l}73.10 \\
69.41 \\
83.15\end{array}$ & 75.22 & 2.85 & 5986.05 & 12.77 \\
\hline
\end{tabular}

Solid timber cylinders wrapped with 2 and 3 layer of glass fiber showed an average percentage increase in strength of $13.43 \%$ and $12.77 \%$ with respect to control specimen.

$>$ The average percentage increase in strength per layer for 2 and 3 layered specimens is $13.5 \%$, and $4.27 \%$ respectively w.r.t control specimen. 


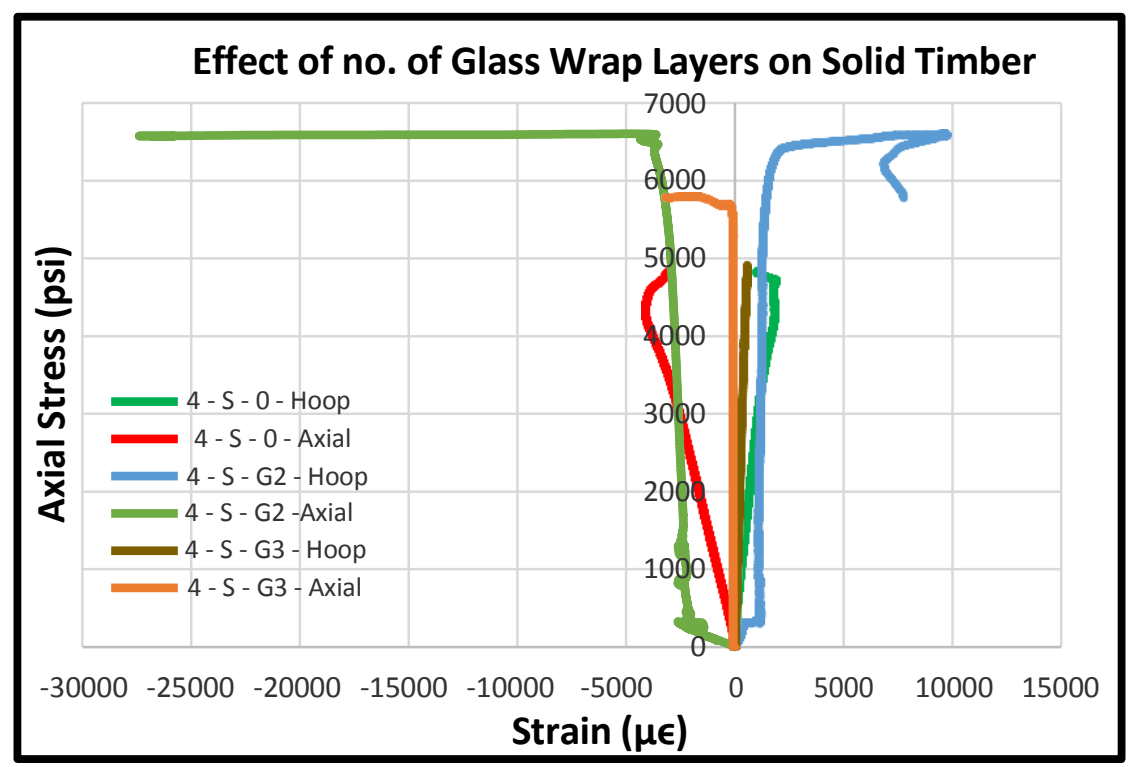

Figure 5.13: Comparison on effect of number of GFRP layers on timber cylinders

\subsubsection{Effect of GFRP Wrap Layers on 2.0" Hollow and Core Filled Timber Specimens}

2.1" hollow timber specimen with 2 layer GFRP is tested in comparison with 2.0" hollow filled cylinder to understand the behavior of hollow and filled core specimens considering confinement effects.

Table 5.7: Strength of wrapped and non-wrapped GFRP timber specimens in axial compression

\begin{tabular}{|c|c|c|c|c|}
\hline Specimen & $\begin{array}{c}\text { Max. } \\
\text { axial } \\
\text { strength, } \\
\text { (Kip) }\end{array}$ & $\begin{array}{c}\text { Avg. } \\
\text { axial } \\
\text { strength, } \\
\text { (Kip) }\end{array}$ & $\begin{array}{l}\text { Avg. } \\
\text { axial } \\
\text { stress, } \\
\text { (Psi) }\end{array}$ & $\begin{array}{l}\text { Avg. \% } \\
\text { change in } \\
\text { strength }\end{array}$ \\
\hline $4-S-0$ & $\begin{array}{l}60.9 \\
72.7 \\
66.4\end{array}$ & 66.7 & 5055.9 & $\begin{array}{c}\text { Control } \\
\text { Specimen }\end{array}$ \\
\hline $4-\mathrm{H} 2-\mathrm{G} 2$ & $\begin{array}{c}67.906 \\
59.63 \\
58.165\end{array}$ & 62.229 & 4925.872 & -7.22 \\
\hline $\begin{array}{c}4-\mathrm{H} 2 \mathrm{~F}- \\
\mathrm{G} 2\end{array}$ & $\begin{array}{l}73.593 \\
76.331 \\
73.166\end{array}$ & 74.36 & 5917.646 & 11.45 \\
\hline
\end{tabular}


2.0" hollow timber specimen and 2.0" core filled cylinder wrapped with 2 layer of glass fabric showed an average percentage decrease in strength of $7.22 \%$ and increase of $11.45 \%$ respectively, with respect to control specimen.

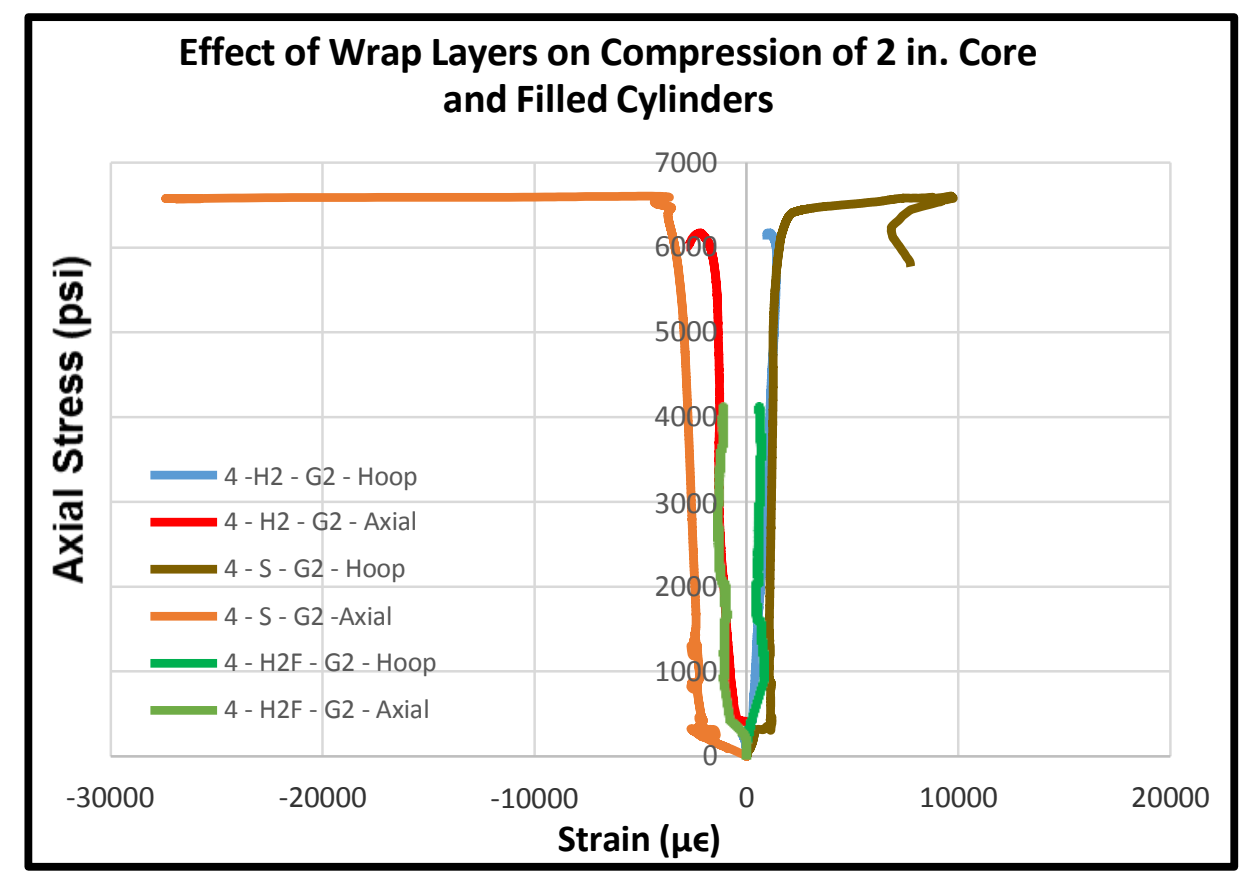

Figure 5.14: Stress Vs Strain plot on effect of GFRP wrap on 2.0" core and filled timber cylinders

\subsubsection{Effect of GFRP Wrap Layers on Compressive Strength of 2.0" Hollow Timber Specimens}

2 inch hollow timber specimens wrapped with 2 and 3 layer of Glass fiber polymers are tested to understand the behavior of timber in axial compression and strength enhancement by FRP in hoop direction. The maximum axial load capacity and average stress for hollow cylinders with and without wrap are reported in the Table 5.1 below. 
Table 5.1: Strength of wrapped and non-wrapped GFRP timber specimens in axial compression

\begin{tabular}{|c|c|c|c|c|c|}
\hline Specimen & $\begin{array}{l}\text { Max. } \\
\text { axial } \\
\text { strength, } \\
\text { (kip) }\end{array}$ & $\begin{array}{l}\text { Avg. } \\
\text { axial } \\
\text { strength, } \\
\text { (kip) }\end{array}$ & $\begin{array}{l}\text { Avg. } \\
\text { increase in } \\
\text { strength per } \\
\text { layer (kip) }\end{array}$ & $\begin{array}{l}\text { Avg. } \\
\text { axial } \\
\text { stress, } \\
\text { (psi) }\end{array}$ & $\begin{array}{l}\text { Avg. \% } \\
\text { increase } \\
\text { strength }\end{array}$ \\
\hline $4-\mathrm{H} 2-0$ & $\begin{array}{l}50.912 \\
65.617 \\
58.533\end{array}$ & 58.35 & - & 6191.55 & $\begin{array}{c}\text { Control } \\
\text { Specimen }\end{array}$ \\
\hline $4-\mathrm{H} 2-\mathrm{G} 2$ & $\begin{array}{c}67.906 \\
59.63 \\
58.165\end{array}$ & 61.90 & 1.77 & 4925.87 & 6.07 \\
\hline $4-\mathrm{H} 2-\mathrm{G} 3$ & $\begin{array}{l}68.733 \\
66.278 \\
51.677\end{array}$ & 62.22 & 1.29 & 6602.74 & 6.62 \\
\hline
\end{tabular}

Ratio of average increase in strength for 2 and 3 layers of wrapped cylinders to no wrap cylinders is determined to be 1.06 and 1.066 respectively.

The average percentage increase in strength per layer for 2 and 3 layered specimens is $6.07 \%, 6.62 \%$ respectively.

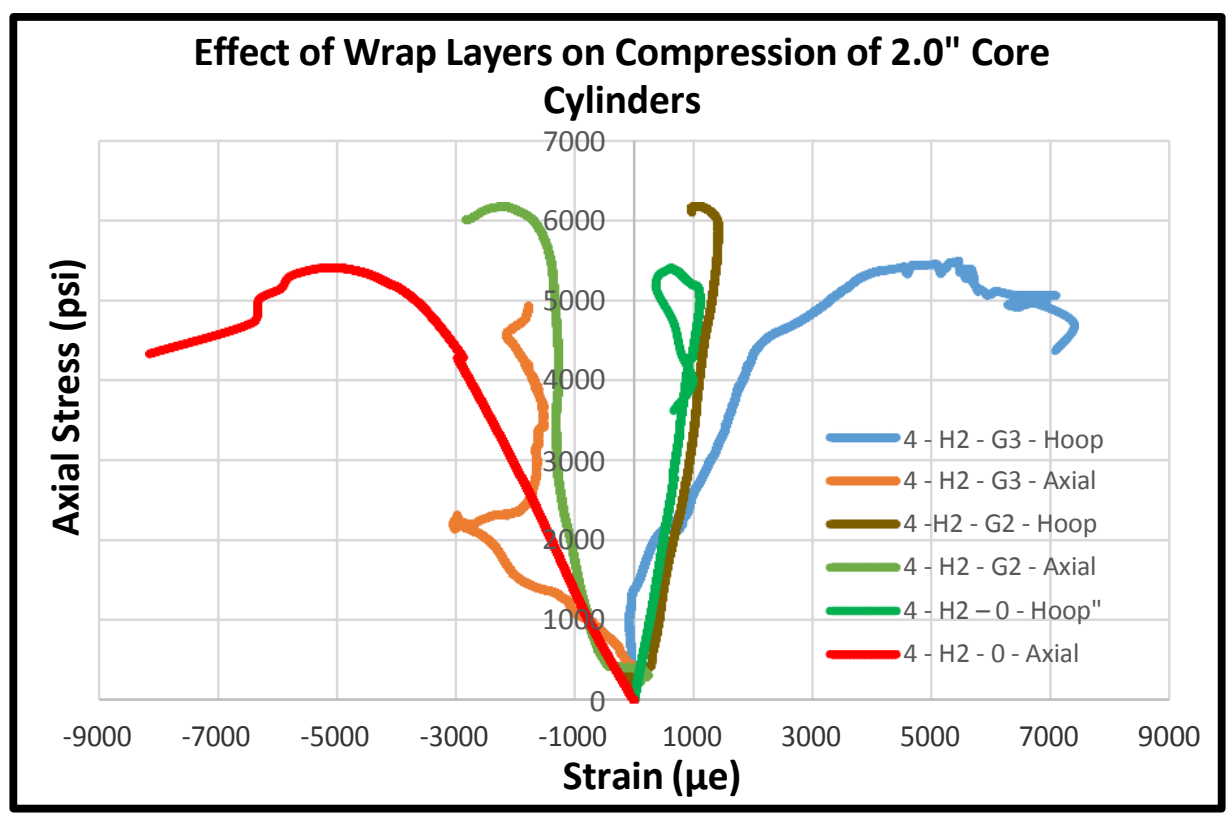

Figure 5.15: Comparison on effect of GFRP layers on axial compression of 2.0" hollow timber cylinders 


\subsubsection{Effect of GFRP Wrap Layers on Compressive Strength of Solid, 2.0" Filled Timber Specimens}

Timber specimens filled with filler material are wrapped with 1, 2 and 3 layers of Glass fiber. Compressive behavior of timber cylinders with and without FRP is studied taking into consideration the contribution of filler material. These samples are tested and the results are tabulate in the Table

Figure 5.9: Strength of hollow filled and wrapped 2.0" timber cylinders tested in axial compression

\begin{tabular}{|c|c|c|c|c|c|}
\hline Specimen & $\begin{array}{c}\text { Max. } \\
\text { axial } \\
\text { strength, } \\
\text { (kip) }\end{array}$ & $\begin{array}{c}\text { Avg. } \\
\text { axial } \\
\text { strength, } \\
\text { (kip) }\end{array}$ & $\begin{array}{c}\text { Avg. } \\
\text { increase in } \\
\text { strength per } \\
\text { layer } \\
\text { (kip) }\end{array}$ & $\begin{array}{l}\text { Avg. } \\
\text { axial } \\
\text { stress, } \\
\text { (psi) }\end{array}$ & $\begin{array}{l}\text { Avg. \% } \\
\text { change in } \\
\text { strength }\end{array}$ \\
\hline \multirow{3}{*}{$4-\mathrm{H} 2 \mathrm{~F}-0$} & 46.45 & \multirow{3}{*}{62.7} & \multirow{3}{*}{ - } & \multirow{3}{*}{4989.9} & \multirow{3}{*}{$\begin{array}{c}\text { Control } \\
\text { Specimen }\end{array}$} \\
\hline & 57.86 & & & & \\
\hline & 83.8 & & & & \\
\hline \multirow{3}{*}{$\begin{array}{c}4-\mathrm{H} 2 \mathrm{~F}- \\
\mathrm{G} 1\end{array}$} & 80.387 & \multirow{3}{*}{82.80} & \multirow{3}{*}{20.1} & \multirow{3}{*}{4925.872} & \multirow{3}{*}{32.04} \\
\hline & 85.216 & & & & \\
\hline & - & & & & \\
\hline \multirow{3}{*}{$\begin{array}{c}4-\mathrm{H} 2 \mathrm{~F}- \\
\mathrm{G} 2\end{array}$} & 73.593 & \multirow{3}{*}{74.36} & \multirow{3}{*}{5.83} & \multirow{3}{*}{5917.646} & \multirow{3}{*}{18.58} \\
\hline & 76.331 & & & & \\
\hline & 73.166 & & & & \\
\hline \multirow{3}{*}{$\begin{array}{c}4-\mathrm{H} 2 \mathrm{~F}- \\
\mathrm{G} 3\end{array}$} & 71.136 & \multirow{3}{*}{79.098} & \multirow{3}{*}{5.5} & \multirow{3}{*}{6294.472} & \multirow{3}{*}{26.15} \\
\hline & 90.319 & & & & \\
\hline & 75.841 & & & & \\
\hline
\end{tabular}

$>$ Ratio of average increase in strength for 1,2 and 3 layers of wrapped cylinders to no wrap cylinders is determined to be $1.32,1.18$ and 1.26 respectively.

It is understood that one layer has better load carrying ability and confinement as compared to the two layer. 
$>$ The average percentage increase in strength per layer for 1, 2 and 3 layered specimens are $32.04 \%, 18.58 \%$ and $26.15 \%$ respectively.

Increase in number of wrap layers enhances axial strength and confinement, but here it is clear that with increase in number of layers, the response (i.e. \% increase) is not as significant as in for 1 layer.

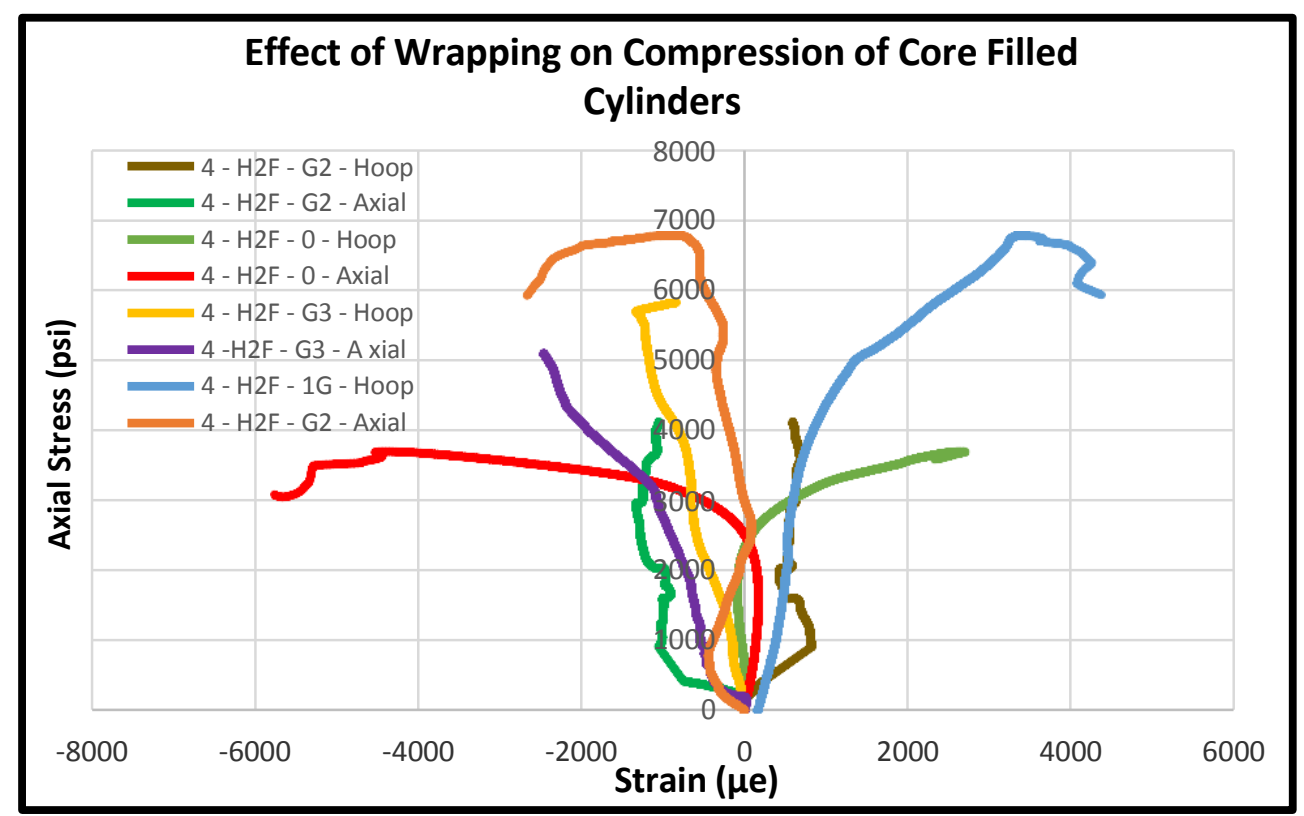

Figure 5.16: Stress Vs Strain plot for 2.0" core filled cylinders wrapped with GFRP

\subsection{Failure Mode}

Figure shows the failure modes in timber cylinders wrapped with GFRP and tested in axial compression. 


\subsubsection{Wrapped Timber Cylinders}
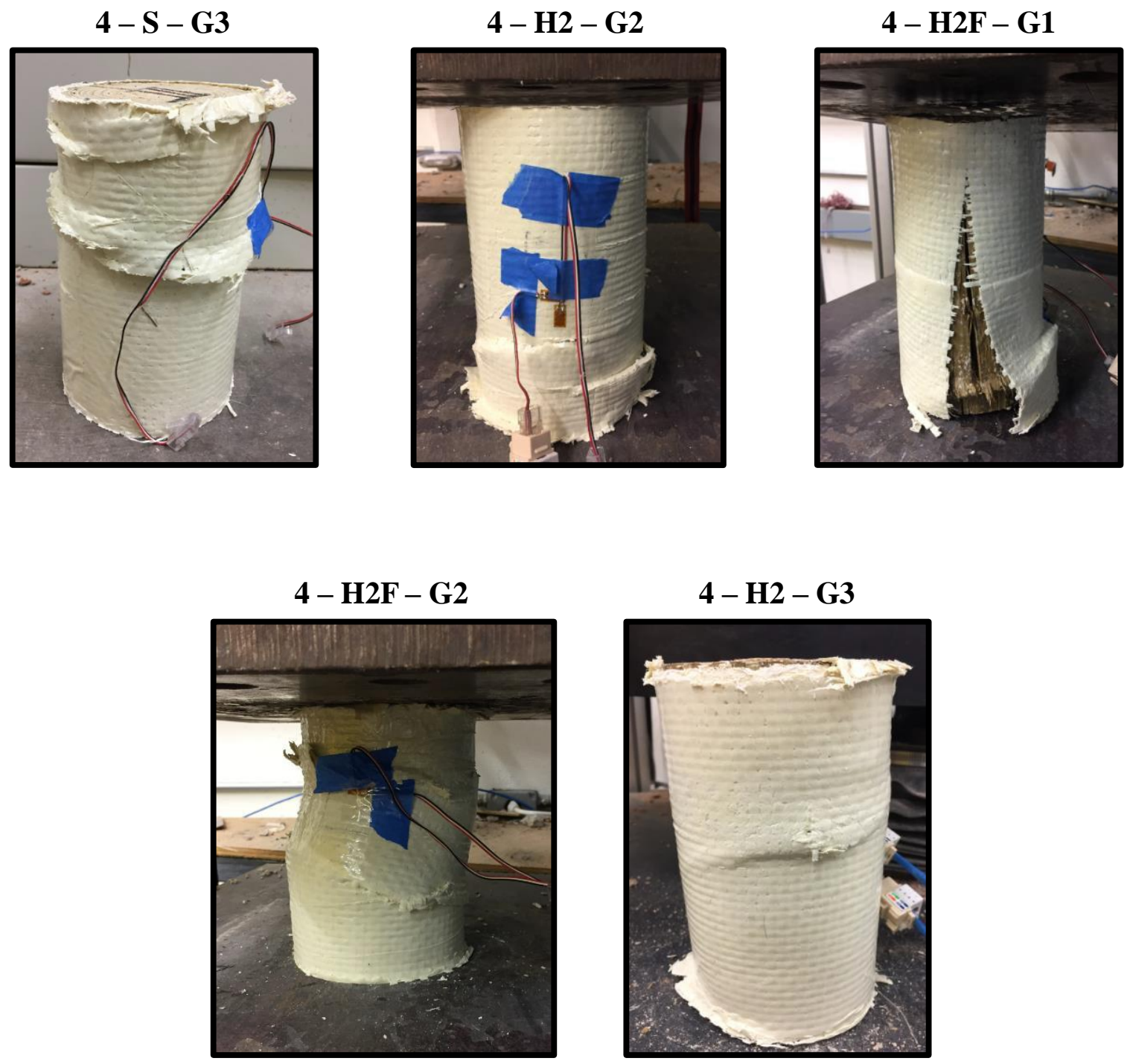

Figure 7.17: Failure modes in timber cylinders with GFRP wrap and various configurations

$>$ Solid timber cylinder wrapped with GFRP fabric failed due to crushing of wood with shear domination (shear angle present).

Hollow core cylinders failed with buckling of fibers followed by rupture of FRP.

Solid Specimens with filled core failed due to outer fiber buckling and inner core crushing and splitting. 


\subsection{Comparison of CFRP Vs GFRP}

CFRP and GFRP fabric is used in confining timber cylinders and also enhance their strength.

\subsubsection{Effect of CFRP \& GFRP Wrap (2 layers) on Compressive Strength of Solid Timber Cylinders}

The effect of CFRP and GFRP on confinement of solid timber cylinders with 2 layer carbon and glass

Table 5.10: Strength of solid timber cylinder with 2 layer of CFRP and GFRP wrap

\begin{tabular}{|c|c|c|c|c|}
\hline Specimen & $\begin{array}{l}\text { Max axial } \\
\text { strength, } \\
\text { (kip) }\end{array}$ & $\begin{array}{l}\text { Avg. axial } \\
\text { strength, } \\
\text { (kip) }\end{array}$ & $\begin{array}{l}\text { Avg. } \\
\text { axial } \\
\text { stress } \\
\text { (psi) }\end{array}$ & $\begin{array}{l}\text { Avg. } \% \\
\text { change in } \\
\text { strength }\end{array}$ \\
\hline $4-\mathrm{S}-0$ & $\begin{array}{l}60.9 \\
72.7 \\
66.4\end{array}$ & 66.7 & 5055.9 & $\begin{array}{c}\text { Control } \\
\text { Specimen }\end{array}$ \\
\hline $4-S-C 2$ & $\begin{array}{c}88.3 \\
75.75 \\
88.84\end{array}$ & 84.41 & 6716.92 & 26.55 \\
\hline $4-\mathrm{S}-\mathrm{G} 2$ & $\begin{array}{l}73.10 \\
69.41 \\
83.15\end{array}$ & 84.76 & 6744.96 & 27.07 \\
\hline
\end{tabular}

Solid timber cylinders with 2 layers of CFRP and GFRP has an increase of $26 \%$ and $27 \%$ with respect to solid timber cylinder with no wrap. 


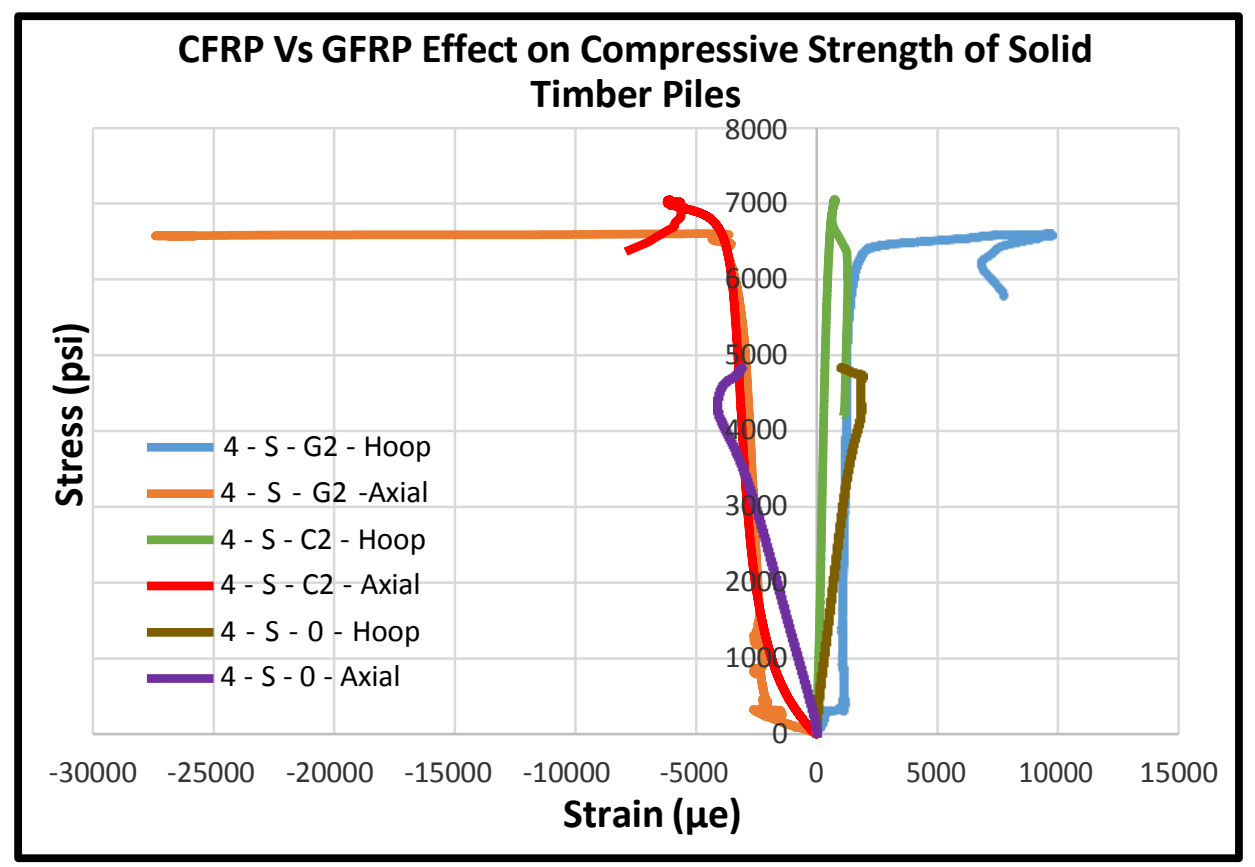

Figure 5.18: Stress Vs Strain plot for solid timber cylinders with 2 layers of CFRP and GFRP wrap

\subsubsection{Effect of CFRP \& GFRP Wrap (2 layers) on 2.0" Core Filled Timber Cylinders}

Table 5.11: Strength of 2.0" core filled timber cylinder with 2 layer of CFRP and GFRP wrap

\begin{tabular}{|c|c|c|c|c|}
\hline Specimen & $\begin{array}{l}\text { Max axial } \\
\text { strength, } \\
\text { (kip) }\end{array}$ & $\begin{array}{l}\text { Avg. axial } \\
\text { strength, } \\
\text { (kip) }\end{array}$ & $\begin{array}{l}\text { Avg. } \\
\text { axial } \\
\text { stress } \\
\text { (psi) }\end{array}$ & $\begin{array}{c}\text { Avg. } \% \\
\text { change in } \\
\text { strength }\end{array}$ \\
\hline $4-\mathrm{H} 2 \mathrm{~F}-0$ & $\begin{array}{l}46.45 \\
57.86 \\
83.80\end{array}$ & 62.70 & 4989.90 & $\begin{array}{c}\text { Control } \\
\text { Specimen }\end{array}$ \\
\hline $4-\mathrm{H} 2 \mathrm{~F}-\mathrm{C} 2$ & $\begin{array}{c}94.65 \\
100.65 \\
89.28\end{array}$ & 94.86 & 7548.76 & 51.29 \\
\hline $4-\mathrm{H} 2 \mathrm{~F}-\mathrm{G} 2$ & $\begin{array}{l}73.59 \\
76.33 \\
73.17\end{array}$ & 74.36 & 5917.65 & 18.60 \\
\hline
\end{tabular}

2.0" core filled timber cylinders with 2 layers of CFRP and GFRP has an increase of $51.3 \%$ and $18.6 \%$ with respect to 2.0 " core filled timber cylinder without wrap. 


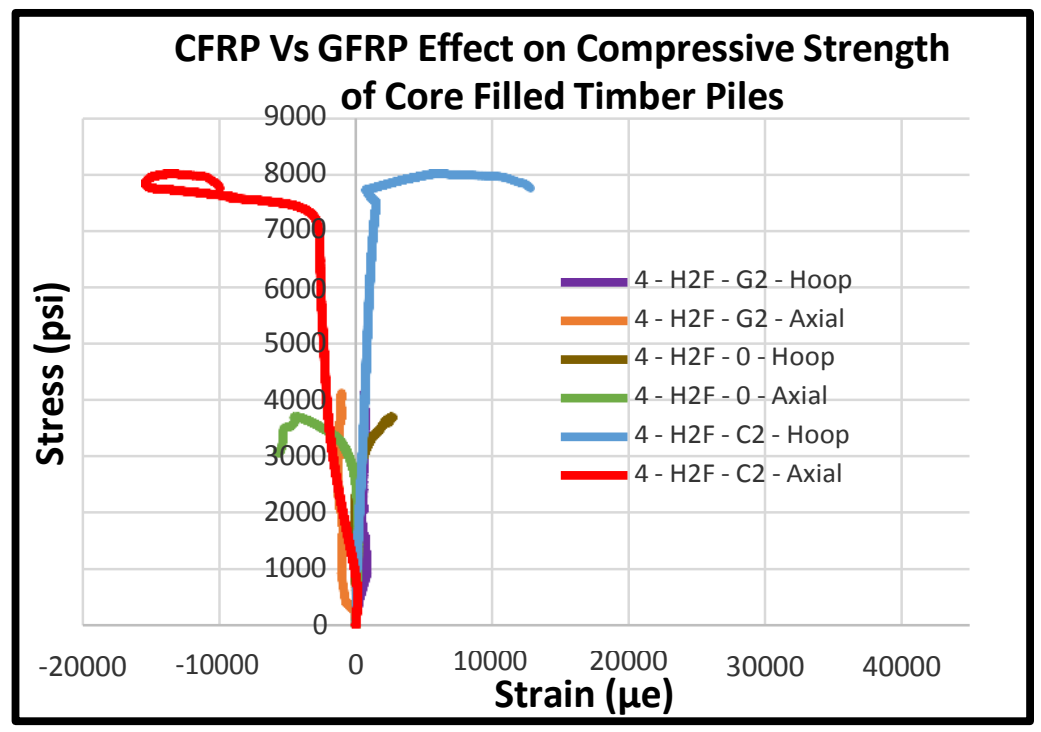

Figure 5.19: Stress Vs Strain plot for 2.0" core filled cylinders with 2 layers of CFRP and GFRP wrap

\subsection{Theoretical Analysis of Confinement for Timber Cylinders}

Effect of confinement on compressive strength is theoretically determined by modifying the confinement equation for concrete suitably for wood.

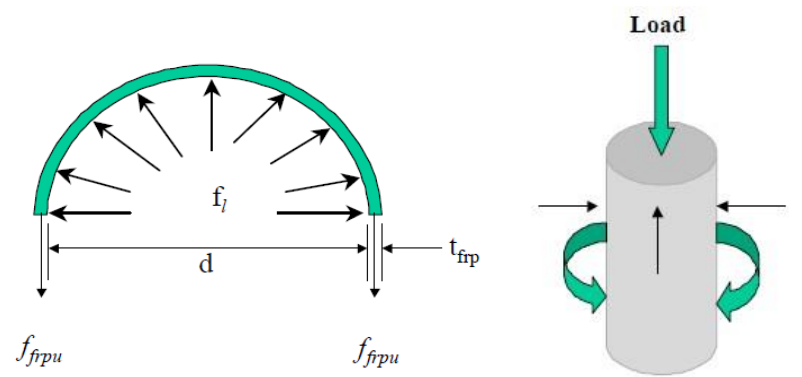

Figure 5.20: Schematic diagram of confined member (left) and effect of confinement (right)

The equation for confinement by FRP in concrete is

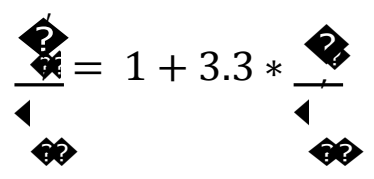

$(\mathrm{ACl} 440.2 \mathrm{R}-08)$

The ratio of lateral confinement by FRP wraps to that of compressive strength of unconfined wood is multiplied by a factor to make this equation applicable for wood. This factor is ratio of elastic modulus of wood to that of elastic modulus for concrete. 
The modified equation for confinement in timber would be

where,

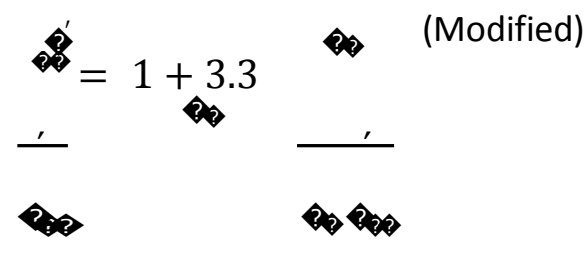

$?=$ Compressive strength of confined wood

$\lambda_{1}^{\prime}=$ Compressive strength of unconfined wood

= Lateral confined pressure by FRP wraps $=$

Podulus of elasticity of FRP

$n=$ Number of layers; 1,2 , and 3

$\overrightarrow{2}=$ Thickness of FRP fabric

$\epsilon=$ Effective failure strain of fabric $=$

$P_{\epsilon} \in$

$\vec{t}=$ Strain efficiency factor $=0.55$

$\epsilon=$ Ultimate failure strain of fabric $=.014$ to 0.016 for carbon and 0.02 to 0.025 for glass

Table 5.12: Experimental Vs Theoretical comparison of confinement of CFRP on timber cylinders

\begin{tabular}{|c|c|c|c|c|c|c|}
\hline & $\begin{array}{l}\text { No. of } \\
\text { Layers }\end{array}$ & $?$ & & Experimental & Theoretical & $\frac{?}{302}$ \\
\hline \multirow{3}{*}{ Carbon } & 1 & 4566.73 & 1039.50 & 84.255 & 78 & 1.09 \\
\hline & 2 & 4566.73 & 2079.00 & 84.407 & 98 & 0.86 \\
\hline & 3 & 4566.73 & 3118.50 & 91.119 & 118 & 0.77 \\
\hline
\end{tabular}

Table 5.13: Experimental Vs Theoretical comparison of confinement of GFRP on timber cylinders

\begin{tabular}{|c|c|c|c|c|c|c|}
\hline & $\begin{array}{l}\text { No. of } \\
\text { Layers }\end{array}$ & ? & 2 & Experimental & Theoretical & $\frac{?}{3020}$ \\
\hline \multirow[t]{2}{*}{ Glass } & $\begin{array}{l}1 \\
2\end{array}$ & $\begin{array}{l}4566.73 \\
4566.73\end{array}$ & $\begin{array}{c}771.21 \\
1542.42\end{array}$ & $\begin{array}{c}- \\
84.407\end{array}$ & $\begin{array}{l}81 \\
87\end{array}$ & $\begin{array}{c}- \\
0.97\end{array}$ \\
\hline & 3 & 4566.73 & 2313.63 & 75.223 & 102 & 0.73 \\
\hline
\end{tabular}


$>$ Tables 5.12 and 5.13 show experimental to theoretical comparison of confinement strength of FRP in timber. In CFRP wrap 1-layer specimen has a ratio greater than 1 which indicates over prediction of theoretical value.

$>$ In CFRP wrap 2-layer specimen has almost equal to one which means experimental and theoretical prediction hold good

$>$ The confinement ratio in 3 layer samples for both wraps is way less than one, which indicates over prediction of theoretical value.

$>$ It can be concluded that experimental and theoretical values for 1 and 2 layers of CFRP are within $15 \%$ and the effectiveness of confinement is not significant with the use of 3 layers with both CFRP and GFRP. 


\section{Chapter 6. FLEXURAL TESTING OF FRP STRENGTHENED TIMBER BEAMS}

\subsection{Introduction}

All the test results for the beams obtained from the experimental work are by four-point flexural loading. Fifteen timber boards all together are tested with and without CFRP reinforcement. The results obtained from strengthening beams is compared to respective control specimen to determine the change in load carrying capacity, stiffness and strength. The effect of span variation and cross-section on performance of the beams is studied. Dimensions of all the boards and beams are tabulated clearly in Chapter 3. The glued board's specifications are also tabulated in the prior chapter. All the boards glued and non-glued are tested for about 40\% load initially without FRP and then to failure with FRP. Necessary graphs and tables are put to describe the experimental data.

\subsection{Results of Non-Glued and Glued Timber Beam Tests:}

Glued and solid beams are tested for various span to depth ratios. Reinforcement is also provided on the tension side for the beam to examine the variations in capacity and flexural rigidity

\subsubsection{Flexural Testing of Board B- 2 x 10}

Four un-strengthened timber boards are loaded to $40 \%$ of the theoretical failure load in four-point bending. The aim of this experiment is to understand the variations in stiffness of the beams with variation in the span. All the data i.e. load, strains induced, stresses, deflections are tabulated below in Table 6.1. Table 6.2 shows the comparison for theoretical and experimental calculations. 


\section{Effect of span variation and FRP reinforcement on 2 x 10 beams}

Two Single board with dimensions 2.0" x 10.0" are tested in four point flexure loading. Higher span beams or boards, 12 feet long exhibit lesser stiffness than 7.0 feet span ones. It can be clearly understood from the graph below that shorter span beams have relatively lower deflections than longer span beams, and hence gives higher slope to the curve in Load Vs Deflection (P Vs $\delta$ ).

Table 6.1: Experimental results for the $2 \times 10$ single board at varying spans

\begin{tabular}{|c|c|c|c|c|c|c|c|}
\hline \multirow[t]{3}{*}{ Specimen } & \multirow{3}{*}{$\begin{array}{l}\text { Applied } \\
\text { Load } \\
\text { (lbs.) }\end{array}$} & \multicolumn{6}{|c|}{ Results under Max. Load } \\
\hline & & \multicolumn{2}{|c|}{ Deflection (in) } & \multirow{2}{*}{$\begin{array}{l}\text { Compressiv } \\
\text { e Strain }\end{array}$} & \multirow{2}{*}{$\begin{array}{l}\text { Tensile } \\
\text { Strain }\end{array}$} & \multirow{2}{*}{$\begin{array}{l}\text { Shear } \\
\text { Strain }\end{array}$} & \multirow{2}{*}{$\begin{array}{c}\text { Stress } \\
\text { (psi) }\end{array}$} \\
\hline & & $\mathrm{L} / 2$ & $\mathrm{~L} / 3$ & & & & \\
\hline \multirow{2}{*}{$\begin{array}{c}\text { B - } 2 \text { x } 10- \\
7.0 \mathrm{~S}-\mathrm{NW}- \\
40 \% \\
\text { Capacity }\end{array}$} & 2951.645 & 0.502 & 0.433 & \multirow{2}{*}{1118.356} & \multirow{2}{*}{1060.491} & \multirow{2}{*}{894.16} & 1930.376 \\
\hline & 3200.134 & 0.373 & 0.247 & & & & 2092.888 \\
\hline \multirow{2}{*}{$\begin{array}{c}\text { B - } 2 \text { x } 10- \\
11.0 \mathrm{~S}-\mathrm{NW} \\
-40 \% \\
\text { Capacity }\end{array}$} & 1971.121 & 0.462 & 0.417 & \multirow{2}{*}{1263.642} & \multirow{2}{*}{1088.24} & \multirow{2}{*}{446.53} & 2010.543 \\
\hline & $\begin{array}{c}1954.33 \\
2\end{array}$ & $\begin{array}{c}0.54 \\
2\end{array}$ & 0.504 & & & & $\begin{array}{c}2009.05 \\
3\end{array}$ \\
\hline
\end{tabular}

B - 2 x 10 - 7.0S -NW - 40\% beam specimens have higher slope than other beams B - 2 x $10-11.0 \mathrm{~S}-\mathrm{NW}-40 \%$, which indicates resistance offered by the beam against load applied.

The beams behave linear to the applied load which defines the elastic behavior and also confirms that the $40 \%$ of expected failure load is well within the elastic zone for the timber beams 


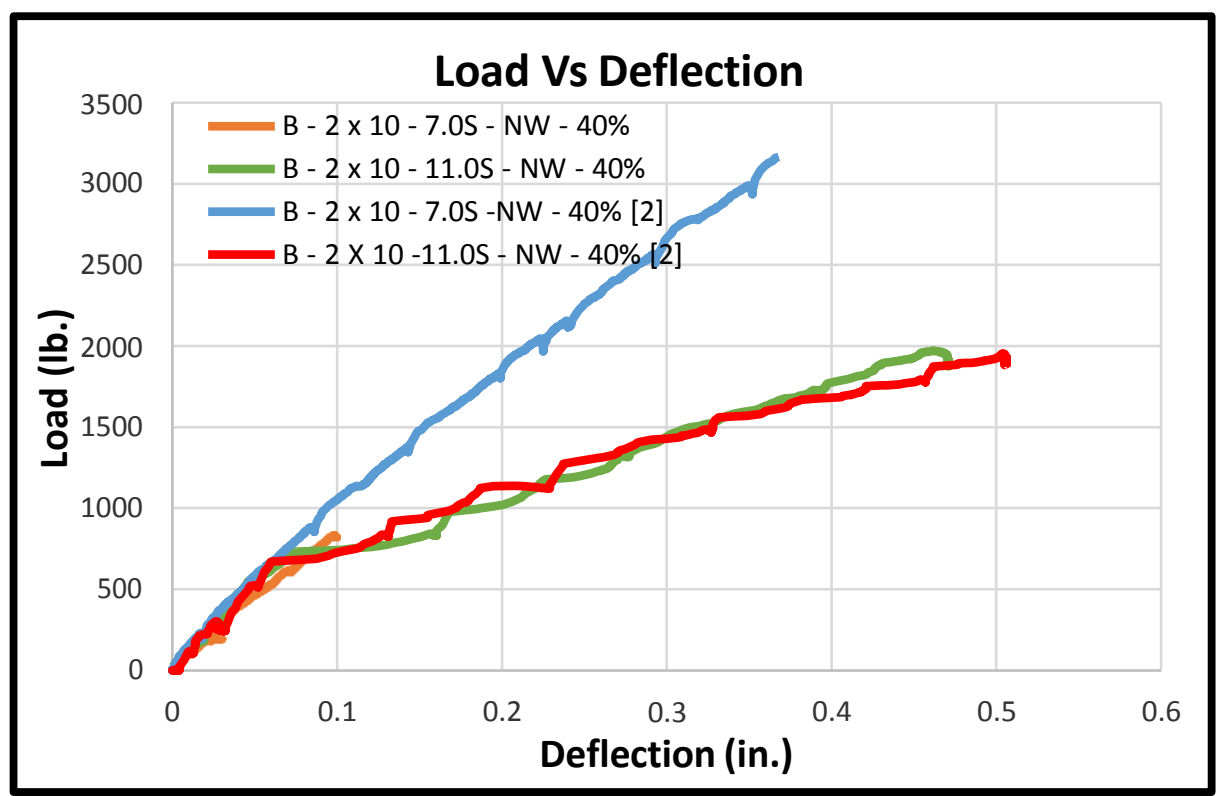

Figure 6.1: Load Vs Deflection plot for $2 \times 10$ individual timber boards

Table 6.2: Flexural rigidity and moment capacity for the $2 \times 10$ beams

\begin{tabular}{|c|c|c|c|c|}
\hline \multirow{2}{*}{ Specimen } & \multicolumn{2}{|c|}{$\begin{array}{c}\text { Flexural Rigidity (EI) } \\
\left(10^{8}\right)\end{array}$} & \multirow{2}{*}{$\begin{array}{c}\text { EI Ratio } \\
\text { (Exp. } \\
\text { /Theo. })\end{array}$} & 2) \\
\hline & 1.81 & 2.0 & 0.90 & 41291.95 \\
\hline $\begin{array}{c}\text { B - 2 x 10 - } \\
7.0 \text { S -NW - } \\
40 \% \\
\text { Capacity }\end{array}$ & 1.80 & 2.0 & 0.89 & 44768.18 \\
\cline { 2 - 3 } $\begin{array}{c}\text { B - 2 x 10 - } \\
11.0 \text { S -NW } \\
-40 \%\end{array}$ & 2.94 & 2.0 & 1.46 & 43006.77 \\
\cline { 2 - 3 } Capacity & 2.90 & 2.0 & 1.44 & 42974.9 \\
\hline
\end{tabular}




\subsubsection{Flexural Testing of Glued B - 2, 2 x 10 Beam With and Without FRP}

12.1 feet long glued beams are tested for two spans; 7.0 feet and 11.0 feet in 4-point bending to understand the behavior at $40 \%$ of the load. Reinforced beams are tested for 7.0 feet and 11.0 feet and allowed to fail at 11.0 feet span.

Table 6.3: Experimental results for the $2 \times 10$ single board at varying spans

\begin{tabular}{|c|c|c|c|c|c|c|c|}
\hline Description & $\begin{array}{l}\text { Applied } \\
\text { Load } \\
\text { (lbs.) }\end{array}$ & $\begin{array}{c}\text { Max } \\
\text { Comp } \\
\text { strain } \\
(\mu \mathrm{e})\end{array}$ & $\begin{array}{c}\text { Max } \\
\text { Tension } \\
\text { strain } \\
(\mu \mathrm{e})\end{array}$ & $\begin{array}{l}\text { Max } \\
\text { shear } \\
\text { strain } \\
(\mu \mathrm{e})\end{array}$ & $\begin{array}{c}\text { Max } \\
\text { Deflection } \\
\text { (L/2) } \\
\text { (in.) }\end{array}$ & $\begin{array}{c}\text { Max } \\
\text { Deflection } \\
\text { (L/3) } \\
\text { (in.) }\end{array}$ & $\begin{array}{c}\text { Stress } \\
\text { (psi) }\end{array}$ \\
\hline $\begin{array}{c}\mathrm{B}-2 \times 10- \\
7.0 \mathrm{~S}-\mathrm{NW}- \\
40 \%-2 \mathrm{G}\end{array}$ & 6279.382 & 987.051 & 993.649 & 744.393 & 0.096 & 0.135 & 2055.554 \\
\hline $\begin{array}{l}\mathrm{B}-2 \times 10- \\
11.0 \mathrm{~S}-\mathrm{NW} \\
-40 \%-2 \mathrm{G}\end{array}$ & 3945.601 & +932.814 & 1036.55 & 469.11 & 0.420 & 0.433 & 2028.039 \\
\hline $\begin{array}{l}\mathrm{B}-2 \times 10- \\
7.0 \mathrm{~S}-\mathrm{W}- \\
40 \%-2 \mathrm{G}\end{array}$ & 9200.806 & 1557.332 & 1226.34 & 1317.774 & 0.445 & 0.407 & 3008.664 \\
\hline $\begin{array}{l}\text { B - } 2 \text { × } 10- \\
11.0 \mathrm{~S}-\mathrm{W}- \\
100 \%-2 \mathrm{G}\end{array}$ & 15308.93 & 3382.125 & $\begin{array}{c}- \\
3863.33\end{array}$ & 4268.733 & 1.785 & - & 7868.791 \\
\hline
\end{tabular}

2-glued $2 \times 10$ beam specimen is tested for two spans 7 feet and 11 feet. It is understood from the graph that span length changes the slope of the Load Vs Deflection plot (P Vs $\delta$ ) but ultimately doesn't effect the flexural stiffness (EI) of the beams.

Beam specimen $\mathrm{B}-2 \times 10-11.0 \mathrm{~S}-\mathrm{W}-100 \%-2 \mathrm{G}$ is theoretically calculated to carry a load of $9558 \mathrm{lbs}$. and $14940 \mathrm{lbs}$. without and with reinforcement on tension side whereas, experimentally it sustained 15304.93 lbs. Flexural reinforcement (CFRP) has enhanced the beam $(\mathrm{B}-2 \times 10-11.0 \mathrm{~S}-\mathrm{W}-100 \%-2 \mathrm{G})$ strength by $60 \%$. 
At 11.0 feet span, CFRP reinforced beam has higher stiffness than the beam having no reinforcement. This highlights how FRP can contribute in strength enhancement of timber beams in flexure.

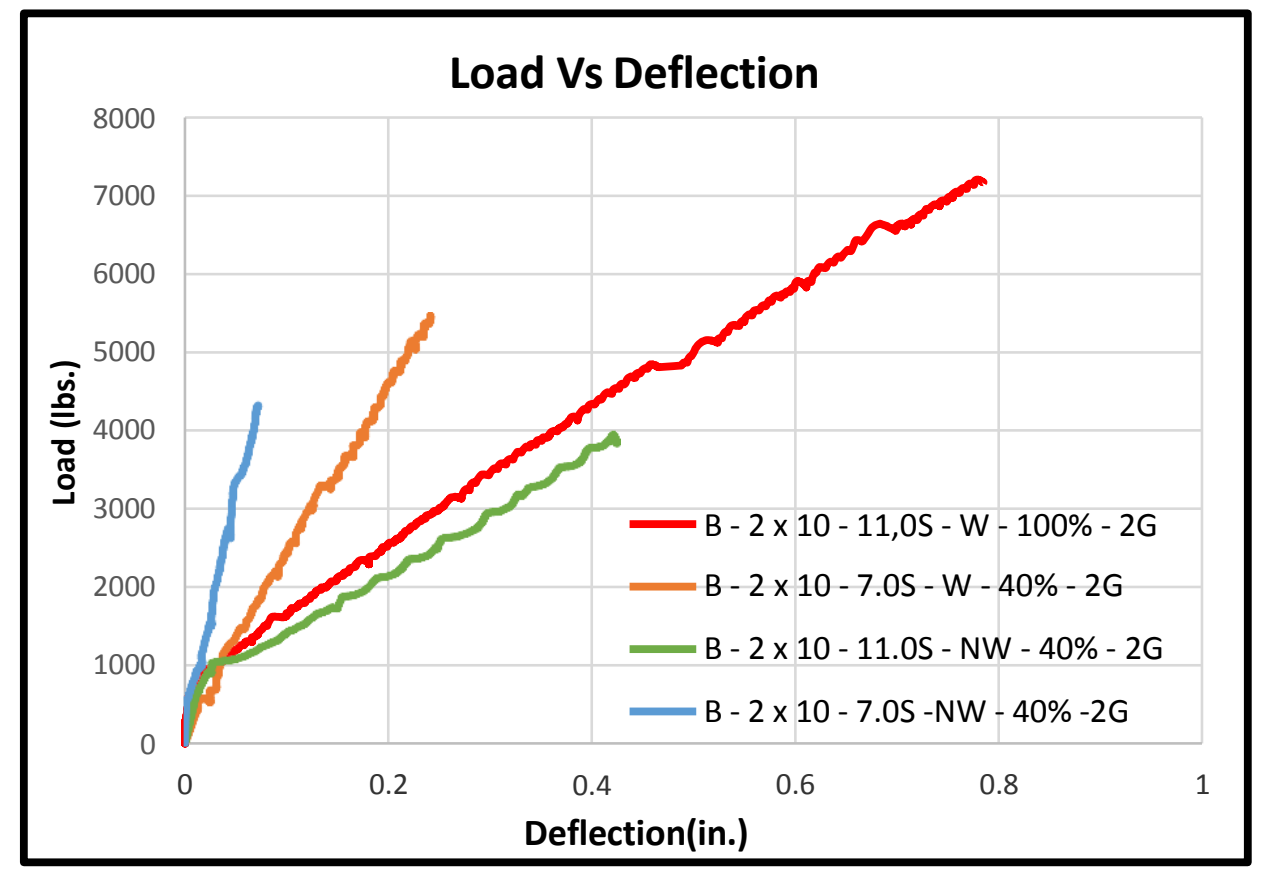

Figure 6.2: Load Vs Deflection plot for 2- $2 \times 10$ beams with FRP 
Table 6.4: Flexural rigidity and moment capacity for the 2-2 x 10 beam

\begin{tabular}{|c|c|c|c|c|c|c|}
\hline \multirow[t]{2}{*}{ Specimen } & \multicolumn{2}{|c|}{$\left.(2) i^{2}\right)$} & \multirow{2}{*}{$\begin{array}{l}\text { EI Ratio } \\
\text { (Exp. } \\
\text { /Theo.) }\end{array}$} & \multicolumn{2}{|c|}{$($ ar? $-i)$} & \multirow[t]{2}{*}{$\begin{array}{l}\text { Moment } \\
\text { Ratio }\end{array}$} \\
\hline & $\begin{array}{c}\text { Experiment } \\
\text { al } \\
\left(10^{8}\right)\end{array}$ & $\begin{array}{c}\text { Theoretica } \\
1 \\
\left(10^{8}\right)\end{array}$ & & $\begin{array}{c}\text { Experiment } \\
\text { al } \\
\text { (lbs.-in) }\end{array}$ & $\begin{array}{c}\text { Theoretica } \\
1 \\
\text { (lbs.-in) }\end{array}$ & \\
\hline $\begin{array}{c}\mathrm{B}-2 \times 10- \\
7.0 \mathrm{~S}-\mathrm{NW}- \\
40 \%-2 \mathrm{G}\end{array}$ & 12.1 & 3.16 & & 65933.5 & - & - \\
\hline $\begin{array}{c}\mathrm{B}-2 \times 10- \\
11.0 \mathrm{~S}-\mathrm{NW}- \\
40 \%-2 \mathrm{G}\end{array}$ & 6.2 & 3.16 & & 86803.22 & - & - \\
\hline $\begin{array}{c}\mathrm{B}-2 \times 10- \\
7.0 \mathrm{~S}-\mathrm{W}-40 \% \\
-2 \mathrm{G}\end{array}$ & 2.3 & & & 128811.3 & - & - \\
\hline $\begin{array}{l}\mathrm{B}-2 \times 10- \\
11.0 \mathrm{~S}-\mathrm{W}- \\
100 \%-2 \mathrm{G}\end{array}$ & 3.7 & & & 336796.5 & 328680 & 1.02 \\
\hline
\end{tabular}




\subsubsection{Flexural testing of glued $B-3,2 \times 10$ beam with and without FRP}

Three timber beams glued together are tested in flexure at different spans to depth ratios by introducing FRP in the tension region of the beam. The effect of span variation and FRP on stiffness and moment capacities of the beam are investigated.

\begin{tabular}{|c|c|c|c|c|c|c|c|}
\hline Description & $\begin{array}{c}\text { Max } \\
\text { Load } \\
\text { (lbs.) }\end{array}$ & $\begin{array}{c}\text { Max } \\
\text { Comp } \\
\text { strain } \\
(\mu \mathrm{e})\end{array}$ & $\begin{array}{c}\text { Max } \\
\text { Tension } \\
\text { strain } \\
(\mu \mathrm{e})\end{array}$ & $\begin{array}{c}\text { Max } \\
\text { shear } \\
\text { strain } \\
(\mu \mathrm{e})\end{array}$ & $\begin{array}{c}\text { Max } \\
\text { Deflection } \\
(\mathrm{L} / 2) \\
(\mathrm{in} .)\end{array}$ & $\begin{array}{c}\text { Max } \\
\text { Deflection } \\
(\mathrm{L} / 3) \\
(\mathrm{in} .)\end{array}$ & $\begin{array}{c}\text { Stress } \\
(\mathrm{psi})\end{array}$ \\
\hline $\begin{array}{c}\mathrm{B}-2 \times 10- \\
7.0 \mathrm{~S}-\mathrm{NW}- \\
40 \%-3 \mathrm{G}\end{array}$ & 9338.4 & 1317.94 & 1482.234 & 614.352 & 0.173 & 0.163 & 2036.521 \\
\hline $\begin{array}{c}\mathrm{B}-2 \times 10- \\
11.0 \mathrm{~S}-\mathrm{NW}- \\
40 \%-3 \mathrm{G}\end{array}$ & 5862.9 & 1379.8 & 1482.366 & 424.126 & 0.538 & 0.432 & 2005.144 \\
\hline $\begin{array}{c}\mathrm{B}-2 \times 10- \\
7.0 \mathrm{~S}-\mathrm{W}- \\
40 \%-3 \mathrm{G}\end{array}$ & 14274 & 1845.5 & 1915.1 & 923.764 & 0.419 & 0.074 & 3111.88 \\
\hline $\begin{array}{c}\mathrm{B}-2 \times 10- \\
11.0 \mathrm{~S}-\mathrm{W}- \\
100 \%-3 \mathrm{G}\end{array}$ & 24926.5 & 3724.5 & 3649.0 & - & 1.333 & 0.024 & 8524.735 \\
\hline
\end{tabular}




\begin{tabular}{|c|c|c|c|c|c|c|}
\hline \multirow[t]{2}{*}{ Specimen } & \multicolumn{2}{|c|}{$\left(\right.$ a? $\left.i^{2}\right)$} & \multirow{2}{*}{$\begin{array}{l}\text { EI Ratio } \\
\text { (Exp. } \\
\text { /Theo.) }\end{array}$} & \multicolumn{2}{|c|}{$(6)-i)$} & \multirow[t]{2}{*}{$\begin{array}{c}\text { Moment } \\
\text { Ratio }\end{array}$} \\
\hline & $\begin{array}{c}\text { Experiment } \\
\text { al } \\
\left(10^{8}\right)\end{array}$ & $\begin{array}{c}\text { Theoretica } \\
1 \\
\left(10^{8}\right)\end{array}$ & & $\begin{array}{c}\text { Experiment } \\
\text { al } \\
\text { (lbs.-in) }\end{array}$ & $\begin{array}{c}\text { Theoretica } \\
1 \\
\text { (lbs.-in) }\end{array}$ & \\
\hline $\begin{array}{c}\mathrm{B}-2 \times 10- \\
7.0 \mathrm{~S}-\mathrm{NW}- \\
40 \%-3 \mathrm{G}\end{array}$ & 15.04 & 4.22 & & 130732 & - & - \\
\hline $\begin{array}{c}\mathrm{B}-2 \times 10- \\
11.0 \mathrm{~S}-\mathrm{NW}- \\
40 \%-3 \mathrm{G}\end{array}$ & 7.41 & 4.22 & & 128983 & - & - \\
\hline $\begin{array}{c}\mathrm{B}-2 \times 10- \\
7.0 \mathrm{~S}-\mathrm{W}-40 \% \\
-3 \mathrm{G}\end{array}$ & 3.4 & & & 199836 & - & - \\
\hline $\begin{array}{l}\text { B - } 2 \times 10- \\
11.0 S-W- \\
100 \%-3 G\end{array}$ & 11.6 & & & 548383 & 490116 & 1.11 \\
\hline
\end{tabular}

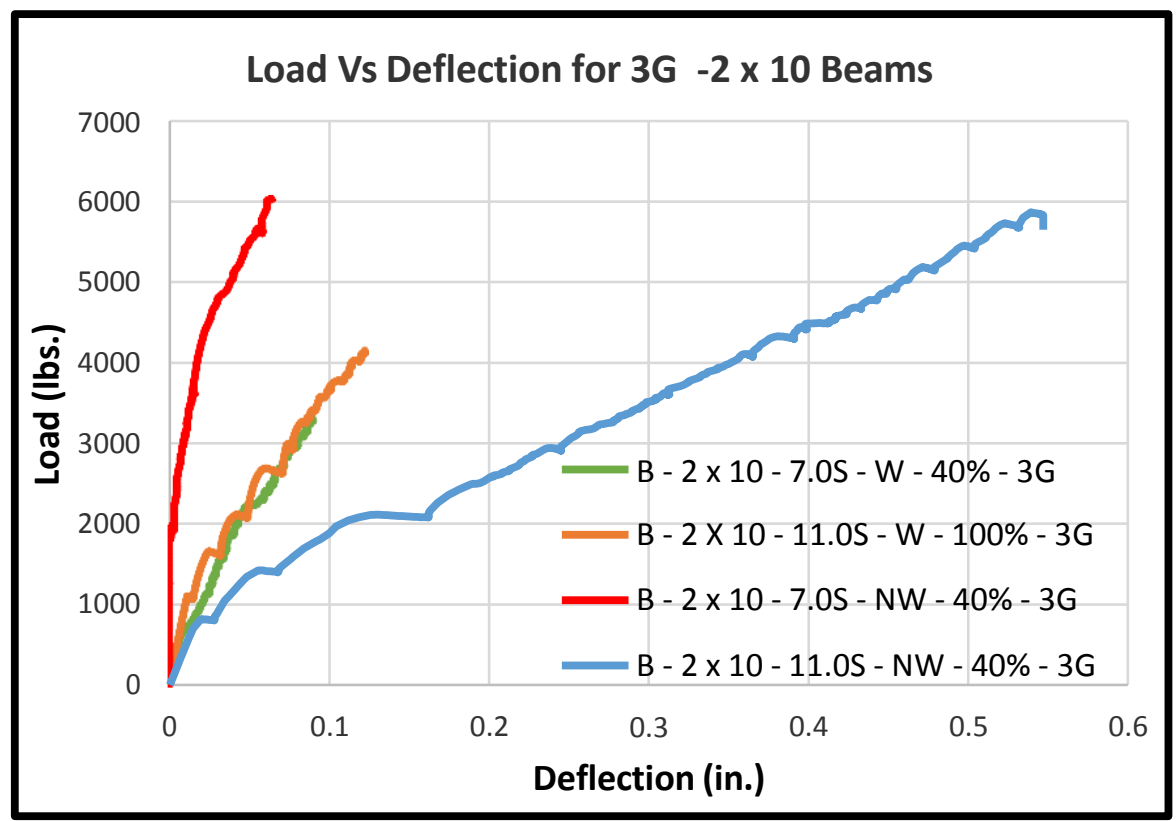


6.2.4 Flexural testing of glued $B-2,2 \times 12$ beam with and without FRP

\begin{tabular}{|c|c|c|c|c|c|c|c|}
\hline Description & $\begin{array}{l}\text { Max } \\
\text { Load } \\
\text { (lbs.) }\end{array}$ & $\begin{array}{l}\text { Max } \\
\text { Comp } \\
\text { strain } \\
(\mu \mathrm{e})\end{array}$ & $\begin{array}{c}\text { Max } \\
\text { Tension } \\
\text { strain } \\
(\mu \mathrm{e})\end{array}$ & $\begin{array}{l}\text { Max } \\
\text { shear } \\
\text { strain } \\
(\mu \mathrm{e})\end{array}$ & $\begin{array}{c}\text { Max } \\
\text { Deflection } \\
(\mathrm{L} / 2) \text { (in.) }\end{array}$ & $\begin{array}{c}\text { Max } \\
\text { Deflection } \\
\text { (L/3) (in.) }\end{array}$ & $\begin{array}{c}\text { Stress } \\
\text { (psi) }\end{array}$ \\
\hline $\begin{array}{c}\mathrm{B}-2 \times 12- \\
7.0 \mathrm{~S}-\mathrm{NW}- \\
40 \%\end{array}$ & 4680.994 & 846.263 & 1023.039 & 355.535 & 0.184 & 0.194 & 2068.999 \\
\hline $\begin{array}{c}\mathrm{B}-2 \times 12- \\
9.0 \mathrm{~S}-\mathrm{NW}- \\
40 \%\end{array}$ & 3556.078 & 825.177 & 890.901 & 281.756 & 0.197 & 0.232 & 2019.852 \\
\hline $\begin{array}{c}\mathrm{B}-2 \times 12- \\
11.0 \mathrm{~S}-\mathrm{NW} \\
-40 \%\end{array}$ & 2830.759 & 831.445 & 888.109 & 276.707 & 0.337 & 0.364 & 1967.378 \\
\hline $\begin{array}{c}\mathrm{B}-2 \times 12- \\
7.0 \mathrm{~S}-\mathrm{W}- \\
40 \%\end{array}$ & & & & & & & \\
\hline $\begin{array}{c}\mathrm{B}-2 \times 12- \\
9.0 \mathrm{~S}-\mathrm{W}- \\
40 \%\end{array}$ & & & & & & & \\
\hline $\begin{array}{c}\mathrm{B}-2 \times 12- \\
11.0 \mathrm{~S}-\mathrm{W}- \\
100 \%\end{array}$ & & & & & & & \\
\hline
\end{tabular}




\begin{tabular}{|c|c|c|c|c|c|c|}
\hline \multirow[t]{2}{*}{ Specimen } & \multicolumn{2}{|c|}{$\left(i^{2}\right)$} & \multirow{2}{*}{$\begin{array}{l}\text { EI Ratio } \\
\text { (Exp. } \\
\text { /Theo.) }\end{array}$} & \multicolumn{2}{|c|}{$(2)$} & \multirow[t]{2}{*}{$\begin{array}{l}\text { Moment } \\
\text { Ratio }\end{array}$} \\
\hline & $\begin{array}{c}\text { Experiment } \\
\text { al } \\
\left(10^{8}\right)\end{array}$ & $\begin{array}{c}\text { Theoretica } \\
1 \\
\left(10^{8}\right)\end{array}$ & & $\begin{array}{c}\text { Experiment } \\
\text { al } \\
\text { (lbs.-in) }\end{array}$ & $\begin{array}{c}\text { Theoretica } \\
1 \\
\text { (lbs.-in) }\end{array}$ & \\
\hline $\begin{array}{c}\mathrm{B}-2 \times 12- \\
7.0 \mathrm{~S}-\mathrm{NW}- \\
40 \%\end{array}$ & & & & 130928.8 & - & - \\
\hline $\begin{array}{c}\mathrm{B}-2 \times 12- \\
9.0 \mathrm{~S}-\mathrm{NW}- \\
40 \%\end{array}$ & & & & 127818.8 & - & - \\
\hline $\begin{array}{c}\text { B - } 2 \times 12- \\
11.0 \mathrm{~S}-\mathrm{NW}- \\
40 \%\end{array}$ & & & & 124498.1 & - & - \\
\hline $\begin{array}{c}\text { B - } 2 \times 12- \\
7.0 S-W-40 \%\end{array}$ & & & & 160637.96 & & \\
\hline $\begin{array}{c}\text { B - } 2 \times 12- \\
9.0 \mathrm{~S}-\mathrm{W}-40 \%\end{array}$ & & & & 173653.45 & & \\
\hline $\begin{array}{c}\mathrm{B}-2 \times 12- \\
11.0 \mathrm{~S}-\mathrm{W}- \\
100 \%\end{array}$ & & & & 582726.76 & 476124 & 1.22 \\
\hline
\end{tabular}

\subsection{Results on solid timber beams}

Two beams with different dimensions and varying spans are tested in four point bending to analyze the flexural behavior, stiffness, capacities and deviations in their performance with and without reinforcement. The solid beams experimented and reported in this section are:

- $4 \times 4$

- $6 \times 6$

$4 \times 4$ are tested for 5 feet and 7 feet and $6 \times 6$ beams are tested for two spans 7 feet and 11 feet with and without carbon FRP. 6 X 6 beams are treated and are 12 feet long whereas, $4 \times 4$ beams are untreated and 8 feet long. 


\subsubsection{Flexural testing of Solid beams with and without FRP}

B $-4 \times 4$

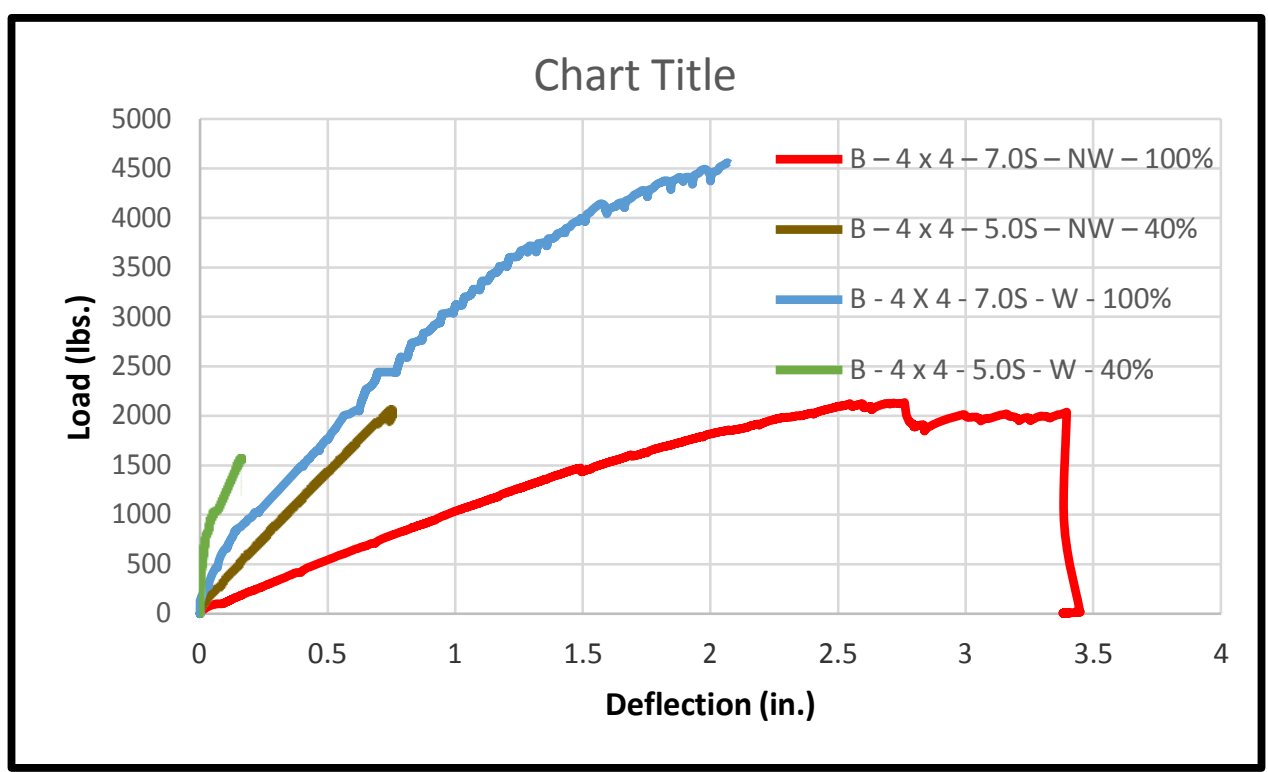

\begin{tabular}{|c|c|c|c|c|c|c|c|}
\hline Description & $\begin{array}{c}\text { Max } \\
\text { Load } \\
(\mathrm{lbs} .)\end{array}$ & $\begin{array}{c}\text { Max } \\
\text { Comp } \\
\text { strain } \\
(\mu \mathrm{e})\end{array}$ & $\begin{array}{c}\text { Max } \\
\text { Tension } \\
\text { strain } \\
(\mu \mathrm{e})\end{array}$ & $\begin{array}{c}\text { Max } \\
\text { shear } \\
\text { strain } \\
(\mu \mathrm{e})\end{array}$ & $\begin{array}{c}\text { Max } \\
\text { Deflection } \\
(\mathrm{L} / 2)(\mathrm{in} .)\end{array}$ & $\begin{array}{c}\text { Max } \\
\text { Deflection } \\
(\mathrm{L} / 3)(\mathrm{in} .)\end{array}$ & $\begin{array}{c}\text { Stress } \\
(\mathrm{psi})\end{array}$ \\
\hline $\begin{array}{c}\text { B - 4 x 4 - } \\
5.0 \mathrm{~S}-\mathrm{NW}- \\
40 \%\end{array}$ & 2058.428 & - & 2113.451 & 713.775 & 0.749 & 0.663 & 2879.741 \\
\hline $\begin{array}{c}\text { B - } 4 \text { x 4 - } \\
7.0 \mathrm{~S}-\mathrm{NW}- \\
100 \%\end{array}$ & 2128.945 & - & 3195.863 & 892.94 & 2.761 & 2.876 & 4170.603 \\
\hline
\end{tabular}




\begin{tabular}{|c|c|c|c|c|c|c|}
\hline \multirow[t]{2}{*}{ Specimen } & \multicolumn{2}{|c|}{ Deflection } & \multirow{2}{*}{$\begin{array}{c}\text { Deflectio } \\
\text { n ratio } \\
\text { (in.) }\end{array}$} & \multicolumn{2}{|c|}{ Moment } & \multirow{2}{*}{$\begin{array}{l}\text { Moment } \\
\text { ratio }\end{array}$} \\
\hline & $\begin{array}{c}\text { Experiment } \\
\text { al } \\
\text { (in) }\end{array}$ & $\begin{array}{c}\text { Theoretica } \\
1 \\
\text { (in) }\end{array}$ & & $\begin{array}{c}\text { Experiment } \\
\text { al } \\
\text { (lbs.-in) }\end{array}$ & $\begin{array}{c}\text { Theoretica } \\
1 \\
\text { (lbs.-in) }\end{array}$ & \\
\hline $\begin{array}{c}\mathrm{B}-4 \times 4-5.0 \mathrm{~S}- \\
\mathrm{NW}-40 \%\end{array}$ & 0.749 & & & 20578.15 & 20584.28 & - \\
\hline $\begin{array}{c}\mathrm{B}-4 \times 4-7.0 \mathrm{~S}- \\
\mathrm{NW}-100 \%\end{array}$ & 2.761 & & & 29802.43 & 29805.23 & 0.99 \\
\hline $\begin{array}{c}B-4 \times 4-5.0 \mathrm{~S}- \\
\mathrm{NW}-40 \%\end{array}$ & & & & 15681.7 & & \\
\hline $\begin{array}{c}\mathrm{B}-4 \times 4-7.0 \mathrm{~S}- \\
\text { NW }-100 \%\end{array}$ & & & & 66897.25 & & \\
\hline
\end{tabular}

\section{Effect of FRP wrap on stiffness of the timber beams}

4 x 4 specimen is experimented for two spans 5 feet and 7 feet. It is understood from the above graph that span length decreases the stiffness of the beam. B-4x4-7.0S-NW-40\% specimen has a

span of 7 feet without wrap and a flexural stiffness value of $0.8>10^{7} ? \geqslant-i^{2}$. The other beam B-4x4-7.0S-W-40\% specimen with same span and a wrap on the tension side has higher stiffness of $2.4 \geqslant 10^{7} ?-i^{2}$. It is clear that the stiffness of the beam due to FRP on tension side multiplied by 3 folds. Similarly for the 5 feet beam B-4x4-5.0S-W-40\% the flexural stiffness is

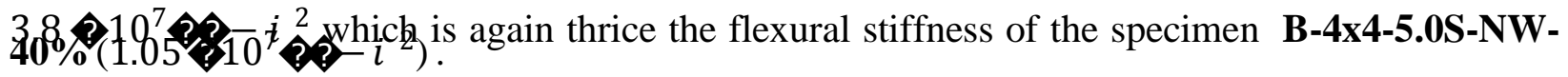
Effect of span variation on flexural strength and stiffness of $4 \times 4$ solid beam

B-4 $\times$ 4-5.0S-NW-40\% and B-4 $\times$ 4-7.0S-NW-40\% samples have been tested and from the flexural stiffness values it is understood that with the increase of span the stiffness decreases. There is a $30 \%$ increase in stiffness of the beam when the span is changed from 7 feet to 5 feet. FRP present on the tension side holds the sample stiff and increases the capacity thereby increasing the 
stiffness of the specimen. Similarly, B-4x4-7.0S-W-100\% and B-4x4-5.0S-W-100\% have the similar reasoning along with the effect of FRP in the tension side. In this case the stiffness went up $58 \%$ and this increase is due to presence of FRP. From this it can be concluded that span variation has an effect on performance i.e. larger spans reduce the stiffness.

\section{Stiffness of $B-4 \times 4$ timber beam specimen}

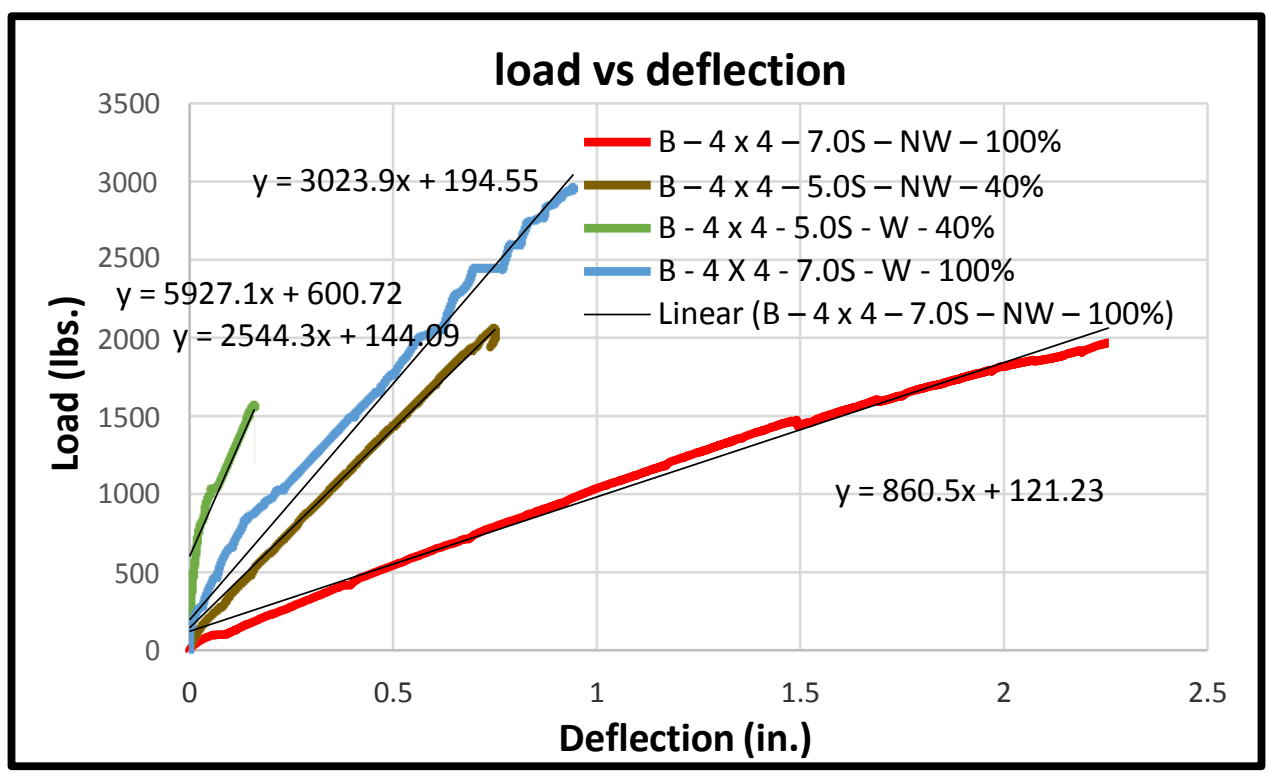

Stiffness of any beams is determined from Load Vs Deflection plot. Here, in this case primarily two factors i.e. span of the beam during the test and the reinforcement on the tension side alter the stiffness.

The specimen B-4 x 4-7.0S-NW-100\% has the lowest stiffness among the four specimens due to higher spans and lack of reinforcement. 4 x 4-7.0S-W-100\% has higher stiffness than $4 \times$ 4-7.0S-NW-100\% due to FRP on the tension side.

$4 \times$ 4-5.0S-NW-40\% has less stiffness than $4 \times$ 4-7.0S-W-100\% as FRP in the later one takes over the control of the beam eliminating factors like higher spans. 
Beam B-4x4-5.0S-W-40\% has the highest stiffness among all the four beams. This beam has the least span and also additional reinforcement compared to others and from this it can be concluded that span and reinforcement can alter the stiffness.

\subsubsection{Flexural testing of Solid $6 \times 6$ beam with and without FRP}

\begin{tabular}{|c|c|c|c|c|c|c|c|}
\hline Description & $\begin{array}{l}\text { Max } \\
\text { Load } \\
\text { (lbs.) }\end{array}$ & $\begin{array}{l}\text { Max } \\
\text { Comp } \\
\text { strain } \\
(\mu \mathrm{e})\end{array}$ & $\begin{array}{c}\text { Max } \\
\text { Tension } \\
\text { strain } \\
(\mu \mathrm{e})\end{array}$ & $\begin{array}{l}\text { Max } \\
\text { shear } \\
\text { strain } \\
(\mu \mathrm{e})\end{array}$ & $\begin{array}{c}\text { Max } \\
\text { Deflection } \\
(\mathrm{L} / 2) \text { (in.) }\end{array}$ & $\begin{array}{c}\text { Max } \\
\text { Deflection } \\
\text { (L/3) (in.) }\end{array}$ & $\begin{array}{c}\text { Stress } \\
(\mathrm{psi})\end{array}$ \\
\hline $\begin{array}{c}\mathrm{B}-6 \times 6- \\
7.0 \mathrm{~S}-\mathrm{NW}- \\
40 \%\end{array}$ & 3918.737 & 2878.54 & 3113.867 & 560.501 & 0.87 & 0.768 & 3107.558 \\
\hline $\begin{array}{c}\text { B - } 6 \text { × } 6- \\
11.0 S-N W \\
-100 \%\end{array}$ & 4912.693 & 7257.88 & 6986.423 & 403.667 & 2.28 & 2.196 & 3895.766 \\
\hline $\begin{array}{c}\mathrm{B}-6 \times 6- \\
7.0 \mathrm{~S}-\mathrm{NW}- \\
40 \%\end{array}$ & 7226.62 & & & & 0.66 & & \\
\hline $\begin{array}{c}\text { B - } 6 \text { × } 6- \\
11.0 S-N W \\
-100 \%\end{array}$ & 5423.10 & & & & 2.00 & & \\
\hline
\end{tabular}

\begin{tabular}{|c|c|c|c|c|c|c|}
\hline \multirow[t]{2}{*}{ Specimen } & \multicolumn{2}{|c|}{ Deflection } & \multirow{2}{*}{$\begin{array}{l}\text { Deflectio } \\
\text { n ratio } \\
\text { (in.) }\end{array}$} & \multicolumn{2}{|c|}{ Moment } & \multirow{2}{*}{$\begin{array}{l}\text { Moment } \\
\text { ratio }\end{array}$} \\
\hline & $\begin{array}{c}\text { Experiment } \\
\text { al } \\
\text { (in) }\end{array}$ & $\begin{array}{c}\text { Theoretica } \\
1 \\
\text { (in) }\end{array}$ & & $\begin{array}{c}\text { Experiment } \\
\text { al } \\
\text { (lbs.-in) }\end{array}$ & $\begin{array}{c}\text { Theoretica } \\
1 \\
\text { (lbs.-in) }\end{array}$ & \\
\hline $\begin{array}{c}B-6 \times 6-7.0 S \\
-N W-40 \%\end{array}$ & 0.871 & & & 86169.99 & 54862.32 & - \\
\hline $\begin{array}{c}B-6 \times 6-11.0 S \\
-N W-100 \%\end{array}$ & 2.282 & & & 108026.3 & & \\
\hline $\begin{array}{c}\mathrm{B}-6 \times 6-7.0 \mathrm{~S} \\
-\mathrm{W}-40 \%\end{array}$ & & & & 101172 & & \\
\hline $\begin{array}{c}\mathrm{B}-6 \times 6-11.0 \mathrm{~S} \\
-\mathrm{W}-100 \%\end{array}$ & & & & 119308 & & \\
\hline
\end{tabular}




\section{Effect of span variations on stiffness}

$6 \times 6$ specimens are tested for 7 feet and 11 feet spans. Figure infers that beams with longer span have reduced stiffness and therefore in this case reach their capacities way before 7.0 feet span ones. In this case B- 6x6-11.0S-W-100\% doesn't have higher stiffness as in for B $-4 \times 4$.

The specimen 6x6-7.0S-NW-40\% and 6x6-11.0S-NW-100\% have stiffness $4.7 \gg 10^{7} ?-i \quad i^{2}$ and $3.8 \geqslant 10^{7}-i^{2} \mathrm{lbs}$./in respectively. With the increase of span from 7.0 to 11.0 feet the sample specimen experienced a reduction in stiffness by 2.5 folds. Similarly, 6 x 6-7.0S-W-40\% and 6 x 6-11.0S-W-100\% have a stiffness of $13679 \mathrm{lbs} . /$ in and $2713.4 \mathrm{lbs} . / \mathrm{in}$ respectively. The stiffness got reduced by four times when the span is maintained at 11.0 feet.

\section{Effect of FRP wrap on stiffness of the timber beams}

External reinforcement definitely has a positive effect and enhances the beams stiffness but at the same time stiffness is dependent on span and cross-section of the beam. From the Graph above the beams with CFRP reinforcement have higher stiffness than ones without irrespective of the span. Hence it is clear that FRP reinforcing, stiffens the beams in flexure and therefore improves their capacity.

The 7.0 feet span beam without FRP (6 x 6-7.0S-NW-40\%) experiences a stiffness increment by 3.515 folds $(251 \%)$ with respect to 11.0 feet span beam (6 x 6-11.0S-NW-100\%). On the other hand, carbon reinforced 7.0 feet beam exhibits 5.041 (404\%) times the stiffness of 11.0 feet beam. From this it undisputedly proved that FRP contributes in stiffening of timber beams. 
Stiffness of B - 6 x 6 timber beam specimen

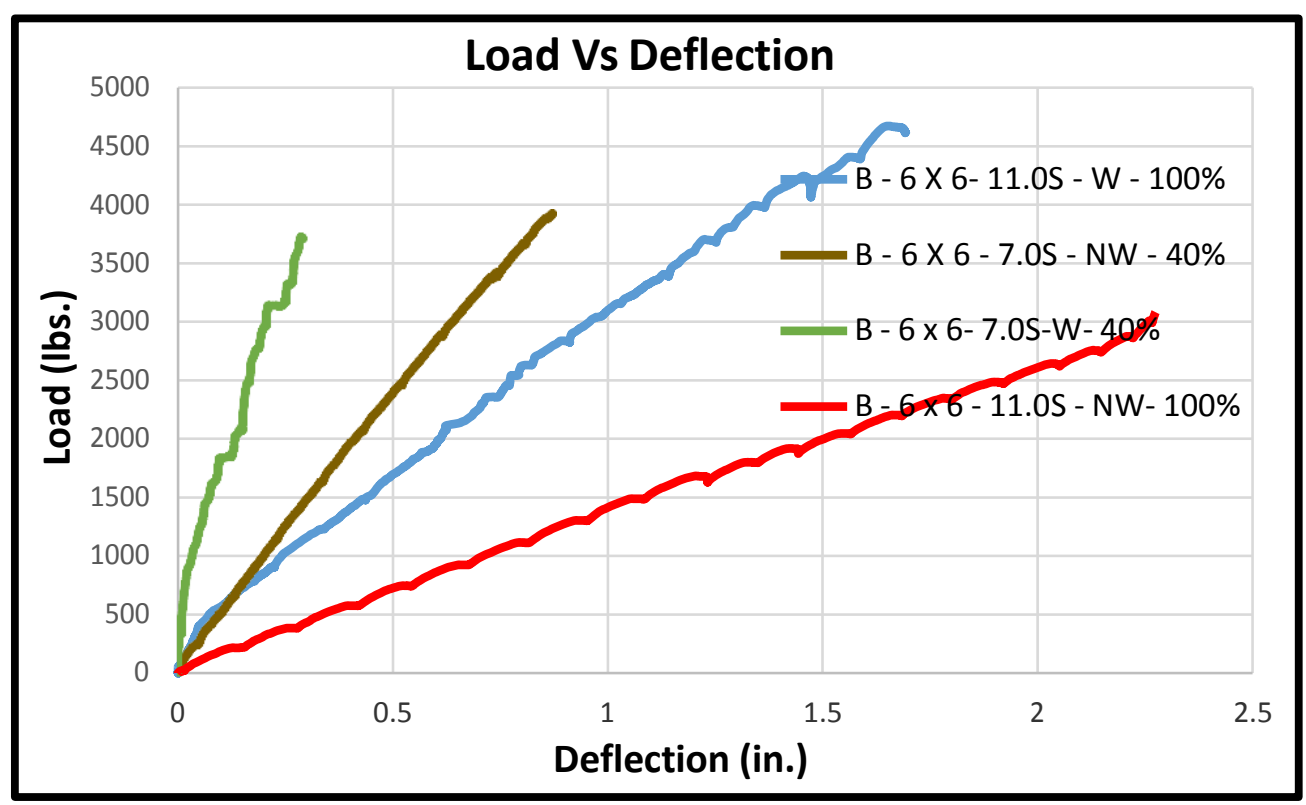

B - 6 x $6-7.0$ S specimen with and without CFRP have been loaded till $40 \%$ of design capacity which is within the elastic limit and the stiffness are 13679 and 4628.5, respectively. The stiffness increased by 2.995 folds (200\%). Similarly, B - 6 x $6-11.0$ S specimen with wrap exhibits an increment of 2.06 times $(106 \%)$ that of stiffness of no wrap beam.

\section{Effect of Size or C/S area on performance of the beams}

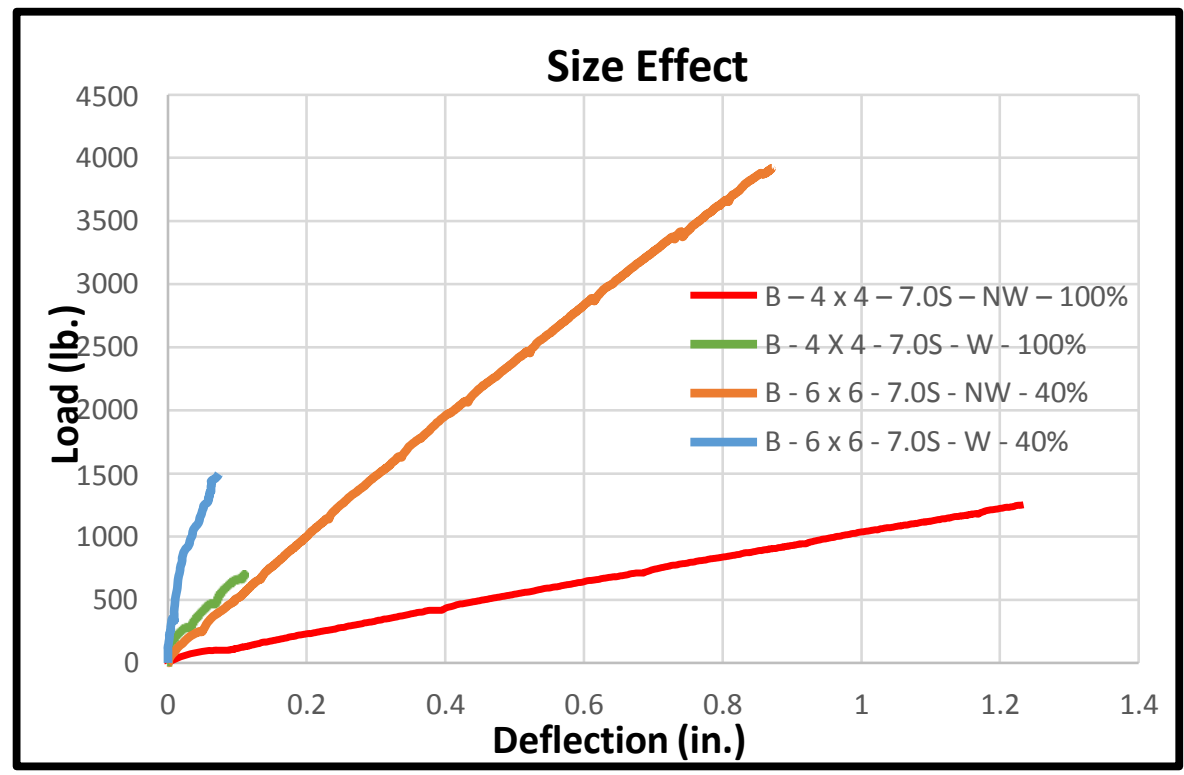


Here, we try to determine the effect of dimension change on stiffness of beams if any. Considering $\mathrm{B}-6 \times 6-7.0 \mathrm{~S}-\mathrm{W}-40 \%$ and $\mathrm{B}-4 \times 4-7.0 \mathrm{~S}-\mathrm{W}-100 \%$ specimens allows to keep the span and wrapped condition constant so that other comparisons can be made. Similarly, we also compare B - 6 × $6-7.0 \mathrm{~S}-\mathrm{NW}-40 \%$ and $\mathrm{B}-4 \times 4-7.0 \mathrm{~S}-\mathrm{NW}-100 \%$ to understand any size factor.

\begin{tabular}{|c|c|c|}
\hline Specimen & $\begin{array}{c}\text { Stiffness } \\
\text { (lbs./in.) }\end{array}$ & \multirow{2}{*}{ Percentage (\%) change } \\
\hline B $-6 \times 6-7.0 \mathrm{~S}-\mathrm{W}-40 \%$ & & \\
\hline $\mathrm{B}-4 \times 4-7.0 \mathrm{~S}-\mathrm{W}-100 \%$ & & \\
\cline { 1 - 2 } $\mathrm{B}-6 \times 6-7.0 \mathrm{~S}-\mathrm{NW}-40 \%$ & & \\
\cline { 1 - 2 } $\mathrm{B}-4 \times 4-7.0 \mathrm{~S}-\mathrm{NW}-$ & & \\
$100 \%$ & & \\
\hline
\end{tabular}

From the percentage changes, $\mathrm{B}-6 \times 6$ has an edge over $4 \times 4$ when it comes to performance with varying cross sections. B - 6 × 6 exhibits $352 \%$ increase in stiffness with respect to B - 4 x 4 beam maintaining constant span and reinforcement conditions. It can be concluded that irrespective of reinforcement, timber beams exhibit higher level of stiffness with increase of size/ cross-sectional dimensions.

Theoretically from the bending stress equation, as the cross-section increases, Moment of Inertia increases, which increases moment capacity as they are directly proportional. Here in our case the span can be constant hence the only parameter is load that must increase proportionally. Thus, cross-sectional change has effect on the stiffness of sample. 


\subsection{Analytical Models for strength of timber}

Maximum capacity of various sized timber samples

Theoretical calculations in determining the ultimate load carrying capacity of various species are performed and tabulated below. NDS manual has various design values for timber species, but are factored down by some safety number. These values are very much reliable but it's preferable to use the actual values without any factor of safety as we intend to find actual capacities theoretically. These values are obtained from FPL (Forest Product Laboratory) handbook.

The maximum load that could be applied in four point bending before failure is obtained by carefully maneuvering the basic equation of Theory of Simple Bending.

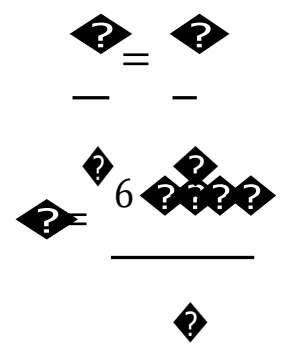

Sample calculations:

Select southern yellow pine with dimensions of 2.0" $\mathrm{x} 12.0$ ".

Bending strength of the sample from NDS is 975 psi

Bending strength from FPL handbook without any design safety reduction factors is $34000 \mathrm{kPa}$

Length of the sample is 8.0' and span is 7.0'.

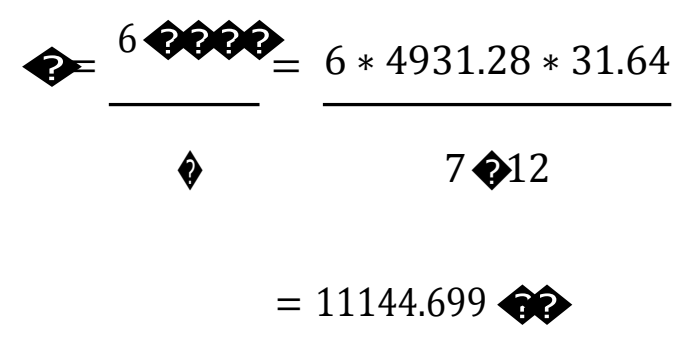

Southern Yellow pine: SP 
Douglas Fir-Larch - DF

\begin{tabular}{|c|c|c|c|c|c|c|}
\hline $\begin{array}{l}\text { Sampl } \\
\mathrm{e}\end{array}$ & $\begin{array}{l}\text { Lumber/Timber } \\
\text { Species } \\
\text { Single Board }\end{array}$ & $\begin{array}{c}\text { Length/Spa } \\
\mathrm{n} \\
(\mathrm{ft})\end{array}$ & $\begin{array}{c}\text { Cross- } \\
\text { Sectional } \\
\text { Dimensions } \\
\text { (in.) }\end{array}$ & $\begin{array}{l}\text { Design } \\
\text { bending } \\
\text { from NDS } \\
\text { (psi) }\end{array}$ & $\begin{array}{c}\text { Actual } \\
\text { bending } \\
\text { FPL } \\
\text { handbook } \\
(\mathrm{kPa} / \mathrm{psi})\end{array}$ & $\begin{array}{l}\text { Ultimat } \\
\text { e Load } \\
\text { (lb.)for } \\
\text { single } \\
\text { board }\end{array}$ \\
\hline 1 & $\mathrm{SF}$ & $16.0 / 7.0$ & $\begin{array}{l}2.0 " \mathrm{x} \\
12.0 "\end{array}$ & 975 & $\begin{array}{c}34,000 / 4931 . \\
2\end{array}$ & 11145 \\
\hline 2 & $\mathrm{SF}$ & $12.0 / 7.0$ & $\begin{array}{l}2.0 " x \\
10.0 "\end{array}$ & 1050 & $\begin{array}{c}34,000 / 4931 . \\
2\end{array}$ & 7534 \\
\hline 4 & SF & $12.0 / 7.0$ & $6.0 " x$ 6.0" & 850 & $\begin{array}{c}34,000 / 4931 . \\
2\end{array}$ & 9767 \\
\hline 5 & $\mathrm{DF}$ & $8.0 / 7.0$ & $4.0 "$ x 4.0" & 900 & $\begin{array}{c}47000 / 6816 . \\
7\end{array}$ & 3479 \\
\hline
\end{tabular}

\section{NDS Vs FPL}

\begin{tabular}{|c|c|c|c|c|c|c|}
\hline Description & Species & L/d & $\begin{array}{c}\text { FPL } \\
\text { Comp } \\
\text { Stress }\end{array}$ & $\begin{array}{l}\text { FPL } \\
\text { Max } \\
\text { Capacit } \\
\mathbf{y}\end{array}$ & $\begin{array}{c}\text { NDS } \\
\text { Comp } \\
\text { Stress }\end{array}$ & $\begin{array}{l}\text { NDS } \\
\text { Max } \\
\text { Capacity }\end{array}$ \\
\hline & & & (psi) & (kip) & (psi) & (kip) \\
\hline $\begin{array}{c}\mathrm{B}-2 \times 10-7.0 \mathrm{~S} \\
-\mathrm{NW}\end{array}$ & SP & 9.08 & 4931.283 & 7.534 & 1050.0 & 1.604 \\
\hline $\begin{array}{l}\mathrm{B}-2 \times 10- \\
11.0 \mathrm{~S}-\mathrm{NW}\end{array}$ & SP & 14.30 & 4931.283 & 4.794 & 1050.0 & 1.020 \\
\hline $\begin{array}{c}\mathrm{B}-2 \times 10-7.0 \mathrm{~S} \\
-\mathrm{NW}-2 \mathrm{G}\end{array}$ & SP & 9.08 & 4931.283 & 15.068 & 1050.0 & 3.208 \\
\hline $\begin{array}{c}\mathrm{B}-2 \times 10-\mathrm{NW} \\
-11.0 \mathrm{~S}-2 \mathrm{G}\end{array}$ & SP & 14.30 & 4931.283 & 9.588 & 1050.0 & 2041.77 \\
\hline $\begin{array}{c}\mathrm{B}-2 \times 10-7.0 \mathrm{~S} \\
-\mathrm{NW}-3 \mathrm{G}\end{array}$ & SP & 9.08 & 4931.283 & 22.602 & 1050.0 & 4.812 \\
\hline $\begin{array}{c}\mathrm{B}-2 \times 10-\mathrm{NW} \\
-11.0 \mathrm{~S}-3 \mathrm{G}\end{array}$ & SP & 14.30 & 4931.283 & 14.382 & 1050.0 & 3.062 \\
\hline $\begin{array}{c}\mathrm{B}-2 \times 12-7.0 \mathrm{~S} \\
-\mathrm{NW}-2 \mathrm{G}\end{array}$ & SP & 7.47 & 4931.283 & 22.28 & 975.0 & 4.407 \\
\hline $\begin{array}{c}\mathrm{B}-2 \times 12-9.0 \mathrm{~S} \\
-\mathrm{NW}-2 \mathrm{G}\end{array}$ & SP & 9.60 & 4931.283 & 17.376 & 975.0 & 3.427 \\
\hline
\end{tabular}




\begin{tabular}{|c|c|c|c|c|c|c|}
\hline $\begin{array}{c}\text { B }-2 \times 12- \\
11.0 \mathrm{~S}-\mathrm{NW}-2 \mathrm{G}\end{array}$ & SP & 11.74 & 4931.283 & 14.178 & 975.0 & 2.804 \\
\hline $\begin{array}{c}\mathrm{B}-6 \times 6-7.0 \mathrm{~S} \\
-\mathrm{NW}-\end{array}$ & SP & 15.30 & 4931.283 & 9.767 & 850.0 & 1.683 \\
\hline $\begin{array}{c}\text { B }-6 \times 6-11.0 \mathrm{~S} \\
-\mathrm{NW}\end{array}$ & SP & 24.0 & 4931.283 & 6.215 & 850.0 & 1.071 \\
\hline $\begin{array}{c}\mathrm{B}-4 \times 4-5.0 \mathrm{~S} \\
-\mathrm{NW}\end{array}$ & DF & 17.10 & 6816.777 & 4.871 & 900.0 & 0.643 \\
\hline $\begin{array}{c}\mathrm{B}-4 \times 4-7.0 \mathrm{~S} \\
-\mathrm{NW}\end{array}$ & DF & 24.0 & 6816.777 & 3.479 & 900.0 & 0.459 \\
\hline
\end{tabular}

\section{Deflection Calculations:}

Theoretical Deflection $\Delta=$

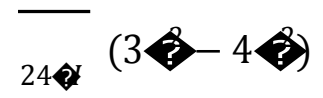

Serviceability limits $=\mathrm{L} / 200$ to $\mathrm{L} / 400$

Determining the capacity and strengths of timber beams strengthened with FRP in the tension region

Strengthening of timber structures with Fiber reinforced polymers (FRP) strips is a solution which is based on analogous, commonly used strengthening of RC-structures [1]. There are number of previously determined set of equations in case of RC structures but for timber ones there are very few from the past that can be recollected.

The equivalent ratio of the tension modulus of elasticity of FRP to the modulus of elasticity of timber along the grains under axial compression:

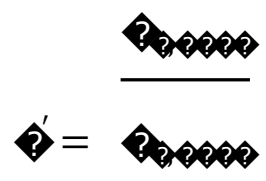

Usually $=1$ for simplicity 
The equivalent ratio of the tension modulus of elasticity of FRP to the modulus of elasticity of timber along the grains under axial compression:

Where:

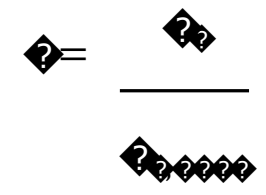

Mean modulus of elasticity of timber under tension along the grains.

Mean modulus of elasticity of timber under compression along the grains.

= Modulus of elasticity of the FRP strip under tension.

The depth of neutral axis after FRP strip is attached in the tension zone is;

Where:

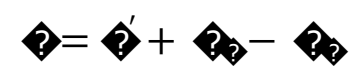

Neutral axis depth from top compression zone for unstrengthen beam is given by:

$$
?=h \frac{\sqrt{?}}{1+\sqrt{?}}
$$

The below two equations are related to FRP in the tension zone and are responsible for the modified neutral axis to reduce the area in the tension region and allow for a compression failure.

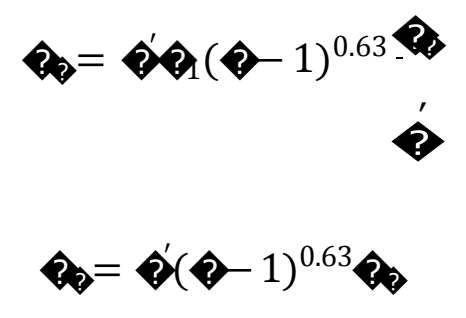

$h=$ depth of beam,

P $=$ total thickness of FRP strip in tensional zone, 
=xternal timber layer

= distance from the centerline of FRP strip to the edge of the beam.

In our case there is no additional timber strip attached to the FRP in tension zone, so the above equations get slightly modifies;

Q

Thus neutral axis depth turns down to

Evaluation of neutral axis depth is continued by determination of moment of Inertia,

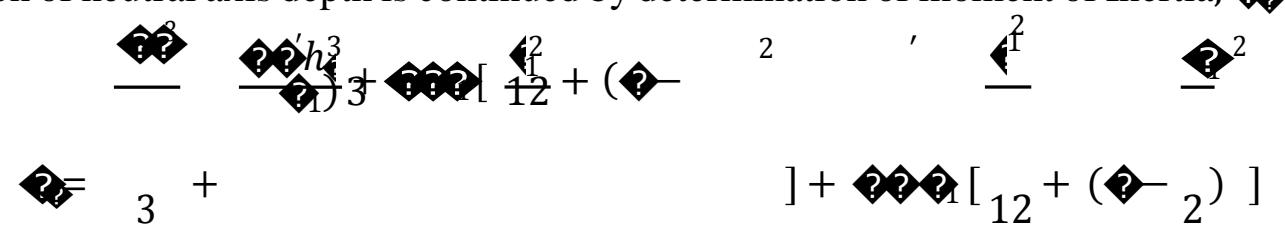

The allowable bending moment for reinforced cross-section is given by

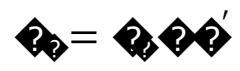

Where
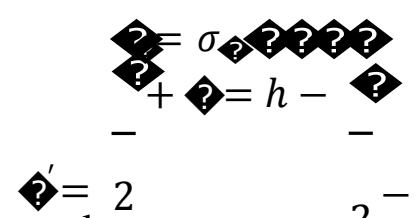

Axial tensile stress in FRP strip is equal to:
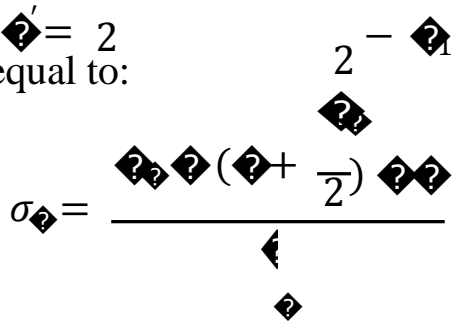

A different approach is chosen in determining the moment of inertia which is called equivalent area method. For bema strengthened using CFRP plate, the plate is transformed into equivalent timber section. 
The equivalent timber area is determined from

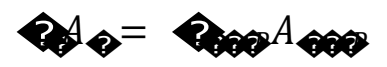

New width is determined from equivalent timber area:

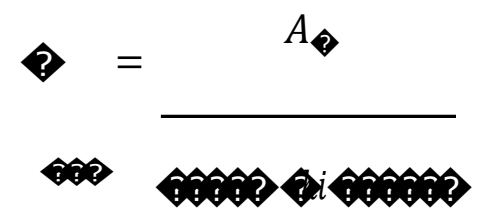

The neutral axis depth and moment of inertia for the new equivalent section are determined. 


\section{Chapter 7. Timber Bridge Design with Steel Girders}

\subsection{Introduction}

Timber bridges are a sight of aesthetic pleasure, their durability, and most importantly cost effectiveness gives it an edge over other bridge materials. The availability of the material is also a key considerable factor, as timber being a natural material that is readily available most of the times. Pedestrian bridges also called as Foot Bridge or over pass-bridge is essentially designed for pedestrians and occasionally includes cyclists, animal traffic, and horse riders.

This design includes following elements in a covered bridge (canopy): Timber deck, Steel girders,

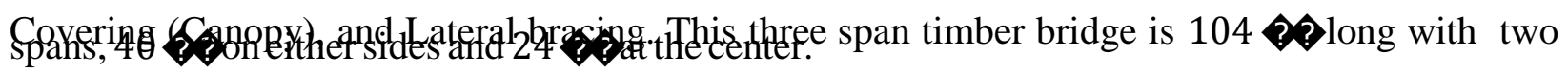

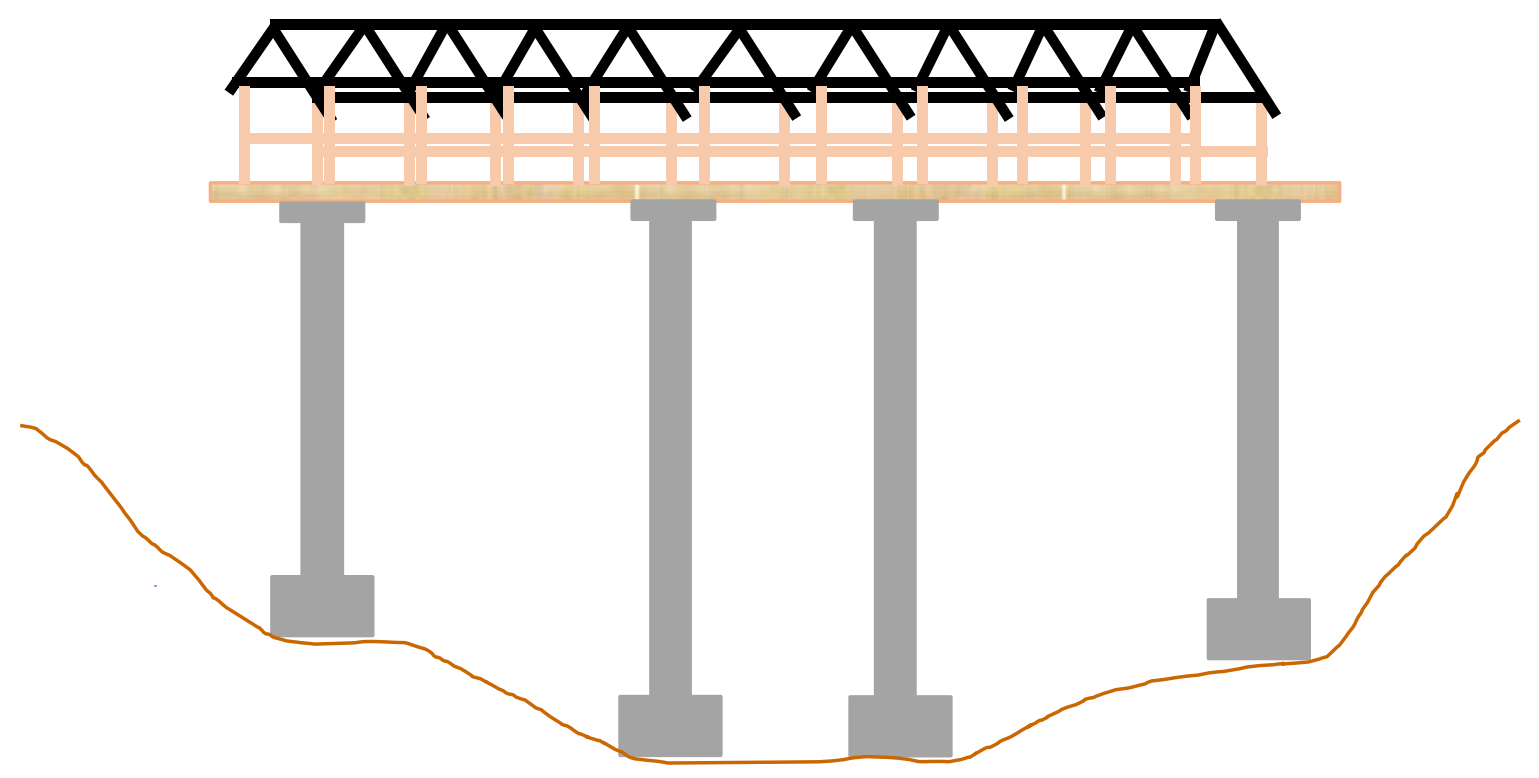

Figure 7.1: View of the Timber Pedestrian Bridge 


\subsection{Design Problem}

Total length of the bridge $=104$

It has three spans wherein; center span comprises of 24 and the end spans are of 40 ach in length

\subsubsection{Specification(s)}

1. AASHTO LRFD 2012 Bridge design specifications

2. Timber Bridge design construction manual

3. LRFD Bridge design procedure for timber

4. Timber construction manual

5. Steel construction manual ( $14^{\text {th }}$ edition $)$

\subsubsection{Materials}

Structurnthsteeli AAASHTQMM270 270 Grade HPS 50W (minimum tensile strength = 70 ASTM: A709/A 709M Grade HPS 50W

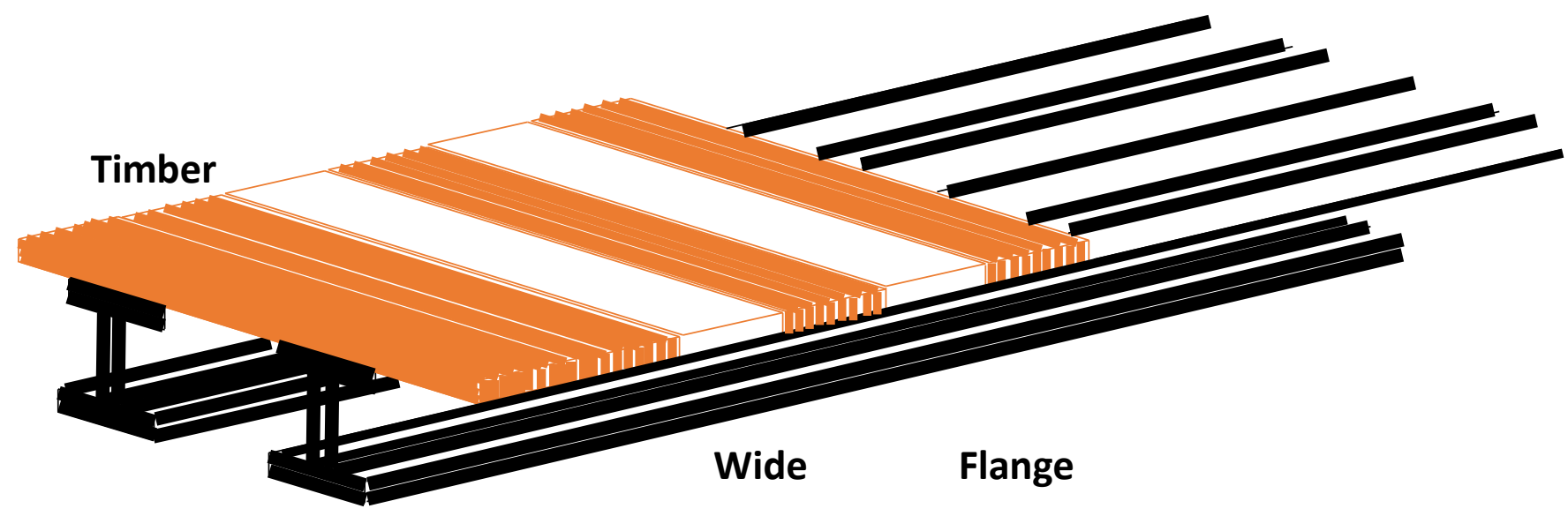

Figure 6.2: Isometric view of steel stringers with Timber Decking 


\subsubsection{Design Considerations for $p$ Span Deck}

Width of the deck (4 people be able to walk at the same time) $=10.0$

We provide three longitudinal Wide Flange Girder beams or stringers along the length in all the three spans.

Girder depth: overall depth of composite W-beam

Depth of I-portion

When trusses are provided (AASHTO Table 2.5.2.6.31)

Depth now is

Also depth of complete beam is

$$
\begin{aligned}
& = \\
& =0.027 * 032 * \\
& =0.1 * \\
& =0.027 * ?=0.027 * 40 \\
& =1.08 ? \\
& =0.032 * ?=0.032 * 40 ? \\
& =1.28 ?=15.36 i
\end{aligned}
$$

The minimum depth that has to be provided must be higher than the above obtained value, So let's assume a depth of $\gg \mathrm{in}$. overall.

\section{Cross-section properties}

Orthotropic deck should never be less than 0.25

\section{From AASHTO}

Web without longitudinal stiffeners $=\mathrm{D} / \mathrm{t}_{\mathrm{w}} \leq 150$

AASHTO (6.10.2.1.1-1)

Web with longitudinal stiffeners $\quad=\mathrm{D} / \mathrm{t}_{\mathrm{w}} \leq 300$

AASHTO (6.10.2.1.2-1)

\section{Web and Flange Dimensions:}

\section{Flange proportions}

$$
\text { P. }(2 *) \leq 12.0
$$

AASHTO (6.10.2.2-1)

$\geq 20$

AASHTO (6.10.2.2-2)

$\geq 1.1 *$ (This criteria resists shear buckling of web by flange)

AASHTO (6.10.2.2-3)

$0.1 \leq(2) \leq 10$

AASHTO (6.10.2.2-4)

Where ${ }_{\mathrm{yc}}=$ Moment of Inertia of compression flange about vertical axis

$\theta_{\mathrm{t}}=$ Moment of Inertia of tension flange about vertical axis

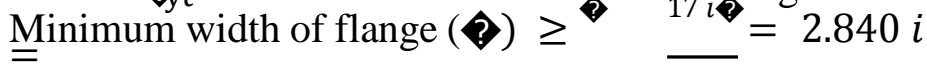


So, $\geq 2.840 i$ and we assume it to be $6.0 i ?$ 
$\geq 1.1 * 2.1 * 0.5=0.561 i$

AASHTO guidelines recommend a minimum thickness of $0.750 i$

Top flange width is assumed slightly higher than the minimum to resist flange lateral bending, due to eccentric loading, wind loads, in the region of positive shear.

We also have to validate other few checks before finalizing the dimensions.

Web proportions

Without Yongitudinal stiffeners:

아수 $\leq 150$ So, $=0.113 i$

According to AASHTO/NSBA steel bridge collaborations guide lines for Design for constructability recommends minimum web thickness of $0.437 i$ and preferred $0.50 i$.

Note: Bottom flange sizes in regions of negative flexure are controlled by either flange local buckling or lateral torsional buckling resistance at the strength limit state. Top flange sizes in these regions are assumed controlled by tension flange yielding at the strength limit state.

\title{
7.3 Load Combinations
}

\author{
Strength $1: 1.25 * 2 ?+1.5 * ?+1.75 * ?$

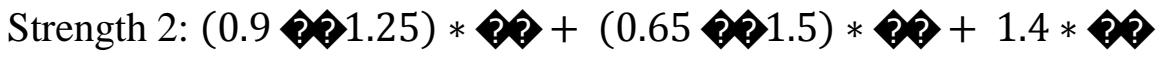

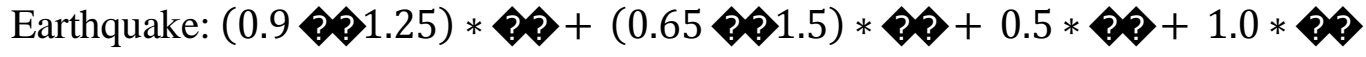 \\ Fatigue: $1.5 *(? ?+? ?+? ?)$ \\ Where $\mathrm{DC}=$ Dead load from structure \\ DW $=$ Dead load from wear surface \\ $\mathrm{LL}=$ Vehicular live load \\ $\mathrm{WS}=$ Wind load on structure \\ $\mathrm{EQ}=$ Earthquake load \\ $\mathrm{IM}=$ Vehicular dynamic load allowance \\ $\mathrm{CE}=$ Vehicular centrifugal force
}

\section{Loads:}

Unit weight for various materials used in bridge construction:

Timber =50 ?? 


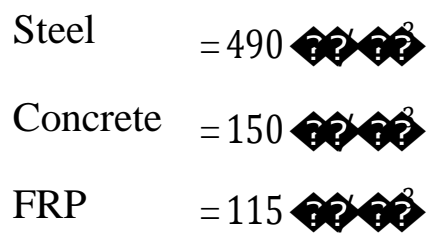

\subsection{Various Dead Loads}

\subsubsection{Timber Deck}
According to code specifications, thickness of $=4.0 i$ for roadways
deck
$=2.0 i$ for sidewalks for plank wood
$=6.0 i$ other than planks
Width of the wooden deck
$=10.0 \gg=120.0 i$
Deck weight

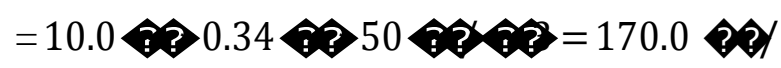
Railing over the deck

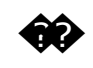
$=45$ ?

Deck dead load and moment:

Deck, $\mathrm{W}_{\mathrm{DL}}$

$$
\begin{aligned}
& =170.0+45.0 \\
& =215.0
\end{aligned}
$$

Bending Moment for deck, $\mathrm{M}_{\mathrm{DL}}$

$$
=\frac{215 * 40 * 40}{8}
$$

$=42 \cap \Omega \Delta S$

Self-weight $=($ Area of the of the flange + area of the web $) *$ unit-weight of member

$$
\begin{array}{cc}
= & (0.5 *(17-1.5)+(2.0 * 0.75 * 6.0)) * 490 \\
=56.996 & = \\
& =56.996 * 40 * 40
\end{array}
$$

Bending moment, $\mathrm{M}_{\mathrm{DL}}$ 
Dead load of wear surface, internal girder, $=$ W DW

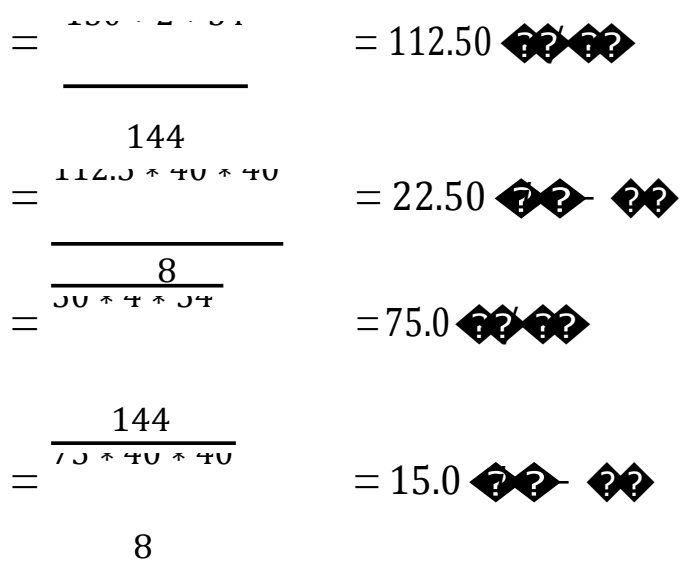

\subsubsection{Lane Load Distribution Factor}

For longitudinal beams: for one traffic lane

$=$ Glulam $=$ P $10.0=4.5 / 10=0.450$

$=$ Timber plank $=$ ? $6.7=4.5 / 6.7=0.671$

Transverse beam: Distribution factor

$$
\begin{aligned}
& =\text { Glulam }=? / 5 \\
& =\text { Timber }=? / 4
\end{aligned}
$$

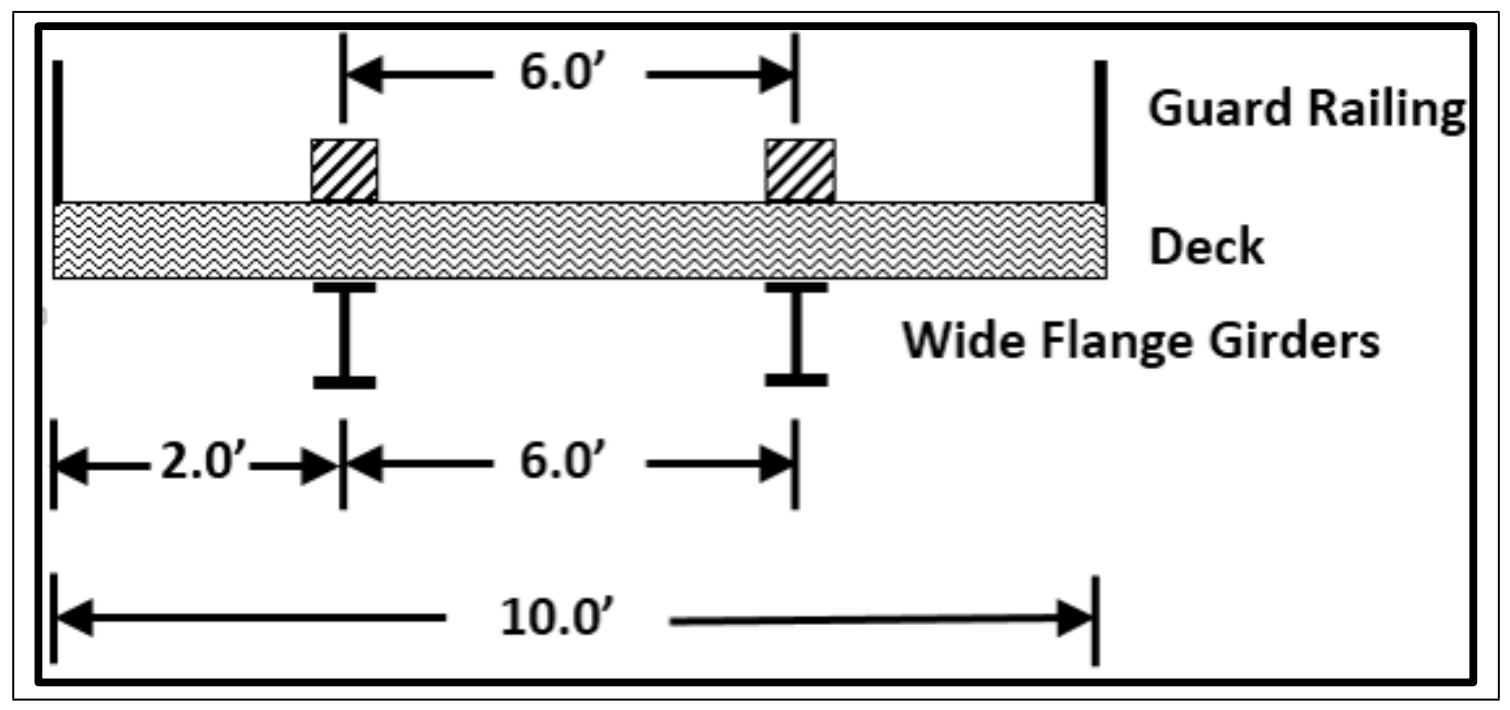

Figure 6.3: C/S of pedestrian bridge showing LRFD distribution for exterior stringer 
Longitudinal beam or Stringer

Live load distribution factor, (Level Rule)

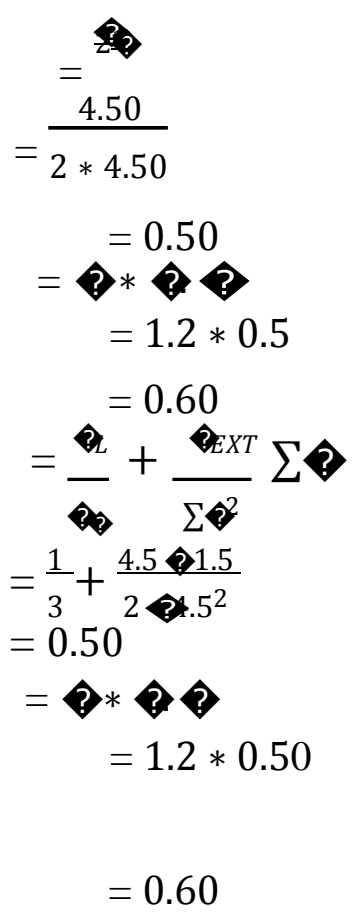

\section{Camber:}

Glulam bridge girders are cambered for appearance and drainage. AASHTO LRFD specifies glulam girders be cambered a minimum of two times dead load deflection at the service limit state. Stress laminated timber bridge deck must be cambered for three times the dead load deflection at the service limit state.

\section{Collision mitigation:}

AASHTO LRFD 2.3.3.2 vertical clearance specifies the vertical clearance from the roadway to the overhead cross bracing of through-truss structures should not be less than $17.5 \mathrm{ft}$. The vertical clearance for sign supports and pedestrian overpass should be $1.0 \mathrm{ft}$. greater than the highway structure clearance. Reductions in vertical clearance, due to settlement of an overpass structure shall be investigated and if any expected settlement exceeds $1.0 \mathrm{in}$. it shall be added to the specified clearance. Other ways to mitigate the risk from vehicle collision are providing structural continuity 
of super structure either between spans or with the substructure, increasing mass of the superstructure, increasing lateral resistance of the super structure. Out of all the alternatives, increasing vertical clearance is a pronounced practice in real time scenarios.

\subsubsection{Vehicular Live Load}

Pedestrian bridges, the name itself defines its exclusivity for pedestrians but are designed for a maintenance vehicle load and Strength 1 Combination $(1.75 *$ LL or IM or CE or BR or PL or $\mathrm{LS}+1.0 * \mathrm{WA}+1.0 * \mathrm{FR})$ unless otherwise specified by the owner. Depending upon the requirements of the client a single truck shall be placed to produce the maximum load effect and shall not be placed in combination with pedestrian load.

\begin{tabular}{|l|l|}
\hline $\begin{array}{l}\text { Design } \\
\text { Vehicle }\end{array}$ & $\begin{array}{l}\text { Clear deck } \\
\text { width }\end{array}$ \\
\hline H5 & $7.0-10.0 \mathrm{ft}$. \\
\hline H10 & Over10.0ft. \\
\hline
\end{tabular}

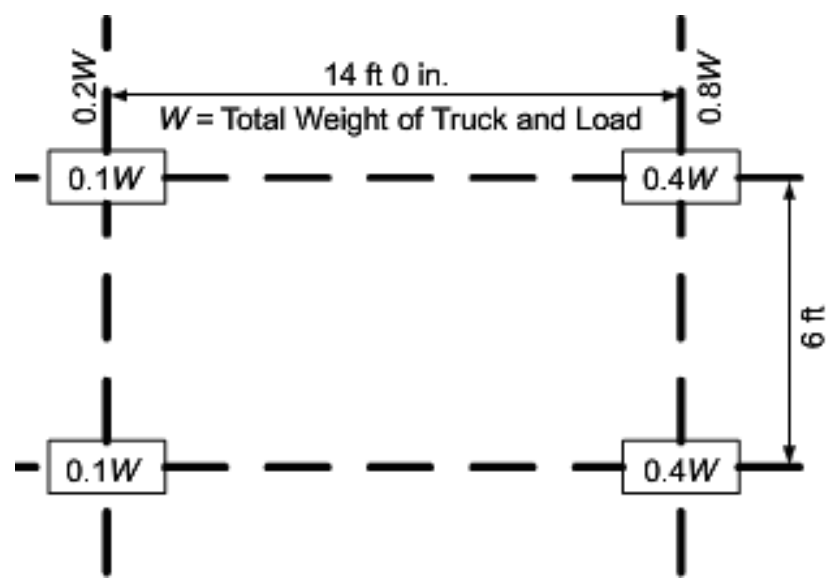

Figure 6.4: Design vehicle with clear span and their wheel load distribution

For H5 vehicle

Live load distribution factor (DF)

$$
\begin{aligned}
& =10000 \\
& =\frac{\nabla}{10}=\frac{4.5}{10}=0.45
\end{aligned}
$$

Live load distribution factor exterior girder, level rule $=$ There are different possible scenarios of positioning of wheel loads on the deck and are explained in LRFD Bridge design Chapter 
Live load distribution on the girder one-lane loaded:

Front axle

Rear axle

Uniform lane load

Concentrated load for moment

Concentrated load for shear

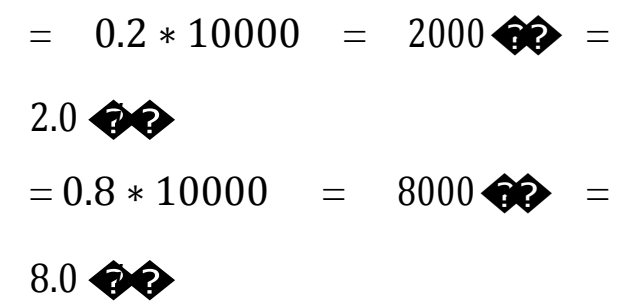

$=0.016 *$ ?? $=0.016 * 10000$

$=160.0$

$=0.45 * ? 2 ?=4500 ? ?=$

4.50

$=0.65 *$ ??? $=6500$ ??

$=$

\subsection{0}

When vehicular load acts as a point load, the maximum bending moment occurs under the maximum load when the resultant of all the loads and the maximum load act at equal distances on either sides from the center.

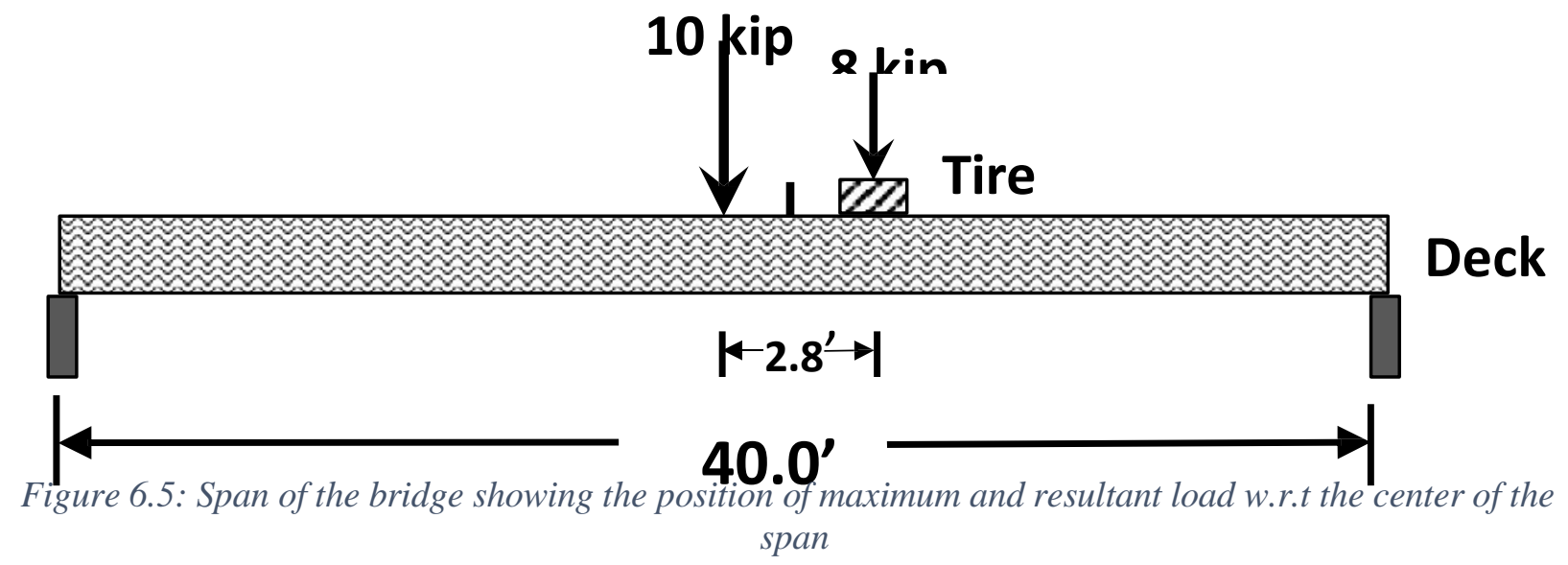

Distance of maximum load from the resultant of all the loads to generate maximum bending moment is, 


$$
\begin{aligned}
\mathrm{x} & =\frac{2000 * 14}{10000} \\
& =2.8 i
\end{aligned}
$$$$
\text { Maximum moment }
$$

\section{Lane Loading:}
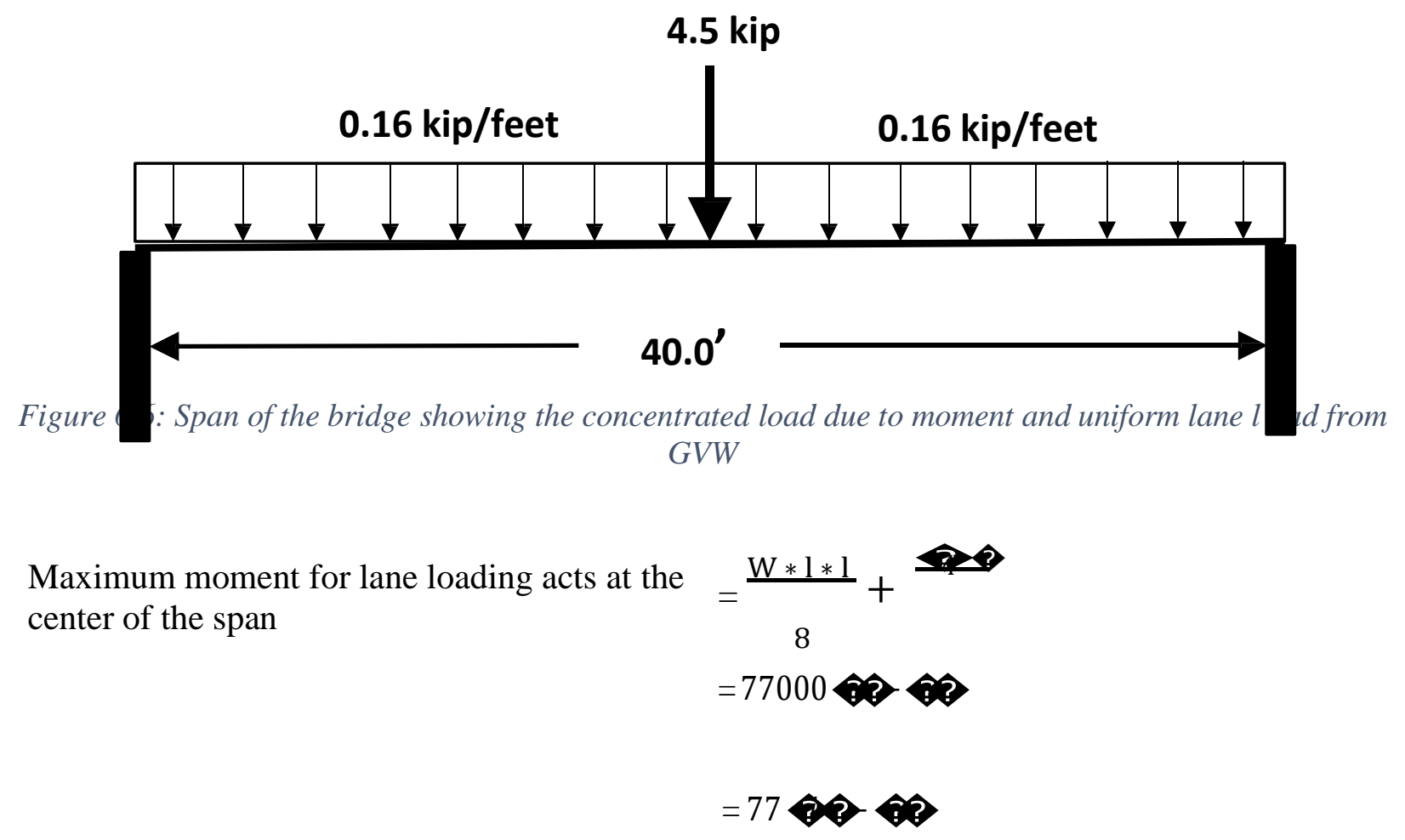

\subsubsection{Pedestrian Load}

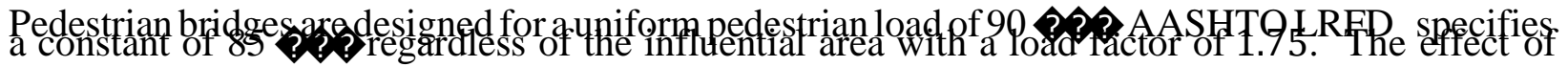
dynamic load is not necessary to be included in here; 
Pedestrian load

Factor

So factored load

Converting pedestrian load over the area to a line load

Moment due to load

$$
=85.0 \text { ?? }
$$

$=1.750$

$$
=1.75 * 85=149.0
$$

$$
\begin{aligned}
& =149 * 10=1490.0 \\
& =\frac{\nabla}{8} \\
& =298.0 ? ?
\end{aligned}
$$

\subsubsection{Equestrian Load}

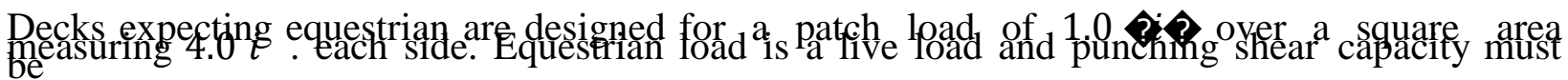
ensured as horses are expected on the bridges. Heavy load from equestrians are transferred to the deck during trot, canter and gallop. Among all, Canter has worst effect on the deck, where the loading on one hoof approaches hundred percent of the total weight of the horse (AASHTO, LRFD

Bridge design specification for pedestrian bridges, 2009). A total factored load of 1.75 approximately the maximum credible weight of a draft horse (Elizabeth S. Roland., 2005). A deck must be able to support at least 1.7 times body weight or $9000 ?$ with a 550 ? horse which is the representative force applied to the legs during high performance activity (Kings HB., 1978 )

ScRFP gyidg specifications for the design of pedestrian bridges specifies 1 ?

Factored load

Area covered by hoop

Equestrian load per unit length

$$
\begin{aligned}
& =1.75 \text { = }=1750 \\
& =4.0 i . * 4.0 i .=16.0 \text { ใ? } i \\
& =1.10=1.3125 \text { Pे? } / \text { ?? }
\end{aligned}
$$

$(16 / 12)$ 
The worst loading occurs during a canter where the loading on one hoof approaches $100 \%$ of the total weight of the horse.

Maximum load onto the surface through the hoof occurs when the horse canters, which would be the whole body weight would be transferred through one hoof $=9000 ?=2023.280 ? 2=$

\subsection{3 ?}

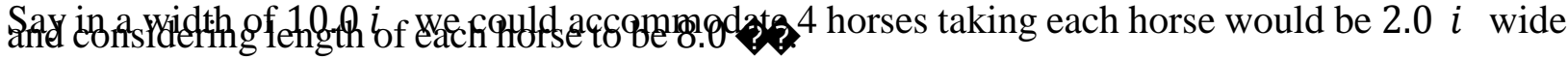

So, the total load that comes on to the deck

from all the horse

$$
=4 * 2.023=8.092 \text { ?े? }=8092
$$

Converting this into uniformly distributed load $=^{\text {v.u }}=1.0115$ ?

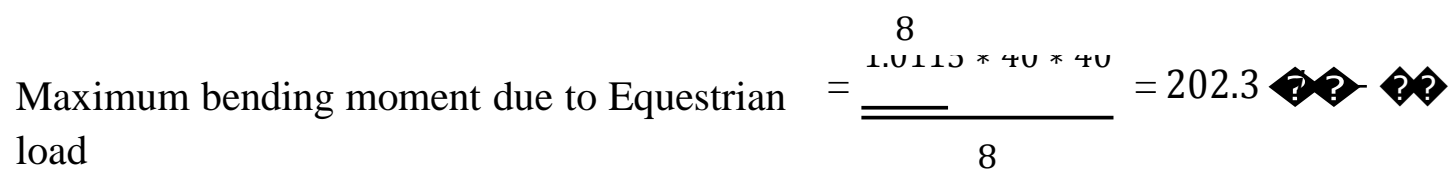

This value of bending moment is less than the maximum bending moment due to pedestrian load, so we need not take equestrian load into consideration.

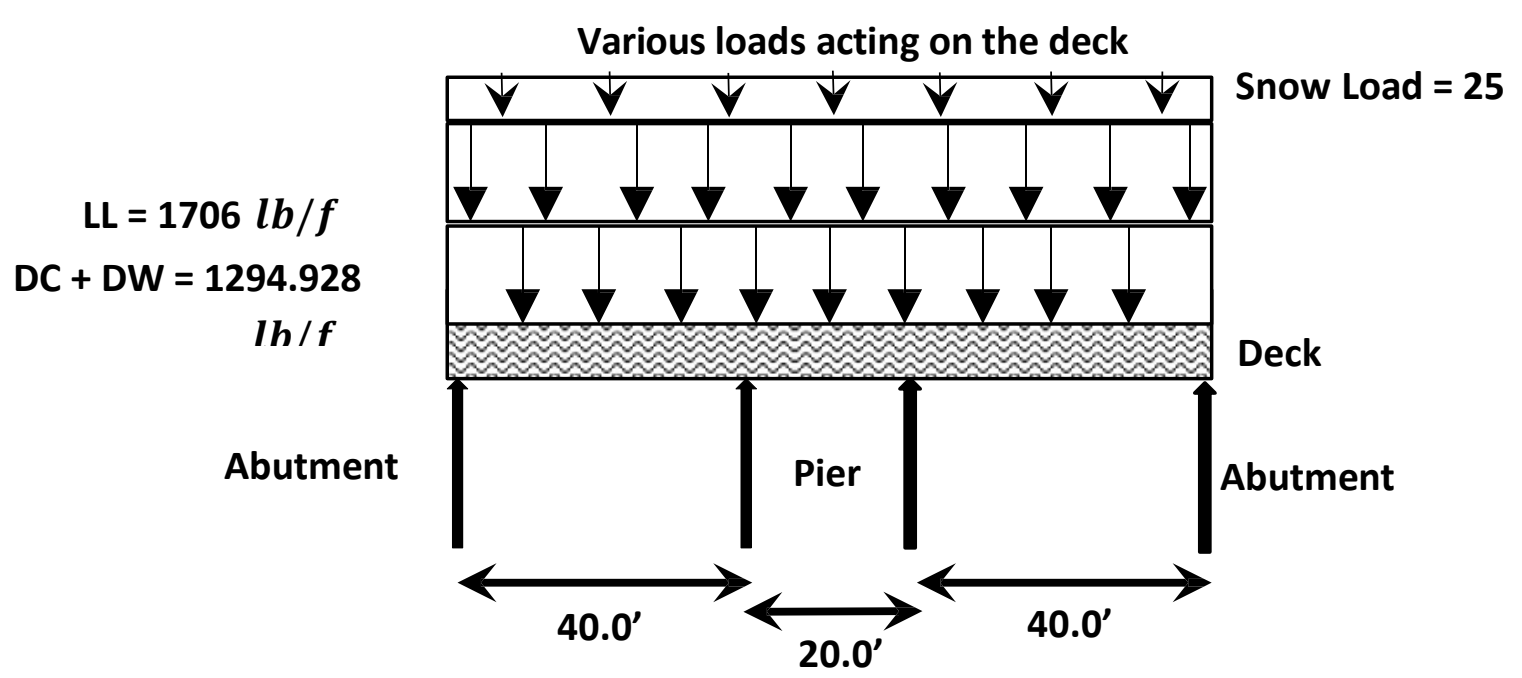

Figure 6.7: Detail description of various loads coming on to the deck over various spans

\section{Check for Punching Shear}

Stress developed in the deck due to hoop load $=$ from horse

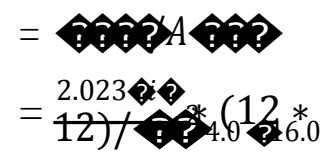




$$
\begin{aligned}
& =4.551 \\
& =31.604
\end{aligned}
$$

Taking visually graded Dimension lumber, Structural Douglas Fir Larch type of dimensions $3 i$

Shear stress of the wooden plank $=625$

Adjusted compression perpendicular to grain

$$
\begin{aligned}
=(2) & *(2) \\
= & 625 * 1.0 * 1.0 * 1.0 \\
= & 625
\end{aligned}
$$

From above stress perpendicular to the grain direction > hoof stress from the equestrian load

\begin{tabular}{|c|c|c|c|c|}
\hline Element considered & Factor & $\begin{array}{c}\text { Load } \\
\text { Distribution } \\
\text { (lb/ft.) }\end{array}$ & $\begin{array}{c}\text { Factored } \\
\text { Load } \\
\text { (lb/fit.) }\end{array}$ & $\begin{array}{c}\text { Cumulative } \\
\text { Load } \\
\text { (lb/ft.) }\end{array}$ \\
\hline Deck weight & - & - & 170.0 & \\
\hline Railing over the deck & - & - & 45.0 & 215 \\
\hline $\begin{array}{c}\text { Self-weight of the deck (from the assumed } \\
\text { dimensions) }\end{array}$ & - & - & 57.0 & 272 \\
\hline Dead load of wear surface, & - & & 112.5 & 384.5 \\
\hline Dead load of deck based on tributary width & - & & 75.0 & 459.5 \\
\hline Uniform lane load & - & & 160.0 & 619.5 \\
\hline Pedestrian load & 1.75 & 850 & 1490.0 & 2109.5 \\
\hline Equestrian load & 1.70 & 595 & 1011.5 & 3121.0 \\
\hline $\begin{array}{l}\text { Total load per unit length (includes dead } \\
\text { and live load) }\end{array}$ & - & & & 3121.0 \\
\hline
\end{tabular}
So the timber species taken for deck are safe in punching shear.

\section{Summary of loads:}

Total load of $3.121 \mathrm{kip} / \mathrm{ft}$. is being transferred from all the dead and live loads on to the deck

Table 6.1: Summary of Loads 


\subsubsection{Snow Loads}

Structures in areas of heavy snow and ice throughout winter must be designed to sustain snow loads along with others. Most Eastern, North-eastern states like West Virginia, Massachusetts, Pennsylvania, and Michigan design their structures for extreme snow loads with great preciseness and importance as they experience heavy snow storms all-round the season.

The accumulation of heaps of ice while snow fall on the deck would cause a sudden increase of load which might stay undisturbed for several days in rural areas where pedestrian traffic movement would be less. So the design of bridge would account for all these scenarios (AASHTO, LRFD Bridge Design Specifications, 2012) (Section 3.9).

Add about half the load that usually comes as this is a covered pedestrian bridge Snow load on the surface

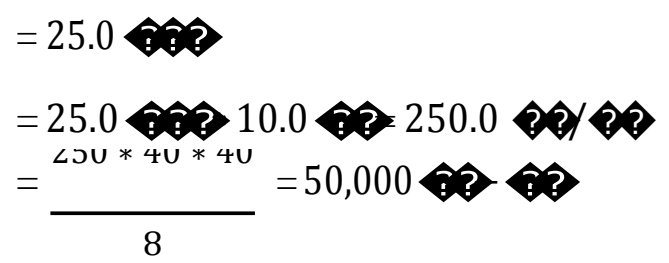

\subsubsection{Wind Loads}

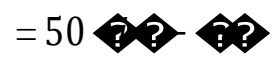

\subsubsection{Loads from Superstructure and Forces Applied to the Sub-Structure}

Wind here is not taken as normal to the structure, the base wind pressures, $\mathrm{P}_{\mathrm{B}}$ for various angles of wind direction may be taken as specified in Table 3.8.1.2.2.1 of AASHTO

- 0.05 transverse

- 0.012 longitudinal 
A vertical upward wind force of 0.020 ? sidewalks, shall be considered to be a longitudinal line load. This force shall be applied at the windward quarter point of the deck width.

Load on Exposed Super-Structure area

Load on Trusses and Arches

Exposed deck on wind ward side

Moment due to wind load on deck

Railing vertical

Moment

Take 12 vertical members

Railing horizontal

Moment

Take two rows of horizontal members

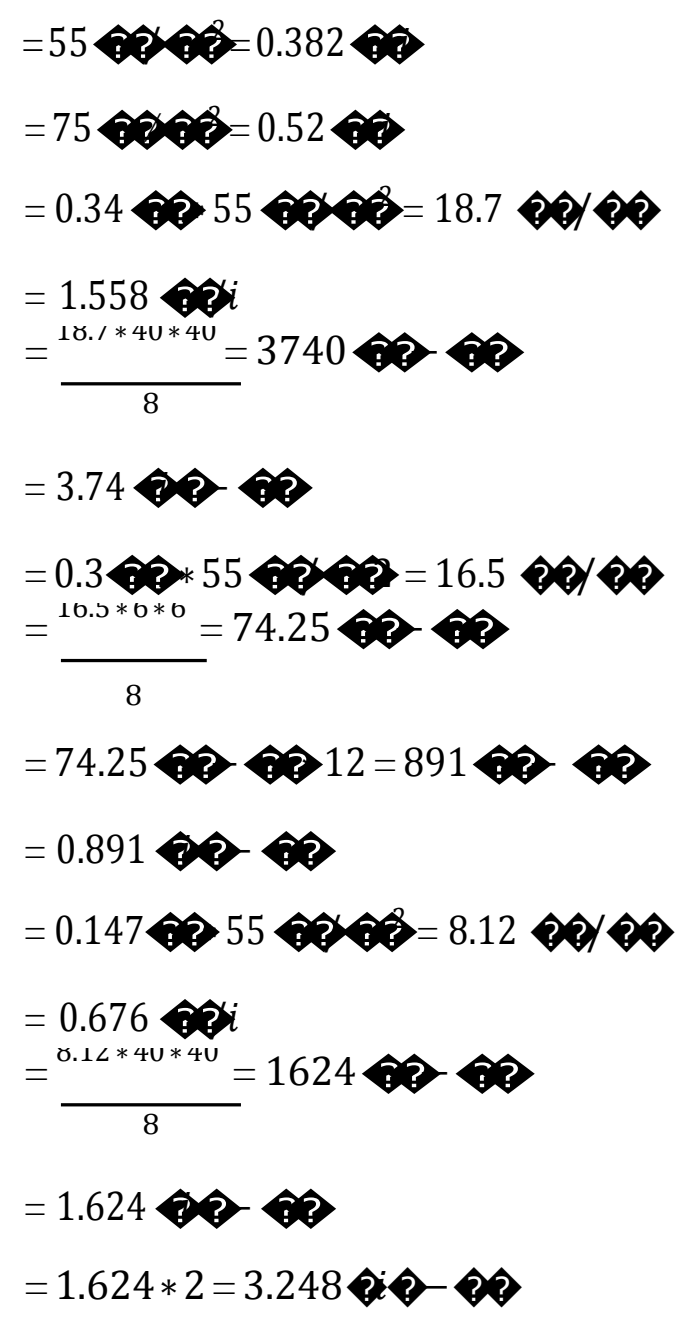

\subsubsection{Wind Pressure on Vehicles}

Wind pressure on vehicles shall be represented by an interruptible, moving force of 0.10

\section{Q2)}


acting normal to, and 6.0 above, the roadway and shall be transmitted to the structure. Wind 
acting at different angles have varying values of normal and parallel component are tabulated in Table 3.8.1.3-1.

Vehicle is 14.0 ? ?long

Wind load acting on the moving vehicle

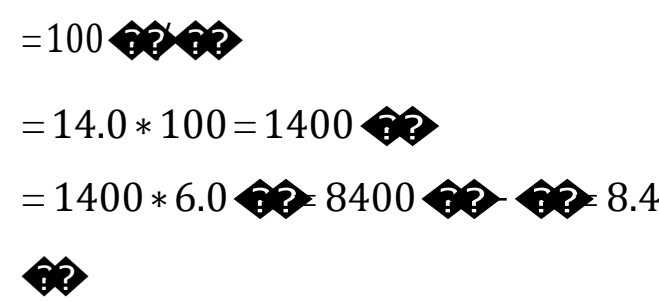

summent due to wind load acting at 6.0 ??

So total load acting on the $\$ 5$ vehicle is

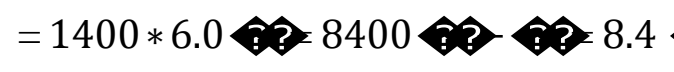

above the surface of the deck

Table 6.2: Summary of loads on to the bridge from snow and wind

\begin{tabular}{|c|c|c|c|c|}
\hline Element considered & Factor & $\begin{array}{c}\text { Load } \\
\text { Distribution } \\
(\mathbf{l b} / \mathbf{f t} .)\end{array}$ & $\begin{array}{c}\text { Factored } \\
\text { Load } \\
\text { Distribution } \\
\text { (lb/ft.) }\end{array}$ & $\begin{array}{c}\text { Total } \\
\text { Weight } \\
\text { (lb/ft.) }\end{array}$ \\
\hline Snow load per unit length & - & & 250.0 & \\
\hline Exposed deck on wind ward side & - & - & 18.7 & 268.7 \\
\hline Vertical railing & - & - & 16.5 & 285.2 \\
\hline Horizontal railing & - & - & 8.12 & 293.32 \\
\hline $\begin{array}{c}\text { Wind load acting on the moving } \\
\text { vehicle }\end{array}$ & - & - & 100 & 393.32 \\
\hline $\begin{array}{c}\text { Total load coming on to the deck } \\
\text { due to snow and wind }\end{array}$ & & & & $\mathbf{3 9 3 . 3 2}$ \\
\hline
\end{tabular}




\subsection{Design of Canopy}

\section{Loads to be considered from the surface:}

- Wind load

- Snow load

- Self-weight of the sheathing

\subsubsection{Calculating Wind Loads}

Basic design wind velocity $\mathrm{V}_{\mathrm{B}}$ is assumed to be $100 \mathrm{mph}$. Bridges or parts of bridges more than $30.0 \mathrm{ft}$. above low ground or water level, the design wind speed $\mathrm{V}_{\mathrm{DZ}}$ should be adjusted according to,

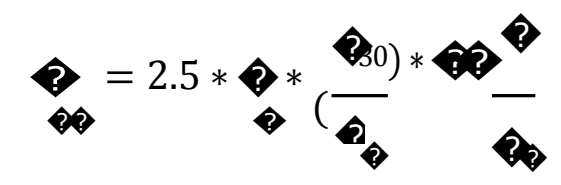

Wind pressure on the structure is determined by,

Where;

$\mathrm{V}_{\mathrm{B}}=100 ? ? \mathrm{~h}$

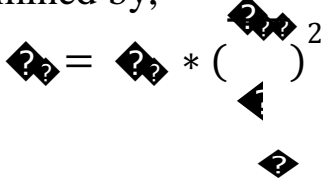

$\mathrm{P}_{\mathrm{B}}=$ Base wind pressure (??) Refer AASHTO (Table 3.8.1.2.1-1)

Spacing between two consecutive posts

$$
\begin{aligned}
& =10.0 \\
& =1 / 2 \\
& =P_{D}=P_{B} *\left(V_{D Z} / V_{B}\right)
\end{aligned}
$$

Horizontal wind pressure

Where,

$\mathrm{P}_{\mathrm{B}}=$ Base wind pressure (AASHTO 3.8.1.2)

$\mathrm{V}_{\mathrm{B}}=$ Base wind pressure $=100 ? \mathrm{~h}$

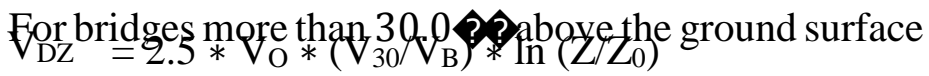

$$
\begin{aligned}
& =2.5 * 8.2 *(100 / 100) * \text { S? } 100 \text { ? } 0.23) \\
& =124.53 \text { ?? }
\end{aligned}
$$


$\mathrm{P}_{\mathrm{D}}=(0.05) *(\underline{124.53})^{2}=0.0775$

100

Force that is acting normal to the surface $=\mathrm{P}_{\mathrm{D}} *(26.565)$

of the roof (Windward)

$=34.658$

$=35.020 .243$

$\mathrm{P}_{\mathrm{D}}=0.025 *(124.53 / 100)^{2}=0.0387$

Force that is acting normal to the surface of the = roof (Leeward)

$=$

$=17.307$

\subsubsection{Wind and Snow Load on the Canopy}

Wind ward side pressure

Snow load on the surface

Wind load per unit length

Snow load per unit length

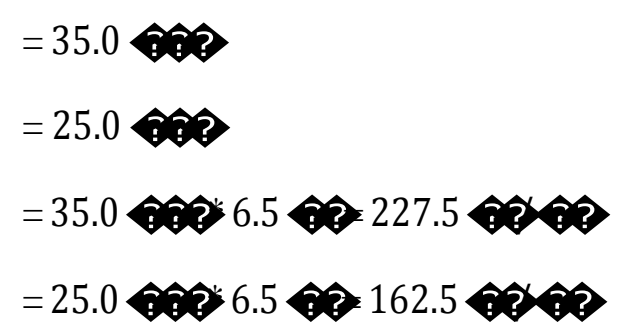

Total load on the surface or cover on windward side

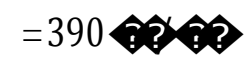

Leeward side pressure

$=17.307$. 0.194

Wind load per unit length

Snow load per unit length

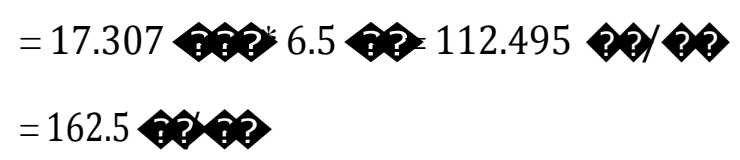

Total load on the surface or cover on leeward side

$$
=274.995 \text { ? }
$$

Take 390 fromboth windward and leeward side

So the total load per unit length

$$
=780 \text { ㅇ? }
$$




\subsubsection{Sheathing}

Southern pine structural species are considered

Dimensions

Density

Bending stress
$=12 i$ wide $*(2.0-4.0) i$ thick

$=52-53$

$=2050$

Compression perpendicular to direction of the grain

$$
=660
$$

Now we are designing for a length of 10.0 (span between two posts in the longitudinal direction)

So we need a total of 10 planks of the above mentioned dimensions for the span of 10.0

Weight of a plank

Weight of all 10 planks

Load from planks on frame

Total load from the surface cover on either

sides

So load per unit length

Total load acting on the frame from wind, snow and sheathing load
$=53.0 * 12.0 i * 2.0 i * 84.0 i /(12 * 12 *$ 12)

$$
=60.667 \text { 와 }
$$

$=60.667 * 10=606.67$

$=610 /(6.5 * 10)=9.384$

$=1220$ erspan of 10.0

$=1220.0$ 10.0 122.0 .

$=902$ ?2.

$=0.902$

\subsubsection{Design of frame}

Longitudinal members along the length

Spacing

$$
=\frac{\mathrm{D.0}}{2.0}=2.8
$$

Load on each purlin from top

$$
=69.384 * 2.8=194.275
$$


Moment

$$
\begin{aligned}
& =\frac{\hat{P Q}}{8}=\frac{194.275 * 10 * 10}{8} \\
& =7.478 .4 .37 \text { 스 }
\end{aligned}
$$

Now we have to select sections which match the above obtained moment: 22.8750 .188

Take 4 no's of $P$ ? 2.8750 .188 where 2 are placed on either sides

Nominal weight of $2 ? 2.875 \geqslant 0.188$

$$
=5.4 \text { QP? }
$$

Take 1 no's of ??3.5? 0.216 (center top)

Nominal weight of $2 ? 3.5 \geqslant 0.216$

$$
=7.58 \text { ㅇ? }
$$

Lateral members design

Loads on to lateral/transverse members

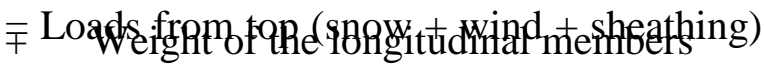

$$
\begin{aligned}
& \text { 千0992384 ??? + (5.4*10)*2 + (7.58* } \\
& =4509.96 \text { ? } 145.9 \text { ? }
\end{aligned}
$$

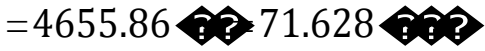

Spacing of these lateral members

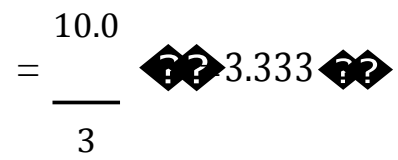

Load to be carried by one rafter

$$
\begin{aligned}
& =71.628 \text { ? } 3.333=238.736 \\
& =\frac{238.736 * 6.5 * 6.5}{8}=\frac{8}{8} \\
& =1260874 \text { AD }
\end{aligned}
$$

Take 4 no's ? $1.900>0.188$ on one sloped side

Self-weight of ???1.900 0.188

$$
=3.44 \text { ใ? }
$$

\subsubsection{Design Posts}

Posts are designed for the loads from the sloped surface as well the members of frame with 
spacing of 10.0 
Total load acting on one side of posts

$$
\begin{aligned}
& =4655.86 ?+(3.44 * 6.5) * 4=4745.3 ? \\
& =4745.3 / 10.0=474.53 \text { ?? } \\
& =\frac{8}{8}=\frac{474.53 * 10 * 10}{8} \\
& =5931.625 \\
& =5021 \text { ?? } \\
& =0.5 * 8.0 ? ?=4.0
\end{aligned}
$$$$
\text { Load per unit length }
$$

Consider slenderness ratio $2 ? \mathrm{P}$

Consider $22.25 * 2.25 * 0.233$ from steel manual

Self-weight of $2 ? 2.25 * 2.25 * 0.233$

$$
\begin{aligned}
& =6.26 \text { ?? } \\
& =8.0 ? ?
\end{aligned}
$$

HSS $2.25 * 2.25 * 0.233$ can take an axial compression load of

$$
=56.7 ?
$$

\section{Summary of loads:}

Total load of $0.393 \mathrm{kip} / \mathrm{ft}$. is the contribution of wind and snow loads on the deck

Table 6.3: Summary of loads coming on to the deck from canopy

\begin{tabular}{|c|c|c|c|c|}
\hline Element considered & Factor & $\begin{array}{c}\text { Load } \\
\text { Distributi } \\
\text { on } \\
\text { (lb/ft.) }\end{array}$ & $\begin{array}{c}\text { Factored } \\
\text { Load } \\
\text { Distributio } \\
\text { n (lb/ft.) }\end{array}$ & $\begin{array}{c}\text { Total } \\
\text { Weight } \\
\text { (lb/ft.) }\end{array}$ \\
\hline Deck weight & - & & 170.0 & \\
\hline Railing over the deck & - & & 45.0 & 215 \\
\hline $\begin{array}{c}\text { Self-weight of the deck (from the assumed } \\
\text { dimensions) }\end{array}$ & - & & 57.0 & 272 \\
\hline Dead load of wear surface, & - & & 112.5 & 384.5 \\
\hline Dead load of deck based on tributary width & - & & 75.0 & 459.5 \\
\hline Uniform lane load & - & & 160.0 & 619.5 \\
\hline Pedestrian load & 1.75 & 850 & 1490.0 & 2109.5 \\
\hline Equestrian load & 1.70 & 595 & 1011.5 & 3121 \\
\hline Snow load per unit length & - & & 250.0 & 3371 \\
\hline
\end{tabular}




\begin{tabular}{|c|c|c|c|c|}
\hline Exposed deck on wind ward side & - & - & 18.7 & 3389.7 \\
\hline Vertical railing & - & - & 16.5 & 3406.2 \\
\hline Horizontal railing & - & - & 8.12 & 3414.3 \\
& & & & 2 \\
\hline Wind load acting on the moving vehicle & - & - & 100 & 3514.3 \\
& & & & 2 \\
\hline Canopy Design & - & - & 455 & 3969.3 \\
\hline Wind load (Wind ward and Leeward) & - & - & & 2 \\
\hline Snow load ( Wind ward and Leeward)) & - & - & 325 & 4294.3 \\
\hline Self-weight of roof covering & - & - & 122 & 4416.3 \\
& - & - & 29.18 & 4445.5 \\
\hline Self-weight of Rafters & - & - & 27.52 & 4473.0 \\
& - & - & & 2 \\
\hline Self-weight of lateral Rafters (6.5 ft. long) & - & - & 50.08 & 4523.1 \\
\hline Super Structure & - & & \\
\hline Posts (8.0 ft. long) & - & & & \\
\hline
\end{tabular}

\subsubsection{Check for Load bearing Capacity of the Deck}

Taking visually graded Dimension lumber, Structural Douglas Fir Larch type of dimensions $3 i$

$\mathrm{x} 10 i$

Shear stress of the wooden plank =625

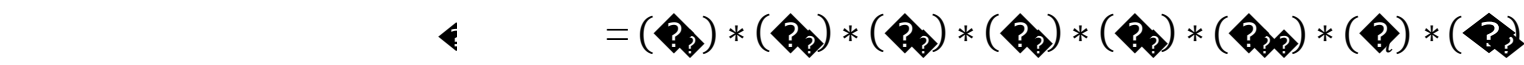

Adjusted bending stress

$$
=1500 * 1.0 * 1.0 * 1.0 * 1.1 * 1.2 * 1.0 * 1.0
$$$$
=1980.0 \text { - }=285
$$

Bending moment is =

Actual Load on to the deck

So safe in bending stress

$$
=\frac{615.41}{(12.04 / 1.25)}
$$

$$
=65.32 \text { P }<216
$$




\subsection{Design of Longitudinal Stringers}

Total weight onto the deck from top covering

Load per unit length

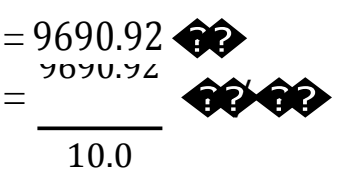

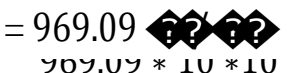

Moment due to load onto deck (excluding deck weight)

Moment in the timber deck

$$
=
$$

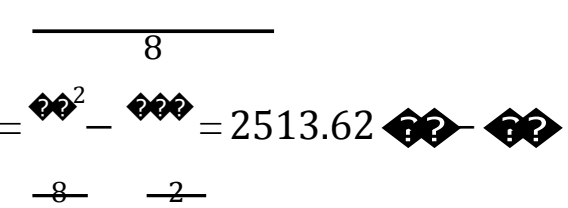

$$
=2.51
$$

Load on the girder from top covering

Load per unit length

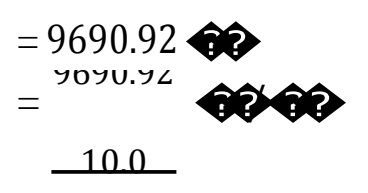

Moment on the girder

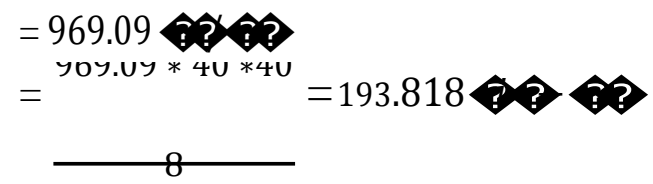

Design Bending moment for girder

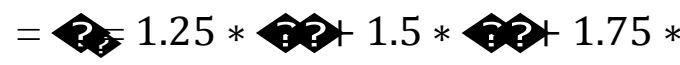

$$
\begin{aligned}
& =1.25 *\left(\mathrm{M}_{\text {self }}+\mathrm{M}_{\text {guard rail }}+\mathrm{M}_{\text {wind on moving vehicle }}+\mathrm{M}_{\text {top covering }}\right)+1.5 *\left(\mathrm{M}_{\mathrm{DW}}\right) \\
& +1.75 *\left(\mathrm{M}_{\mathrm{vehicle}}+\text { Pane loading }+\mathrm{M}_{\text {pedestrian }}\right) *(?) \\
& =1.25 *(11.4+15.0+7.879+3.428+8.4+12.11+193.818+50.0)+1.5 * \\
& (22.5)+1.75 *(86.49+77.0+298.0) *(0.60) \\
& =373.22+33.75+484.564 \\
& =891.536 \text { ? }
\end{aligned}
$$

From Steel Manual select an appropriate W-Section:

From the above available bending moment select 119 which has bending moment

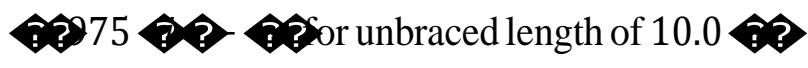


Taking self-weight of the girder

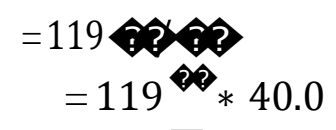

Bending moment due to self-weight of the girder

$$
\begin{aligned}
& =119 \text { P? } 40.0 * 40.0 / 8 \\
& =23800 \text { ?? } \\
& =23.8 \text { ?? }
\end{aligned}
$$

Modified Bending Moment

$=891.536 ? ?-? ?+1.25 *(23.8$

$=921.28 ? ? ?$

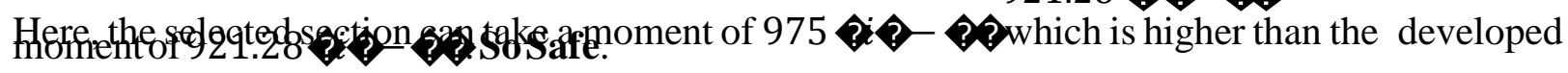
Summary of Loads from all the elements:

Table 6.4: Summary of all the loads including deck and stringer self-weight

\begin{tabular}{|c|c|c|c|c|}
\hline Element considered & Factor & $\begin{array}{c}\text { Load } \\
\text { Distributi } \\
\text { on } \\
\text { (lb/ft.) }\end{array}$ & $\begin{array}{c}\text { Factored } \\
\text { Load } \\
\text { Distributio } \\
\text { n (lb/ft.) }\end{array}$ & $\begin{array}{c}\text { Total } \\
\text { Weight } \\
\text { (lb/ft.) }\end{array}$ \\
\hline Deck weight & - & & 170.0 & \\
\hline Railing over the deck & - & & 45.0 & 215 \\
\hline $\begin{array}{c}\text { Self-weight of the deck (from the assumed } \\
\text { dimensions) }\end{array}$ & - & & 57.0 & \\
\hline Dead load of wear surface, & - & & 112.5 & 384.5 \\
\hline Dead load of deck based on tributary width & - & & 75.0 & 459.5 \\
\hline Uniform lane load & - & & 160.0 & 619.5 \\
\hline Pedestrian load & 1.75 & 850 & 1490.0 & 2109.5 \\
\hline Equestrian load & 1.70 & 595 & 1011.5 & 3121 \\
\hline
\end{tabular}




\begin{tabular}{|c|c|c|c|c|}
\hline Snow load per unit length & - & & 250.0 & 3371 \\
\hline Exposed deck on wind ward side & - & - & 18.7 & 3389.7 \\
\hline Vertical railing & - & - & 16.5 & 3406.2 \\
\hline Horizontal railing & - & - & 8.12 & 3414.3 \\
\hline Wind load acting on the moving vehicle & - & - & 100 & 3514.3 \\
\hline Canopy Design & & & & 2 \\
\hline Wind load (Wind ward and Leeward) & - & - & 455 & 3969.3 \\
\hline Snow load ( Wind ward and Leeward)) & - & - & 325 & 4294.3 \\
\hline Self-weight of roof covering & - & - & 122 & 4416.3 \\
\hline Self-weight of Rafters & - & & & 2 \\
\hline Self-weight of lateral Rafters (6.5 ft. long) & - & - & 27.52 & 4473.0 \\
\hline Super Structure & - & - & & 2 \\
\hline Posts (8.0 ft. long) & - & - & 50.08 & 4523.1 \\
\hline Deck self-weight & - & & & 4605.6 \\
\hline Total Load from all the elements & - & & & 4724.6 \\
\hline & - & & & 4724.6 \\
\hline
\end{tabular}

\subsection{Design of Lateral bracing}

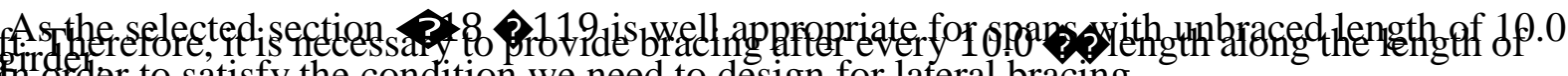
mrorder to satisfy the condition we need to design for lateral bracing.

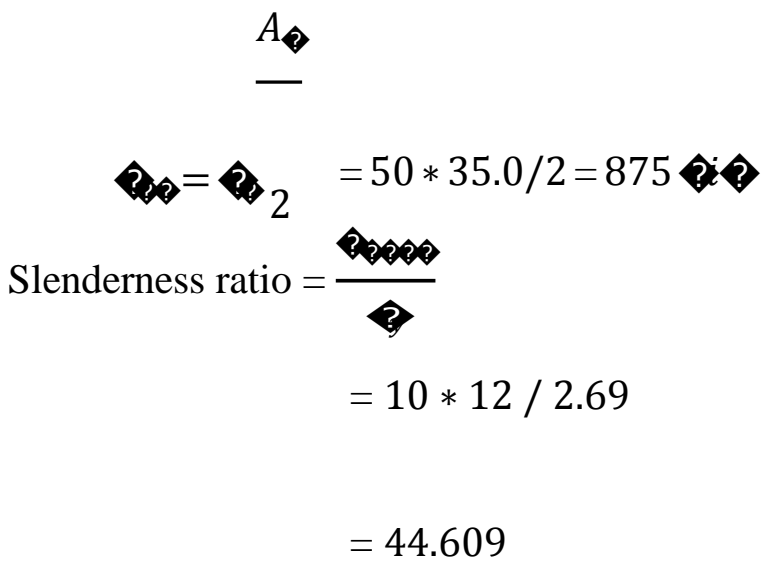




$$
\beta=3
$$

$$
\begin{aligned}
\text { Required Area bracing }= & 2 * \beta * \Pi^{2} * A \\
= & 2 * 3 *(3.14)^{2} *(35 / 2) /(44.609)^{2} \\
& =0.520 i^{2} \\
\operatorname{Min~} \mathrm{r}_{\mathrm{y}} & =\frac{\diamond}{200} \\
& =\frac{4.5 * 12.0}{200}
\end{aligned}
$$

Select $C x>$ with $\geq 0.27(-0.457)=0.27$

Check stiffness:

$$
\begin{aligned}
& \mathrm{K}_{\text {ideal }}=3 * 875 /(10 * 12) \\
& =21.875 \text { is } / i \text {. }
\end{aligned}
$$

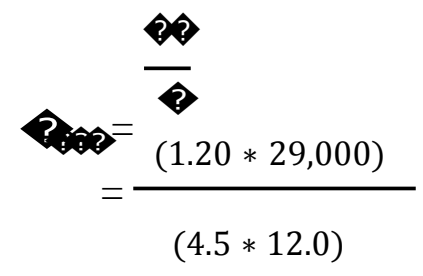

Check strength of brace $=\begin{gathered}\mathrm{L}_{\text {brace }} \\ =644.44\end{gathered}$

$$
\begin{aligned}
= & \frac{4.5 * 12}{0.457} \\
= & 118.161 \\
= &
\end{aligned}
$$

For $>1.5$

$$
\begin{aligned}
\mathrm{F}_{\mathrm{cr}} & =\left(0.877 / / \mathrm{F}_{\mathrm{y}}\right. \\
& =\left(0.877 /(1.562)^{2}\right) * 50 \\
& =17.972
\end{aligned}
$$


7.

9

7

2

1.

3

8 


$$
\begin{aligned}
= & 24.80 \\
\text { Required } & =0.004 \beta \\
& =0.004 * 3 * 875 \\
= & 10.5
\end{aligned}
$$

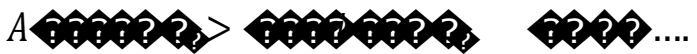

\subsection{Shear Analysis}

Shear is usually evaluated at a distance from the support equal to depth of the member Shear load from wearing surface (internal stringer)

$$
\begin{aligned}
& \left(\frac{-}{2}-\right. \\
& =112.5 *\left(\frac{40.0}{2}-\frac{19.0}{12}\right)
\end{aligned}
$$

Shear load from wearing surface (external stringer)

$$
\begin{aligned}
& =2071.87 \\
& =69.44 *\left(\frac{40.0}{2}-\frac{19.0}{12}\right)
\end{aligned}
$$

Shear load from deck (interior stringer)

$$
=1278.85 \text { ㅇ? }
$$

$$
\begin{aligned}
& (2) \\
& \overline{2}-\vartheta \\
= & 75.0 *\left(\frac{40.0}{2}-\frac{19.0}{12}\right)
\end{aligned}
$$

Shear load from deck (exterior stringer)

$$
=1381.25 \text { 요 }
$$

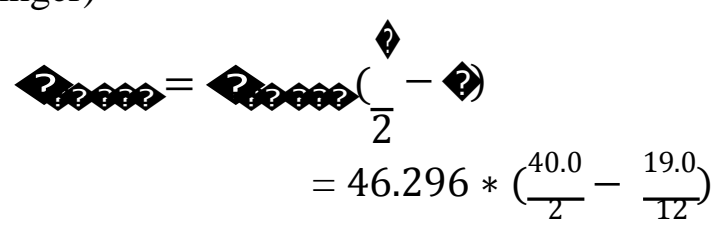

Shear due to guardrail on external girder

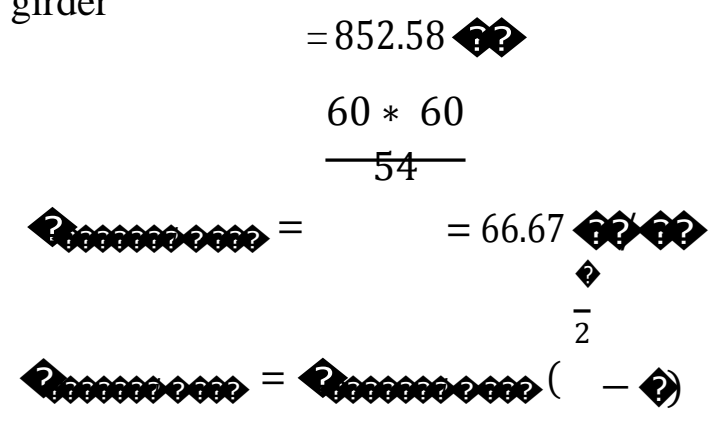




$$
\begin{aligned}
& \left.=66.67 * \frac{(20.0}{2}-\frac{19.0}{2}\right) \\
& =1227.73
\end{aligned}
$$

Shear due to self-weight of the girder

$$
\begin{aligned}
= & \left(\frac{1}{2}-\hat{\theta}\right) \\
& =119 *\left(\frac{40.0}{2}-\frac{19.0}{2}\right)
\end{aligned}
$$

Shear due to moving vehicle on the external girder 12.0

$$
=2191.50
$$

Shear due to top covering

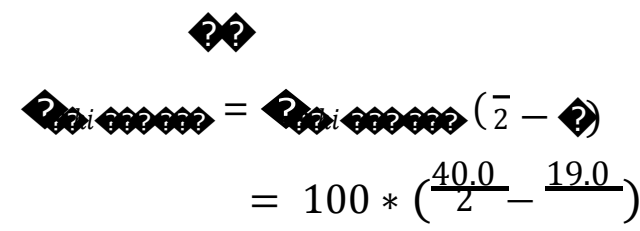

$x\left(\frac{40.0}{2}-\frac{19.0}{12.0}\right)$

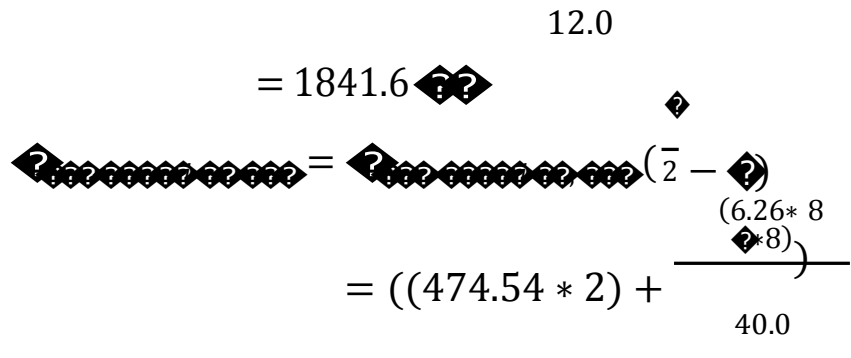

$$
=
$$

\subsection{1 ?}

\section{Positioning of design vehicle for maximum shear:}

Design vehicle must be placed such that maximum shear is produced with an axle at a distance from the support equal to the lesser of either 3 times the depth, $3 \mathrm{~d}$ of the girder or one quarter of the span

support)

$$
\begin{aligned}
& 3 * \vartheta=\frac{3 * 19.0}{2}=4.75 \\
& ={ }^{40.0} \stackrel{12.0}{=} 10.0 ? \quad \text { (Distance of the axle from the }
\end{aligned}
$$

$$
4 \quad 4
$$

The design vehicle is placed on the deck where the axle is at a distance of 4.75 ? from the support 


\section{S-F Diagram}

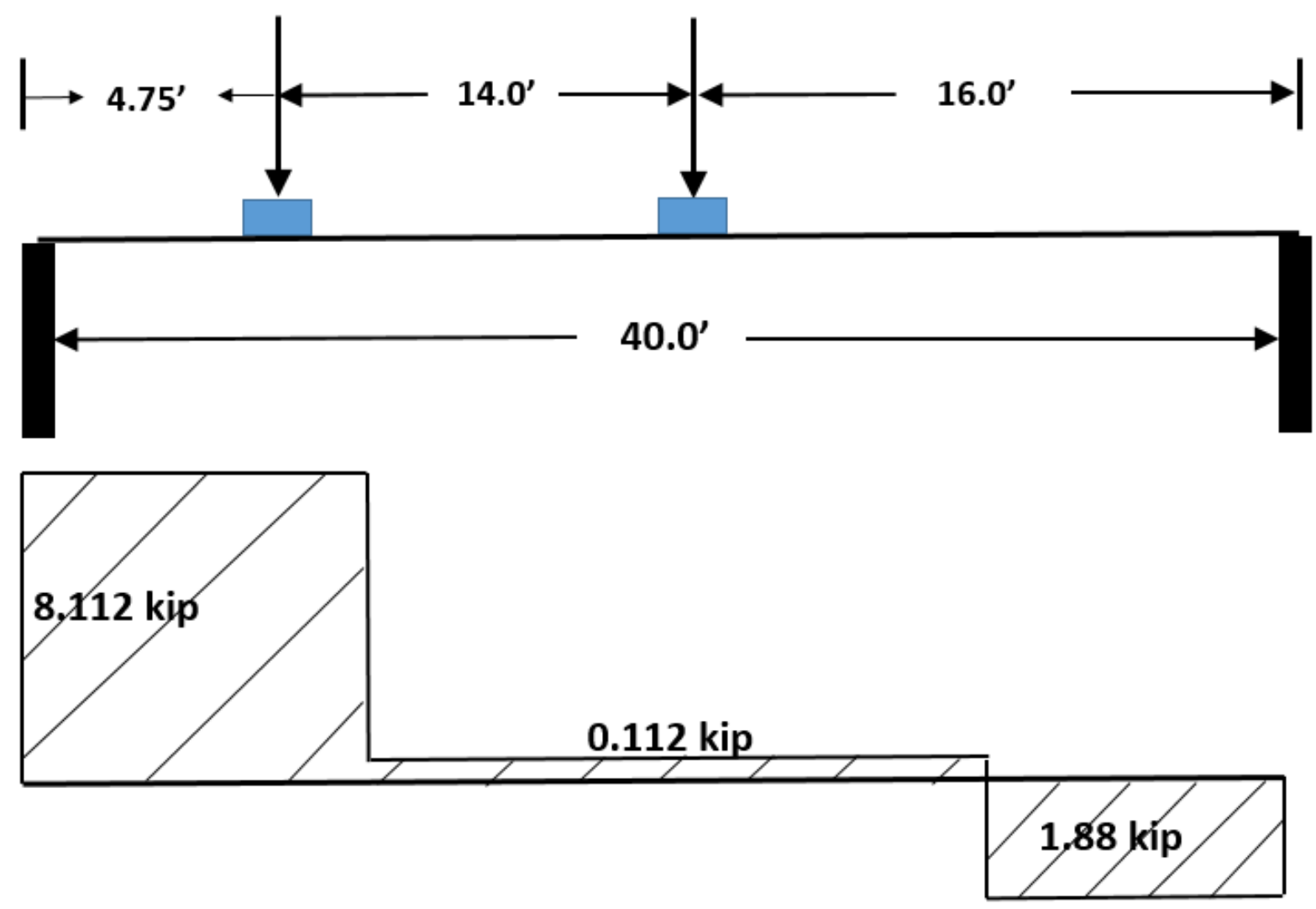

Figure 6.8: Shear force diagram showing positioning of load to obtain maximum shear

Shear due to moving vehicle on the external girder

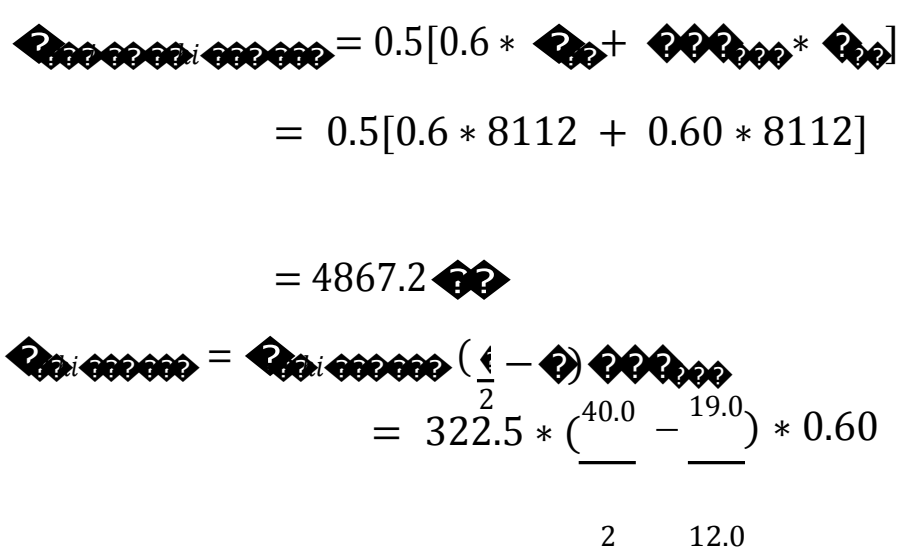




$$
=3563.625
$$

Shear due to pedestrian loading

$$
\begin{aligned}
& \Delta=(1-2)(2) \\
& \left.=1490 \gg \frac{(40.0}{2}-\frac{19.0}{12.0}\right)>0.60 \\
& =16464.50
\end{aligned}
$$

Factored Shear

$$
0=1.250+1.50+1.75
$$

1. $1.5[+$

$2191.5+$

$1.75[4867.2+$
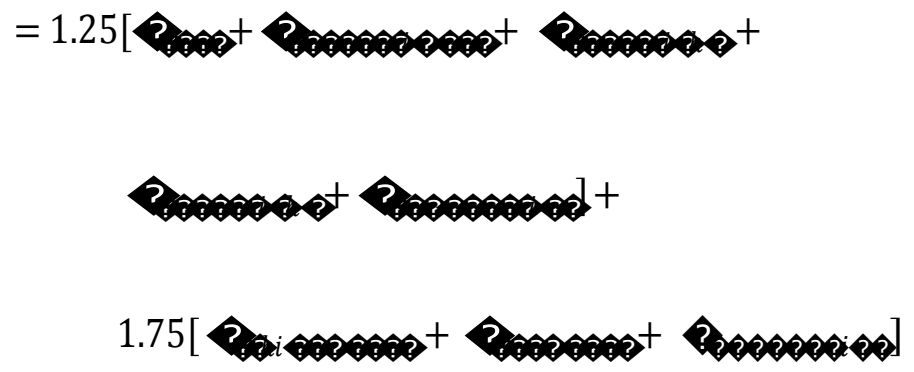

$=1.25[1381.25+1227.3+852.58+1841.6+$ $17662.71]+\quad 1.5[2071.8+1278.85]+$ $3563.625+16464.50]$

$=31446.17+5025.97+=78661.363$

$=78661.363$

\subsection{Serviceability Check on the Bridge Deck}

For spans other than cantilever arms, the deflection of the bridge due to the un-factored pedestrian live loading shall not exceed 1/360 of the span length. Deflection in cantilever arms due to the 
pedestrian live loading shall not exceed1/220 of the cantilever length. Horizontal deflections under un-factored wind loading shall not exceed 1/360 of the span length.

Allowable deflection for vehicular loads shall not exceed $/ 800$. Allowable deflection for bedestrian and yehigular load is

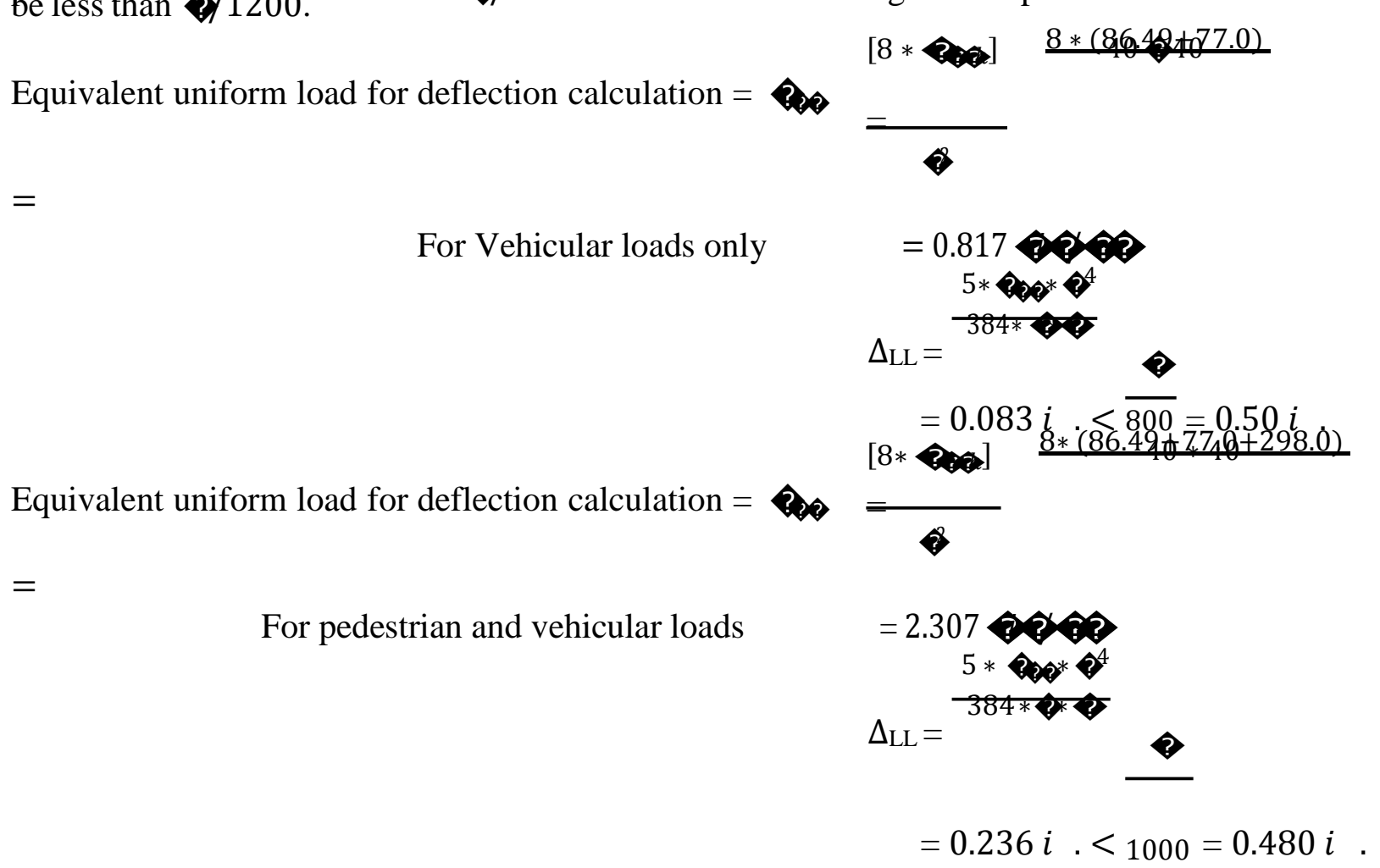

Summary of Loads considered in the Design:

\begin{tabular}{|c|c|c|c|c|}
\hline Element considered & Factor & $\begin{array}{c}\text { Load } \\
\text { Distributi } \\
\text { on } \\
(\mathbf{l b / f t} .)\end{array}$ & $\begin{array}{c}\text { Factored } \\
\text { Load } \\
\text { Distributio } \\
\mathbf{n}(\mathbf{l b} / \mathbf{f t} .)\end{array}$ & $\begin{array}{c}\text { Total } \\
\text { Weight } \\
(\mathbf{l b} / \mathbf{f t} \text {. })\end{array}$ \\
\hline Deck weight & - & & 170.0 & \\
\hline $\begin{array}{c}\text { Railing over the deck } \\
\text { Self-weight of the deck (from the assumed } \\
\text { dimensions) }\end{array}$ & - & & 45.0 & 215 \\
\hline Dead load of wear surface, & - & & 57.0 & \\
\hline Dead load of deck based on tributary width & - & & 112.5 & 384.5 \\
\hline Uniform lane load & - & & 75.0 & 459.5 \\
\hline Pedestrian load & 1.75 & 850 & 1490.0 & 2109.5 \\
\hline Equestrian load & 1.70 & 595 & 1011.5 & 3121 \\
\hline
\end{tabular}




\begin{tabular}{|c|c|c|c|c|}
\hline Snow load per unit length & - & & 250.0 & 3371 \\
\hline Exposed deck on wind ward side & - & - & 18.7 & 3389.7 \\
\hline Vertical railing & - & - & 16.5 & 3406.2 \\
\hline Horizontal railing & - & - & 8.12 & 3414.3 \\
\hline Wind load acting on the moving vehicle & - & - & 100 & 3514.3 \\
\hline Canopy Design & & & & 2 \\
\hline Wind load (Wind ward and Leeward) & - & - & 455 & 3969.3 \\
\hline Snow load ( Wind ward and Leeward)) & - & - & 325 & 4294.3 \\
\hline Self-weight of roof covering & - & - & 122 & 4416.3 \\
\hline Self-weight of Rafters & - & - & & 2 \\
\hline Self-weight of lateral Rafters (6.5 ft. long) & - & - & 27.52 & 4473.0 \\
\hline Super Structure & - & - & & 2 \\
\hline Posts (8.0 ft. long) & - & - & 50.08 & 4523.1 \\
\hline Total Load from all the element & - & - & & 4642.1 \\
\hline & - & & & \\
\hline & - & & & \\
\hline
\end{tabular}

\subsection{Alternate Design of Timber/Glulam Stringers for Steel Stringers}

\begin{tabular}{|l|l|}
\hline $\begin{array}{l}\text { Total factored moment on to the stringer from } \\
\text { all the bridge elements is }\end{array}$ & $=8$ \\
\hline $\begin{array}{l}\text { Assuming three glulam sections to resist the } \\
\text { moment, the moment resisted by the central } \\
\text { stringer is the maximum }\end{array}$ & $=445.77$ \\
\hline Consider a Glulam Section 24 \\
\hline $\begin{array}{l}\text { The maximum bending strength of the glulam } \\
\text { section as per NDS supplement }\end{array}$
\end{tabular}




\begin{tabular}{l} 
From NDS supplement, select $10_{\overline{2}} \times 38_{\overline{2}}$ section with sectional modulus of $2594 i^{>}>$ \\
$2228.9 i^{3}$ \\
\hline So Safe.
\end{tabular}




\section{References}

1. A.C. Manalo., T. A. (2010). Flexural Behaviour of Glue-Laminated Fibre Composite Sandwich Beams. Composite Structures Vol. 92, 2703-2711.

2. A.C. Manalo., T. A. (2013). Shear Behaviour of Glued Structural Fibre Composite Sandwich Beams. Construction and Building Materials Vol.47, 1317-1327.

3. AASHTO. (2009). LRFD Bridge design specification for pedestrian bridges. NCHRP.

4. AASHTO. (2012). AASHTO LRFD Bridge Design Specifications. Washington D.C.

5. AASHTO. (2012). LRFD Bridge Design Specifications. Washington D.C.

6. Ahmad, Y. (2010). Thesis: Bending Behavior of Timber Beams Strengthened Using Fiber Reinforced Polymer Bars and Plates. Universiti Teknologi Malasia.

7. Aixi Zhou., T. K. (2005). Joining techniques for fiber reinforced polymer composite bridge deck systems. Composite Structures 69 , 336-345.

8. Alann, A. R. ( 2009). Strengthening of Timber Beams Using FRP With Emphasis On Compressive Strength: A State Of The Art Review. International Conference of International Institute for FRP in Construction for Asia-Pacific Region.

9. Ambrose, J. (1993). Building Structures. New York: John Wiley \& Sons.

10. Bank, L. C. ( 2006). Application of FRP Composites to Bridges in the USA ,. Proceedings of the International Colloquium on Application of FRP to Bridges, (pp. 9-16). Tokyo, JAPAN: Japan Society of Civil Engineers (JSCE).

11. Bonacci, J. (1996). Strength, Failure Mode and Deformability of Concrete Beams Strengthened Externally with Advanced Composites. Proceedings of the 2nd International 
Symposium on Advanced Composite Materials in Bridges and Structures. Montreal, Canada.

12. D. Svecova., R. E. (2004). Flexural and Shear Strengthening of Timber Beams Using Glass Fibre Reinforced Polymer Bars — An Experimental Investigation. Journal of Civil Engineering, Vol. 31, 45-55.

13. Davalos, J. F. (2000). Development of an innovative connector system for fiber reinforced polymer bridge decks to steel stringers . Washington, DC: NCHRP-IDEA Project 66, National Cooperative Highway Research Program, .

14. Dostal, C. (1990). Engineered materials handbook: adhesives and sealants, Vol III. Materials Park: ASM International Handbook Committee.

15. Ehlen, M. (1999). Life-Cycle Costs of Fiber-Reinforced-Polymer Bridge Decks. . Journal of Materials in Civil Engineering , 224-232.

16. Elizabeth S. Roland., M. L. (2005). Design and demonstration of a dynamometric horseshoe for measuring ground reactionloads of horses during racing conditions. Journal of Biomechanics Vol.38, 2102-2112.

17. Gary M. Raftery., A. M. (2009). Bonding of FRP materials to wood using thin epoxy gluelines. International Journal of Adhesion \& Adhesives Vol.29 , 580-588.

18. Gerriste, A. S. (1986). Prestressing with Aramid Tendons,. Proceedings of 10th FIP Congress. New Delhi,.

19. Hamid Saadatmanesh., M. R. (November, 1991). RC Beams Strengthened With GFRP Plates: Experimental Study. Journal of Structural Engineering Vol. 117 (11), 3417-3433.

20. Hans, J. B. (2011). Ductility aspects of reinforced and non-reinforced timber joints. Engineering Structures Vol. 33, 3018-3026. 
21. Husam Najm., J. S. (2007). Compression Tests of Circular Timber Column Confined with Carbon Fibers Using Inorganic Matrix. Journal of Materials in Civil Engineering, Vol. 19(2), 198-204.

22. K.U. Schober., K. R. (2005). Experimental Invesigation on Flexural Strengthening of Timber Structures With FRP. Proceedings of the International Symposium on Bond Behaviour of FRP in Structures (pp. 457-464). International Institute for FRP.

23. Kei Sawata. (2015). Strength of bolted timber joints subjected to lateral force. Journal for Wood Sciences Vol.61, 221-229.

24. Kings HB., Q. M. (1978 ). A laboratory system for production of flexion rates and forces in the forelimb of the horse. American journal of veterinary research, Vol. 39(3), 365-369.

25. Kun Ho Eugene Kim., B. A. (2016). Compression Behavior of FRP Strengthened Bridge Timber Piles Subjected to Accelerated Aging. Construction and Building Materials Vol.124, 177-185.

26. Martin Schafers., W. S. (2010). Development of adhesive bonded Timber-UHPC Comosites Experimental and theoretical investigations. Wood Conference on Timber. Germany.

27. Mohammad Derikvand., H. P. (2016). A modified method for shear strength measurement of adhesive bond in solid wood. Bioresources Vol.11 (1), 354-364.

28. Mohammad, R. A. (2008). Debonding failure modes of flexural FRP-strengthened RC beam. Composites: Part B Vol 39, 826-841.

29. Moon, F. L. (2002). Shear stud connections for the development of composite action between steel girders and fiber-reinforced polymer decks. Journal for Structural Engineering Vol. 128(6), 762-770. 
30. Pellegrino, C., Tinazzi, D., \& Modena, C. (2008). Experimental Study on Bond Behavior between Concrete and FRP Reinforcement. Journal of Composite for Construction Vol.12(2), 180-189.

31. Petrie, E. (2000). Handbook of adhesives and sealant. . New York: McGraw-Hill.

32. Rami H. Haddad., R. Z.-R. (2016). An anchorage system for CFRP strips bonded to thermally shocked concrete. International Journal of Adhesion \& Adhesives Vol. 71, 1022.

33. Ritter, M. A. (1990). Timber Bridges Design, Construction, Inspection, and Maintenance. United States Department of Agriculture Forest Services.

34. Sahirman, S. C. (2003). Evaluation of the Economic Feasibility of Fiber-Reinforced Polymer (FRP) Bridge Decks. ISPA/SCEA International Joint Conference Annual Meeting. Orlando.

35. Sahirman, S., Creese, R. C., GangaRao, H. V., \& Brown, C. (2003). Economic Analysis of Fiber Reinforced Polymer (FRP) Bridge Decks. IIE Annual Conference Proceedings, (pp. $1-6)$.

36. Samuel, J. R. (1914). The Mechanical Properties of Wood. Yale University Newhaven, CT: John Wiley\& Sons, Inc.

37. Selbo., M. L. (1975). ADHESIVE BONDING OF WOOD. Forest Product LaboratoryForest Service.

38. SONG Xiaobin1., T. H. (2010). Compressive Stress Strain Relationship of Wood Confined with Fiber Composite Sheets. Advanced Materials Research Vols. 133-134, 1207-1211. 
39. Stergios Adamopoulos., A. B.-G. (2012). Adhesive bonding of beech wood modified with a phenol formaldehyde compound. Europe. Journal for Wood and Wood Products Vol.70, 897-901.

40. Tanaka, H. (2006). A case study on life-cycle assessment of environmental aspect of FRP structures. Third international conference on FRP composites in civil engineering (CICE). Miami, Florida, USA;

41. Thanasis C. Triantafillou., N. D. (1992 ). Pre-stressed FRP Sheets as External Reinforcement of Wood Members. Journal of Structural Engineering, 1270-1284.

42. Thansis., T. C. (May 1997). Shear Reinforcement of wood using FRP materials. Journal of Materials in Civil Engg Vol. 9(2), 65-69.

43. Thomas Keller., H. G. (2005). Quasi-static and fatigue performance of a cellular FRP bridge deck adhesively bonded to steel girders. Composite Structures Vol. 70, 484-496.

44. Tim J. Davisu., P. A. (2000). Bolted joints in glulam and structural timber composites. Construction and Building Materials Vol.14 , 407 - 417.

45. Tobias Zetterberg., B. T. (2001). On design of joints between composite profiles for bridge deck applications. Composite Structures 51, 83-91.

46. Triantafillou., P. N. (1992). Post Strengthening of R/C Beams with Epoxy Bonded Fiber Composite Materials. ASCE Specialty conf. on Advanced Composites for Civil Engg Structures, (pp. 245-256).

47. Valbona, M., \& Reza, H. P. (2014). Bridge decks of fibre reinforced polymer (FRP): A sustainable solution. Construction and Building Materials Vol 50, 190-199. 
48. Weiping Zhang., X. S. (2012). Compressive Behavior of Longitudinally Cracked Timber Columns Retrofitted Using FRP Sheets. Journal of Structural Engineering, Vol. 138(1), 90-98.

49. Williamson, T. (2002). "APA Engineered Wood Handbook". USA: McGraw-Hill.

50. Zhenhua Wu., A. M. (2009). Flexural behavior of prestressed FRP tubular bridge deck. Composites: Part B Vol 39, 125-133. 
